Nordiska ministerrådet

Ved Stranden 18

DK-1061 København K

www.norden.org

NORDISKE ARBEJDSPAPIRER

NOR D I S K A ARBETSPAPPER

\title{
Nordiska ministerrådet - Budgetförslag
}

Planer och Budget 2016

http://dx.doi.org/10.6027/NA2015-912

NA2015:912

ISSN 2311-0562

Detta arbetspapper är utgivet med finansiellt stöd från 

Nordiska ministerrådet - Budgetförslag

\section{Planer och Budget 2016}

Framlagt av Generalsekreteraren 


\section{Indholdsfortegnelse}

Forord $\quad 9$

$\begin{array}{lr}\text { Læsevejledning } & 10\end{array}$

Den totale udgiftsramme for Nordisk Ministerråds budget for virksomhedsåret $2016 \quad 12$

Budgettets fordeling på budgetpostkategorier $\quad 13$

Økonomiske og politiske frihedsgrader i Nordisk Ministerråds budget 14

$\begin{array}{lr}\text { Nordisk Ministerråds planer for virksomhedsåret } 2016 & 16\end{array}$

Hovedlinjerne i budget $2016 \quad 16$

Hovedlinjer i Nordisk Ministerråds politiske prioriteringer $2016 \quad 16$

$\begin{array}{lr}\text { Samarbetsministrarna } & 18\end{array}$

$\begin{array}{ll}\text { Generel Indledning } & 18\end{array}$

$\begin{array}{ll}\text { Prioriteringsbudget } & 21\end{array}$

$\begin{array}{ll}\text { Formandskabsdelen } & 21\end{array}$

Danmarks formandskabspulje $\quad 22$

1-8008 Vækst $\quad 22$

1-8009 Velfærd 23

1-8010 Værdier $\quad 24$

1-8011 Det blå Arktis $\quad 25$

Islands formandskabspulje $\quad 26$

1-8005 Den nordiska spellistan $\quad 26$

1-8006 Välfärdsvakten $\quad 27$

1-8007 Bioekonomi-initiativet $\quad 28$

Sveriges formandskabspulje $\quad 29$

1-8001 NordMin 29

1-8003 Förbättrade emissionsinventeringar av kortlivade klimatpåverkande luftföroreningar30

1-8004 Læring på arbeidsplass (LPA) 30

Øvrig del af prioriteringsbudgettet

1-8110 Testcenter $\quad 31$

1-8111 Uddannelse og forskning inden for grøn vækst 32

1-8112 Elmarknaden $\quad 33$

1-8113 Grønne tekniske normer og standarder - Norden som standardmaker $\quad 34$

1-8114 Grønt offentligt indkøb 35

1-8115 Utveckla tekniker och metoder för avfallshantering 36

1-8116 Främja integration av miljö och klimat i utvecklingssamarbetet 38

1-8118 Särskilda prioriteringer Grön tillväxt 39

1-8210 Hållbar nordisk välfärd $\quad 40$

1-8212 Välfärd och kost $\quad 41$

1-8310 Klimavenligt byggeri $\quad 41$

1-8311 Kultur og kreativitet - KreaNord initiativet $\quad 42$

1-8312 Offentligt-privat-partnerskab om planteforædling i Norden 42

1-8313 Ny Nordisk Mad $\quad 43$

1-8410 Politiska prioriteringar $\quad 44$

1-8411 Politiske initiativer i nærområderne $\quad 44$

1-8420 Profilering og positionering $\quad 45$

1-8510 Nye tværgående initiativer 46

Nordisk ministerråds fællesaktiviteter og Sekretariatet 48

1-0410 Föreningarna Nordens Förbund $\quad 48$

1-0425 Bidrag til Grønland $\quad 49$ 
1-0435 Generalsekreterarens disponeringsreserv $\quad 49$

1-0460 Hållbart Norden $\quad 50$

1-1011 Informationsaktiviteter $\quad 51$

1-1012 Norden i Fokus $\quad 52$

1-1030 Hallo Norden $\quad 53$

1-1036 Grænsehindringsråd $\quad 54$

1-1050 Tjänstemannautbyte $\quad 55$

1-0180 Ministerrådets sekretariat (NMRS) 56

$\begin{array}{ll}\text { Internationalt samarbejde } & 57\end{array}$

1-0820 Kunskapsuppbyggning och nätverk $\quad 57$

1-0980 Partnerskap och gränsregionalt samarbete $\quad 58$

1-0960 NGO-verksamhet i Östersjöregionen $\quad 59$

1-0970 Ministerrådets kontor i nordvästra Ryssland $\quad 60$

1-0810 Ministerrådets kontorer i Estland, Letland, Litauen og Nordvestrusland 61

1-0850 Internationellt samarbete $\quad 62$

1-0870 Arktiskt samarbetsprogram $\quad 63$

1-0950 Hvideruslandsaktiviteter $\quad 64$

1-0990 Samarbetet med Nordens grannar i Väst 65

$\begin{array}{lr}\text { Uddannelse og forskning } & 66\end{array}$

$\begin{array}{ll}\text { Generel indledning } & 66\end{array}$

Generelle forsknings- og uddannelsesindsatser $\quad 69$

2-2505 Dispositionsmidler Uddannelse og forskning 69

$\begin{array}{ll}\text { Politikudvikling } & 70\end{array}$

2-2560 Ad hoc arbejdsgrupper på prioriterede områder $\quad 70$

2-2544 Det nordiske sprogsamarbejde $\quad 71$

2-2553 Politikudvikling, Videnssamfund og IT-infrastruktur $\quad 72$

2-3127 Politikudvikling voksnes læring $\quad 73$

$\begin{array}{ll}\text { Mobilitets- og Netværksprogrammer } & 74\end{array}$

$\begin{array}{ll}\text { 2-2513 Nordplus } & 74\end{array}$

2-2515 Nordic Master Programme $\quad 76$

2-3100 NordForsk $\quad 76$

$\begin{array}{ll}\text { Forskning i øvrigt } & 78\end{array}$

2-3180 Nordisk Institut for Teoretisk Fysik (NORDITA) 78

2-3181 Nordisk Institutt for sjørett (NIfS) $\quad 79$

2-3182 Nordisk Institut for Asienstudier (NIAS) 80

2-3184 Nordisk vulkanologisk institut (NORDVULK) 81

2-3185 Nordisk Samisk Institut (NSI) $\quad 82$

$\begin{array}{lr}\text { Social- og Helsepolitik } & 84\end{array}$

$\begin{array}{ll}\text { Generel indledning } & 84\end{array}$

Projektmedel $\quad 85$

3-4310 Projektmidler - Social- och hälsvårdspolitik 85

3-4311 Nordisk helsesamarbejde - opfølgning af Bo Könbergs rapport 87

3-4320 Rådet för nordiskt samarbete om funktionshinder $\quad 87$

3-4340 Nomesko og Nososko $\quad 88$

3-4382 NIOM A/S - Nordisk Institutt for Odontologiske Materialer 89

$\begin{array}{ll}\text { Institutioner } & 90\end{array}$

3-4380 Nordens Välfärdscenter (NVC) 90

3-4381 Nordic School of Public Health NHV* 92

\section{Kulturpolitik}

Generel indledning $\quad 93$

4-2203 Dispositonsmidler Kultur 96

4-2205 Nordisk Kulturfond 96

4-2206 Nordisk Råds priser $\quad 97$ 
4-2212 Nordisk Børne- og Ungdomskomité (NORDBUK) 100

$\begin{array}{ll}\text { Film og Media } & 101\end{array}$

4-2221 Nordisk computerspilprogram 101

4-2222 Nordisk Film- og TV-fond 102

4-2228 NORDICOM 103

Kunstområdet $\quad 104$

4-2251 Kultur- og Kunstprogrammet 104

4-2253 Nordisk oversættelsesstøtte $\quad 105$

4-2254 Nordiskt-baltiskt mobilitetsprogram för Kultur 107

$\begin{array}{ll}\text { Nordiske Kulturhus } & 108\end{array}$

4-2270 Nordens hus i Reykjavik 108

4-2272 Nordens hus på Färöarna 110

4-2274 Nordens Institut på Åland 111

4-2277 Nordens Institut på Grönland (NAPA) 112

4-2548 Kulturkontakt Nord 114

Andra kultursatsningar $\quad 115$

4-2232 Prioriterade verksamheter $\quad 115$

4-2234 Samiskt samarbete 117

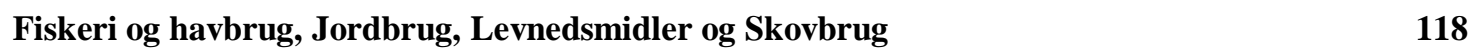

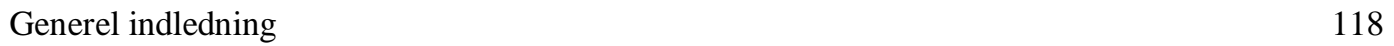

5-6420 Ny nordisk mad $\quad 120$

$\begin{array}{ll}\text { Fiskeri } & 121\end{array}$

5-6610 Projektmidler - Fiskeri 121

$\begin{array}{ll}\text { Jordbrug } & 123\end{array}$

5-6510-1 Projektmidler - Jordbrug 123

5-6520 Kontaktorgan for jordbrugsforskning 124

5-6585 Nordisk Genressource Center (NordGen) 125

$\begin{array}{ll}\text { Levnedsmidler } & 127\end{array}$

5-6810 Projektmidler - levnedsmidler 127

5-6830 Nordisk handlingsplan for bedre helse og livskvalitet $\quad 129$

$\begin{array}{ll}\text { Skovbrug } & 129\end{array}$

5-6310 Projektmidler - Skovbrug 129

5-6581 Samnordisk skogsforskning (SNS) 130

\section{Jämställdhet}

Generel indledning 132

6-4410 Projektmedel - Jämställdhet 134

6-4420 MR-JÄMs stödordning 135

6-4480 Nordisk information för kunskap om kön (NIKK) 136

$\begin{array}{ll}\text { Närings-, Energi- och Regionalpolitik } & 137\end{array}$

$\begin{array}{ll}\text { Generel indledning } & 137\end{array}$

Näring 139

7-5140 Projektmedel - Näring 139

7-5180 Nordisk Innovation $\quad 140$

7-5280 Nopef 142

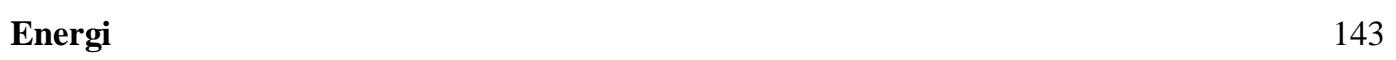

7-5141 Projektmedel - Energi 143

7-3220 Nordisk Energiforskning (NEF) 144

Regional 145 
7-5143 Implementering av samarbetsprogram, demografi, arbetsgrupper och projektmedel 145

7-5151 NORA

7-5160 Gränsregionalt samarbete

7-6180 Nordregio

Miljö

Generel indledning

8-3310 Dispositionsmedel - Miljö

8-3311 Miljøsektorens arbejdsgrupper

8-3312 Nordisk Råds miljøpris

8-3320 NEFCOS Miljøudviklingsfond

157

8-6720 SVANEN - Nordisk Miljömärkning

\section{Arbetslivspolitik}

Generel indledning

161

9-4110 Projektmedel i övrigt - Arbetsliv

163

9-4111 Arbetslivs fasta utskott

164

9-4120 Nordjobb

165

9-4130 Kommunikation om arbetsliv

165

9-4180 Nordiska Institututionen för Vidareutbildning inom Arbetsmiljöområdet (NIVA)

166

Ekonomi- og Finanspolitik

Generel indledning

10-5210 Ekonomi- och Finanspolitik

\section{Lagstiftning}

Generel indledning

11-7110 Projektmedel - Lagstiftning

Budgettets indtægter og landenes indbetalinger

Historisk udvikling i Nordisk Ministerråds budget og likviditet

Besparelse i det nordiske budget 2014 - 2016

Udviklingen i udisponerede midler 2012 - 2014

Nordisk Ministerråds institutioner ikke-forbrugte midler

Budgettets udvikling i perioden 2005 - 2016

Likviditetens udvikling

Bilag 1 - Budgettet konverteret til EURO

Bilag 2 - Status 27.052015 på budgetpostniveau 


\section{Forord}

Det nordiske regjeringssamarbeidet gjennomgår for tiden en omfattende moderniseringsreform. Budsjettforslaget for 2016 er både i form og innhold i stor grad preget av dette. Innretningen og oppbyggingen av budsjettboken er videre utviklet fra 2015 med intensjonen om å presentere et budsjett med tydelige målformuleringer og konkrete resultater. Innholdet i budsjettet viser et dynamisk politisk samarbeid som fanger opp aktuelle og nye prioriteringer. Det har allerede vært god dialog med Nordisk råd om prioriteringer i 2016. Når samarbeidsministrene legger frem sitt budsjettforslag til høsten, vil det bli gjennomført konkrete forhandlinger med Nordisk råd om budsjettet.

Budsjettforslaget bygger på budsjettanvisningene som samarbeidsministrene vedtok tidligere i år. Videre er forslaget basert på innspill fra de 10 fagministerrådene. Budsjettet for 2016 har en samlet reduksjon på 1 \% i forhold til budsjettet for 2015. Denne reduksjonen er fordelt på de to største sektorene, nemlig samarbeidsministrenes eget budsjett samt undervisningssektoren med henholdsvis 70 og $30 \%$ av reduksjonen. Gjennom målrettede prioriteringer har disse to sektorene selv fordelt reduksjonene på sine respektive budsjetter. Alle de øvrige sektorer får videreført sine budsjetter på samme nivå som i 2015.

Gjennom prioriteringsbudsjettet videreføres formannskapsinitiativene fra Islands formannskap i 2014 og Danmarks formannskap i 2015. Det er også satt av 15 MDKK til de initiativer som vil bli iverksatt under det finske formannskapet i 2016. Detaljene knyttet til disse initiativene vil bli presentert i samarbeidsministrenes budsjettforslag til høsten.

Internasjonal profilering og posisjonering av Norden er et politisk satsningsområde etter at samarbeidsministrene vedtok en strategi for dette i 2014. I budsjettforslaget for 2016 er det satt av 10 MDKK som en del av prioriteringsbudsjettet til dette. Sammenhold med også annen finansiering, vil 2016 bli et år med virkelig gode muligheter til å iverksette målrettede tiltak for å profilere og posisjonere Norden i verden.

Det er i prioriteringsbudsjettet også satt av midler til nye politiske initiativer. Hensikten med disse midlene er å medfinansiere gode tverrgående initiativer i sektorene. I budsjettforslaget for 2016 ligger det tre slike initiativer: Klima og bæredyktig utvikling, Nordisk statistikk samt Demokrati, inkludering og sikkerhet. Disse initiativene er gode eksempler på at det nordiske regjeringssamarbeidet responderer på aktuelle utfordringer i Norden og iverksetter initiativer som er politisk dagsaktuelle. Budsjettforslaget inneholder også en ny tverrsektoriell nordisk satsning mot menneskehandel. Flere sektorer er involvert i det nye programmet.

Budsjettforslaget inneholder viktige politiske satsninger i alle sektorer. Gjennomføring og oppfølging av strategiske gjennomlysninger, for eksempel i helsesektoren og arbeidslivssektoren, står sentralt i budsjettet. Det vil også være et kontinuerlig fokus på å bryte ned grensehindre. Likeledes vil det internasjonale samarbeidet fortsatt prioriteres. På grunn av beslutningen om å avvikle virksomheten ved informasjonskontoret i Nordvestrusland, er det satt av midler til relevante og målrettede politiske initiativer i Nordens nærområder.

København 10. juni 2015

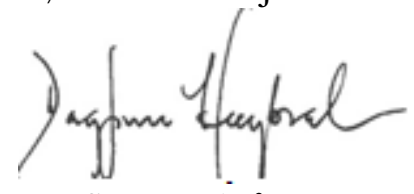

Dagfinn Høybråten

Generalsekretær i Nordisk ministerråd 


\section{Læsevejledning}

Budget 2016 består af tre dele:

Den indledende beskrivelse af Nordisk Ministerråds prioriterede indsatser for 2016 består af de overordnede planer for virksomhedsåret 2016. Hertil kommer tre tabeller, der viser den samlede økonomi i det nordiske samarbejde, herunder 1) den samlede ramme for budgettet fordelt på politiske områder (ministerråd), 2) fordelingen på budgetkategorier (projekter, institutioner mv.) samt 3) hvor 'bundet' budgettet er i aktiviteter, der årligt gentages.

Hoveddelen af budgettet, som er den mest omfattende, indeholder oversigt over samtlige budgetposter, inddelt efter de 11 ministerråd. Hvert ministerråd indledes med en kort beskrivelse af formålet med samarbejdet inden for ministerområdets område, dets strategiske målsætninger for budgetåret samt beskrivelse af de overordnede resultater for senest afsluttede regnskabsår 2014.

Budgettet er baseret på mål og resultatstyring med fastsættelse af mål og resulter på de enkelte budgetposter. Hver enkelt budgetpost indeholder oplysninger om budgetårets budget, de to seneste års budgetter, hvor stor en del af budgettet der blev disponeret sidste år, samt hvem der bemyndiges til at træffe beslutning om anvendelsen af bevillingen. Herudover er der til hver budgetpost en beskrivelse af formålet med bevillingen.

Som noget nyt indgår der i budget 2016 for institutionerne en note vedrørende budgetposter som institutionerne eventuelt forvalter i tillæg til egen bevilling. Hertil kommer oplysninger om eventuelle særlige dispositionsbestemmelser for institutionernes bestyrelser vedrørende dele af institutionernes budget. Dette følger af ny styringsmodel for institutionerne, som træder i kraft per 1. januar 2016.

Budgetposterne er inddelt i 4 forskellige kategorier: projektmidler, programlignende aktiviteter, institutioner og organisationsbidrag. Se fordelingen og uddybende forklaring i nedenstående afsnit, der viser budgettet i hovedtal.

Sidste del af budgettet består af tværgående oversigter, herunder oplysninger om finansieringen fordelt på lande og betalingsordningen for højere uddannelse. Hertil kommer historiske data om udviklingen i det samlede budget, likviditeten, og de udisponerede midler samt nogle bilag med bl.a. budgettet i euro, økonomiske delegeringsregler og en fortegnelse over brugte forkortelser. Hertil kommeren oversigt over institutionernes egenkapital.

\section{Uddybning af budgetstruktur og budgetpost- kategorier}

\section{Hovedinddeling}

Budgettets hovedinddeling er det enkelte ministerråd. Præsentationen af hvert ministerråd indledes med en beskrivelse af hele arbejdet med fokus på politiske målsætninger, nye initiativer og ændringer i forhold til foregående budgetår samt de opnåede resultater fra senest afsluttede budgetår.

\section{Budgetposter}

De enkelte budgetposter præsenteres ensartet indholdsmæssigt ved hjælp af fire budgetposttyper; 1) Projektmidler, 2) Programlignende aktiviteter som rummer samarbejdsorganer, rene programmer, støtteordninger/samarbejdsorgan og arbejdsgrupper 3) Institutioner/virksomheder som styres gennem mål - og resultatkontrakter samt 4) organisationsbidrag. Under hver 
budgetpost er der fokus på mål for budgetåret, mål for året hvori budgettet udarbejdes (det vil sige 2015 for nærværende budget) samt de væsentligste resultater for senest afsluttede budgetår (det vil sige 2014 for nærværende budget),

Hver budgetpost har en 5 cifret nummerering. Det første ciffer er samarbejdsområde, hvilket modsvarer rækkefølge og inddeling i nedenstående afsnit, der viser budgettet i hovedtal. Anden til femte ciffer er løbenummer indenfor ministerrådet, og dermed budgetpostens unikke numeriske id. Endelig er der for hver budgetpost i parentes angivet, hvilken budgetkategori budgetposten hører under.

\section{Specielle rubrikker}

I budgetpostene for projektmidler viser rubrikken Disp./Bud.14, hvor stor andel af 14-budgettet i procent, som er disponeret i løbet af 2014. En disponering er en beslutning om at bruge penge fra en budgetpost til et bestemt formål. Det disponerede beløb kan udbetales til formålet i budgetåret og i de 2 på følgende år, og Nordisk Ministerråd har en forpligtelse overfor det angivne formål i denne tidsperiode. En ikke udbetalt disposition vil efter 3 år blive indtægtsført i ministerrådets regnskab og tilbagebetalt til landene.

For så vidt angår videreførselsreglen for udisponerede midler på budgetpostniveau, er det muligt at videreføre 15 \% af årets bevilling på en budgetpost, dog med en minimumsgrænse på 150 TDKK.

I budgetposterne for institutioner styret med resultatkontrakt viser rubrikken, NMR fin. 14 den procentvise andel af institutionens totale indtægter i 2014 som blev finansieret af Nordisk Ministerråd (fra regnskabet). Finansieringen fra Nordisk Ministerråd omfatter både basisbevilling og eventuelle projektmidler.

I rubrikken "kontraktstatus” redegøres for institutions målopfyldelse f.s.v.a. de faglige mål i resultatkontrakterne. 


\section{Den totale udgiftsramme for Nordisk Ministerråds budget for virksomhedsåret 2016}

Den totale udgiftsramme for 2016 for Nordisk Ministerråd er i alt 922.464 TDKK i 2015 priser, som er 1 \% nedskæring i rammen i forhold til 2015.

SAMMENSTILLING AF BUDGET 2016 OG 2015 (2015 priser)

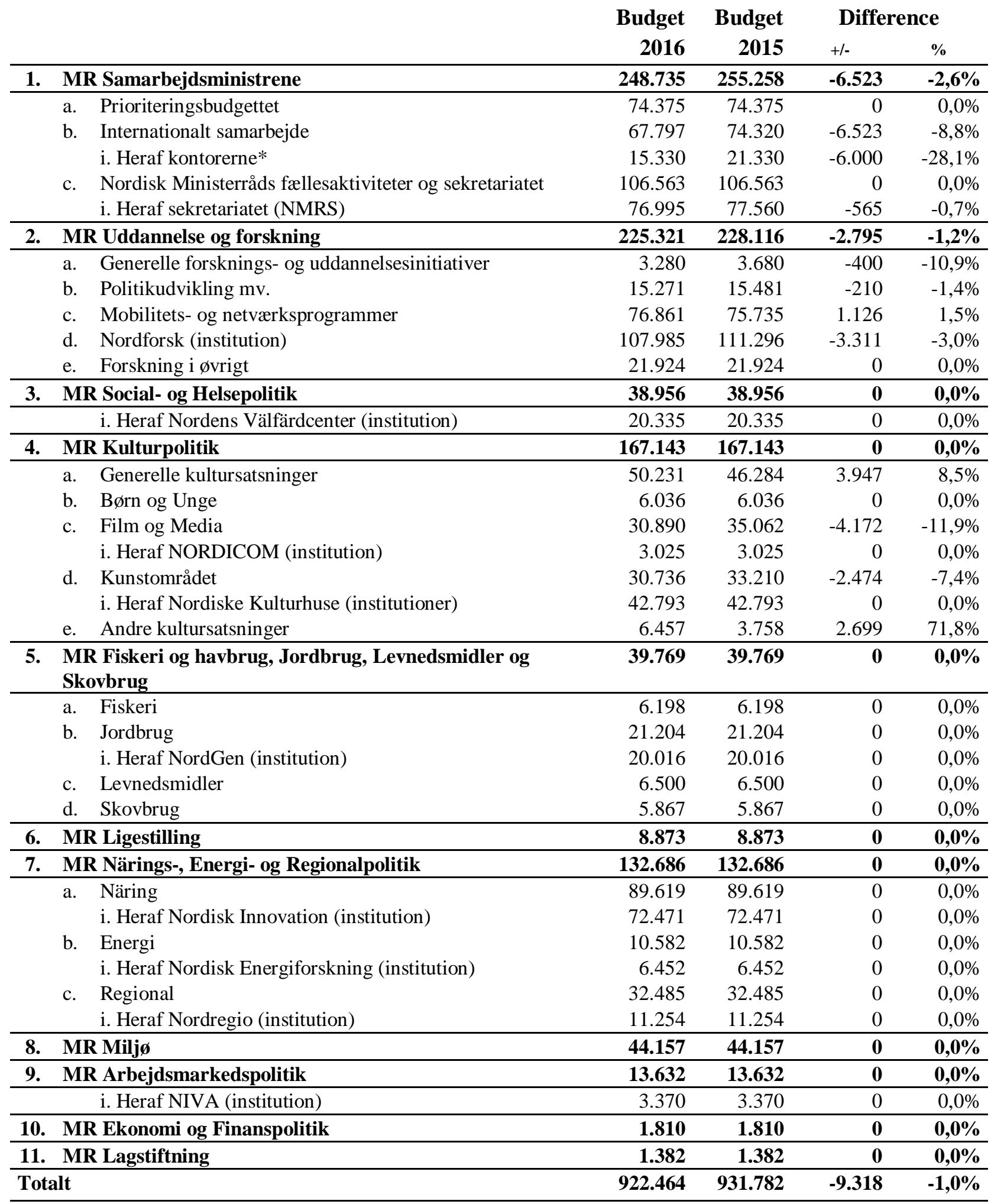

*Ministerrådets kontorer i Estland, Letland, Litauen og Nordvestrusland 


\section{Budgettets fordeling på budgetpostkategorier}

Nedenfor vises budgettet fordelt på budgetkategorier. Foruden de fire kategorier, projektmidler, programlignende aktiviteter, institutioner og organisationsbidrag, er prioriteringsbudgettet skilt ud som selvstændig kategori. Derudover er bevillingerne til ministerrådssekretariatet og kontorerne i Estland, Letland, Litauen og i Nordvestrusland, defineret som institutioner, men vist separat i diagrammerne nedenfor.

De ordninger, som administreres af de nordiske institutioner NordForsk og Nordisk Innovation indgår i institutionsandelen. Nedenstående tabel viser udvikling i budgettets fordeling på udgiftskategorier.

\section{TDKK}

Budget 2016

Budget 2015

\begin{tabular}{lrrrr}
\hline Prioriteringsbudget & 74.375 & $8,1 \%$ & 74.375 & $8,0 \%$ \\
Institutioner & 287.701 & $31,2 \%$ & 293.550 & $31,5 \%$ \\
Programlignende aktiviteter & 341.248 & $37,0 \%$ & 342.547 & $36,8 \%$ \\
Projektmidler & 105.583 & $11,4 \%$ & 103.887 & $11,1 \%$ \\
Organisationsbidrag & 21.232 & $2,3 \%$ & 18.533 & $2,0 \%$ \\
Sekretariatet og kontorerne & 92.325 & $10,0 \%$ & 98.890 & $10,6 \%$ \\
\hline I alt & 922.464 & $100 \%$ & 931.782 & $100 \%$
\end{tabular}

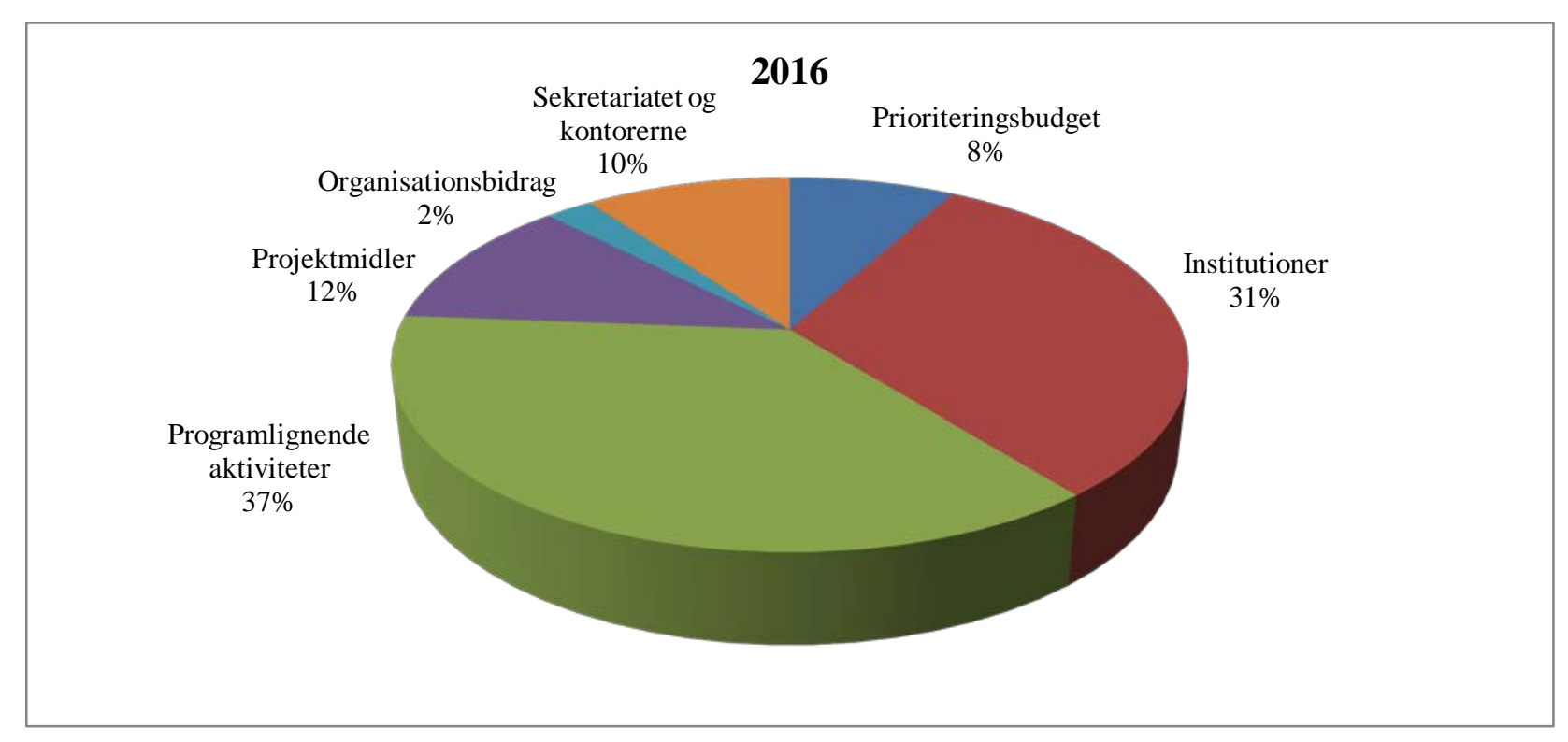




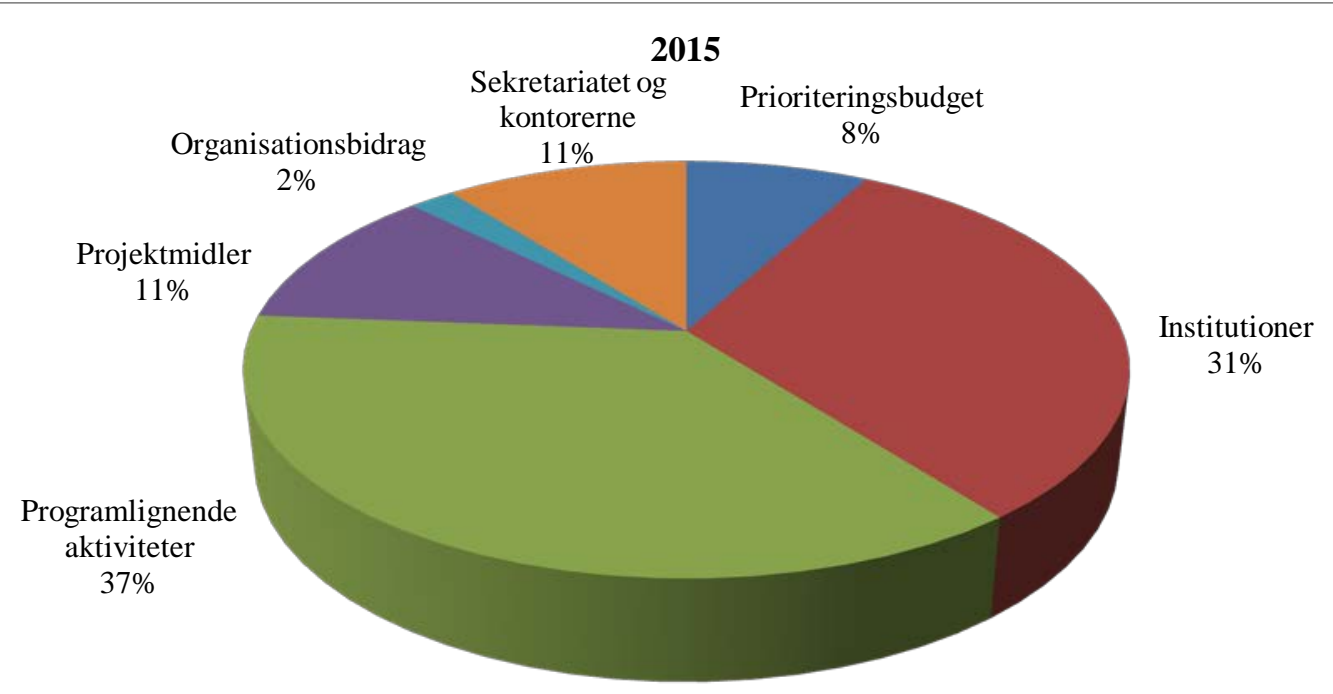

\section{Økonomiske og politiske frihedsgrader i Nordisk Ministerråds budget}

Det nordiske budget er ikke bundet ud over det enkelte budgetår, hvorfor nedenstående tabel alene tjener det formål at vise, hvor stor en andel af budgettet der årligt træffes beslutning om før budgettets vedtagelse, og hvor stor en andel af budgettet, der træffes beslutning om efter budgettets vedtagelse; dvs. hvor mange midler, der udmøntes i løbet af det givne budgetår. I forhold til sidstnævnte vises således, hvilke mål og aktiviteter, der årligt træffes beslutning om at videreføre i regi af det nordiske samarbejde.

\begin{tabular}{|c|c|c|c|c|c|c|c|c|c|c|c|c|}
\hline \multirow{2}{*}{$\begin{array}{l}\text { Budget } 2016 \text { i } 2015 \text { priser } \\
\text { Nordisk budget total }\end{array}$} & \multirow[b]{2}{*}{922.464} & \multicolumn{11}{|c|}{ Fordelt på sektorer } \\
\hline & & MR-U & MR-S & MR-K & MR-FJLS & MR-LIG & MR-NER & R-MILJØ & AR-A & MR-FIN & MR-LOV & MR-SAM \\
\hline $\begin{array}{l}\text { Træffes beslutning om } \\
\text { inden for budgetåret }\end{array}$ & 103.971 & & & & & & & & & & & \\
\hline Projektmidler & 61.916 & 3.280 & 5.811 & 12.049 & 975 & 3.493 & 6.686 & 4.241 & 907 & 1.810 & 1.382 & 21.282 \\
\hline Programlignende aktiviteter & 42.055 & 7.480 & 3.015 & & 11.491 & 2.842 & 4.750 & & & & & 12.477 \\
\hline Faste aktiviteter & 818.493 & & & & & & & & & & & \\
\hline Prioriteringspulje & 74.375 & & & & & & & & & & & \\
\hline Projekter, programmer mv. & 342.860 & 106.576 & 9.795 & 102.819 & 7.287 & 2.538 & 24.449 & 35.717 & 9.355 & & & 44.324 \\
\hline Institutioner & 380.026 & 107.985 & 20.335 & 45.818 & 20.016 & & 90.177 & 0 & 3.370 & & & 92.325 \\
\hline Organisastionsbidrag & 21.232 & 6.457 & & & & & 6.624 & 4.199 & & & & 3.952 \\
\hline
\end{tabular}

\section{Udmøntes inden for budgetåret:}

Midler der benyttes til korte, enkeltstående og tidsbegrænsede projekter. Det er midler, der tildeles på ad hoc basis, og i løbet af budgetåret. Under denne overskrift ligger udover projektmidlerne også de midler, der i de nordiske institutioner har projektlignende karakter. Der er tale om midler, hvor der ikke truftet nærmere beslutning om mål og aktiviteter i forbindse med budgettets vedtagelse.

\section{Faste aktiviteter:}

Denne del af tabellen af viser midler til aktiviteter, der historisk er støttet over flere år i det nordiske budget. Det drejer sig om:

Prioriteringspuljen: Samarbejdsministrene har truffet beslutning om oprettelsen af en pulje, der kan udmøntes til nye, større tværgående prioriterede satsninger. 
Kontraktbundne midler (projekter, programmer mv.): Midler hvor Nordisk Ministerråd har givet signal om, eller hvor der i forbindelse med uddeling af midler klart fra Nordisk Ministerråd ligger en hensigtserklæring om finansiering over flere år. I denne kategori medtages midler, hvor Nordisk Ministerråd er den eneste finansieringskilde. Det drejer sig om fx støtteordninger og større programmer og eventuelt samarbejdsorganer og arbejdsgrupper.

Nordiske institutioner: Denne kategori er kun aktuel for de nordiske institutioner og sekretariater. Det drejer sig om bevilling til disse enheder, som modtager en fast årlig bevilling. 


\section{Nordisk Ministerråds planer for virksomhedsåret 2016}

\section{Hovedlinjerne i budget 2016}

Nordisk Minsiterråd er et forum for det formelle samarbejde mellem de nordiske regeringer. Ministerrådets arbejde er reguleret af Helsingforsaftalen, der senest blev ændret i 1995.

Det er de nordiske smarbejdsminsitre (MR-SAM), der har det overordnede ansvar for at koordinere ministerrådets arbejde. Herudover udføres samarbejdet i 10 fagministerråd.

Formandskabet for Nordisk Ministerråd skifter årligt og roterer mellem landene. Finland afløser i 2016 Danmark som formandskabsland for Nordisk Ministerråd.

De nordiske samarbejdsministre har besluttet, at det nordiske budget i 2016 skal reduceres med $1 \%$. Af denne besparelse tages henholdsvis $70 \%$ fra samarbejdsministrenes eget budget, mens de resterende $30 \%$ tages fra uddannelsesministrenes (MR-U) budget.

I 2015 blev de prioriterede satsninger Grøn Vækst og Bæredygtig Nordisk Velfærd afsluttet, hvilket har skabt plads for nye tværgående strategiske satsninger under de nordiske samarbejdsministres proriteringsbudget i 2016. Se i øvrigt afsnit om hovedlinjerne for for de politiske prioriteringer nedenfor.

I indeværende år fortsættes formandskabsprojekterne fra Island (2014) og Danmark (2015) mens Finland som siddende formandskab lancerer sine prioriterede formandskabsprojekter.

Budgettet er udarbejdet på baggrund af fagministerrådenes indspil til prioriteringer, og fremsættes som generalsekretærens budgetforslag i juni 2015, som herefter sendes i national høring i de nordiske lande, hvorefter samarbejdsministrene i september når til enighed om budgetforslaget. Det endelige budget for Nordisk Ministerråd i 2016 vedtages af de nordiske samarbejdsministre i oktober 2015 efter drøftelser med Nordisk Råd.

\section{Hovedlinjer i Nordisk Ministerråds politiske prioriteringer 2016}

I 2013 fik generalsekretæren mandat til at se på mulighederne for at effektivisere og forbedre det nordiske regeringssamarbejde i Nordisk Ministerråd. I overensstemmelse med mandatet blev der i løbet af efteråret 2013 og foråret 2014 udarbejdet modernisaeringsrapporten ”Nyt Norden”. På baggrund af rapporten traf samarbejdsministrene juni 2014 beslutning om en amitiøs reformpakke, som implementeres i perioden 2014-16. Målene med reformen er at opnå 1) et stcrkt nordisk samarbejde på ministerniveau, herunder et nyt nordisk budget, 2) et effektivt sekretariat, 3) mere nordisk nytte fra projekt- og programvirksomheden samt 4) en bedre styring af de nordiske institutioner.

Et af de værktøjer der styrker det nordiske regeringssamarbejde er de nordiske samarbejdsministres prioriteringsbudget som har eksisteret siden 2013. Formålet med prioriteringsbudgettet er at muliggøre og facilitere igangsættelsen af nye og større og tværsektorielle satsninger samt de enkeltes landes formandskabsprojekter.

I 2016 vil den øvrige del af prioriteringsbudgettet blandt andet blive brugt til at følge op på Nordisk Ministerråds nye strategi for profilering og positionering fra 2015 for at sikre at de nordiske landes konkurrenceevne og internationale indflydelse styrkes gennem samordnede profilerende aktiviteter i et fælles initiativ.

Dertil kommer tre nye tvægående satsninger der omfatter et nordisk statistiksamarbejde, miljø og klima samt en ny fælles nordisk satsning der skal styrke demokrati, inkludering og sikkerhed gennem bekæmpelse af social marginaliseing, ekstremisme og religiøs diskriminering. 
I 2016 vil der desuden være fokus opfølgning af de strategiske gennemlysninger af henholdsvis sundhedssektoren (Könberg-rapporten) og arbejdslivssektoren. Der vil desuden igangsættes endnu en strategisk gennemlysning af en sektor inden for Nordisk Ministerråd.

Nordisk Ministerråd prioriterer også det arbedje som støtter mennesker og virksomheders grænseoverskridende aktiviteter i Norden. Grænsehindringsarbejdet ligger således fortsat højt på den politiske dagsorden i Nordisk Ministerråd. Der sker blandt anden en koordinering og samarbejde mellem landene i nationale lovgivningsprocesser samt implemtering af EU-lovgivning.

Nordisk Ministerråds internationale samarbejde fokuserer i 2016 på at udvikle samarbejdsrelationerne man har med Nordens nabolande og andre aktører. 


\section{Samarbetsministrarna}

\section{Generel Indledning}

Formål og Samarbejdsministrene er ansvarlige for det nordiske regeringssamarbejde på vegne af de Fakta nordiske statsministre og har en koordinerende rolle i mange af de tværgående aktiviteter i det nordiske samarbejde. Det gælder eksempelvis det nordiske prioriteringsbudget, det internationale samarbejde og de fælles nordiske aktiviteter.

Nordisk Ministerråds internationale samarbejde har til formål at sikre stabilitet og samarbejde med Nordens nærområder samt nordisk nytte i verden. Samarbejdet omfatter Estland, Letland og Litauen og Nordvestrusland i øst, Tyskland og Polen i syd og blandt andet Canada i vest samt det arktiske samarbejde. Desuden har Nordisk Ministerråd en politik for aktiviteter i Hviderusland, hvor man primært fokuserer på demokratiudvikling, støtte til civilsamfundet og uddannelse af unge hviderussere.

Nordisk Ministerråd har også et nært samarbejde med de øvrige regionale aktører og organisationer i Nordeuropa, heriblandt Østersørådet, Barentsrådet og Arktisk Råd. I de seneste år er samarbejdet med EU desuden blevet udviklet på en række områder. Nordisk Ministerråds internationale samarbejde omfatter også nordisk samarbejde i en global kontekst.

Øvrige fælles nordiske aktiviteter under samarbejdsministrene omfatter eksempelvis Bæredygtig Udvikling og Grænsehindringsrådet. Dertil kommer poster af teknisk og administrativ karakter som bidrag til Vestnorden, udveksling af tjenestemænd og generalsekretærens disponeringsreserve. Resterende budgetposter har primært et kommunikations- og formidlingsperspektiv.

Strategiske målsætninger 2016
De strategiske målsætninger for 2016 tager udgangspunkt i samarbejdsministrenes vision for det nordiske samarbejde. Visionens søjler er: Et grænseløst Norden, et innovativt Norden, et synligt Norden og et udadvendt Norden.

Samarbejdsministrene vil i 2016 fortsat arbejde for at det nordiske samarbejde forbliver et dynamisk redskab til at håndtere fælles nordiske politiske udfordringer. Dette skal blandt andet gøres gennem den endelige implementering af anbefalingerne fra moderniseringsrapporten Nyt Norden.

Til dette arbejde har samarbejdsministrene blandt andet prioriteringsbudgettet til rådighed der skal anvendes til at igangsætte nye, større og prioriterede satsninger. Prioriteringsbudgettet er opdelt i en formandskabsdel og en øvrig del.

Indenfor rammen af prioriteringsbudgettet 2016 vil samarbejdsministrene fokusere på de strategiske satsninger under det finske formandskab, arbejdet med profilering og positionering af Norden, politiske initiativer i Nordens nærområder samt nye tværgående initiativer. Dertil kommer nye strategiske gennemlysninger af relevante sektorer samt opfølgning på eksisterende gennemlysninger.

Prioriteringsbudgettet 2016 er på i alt 74,375 MDKK. Af disse udgør formandskabsdelen45 MDKK og er dermed øremærket til formandskabsinitiativerne. Midlerne øremærkes til et formandskab fra og med formandskabsåret og tre år frem. I 2016 afsættes 15 MDKK til Island (formandskab 2014), 15 MDKK til Danmark (formandskab 2015) og 15 MDKK til Finland (formandskab 2016). Den øvrige del af prioriteringsbudgettet (29,375 MDKK), som kendetegner de største ændringer af prioriteringsbudgettet 2016, anvendes i 2016 til at finansiere nye tværgående initiativer, 
strategiske gennemlysninger, arbejdet med profilering og positionering af Norden samt politiske initiativer i Nordens nærområder. Muligheden for at finansiere disse satsninger er blevet muliggjort med afslutningen af ministerrådets større programmer Grøn Vækst og Bæredygtig Nordisk Velfærd i 2015.

Indenfor rammen for det internationale samarbejde vil fokus i 2016 være på udvikling af samarbejdsmuligheder med Nordens nabolande og andre aktører samt udvikling af eksisterende finansieringsinstrumenter.

Samarbejdsministrene besluttede i 2015 at gennemføre en besparelse på $1 \%$ på det nordiske budget i 2016 på i alt 9,318 MDKK. 70 \% af denne besparelse skal afholdes på samarbejdsministrenes budget svarende til 6,523 MDKK. For samarbejdsministrenes vedkommende vil denne besparelse, i lyset af ændringerne i Ruslandssamarbejdet, blive udmøntet på budgetposterne 1-0820 Kunskapsuppbyggning och netvärk (0,523 MDKK) samt 1-0970 Ministerrådets kontor i nordvästra Ryssland (6 MDKK).

Ministerrådets resultater i 2014
I 2014 har formandskabsdelen under prioriteringsbudgettet bidraget til at igangsætte de islandske formandskabsprojekter Bioøkonomi, Velfærdsvagten og Nordic Playlist. Dertil kommer videreførelsen af formandskabsprojekterne fra 2013 under det svenske formandskab i form af Nordmin, Forbedrede emissionsopgørelser af kortvarige klimapåvirkende luftforureninger og Læring på arbejdspladsen.

Prioriteringsbudgettet har fortsat finansieret statsministerintiativerne Grøn Vækst og Bæredygtig Nordisk Velfærd samt afsluttet flere globaliseringsprojekter som eksempelvis Nordic Built, der er blevet brugt som grundlag for et dansk formandskabsprojekt i 2015.

Samarbejdsministrene traf i 2014 beslutning om deres vision for det nordiske samarbejde, der fremover skal bygges på de fire følgende søjler: Et grænseløst Norden, et innovativt Norden, et synligt Norden og et udadvendt Norden.

Arbejdet med modernisering af Nordisk Ministerråd resulterede i 2014 i rapporten Nyt Norden der indeholdt 39 anbefalinger til et mere effektivt og politisk nordisk samarbejde. Samarbejdsministrene vedtog på den baggrund en ambitiøs reformpakke, som skal sikre, at Nordisk Ministerråd forbliver et stærkt og relevant redskab for de nordiske regeringer i mødet med nye politiske udfordringer.

Samarbejdsministrene vedtog i 2014 en strategi for profilering og positionering af Norden for at sikre at de nordiske landes konkurrenceevne og internationale indflydelse styrkes gennem samordnede profilerende aktiviteter i et fælles initiativ.

Samarbejdsministrene har i 2014 bidraget til finansiering af rapporten, Det fremtidige nordiske sundhedssamarbejde, under ledelse af tidligere svensk sundhedsminister Bo Könberg. Rapporten opstillede 14 konkrete forslag til forbedring af det nordiske sundhedssamarbejde, som ministerrådet arbejder med en opfølgning af. 


\section{Moderniseringsreformen:}

Samarbejdsministrene vedtog 26. juni 2014 en samlet reformpakke, der danner grundlag for en omfattende fornyelse af det nordiske regeringssamarbejde, og som vil sætte et varigt præg på samarbejdet. Reformpakken er under implementering i 2014-2016.

\section{Fire mål med moderniseringsreformen:}

- Forstærket samarbejde på ministerniveau samt et bedre budget

- Mere tydelig ejerstyring af de nordiske institutioner

- Mere målrettet brug af nordiske projekter

- Et effektivt sekretariat som initierer og følger op på politiske beslutninger

Forstcerket politisk samarbejde

Reformens fokus er på at styrke det politiske samarbejde i Nordisk Ministerråd, herunder ved større fokus på strategi og udvikling af fællesnordisk politik og fællesnordiske løsninger, sikre et budget med integreret mål og resultatstyring som forudsætning for prioritering og styring af det nordiske samarbejde, herunder også et styrket samarbejde med Nordisk Råd i budgetprocessen. Hertil kommer endvidere fokus på internationale spørgsmål samt styrket tværsektorielt samarbejde på politisk niveau.

\section{Institutionsreform:}

Ny styringsmodel, hvor bestyrelsen fortsætter et fagligt ansvar, men hvor det formelle juridiske og økonomiske ansvar for institutionen placeres hos direktøren som rapporterer til generalsekretæren. Der indføres et årligt bevillingsbrev, som præciserer de i budgettet og resultatkontrakten fastsatte mål. Direktøren rekrutteres af generalsekretæren i dialog med bestyrelsen.

Nordiske projekter:

Klart mål for projekter og programmer og god opfølgning på resultater, hvor viden og resultater skal formidles og udnyttes bedre med løbende og systematisk feedback til relevante politiske udvalg. Til grund herfor ligger blandt andet en mere effektiv administration samt fokus på mere sammenhængende projektaktiviteter.

Et effektivt sekretariat:

Et effektivt sekretariat, der støtter op under det politiske samarbejde ved at stille forslag til fælles nordiske løsninger og gennemføre det politisk vedtagne, er en forudsætning for et effektivt nordisk samarbejde.

Sekretariatet skal være en drivkraft i udvikling af det nordiske samarbejde 


\section{Prioriteringsbudget}

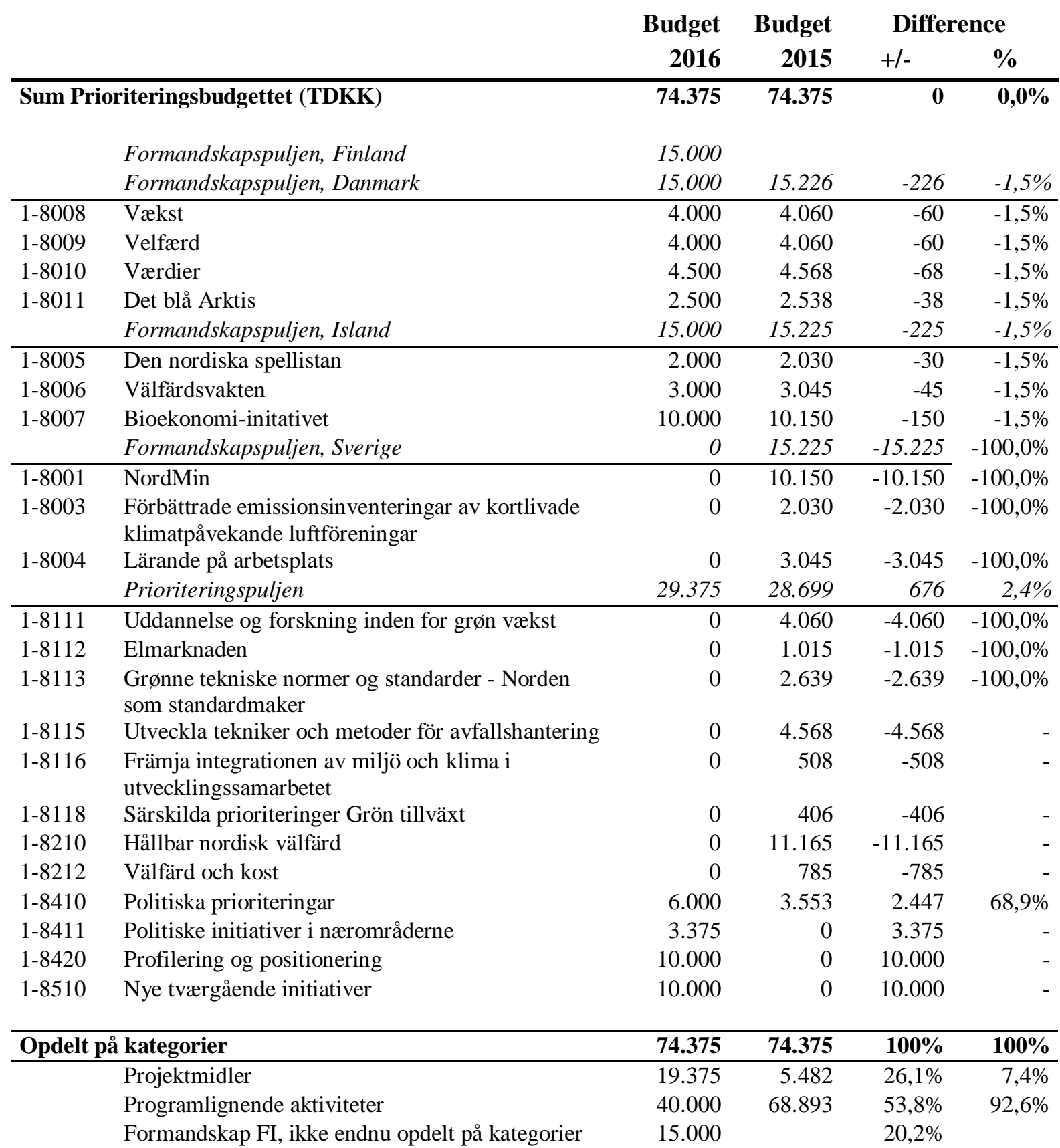

\section{Formandskabsdelen}

1. Projekter under formandskabsdelen af prioriteringsbudgettet initieres af formandskabet og godkendes af MR-SAM. Formålet med prioriteringsbudgettet er at muliggøre igangsættelse af nye og større tematiserede satsninger med fokus på aktuelle politiske prioriteter inden for Nordisk Ministerråd. I 2015 godkendte MR-SAM nye retningslinjer anvendelse af formandskabsdelen af prioriteringsbudgettet, hvilket indebærer at projekterne herunder som udgangspunkt:

- $\quad$ er større strategiske og innovative satsninger (som hovedregel projekter på minimum 5 mio. DKK årligt), som skaber nordisk merværdi

- har deltagelse fra minimum tre nordiske lande

- maksimalt gives støtte i tre år 
- $\quad$ er tænkt ind i den ramme, som eksisterende nordisk samarbejde udgør, herunder også tidligere og pågående formandskabsprojekter, således at man undgår duplikation men samtidig tilstræber sammenhæng.

Danmarks formandskabspulje

$\underline{1-8008 \text { Vækst }}$

\section{Programlignende aktiviteter}

\begin{tabular}{|l|c|c|c|c|c|} 
Valuta & Budget 2016 & Budget 2015 & Budget 2014 & Disp./bud. 14 & Budget disp. af \\
\hline DKK & 4.000 .000 & 4.060 .000 & 0 & $0 \%$ & NSK/MR-SAM
\end{tabular}

Formål Programmet skal bidrage til at videreudvikle de positioner hvor Nordens

styrkepositioner inden for bæredygtig vækst og beskæftigelse, allerede er synlige. Gennem inddragelse af flere ministerråd og arbejdes der med tre delprojekter, der fokuserer på henholdsvis udvikling af bæredygtige og attraktive byer (MR-NER), udvikling af en ressourceeffektiv nordisk mode- og tekstilproduktion (MR-M) samt en bedre og mere miljørigtig udnyttelse af havets biologiske ressourcer (MR-FJLS).

Forvaltnings- Erhvervsstyrelsen

organ Ministeriet for By, Bolig og Landdistrikter

Miljøministeriet/styrelsen

Fiskeriministeriet, Færøerne

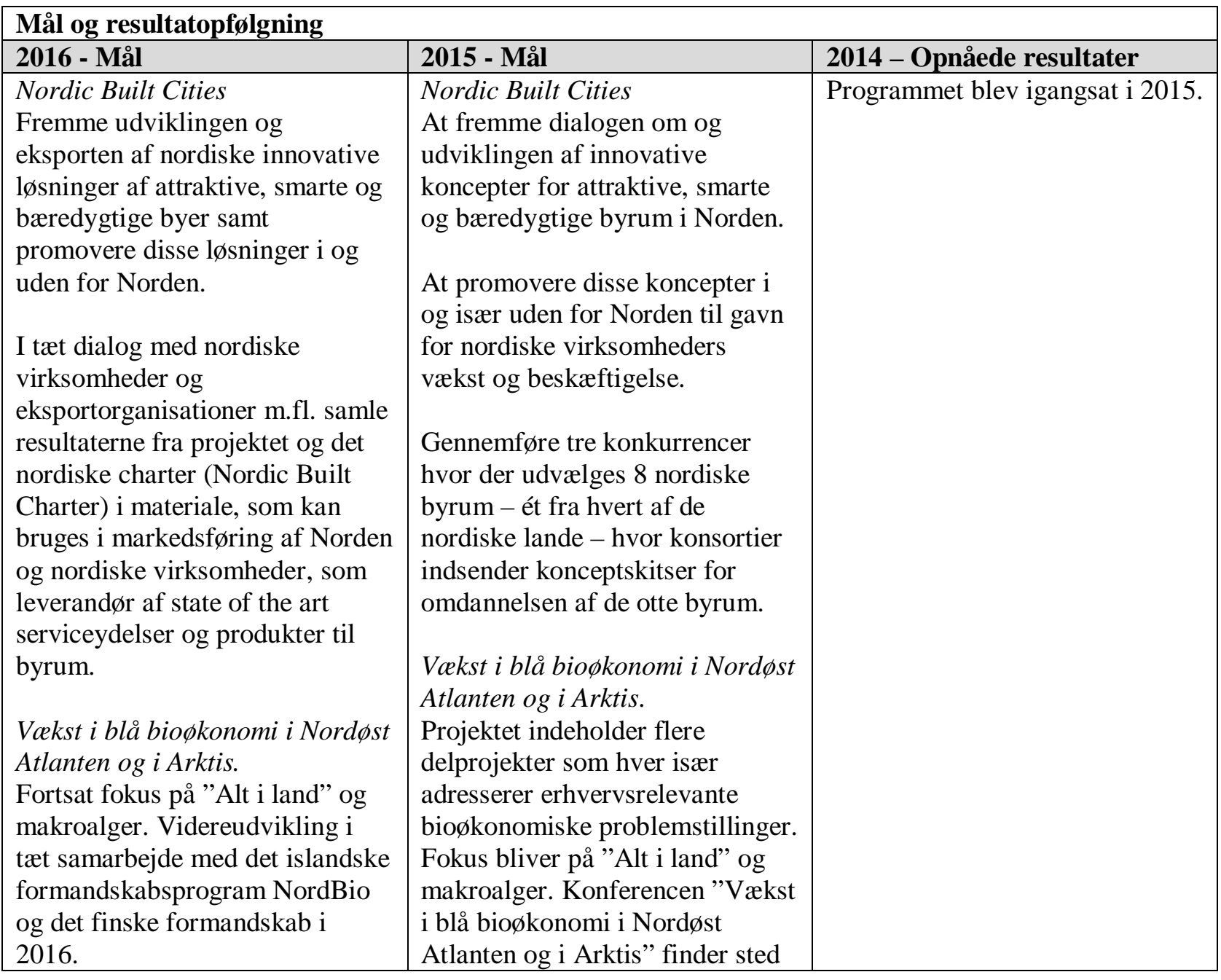


Udvikling af en ressourceeffektiv nordisk mode- og

tekstilproduktion

At implementere første del af tekstilhandlingsplanen og få iværksat de konkrete initiativer i planen. Derudover skal der i 2016 søges yderligere understøttelse af planen og evt. forankring i andre relevante sektorer.
på Færøerne i primo juni.
Konference om recirkulationsanlæg i
akvakulturen afholdes. Endvidere arrangeres aktiviteter i Danmark, Færøerne og Grønland, hvor tang præsenteres som mad.
Udvikling af en ressourceeffektiv nordisk mode- og tekstilproduktion
At opstille konkrete initiativer og handlingsplan for en mere ressourceeffektiv og bæredygtig nordisk mode- og tekstilproduktion, der kan sikre at de nordiske lande fremover arbejder målrettet inden for dette område til gavn for miljøet, beskæftigelse og eksport.

1-8009 Velfærd

Programlignende aktiviteter

\begin{tabular}{|l|c|c|c|c|c|} 
Valuta & Budget 2016 & Budget 2015 & Budget 2014 & Disp./bud. 14 & Budget disp. af \\
\hline DKK & 4.000 .000 & 4.060 .000 & 0 & $0 \%$ & NSK/MR-SAM
\end{tabular}

Formål Programmet fokuserer på to udvalgte velfærdsområder for at udvikle den nordiske velfærdsstat: Digitale løsninger, der kan gøre en konkret forskel på en række borgernære områder (MR-NER) og et struktureret vidensamarbejde inden for god pædagogisk praksis og god undervisning til brug for praktikere med henblik på at understøtte bedre faglige resultater, at betydningen af negativ social arv mindskes og at børn og unge oplever en øget trivsel (MR-U).

Nordens fælles ressourcer og viden på disse områder skal udnyttes for at sikre velfærden på længere sigt.

Forvaltnings- Undervisningsministeriet organ Erhvervsstyrelsen

\begin{tabular}{|c|c|c|}
\hline \multicolumn{3}{|l|}{ Mål og resultatopfølgning } \\
\hline 2016 - Mål & 2015 - Mål & 2014 - Opnåede resultater \\
\hline $\begin{array}{l}\text { Det digitale Norden } \\
\text { Iværksætte initiativer, der kan } \\
\text { ruste Norden digitalt til } \\
\text { fremtidens udfordringer. } \\
\text { Viden, der gør børn dygtige og } \\
\text { livsduelige } \\
\text { Forummet som blev etableret i } \\
2015 \text { skal ved udgangen af } 2017 \\
\text { have udviklet vidensamarbejdet } \\
\text { mellem de nordiske lande, }\end{array}$ & $\begin{array}{l}\text { Det digitale Norden } \\
\text { Iværksætte initiativer, der kan } \\
\text { ruste Norden digitalt til } \\
\text { fremtidens udfordringer for } \\
\text { velfærden. } \\
\text { Viden, der gør børn dygtige og } \\
\text { livsduelige } \\
\text { Etablering af et tværnordisk } \\
\text { forum, der skal styrke det } \\
\text { nordiske samarbejde om at }\end{array}$ & Programmet blev igangsat i 2015. \\
\hline
\end{tabular}


defineret en fremtidig model for samarbejdet og bidraget til at øge praktikeres adgang til og brug af viden. Der vil endvidere være foretaget konkrete kortlægninger af, og udviklet viden om og forslag til, hvordan der i de nordiske lande arbejdes med praktikeres adgang til og brug af viden, der gør børn og unge dygtige og livsduelige med udgangspunkt i de relevante udfordringer (lave faglige resultater, mindskning af negativ social arv) på dagtilbuds- og grundskoleområdet. udvikle og anvende viden, så god undervisning og god pædagogisk praksis i endnu højere grad gør børn og unge så dygtige de kan, og at børn og unge oplever en øget trivsel.

\section{1-8010 Værdier}

Programlignende aktiviteter

\begin{tabular}{|l|c|c|c|c|c|} 
Valuta & Budget 2016 & Budget 2015 & Budget 2014 & Disp./bud. 14 & Budget disp. af \\
\hline DKK & 4.500 .000 & 4.568 .000 & 0 & $0 \%$ & NSK/MR-SAM
\end{tabular}

Formål Programmet skal bidrage til at udnytte og udbygge den positive internationale omtale Norden har fået de seneste år. Programmet vil fokusere på ny nordisk mad (MR-FJLS) og øget turisme (MR-NER), men skal også igangsætte en langsigtet indsats for en fælles international branding af Norden med fokus på fælles nordiske kulturfremstød som Nordic Cool (MR-K). Arbejdet skal ske i overensstemmelse med Nordisk Ministerråds nye strategi for profilering og positionering 2015-2018.

Forvaltnings- Nordisk Innovation/Visit Denmark organ

Kulturministeriet/styrelsen

FOOD Fødevareministeriet

Nordic Economic Policy Review (NMR)

\begin{tabular}{|l|l|l|}
\hline Mål og resultatopfølgning & 2015 - Mål & 2014 - Opnåede resultater \\
\hline 2016 - Mål & Ny nordisk turisme & Programmet blev igangsat i 2015. \\
Øge kendskabet til Norden & Øge kendskabet til Norden \\
gennem færdiggørelse af den nye & $\begin{array}{l}\text { gennem færdiggørelse af den nye } \\
\text { strategi for international }\end{array}$ & \\
profilering og positionering. Ny & $\begin{array}{l}\text { nordiske brandingstrategi. Ny } \\
\text { nordisk turisme vil med }\end{array}$ & \\
Nordisk Turisme vil med & udgangspunkt i turismesektoren i & \\
udgangspunkt i turismesektoren i & Kina, afprøve potentialet og \\
Kina, afprøve potentialet og & behovet for nordiske netværk, der \\
behovet for nordiske netværk, der & $\begin{array}{l}\text { kan profilere Norden } \\
\text { kan profilere Norden }\end{array}$ & \\
internationalt og øge antallet af & internationalt. \\
turismeovernatninger fra Kina til & Konceptudvikling af Nordic Cool & \\
alle Nordiske lande med 7,5 \% & Profilere nordiske kerneværdier \\
per år. & som ligestilling, demokrati, og & \\
Konceptudvikling af Nordic Cool & inddragelse internationalt \\
gennem udvikling af koncept for & \\
\hline
\end{tabular}




\begin{tabular}{|l|l|l|}
\hline $\begin{array}{l}\text { Implementering av koncept för } \\
\text { nordiska kultursatsninger i } \\
\text { uandet på en konkret destination ska genomföras en } \\
\text { festival 2017. }\end{array}$ & $\begin{array}{l}\text { fælles kultursatsninger som } \\
\text { baseres på erfaringerne fra } \\
\text { kulturfestivalen Nordic Cool i } \\
\text { Washington DC i 2013. }\end{array}$ & \\
$\begin{array}{l}\text { Nordic Food Festival } \\
\text { Festivalområdet Det Kolde Nord } \\
\text { på Nordic Food Festival plus 2 } \\
\text { presseture for 12 journalister og } \\
\text { arrangeret tur for 8 indkøbere. }\end{array}$ & $\begin{array}{l}\text { Nordic Food festival } \\
\text { Øge kendskabet og interessen for } \\
\text { nordisk madkultur og fødevarer } \\
\text { gennem etablering af en Nordic } \\
\text { Food Festival. Desuden mere } \\
\text { fokus på udbredelse af fødevarer } \\
\text { fra det højeste nord som Island, } \\
\text { Grønland og Færøerne gennem } \\
\text { madsymposiet New Nordic Ultra. }\end{array}$ \\
& $\begin{array}{l}\text { Tidsskriftet Nordic Economic } \\
\text { Policy Review (NEPR) } \\
\text { Præsentere relevant forskning, } \\
\text { der belyser flere } \\
\text { problemstillinger, som er aktuelle } \\
\text { for den økonomiske politik i et } \\
\text { nordisk perspektiv. Fokus på } \\
\text { policy relevante analyser og } \\
\text { anbefalinger. Kommunikeres ved } \\
\text { policy seminar og udgivelse af } \\
\text { tidsskriftet. }\end{array}$ & \\
\hline
\end{tabular}

1-8011 Det blå Arktis

Programlignende aktiviteter

\begin{tabular}{|l|c|c|c|c|c|} 
Valuta & Budget 2016 & Budget 2015 & Budget 2014 & Disp./bud. 14 & Budget disp. af \\
\hline DKK & 2.500 .000 & 2.538 .000 & 0 & $0 \%$ & NSK/MR-SAM
\end{tabular}

Formål Programmet skal bidrage til at sikre en bæredygtig udvikling i arktis med landenes befolkninger i centrum. Havet er essentielt for fremtiden i Arktis, og derfor vil programmets fokus være på henholdsvis den stigende maritime aktivitet (ArcticWeb) og beskyttelsen af biodiversiteten i Ishavet. Programmet skal understøtte arbejdet i Arktisk Råd, der er det primære forum for drøftelser i og om Arktis.

Forvaltnings- Søfartsstyrelsen

organ Departement for Fiskeri, Fangst og Landbrug, Grønland

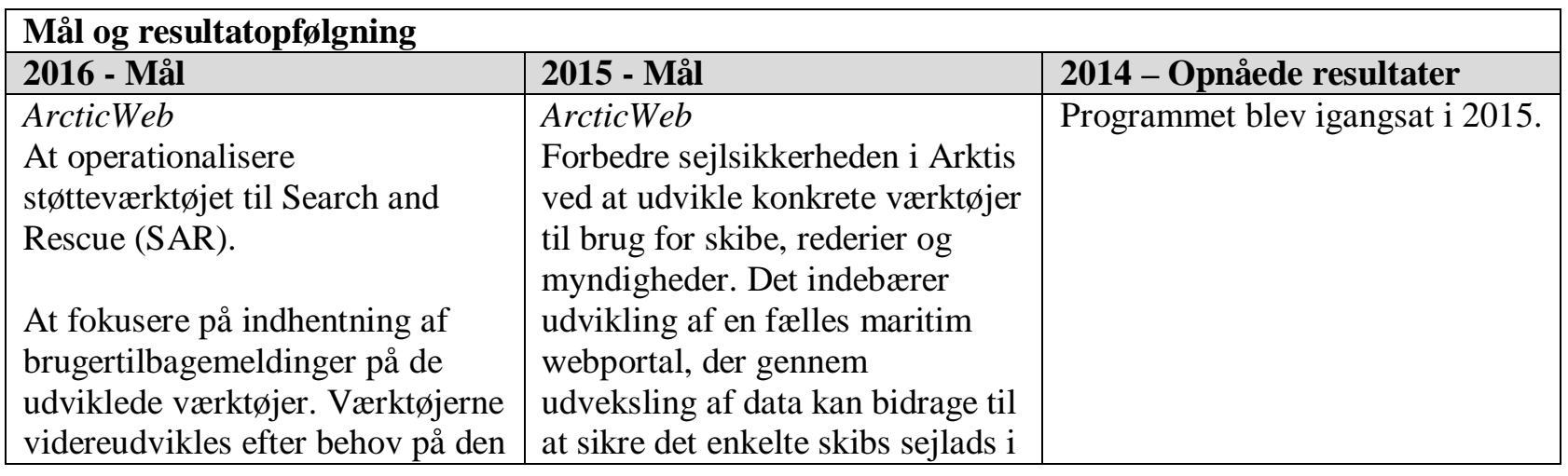


baggrund.

At fortsætte arbejdet med at udvikle en fælles maritim arktisk portal.

Havbundskortlcegning i Arktis og Nordatlanten.

At udføre tre skibssurveys ved Grønland.

At fortsætte arbejdet med dataanalyse, database og videnskabelig rapport med henblik på den fælles nordiske protokol.

dette område.

Havbundskortlcegning i Arktis og

Nordatlanten.

Projektet vil udvikle en fælles nordisk protokol til kortlægning

og monitering af havbundens biodiversitet og sårbarhed og dermed danne et bedre grundlag for Økosystembaseret Forvaltning.

Islands formandskabspulje

1-8005 Den nordiska spellistan

Programlignende aktiviteter

\begin{tabular}{|l|c|c|c|c|c|} 
Valuta & Budget 2016 & Budget 2015 & Budget 2014 & Disp./bud. 14 & Budget disp. af \\
\hline DKK & 2.000 .000 & 2.030 .000 & 2.032 .000 & $100 \%$ & MR-K
\end{tabular}

Formål Det nordiska musikexportprogrammet har som syfte att lansera nordisk musik till den nordiska allmänheten och vidare. Initiativet syftr också till att möjliggöra tillgängligheten av den nordiska spellistans innehåll, som reflekterar det som är relevant, intressant och populärt i den intranordiska regionen vid olika tidpunkter. Dessutom ska iniatiativet bidra till att öka förståelsen för konsumentbeteenden samt att respondera på dessa genom partnerskap med befintliga legala Internettjänster. Genom att göra detta kan initiativet bidra till att lyfta värdet av det nordiska varumärket och öka nordisk musik- och kulturkonsumtion.

Forvaltnings- Nordic Music Export Program (NOMEX) organ

\begin{tabular}{|c|c|c|}
\hline \multicolumn{3}{|l|}{ Mål og resultatopfølgning } \\
\hline 2016 - Mål & 2015 - Mål & 2014 - Opnåede resultater \\
\hline $\begin{array}{l}\text { Att uppdatera den nordiska spellistan } \\
\text { och vidareutveckla } \\
\text { spellistekonceptet med fler genrer } \\
\text { baserat på undersökningsresultat } \\
\text { 2015. Fortsatt internationell } \\
\text { profilering med tyngpunkt på } \\
\text { Nordamerika och Asien. } \\
\text { Identifiering av nya strömmande } \\
\text { media tjänster på marknaden, } \\
\text { inklusive den största, Beat, från } \\
\text { Apple, samt initiering av samarbete } \\
\text { med ett urval av dessa. }\end{array}$ & $\begin{array}{l}\text { Att etablera den nordiska } \\
\text { spellistan i Europa och ingå } \\
\text { partnerskap med strömmande } \\
\text { tjänster och utvalda festivaler } \\
\text { och medieverksamheter (focus } \\
\text { på Storbrittanien, Tyskland och } \\
\text { Frankrike). Fokus ligger också } \\
\text { på att utveckla exklusiva digitala } \\
\text { evenemang med relevanta } \\
\text { artister. } \\
\text { Dessutom fokuseras under } 2015\end{array}$ & $\begin{array}{l}\text { Att skapa kännedom om den } \\
\text { nordiska spellistan i den } \\
\text { nordiska regionen. } \\
\text { Att uppnå } 50000 \text { unika } \\
\text { webbsidebesök, } 7500 \\
\text { Facebook fans, } 3000 \\
\text { Twitterföljare och } 2000 \\
\text { prenumeranter på nyhetsbrevet. }\end{array}$ \\
\hline
\end{tabular}


Fortsatt dialog med alla nationella radiostationer i Norden med syfte att initiera ett pan-nordiskt musikradioprogram, och analys av tjänster med potential att utvecklas till att profilera nordiska musik över Internet. på att förbereda aktiviteter för

USA och Asien samt att

översätta den nordiska

spellistans innehåll till

aktiviteter som utvecklas på

andra kontinenter.

1-8006 Välfärdsvakten

Programlignende aktiviteter

\begin{tabular}{|l|c|c|c|c|c|} 
Valuta & Budget 2016 & Budget 2015 & Budget 2014 & Disp./bud. 14 & Budget disp. af \\
\hline DKK & 3.000 .000 & 3.045 .000 & 3.048 .000 & $100 \%$ & MR-S
\end{tabular}

Formål Projektet den nordiske velfærdsvagt skal undersøge effekterne af finanskriser på de nordiske velfærdssystemer, og hvordan de nordiske velfærdssystemer kan møde de kommende års udfordringer; specifikt indenfor helse, social og velfærd. I projektet udvikles

blandt andet indikatorer til at følge udviklingen af velfærdssystemerne i de nordiske lande, inkl. helserelaterede indikatorer. Hertil kommer en undersøgelse af, hvilket beredskab

de nordiske lande har for at møde kriser, og hvilket beredskab der mangler samt en undersøgelse af effekten af finanskriser og deres konsekvenser før velfærdssystemerne. Projektet er en del af programmet Holdbar Nordisk Velfærd.

Forvaltnings- Velfærdsministeriet i Island organ

\begin{tabular}{|c|c|c|}
\hline \multicolumn{3}{|l|}{ Mål og resultatopfølgning } \\
\hline 2016 - Mål & 2015 - Mål & 2014 - Opnåede resultater \\
\hline $\begin{array}{l}\text { Nordiske velfærdsindikatorer } \\
\text { At udarbejde et forslag til } \\
\text { nordiske velfærdsindikatorer. } \\
\text { Beredskab ved fare } \\
\text { Projektet afrapporterer analyserne } \\
\text { af fremadrettede udfordringer på } \\
\text { velfærdsområdet mv. Der vil } \\
\text { desuden indgå vurdering af } \\
\text { potentialerne i oprettelse af } \\
\text { funktioner tilsvarende den } \\
\text { islandske velfærdsvagt i forhold } \\
\text { til at håndtere krisers betydning } \\
\text { for velfærdsområdet. } \\
\text { Kriser og velfærd } \\
\text { Der skal etableres en database } \\
\text { med oplysninger om tiltag som } \\
\text { myndighederne i de nordiske } \\
\text { lande har anvendt for at } \\
\text { formindske påvirkningen af } \\
\text { kriser. }\end{array}$ & $\begin{array}{l}\text { Nordiske velfcerdsindikatorer } \\
\text { Der skal laves en første udgave af } \\
\text { Nordiske velfærdsindikatorer } \\
\text { som publiceres i } 2015 . \\
\text { Beredskab ved fare } \\
\text { Der skal gennemføres en } \\
\text { evaluering af den islandske } \\
\text { velfærdsvagt, risk mapping af de } \\
\text { største } \\
\text { udfordringer på velfærdsområdet } \\
\text { i Norden i den nærmeste fremtid } \\
\text { og en evaluering af svagheder i } \\
\text { de nordiske velfærdssystemer. } \\
\text { Kriser og velfcerd } \\
\text { Videre opbygning af en database } \\
\text { med oplysninger om handlinger } \\
\text { som myndigheder har brugt i de } \\
\text { nordiske lande for at formindske } \\
\text { Påvirkningen af kriser samt en } \\
\text { evaluering af effekt af tiltag. }\end{array}$ & $\begin{array}{l}\text { Initiativet blev på begyndt i } 2014 \\
\text { under det islandske formandskab. } \\
\text { Initiativet har tre delprojekter, } \\
\text { som alle blev etableret i } 2014 \\
\text { med projektgrupper med } \\
\text { deltagelse fra alle de nordiske } \\
\text { lande. I } 2014 \text { er desuden } \\
\text { gennemført en evaluering af den } \\
\text { islandske Velfærdsvagt. }\end{array}$ \\
\hline
\end{tabular}


1-8007 Bioekonomi-initiativet

Programlignende aktiviteter
\begin{tabular}{|l|c|c|c|c|c|} 
Valuta & Budget 2016 & Budget 2015 & Budget 2014 & Disp./bud. 14 & Budget disp. af \\
\hline DKK & 10.000 .000 & 10.150 .000 & 10.160 .000 & $98 \%$ & MR-FJLS
\end{tabular}

Formål

Satsningen på bioekonomin är en viktig del i arbetet med grön ekonomisk tillväxt och hållbarhet. Bioekonomi bygger på ett ekonomiskt system där användningen av biobaserade produkter, restprodukter och andra produkter som uppstår under bearbetningen, optimeras för att minska avfallet i värdekedjan, trycket på miljön, och maximera värdet i värdekedjan. Målet är också att göra de nya generationerna medvetna om viktigheten av grön tillväxt och hållbarhet. Det islandske ordförendeskaps bioekonomi-initiativ er et tre årigt program, som startade i 2014. Arbejdet er baseret på det Nordiska Bioekonomiinitiativet, som er initieret af MR-FJLS.

Det nordiska initiativet om bioekonomi syftar till att reducera 1) negativ miljöpåverkan och säkra hållbar användning av resurser inom alla samhällsområden, 2) reducera avfall och maximera utnyttjande och förtjänst av biologiska resurser, 3) reducera avfallsproduktion samt öka återvinningen. Härtill kommer 4) främja innovation, grönt näringsliv och regional utveckling samt 5) öka förnybar energi i transportsektoren samt förnybar energi i fiske och godstransport till sjöss. Slutligen att 6) säkra medvetenheten om grön tillväxt och hållbar utveckling i ett långsiktigt perspektiv med nya initiativer var kreativitet används som forsknings och undervisningsmetod.

Aktiviteter under bioekonomi-initiativet genomförs i perioden 2014-2016.

Forvaltnings- Satsningen är organiserad i ett flertal projekt, som förvaltas av olika institutioner, organ myndigheter och ministerier, som Landgræðsla ríkisins (Soil Conservation Services Iceland), MATIS Island, Islands Energidirektorat, Islands Skogstyrelse och Islands Utbildnings-, forsknings- och kulturministerium.

\begin{tabular}{|c|c|c|}
\hline \multicolumn{3}{|l|}{ Mål- och resultatuppföljning } \\
\hline 2016 - Mål & 2015 - Mål & 2014 - Opnåede resultater \\
\hline $\begin{array}{l}\text { Der planlægges en } \\
\text { slutkonference for NordBio i } \\
\text { 2016, hvor erfaringer, } \\
\text { resultater og } \\
\text { rekommandationer bliver } \\
\text { præsenteret og diskuteret. } \\
\text { Afslutning af } \\
\text { hovedprojekterne: Innovation } \\
\text { in the Nordic Bioeconomy, } \\
\text { WoodBio, ERMOND, Marina } \\
\text { og Biophilia. }\end{array}$ & $\begin{array}{l}\text { Realisering och etablering av den } \\
\text { nordiska bioekonomipanelen, som } \\
\text { ska anvisa strategiska möjligheter } \\
\text { och insatser för att främja hållbara } \\
\text { nordiska bioekonomier. } \\
\text { Fortsättning av projekten: } \\
\text { Innovation in the Nordic } \\
\text { Bioeconomy, WoodBio, } \\
\text { Økosystemernes modstandskraft } \\
\text { for at reducere effekter af } \\
\text { naturkatastrofer (ERMOND), } \\
\text { Marina samt Biophilia } \\
\text { Koordinera existerande nordiska } \\
\text { analyser och } \\
\text { kartläggningsaktiviteter samt } \\
\text { eventuell igångsätta nya analyser } \\
\text { och kartläggningsaktiviteter. }\end{array}$ & $\begin{array}{l}\text { Under } 2014 \text { fokuserar initiativet på } \\
\text { att stärka det nordiska } \\
\text { samarbetet kring nya initiativ med } \\
\text { tvärsektoriellt samarbete } \\
\text { inom forskning, utveckling och } \\
\text { innovation. } \\
\text { Detta ska ske i nära samarbete med } \\
\text { industri och utbildningsinstitutioner. }\end{array}$ \\
\hline
\end{tabular}


Sveriges formandskabspulje

$\underline{1-8001 \text { NordMin }}$

Programlignende aktiviteter

\begin{tabular}{|l|c|c|c|c|c|} 
Valuta & Budget 2016 & Budget 2015 & Budget 2014 & Disp./bud. 14 & Budget disp. af \\
\hline DKK & 0 & 10.150 .000 & 10.160 .000 & $98 \%$ & MR-NER
\end{tabular}

Formål NordMin ska föra samman aktörer inom den nordiska gruv- och mineralsektorn för att stärka en hållbar nordisk gruvnärings konkurrenskraft genom innovation, näringsutveckling och samverkan. NordMin ska synliggöra gruv- och mineralnäringens betydelse för en grön tillväxt i Norden. NordMin ska fungera som en forsknings- och innovationsplattform för befintliga och framtida nordiska samarbeten inom området och utformas i dialog med aktörer inom industrin, akademin och från andra berörda myndigheter.

Forvaltnings- Luleå tekniska universitet (LTU). organ

\begin{tabular}{|c|c|c|}
\hline \multicolumn{3}{|l|}{ Mål- och resultatuppföljning } \\
\hline 2016 - Mål & 2015 - Mål & 2014 - Opnåede resultater \\
\hline $\begin{array}{l}\text { Under } 2016 \text { kommer de } \\
\text { resterande överförda medlen } \\
\text { att användas till följande: } \\
\text { Genomföra workshops för } \\
\text { att } \\
\text { identifiera nyckelutmaningar } \\
\text { och samarbetsprojekt inom } \\
\text { definierade teman. } \\
\text { Avsluta och rapportera } \\
\text { resultaten från de fem } \\
\text { forsknings- och } \\
\text { innovationsprojekten inom } \\
\text { programmet. } \\
\text { Avsluta igångsatta } \\
\text { vidareutbildningsprogram } \\
\text { med gemensamma nordiska } \\
\text { kurser inom relevanta teman } \\
\text { Avsluta initierade förprojekt } \\
\text { baserade på resultaten från } \\
\text { genomförda workshops. }\end{array}$ & $\begin{array}{l}\text { Genomföra workshops för att } \\
\text { identifiera nyckelutmaningar } \\
\text { och samarbetsprojekt inom } \\
\text { definierade teman, } \\
\text { Genomföra forsknings- och } \\
\text { innovationsprojekt inom fem } \\
\text { olika program, } \\
\text { Vidareutbildningsprogram med } \\
\text { gemensamma nordiska kurser } \\
\text { inom relevanta teman, } \\
\text { Initiera förprojekt baserade på } \\
\text { resultaten från genomförda } \\
\text { workshops. }\end{array}$ & $\begin{array}{l}\text { Arbetsplan för programmet } 2013 \text { - } \\
2015 \text { är upprättad och implementerad. } \\
\text { Forsknings- och innovationsprojekt } \\
\text { inom fem olika program har startats. } \\
\text { En strategisk forsknings- och } \\
\text { innovationsagenda, plan för } \\
\text { workshopar och seminarier i syfte att } \\
\text { diskutera frågor av vikt för branschens } \\
\text { utveckling är framtagna. } \\
\text { Två workshops har genomförts i syfte } \\
\text { att skapa plattformar för post } 2016 \\
\text { samarbete inom ramen för NordMin, } \\
\text { samt att belysa aktuella frågor inom } \\
\text { gruv- och mineralnäringen. } \\
\text { Kontakter tagna med nationella } \\
\text { program och projekt som kan ansluta } \\
\text { till och utvecklas inom ramarna för } \\
\text { NordMin-programmet. } \\
\text { Utlysning av förstudieprojektmedel är } \\
\text { genomförd. } \\
\text { Arbetet med att ta fram en } \\
\text { handlingsplan för fortsatt finansiering } \\
\text { av nätverket och långsiktiga } \\
\text { prioriteringar, identifiera och bjuda in } \\
\text { fler organisationer i samarbetet har } \\
\text { inletts. }\end{array}$ \\
\hline
\end{tabular}


1-8003 Förbättrade emissionsinventeringar av kortlivade klimatpåverkande luftföroreningar

Programlignende aktiviteter
\begin{tabular}{|l|c|c|c|c|c|} 
Valuta & Budget 2016 & Budget 2015 & Budget 2014 & Disp./bud. 14 & Budget disp. af \\
\hline DKK & 0 & 2.030 .000 & 2.032 .000 & $100 \%$ & MR-M
\end{tabular}

Formål Projektet ska öka kunskapen om de faktiska utsläppen av kortlivade klimatpåverkande luftföroreningar från källor i Norden och identifiera åtgärder för att minska dessa utsläpp i de Nordiska länderna. Sotutsläpp ska särskilt studeras och det ska ges stöd till de nordiska förhandlarna om ett sotavtal inom ramen för Arktiska rådet (Task Force on Black Carbon and Methan, TFBCM).

Forvaltnings- IVL Svenska Miljöinstitutet, Sverige organ

\begin{tabular}{|c|c|c|}
\hline \multicolumn{3}{|l|}{ Mål og resultatopfølgning } \\
\hline 2016 - Mål & 2015 - Mål & 2014 - Opnåede resultater \\
\hline $\begin{array}{l}\text { Projektet är planerat avslutat med } \\
2015 .\end{array}$ & $\begin{array}{l}\text { Mätningar är klara och } \\
\text { analyserade. Resultaten ska } \\
\text { redovisas, det kommer förslag på } \\
\text { emissionsfaktorer baserat på } \\
\text { mätningarnas resultat och annan } \\
\text { information. Rekommendationer } \\
\text { för nordiska } \\
\text { emissionsinventeringar och } \\
\text { förslag på åtgärder för att minska } \\
\text { de Nordiska ländernas utsläpp av } \\
\text { kortlivade klimatpåverkande } \\
\text { luftföroreningar presenteras. }\end{array}$ & $\begin{array}{l}\text { Projektmöten har hållits löpande i } \\
\text { 2014. Ett detaljerat förslag till et } \\
\text { mätprogram har tagits fram. } \\
\text { Projektets resultat har } \\
\text { presenterats vid en workshop i } \\
\text { Gent, Belgien i regi av CLRTAP } \\
\text { Task Force on Emmission } \\
\text { Inventories and projections under } \\
\text { temaet "småskalig förbränning } \\
\text { och arbetsmaskiner". }\end{array}$ \\
\hline
\end{tabular}

1-8004 Læring på arbeidsplass (LPA)

Programlignende aktiviteter

\begin{tabular}{|l|c|c|c|c|c|} 
Valuta & Budget 2016 & Budget 2015 & Budget 2014 & Disp./bud. 14 & Budget disp. af \\
\hline DKK & 0 & 3.045 .000 & 3.048 .000 & $100 \%$ & MR-U
\end{tabular}

Formål Det 3-årige utviklingsprosjektet om læring på arbeidsplass har som formål å møte de utfordringer de nordiske landene står ovenfor knyttet til å sikre lærlinge- og praksisplasser og kvaliteten innen læring på arbeidsplass, samt å øke andelen som fullfører videregående opplæring. Prosjektet er rettet mot både ungdom og voksne.

En målsetning med prosjektet er at erfaringene blir drøftet på det nasjonale nivå, og kan bidra til økt viten og politikkutvikling på nasjonalt og nordisk nivå om læring på arbeidsplass.

Prosjektet er en del av programmet Holdbar nordisk velferd.

Forvaltnings- Statens skolverk, Sverige.

organ 


\begin{tabular}{|l|l|l|}
\hline Mål og resultatopfølgning & 2015 - Mål & 2014 - Opnåede resultater \\
\hline 2016 - Mål & $\begin{array}{l}\text { Stimulere til et utviklingsarbeid } \\
\text { om læring på arbeidsplass i Norden, } \\
\text { samt bidra til økt viten og } \\
\text { politikkutvikling på nasjonalt og } \\
\text { nords. } \\
\text { arbeidsplass. }\end{array}$ & $\begin{array}{l}\text { Gjennom prosjektet er det igangsatt } \\
\text { lokale, regionale og nasjonale } \\
\text { prosjekt i hvert land og Færøyene } \\
\text { og Âland. Mål, utfordringer og } \\
\text { resultat fra disse blir diskutert på } \\
\text { de nordiske møteplassene } \\
\text { (konferanser). }\end{array}$ \\
& $\begin{array}{l}\text { Dette finner sted gjennom } \\
\text { erfaringene fra de lokale, regionale } \\
\text { og nasjonale nivå, samt gjennom } \\
\text { totalt 7 nordiske møteplasser i } \\
\text { landene og Færøyene og Åland, } \\
\text { samt en sluttkonferanse og } \\
\text { sluttrapport. }\end{array}$ & $\begin{array}{l}\text { Det ble i 2014 gjennomført } \\
\text { møteplasser i Norge, Færøyene, } \\
\text { Island og Åland, der ideer og } \\
\text { erfaringer ble diskutert, blant annet } \\
\text { knyttet til rekruttering til yrkesfag, } \\
\text { rådgivning og karrierevalg, } \\
\text { samarbeid skole og bedrift, } \\
\text { dimensjonering, læreplasser og } \\
\text { arbeidslivets behov for kompetanse } \\
\text { i Norden. }\end{array}$ \\
& & $\begin{array}{l}\text { I tillegg til lokalt og nasjonalt } \\
\text { utviklingsarbeid, er det også initiert } \\
\text { regionalt samarbeid som for } \\
\text { eksempel innen byggområdet } \\
\text { mellom Dalarna-Värmland-Oslo- } \\
\text { Akershus. }\end{array}$ \\
&
\end{tabular}

Øvrig del af prioriteringsbudgettet

\section{$\underline{1-8110 \text { Testcenter }}$}

Projektmidler

\begin{tabular}{|l|c|c|c|c|c|} 
Valuta & Budget 2016 & Budget 2015 & Budget 2014 & Disp./bud. 14 & Budget disp. af \\
\hline DKK & 0 & 0 & 828.000 & $99 \%$ & MR-NER
\end{tabular}

Formål Projektet ska undersöka möjligheterna för att utveckla ett nordiskt samarbete omkring existerande nationella ordningar där grön energiteknologi kan testas och utvecklas i stor skala, samt undersöka möjligheterna och mervärdet av att etablera nya gemensamma nordiska test-, och demonstrationsanläggningar.

\begin{tabular}{|c|c|c|}
\hline \multicolumn{3}{|l|}{ Mål og resultatopfølgning } \\
\hline 2016 - Mål & 2015 - Mål & 2014 - Opnåede resultater \\
\hline $\begin{array}{l}\text { Programmet afsluttedes i } \\
2015 .\end{array}$ & $\begin{array}{l}\text { I } 2015 \text { vil resterende overførte } \\
\text { midler blive brugt til følgende: } \\
\text { Relevanta förslag till policy inom } \\
\text { nordiska test- och } \\
\text { demonstrationsanläggningar ska } \\
\text { utarbetas och presenteras för de } \\
\text { nordiska statsministrarna. ÄK-N och } \\
\text { ÄK-FJLS slutrapporterar projektet } \\
\text { till statsministrarna i juni } 2015 .\end{array}$ & $\begin{array}{l}\text { Projektet ska bidra till ökat fokus } \\
\text { på näringslivets behov och } \\
\text { intressen samt möjligheter att } \\
\text { realisera potentialen inom } \\
\text { bioraffinaderier. Som } \\
\text { delansvariga för projektet } \\
\text { startade ÄK-N och ÄK-FJLS upp } \\
\text { projektet under år } 2014 .\end{array}$ \\
\hline
\end{tabular}


$\underline{1-8111 \text { Uddannelse og forskning inden for grøn vækst }}$

Programlignende aktiviteter
\begin{tabular}{|l|c|c|c|c|c|} 
Valuta & Budget 2016 & Budget 2015 & Budget 2014 & Disp./bud. 14 & Budget disp. af \\
\hline DKK & 0 & 4.060 .000 & 3.759 .000 & $100 \%$ & MR-U
\end{tabular}

Formål Formålet med dette sektorprogram er at fremme børn, unge og voksnes kompetencer til at handle bæredygtigt og ressourcebevidst. Det gælder både som forbruger, som samfundsborger og som arbejdstager på fremtidens arbejdsmarked, hvor effektiv og bæredygtig udnyttelse af energi og naturressourcer i stigende grad kommer til at sætte rammerne for vækst og hverdagsliv i Norden. Gennem sektorprogrammet tilrettelægger MR-U en række undervisnings- og forskningsindsatser om bæredygtig udvikling, grønne løsninger rettet mod elever, studerende og undervisere på alle niveauer i uddannelsessystemet samt mod forsknings- og innovationsmiljøer i Norden. Indsatsen er en del af Grøn Vækst-programmet.

Forvaltnings- $\quad$ Foreningerne Nordens Forbund (FNF) organ

Voksenopplæringsforbundet/Nordisk Netværk for Voksnes Læring (NVL)

Aalto Universitet/Nordisk Netværk for Bæredygtige Universiteter

Undervisnings-, Forsknings- og Kulturministeriet i Island

NordForsk, Nordisk Energiforskning og Nordic Innovation

Centret för internationell mobilitet och internationellt samarbete (CIMO)

\begin{tabular}{|c|c|c|}
\hline \multicolumn{3}{|l|}{ Mål og resultatopfølgning } \\
\hline 2016 - Mål & 015 - Mål & 2014 - Opnåede resultater \\
\hline $\begin{array}{l}\text { I } 2016 \text { vil resterende overførte } \\
\text { midler blive brugt til følgende: } \\
\text { Klimaduellen } \\
\text { Minimum } 200 \text { deltagende skoler i } \\
\text { Klimaduellen i perioden 2015-16 } \\
\text { og en jævn fordeling af } \\
\text { deltagende skoler i mellem de } \\
\text { nordiske lande. } \\
\text { Pilotprojekt om voksnes lcering } \\
\text { Der gennemføres en faglig } \\
\text { evaluering af pilotprojektet. } \\
\text { Resultater og viden fra projektet } \\
\text { lægges til grund for en } \\
\text { videreførelse af projektet i regi af } \\
\text { efteruddannelsesinstitutioner for } \\
\text { voksenundervisere. } \\
\text { Forsknings- og } \\
\text { innovationsprogram om Grøn } \\
\text { Vcekst } \\
\text { Programmet skal udvikle ny } \\
\text { fremtidsrettet viden og innovative } \\
\text { løsninger relateret til } \\
\text { samfundsmæssige omstillinger } \\
\text { forårsaget af klimaændringer og } \\
\text { energiudfordringer, ved at bringe } \\
\text { de bedste forskere i Norden }\end{array}$ & $\begin{array}{l}\text { Styrke børn og unges bevidsthed } \\
\text { om klimaudfordringerne og } \\
\text { udvikle deres kompetencer til at } \\
\text { handle ressourcebevidst og } \\
\text { energieffektivt. } \\
\text { Målet er at mindst } 300 \text { skoler } \\
\text { deltager i den nordiske klimadag, } \\
\text { at der etableres mindst } 70 \\
\text { skolepartnerskaber omkring } \\
\text { undervisning i bæredygtig } \\
\text { udvikling og at skolerne samlet } \\
\text { sparer mindst } 2500 \text { ton CO2 som } \\
\text { følge af deltagelsen i } \\
\text { Klimadagen. } \\
\text { Udvikling af voksnes viden og } \\
\text { kompetencer om bæredygtig } \\
\text { adfcrd både som forbruger, } \\
\text { fagprofessionel og medborger. } \\
\text { I } 2015 \text { evalueres pilotprojektet } \\
\text { om uddannelsesmodul for } \\
\text { voksenundervisere om } \\
\text { bæredygtig udvikling. Målet er at } \\
\text { modulet skal kunne } \\
\text { permanentgøres og fra } 2015 \text { give } \\
\text { deltagere formel } \\
\text { studiekompetence. } \\
\text { Ruste børn og unge (0-18 år) til }\end{array}$ & $\begin{array}{l}\text { Undervisningsmateriale, temaer } \\
\text { og konkurrencer om energi, } \\
\text { klima og miljø har siden } \\
\text { november } 2014 \text { været } \\
\text { tilgængeligt på fem sprog og er } \\
\text { fuldt integreret på } \\
\text { læringsportalen Norden i Skolen. } \\
61 \text { skoler er tilmeldt og } \\
\text { konkurrencens website har haft } \\
\text { 11.000 unikke brugere. I } 2014 \\
\text { var temaet energiforbrug i fokus, } \\
\text { hvor elever skulle måle skolens } \\
\text { og hjemmets energiforbrug i } \\
\text { dagligdagen. Klimaduellen har } \\
\text { bidraget til at udvikle børn og } \\
\text { unges bevidsthed, ansvar og } \\
\text { handlekompetencer i forhold til } \\
\text { afhjælpning af klima- og } \\
\text { miljøudfordringer. } \\
\text { Nordiske } \\
\text { efteruddannelsesorganisationer } \\
\text { har lanceret en pilotuddannelse i } \\
\text { bæredygtig udvikling. I } 2015 \text { vil } \\
\text { projektet blive evalueret med } \\
\text { henblik på at afklare om } \\
\text { uddannelsen/modulet for } \\
\text { voksenundervisere kan udbydes i } \\
\text { en større skala og som et }\end{array}$ \\
\hline
\end{tabular}




\begin{tabular}{|c|c|c|}
\hline $\begin{array}{l}\text { Green Campus - Ecoliteracy } \\
\text { Mindst } 20 \text { nordiske universitete } \\
\text { deltager i projektet og } \\
\text { gennemfører test af studerendes } \\
\text { ecoliteracy inden udgangen af } \\
2016 . \\
\text { Nordic Master om Grøn Vcekst } \\
\text { At gennemføre udbud i } 2015 \text { og } \\
\text { 2016, der støtter udvikling af to } \\
\text { nordiske masterprogrammer om } \\
\text { Grøn Vækst, klima og } \\
\text { bæredygtig samfundsudvikling. }\end{array}$ & $\begin{array}{l}\text { fremtidens kompetencebehov i en } \\
\text { økonomi baseret på Grøn Vcekst. } \\
\text { Målet er at vi i Norden får mere } \\
\text { viden om, hvilke } \\
\text { undervisningsmetoder der virker i } \\
\text { forhold til at } \\
\text { fremme børn og unges } \\
\text { Understøttelse af overgangen til } \\
\text { et biobaseret samfund gennem } \\
\text { forsknings- og } \\
\text { innovationsprojekter i } \\
\text { klimaudfordringerne og } \\
\text { bioøkonomi. }\end{array}$ & $\begin{array}{l}\text { permanent efteruddannelsestilbud } \\
\text { til voksenundervisere i Norden. } \\
\text { NordForsk, Nordisk } \\
\text { Energiforskning og Nordic } \\
\text { Innovation er i } 2014 \text { gået } \\
\text { sammen om at udvikle et større } \\
\text { tværfagligt forsknings- og } \\
\text { innovationsprogram om grøn } \\
\text { vækst med titlen Green Growth - } \\
\text { Understanding Societal } \\
\text { Challenges. Programmet har et } \\
\text { samlet budget på ca. } 80 \text { MNOK } \\
\text { og skal bidrage til bred } \\
\text { anvendelse af resultater f.eks. } \\
\text { inden for uddannelse, erhvervsliv } \\
\text { og den offentlige forvaltning. } \\
\text { Biophilia-programmet har i } 2014 \\
\text { etableret distriktssamarbejder i } \\
\text { alle de nordiske lande samt } \\
\text { Alland, Færøerne og Grønland } \\
\text { omkring lokale netværk mellem } \\
\text { skoler, kulturinstitutioner og } \\
\text { forskningsmiljøer. Alle de } \\
\text { nordiske lande har i } 2014 \text { nedsat } \\
\text { en tværfaglig styregruppe og } \\
\text { udvalgt et distriktssamarbejde, } \\
\text { hvor man vil undervise i } \\
\text { Biophilia i 2015-2016. Der er } \\
\text { endvidere etableret en } \\
\text { samarbejdsplatform for forskere i } \\
\text { Norden, som skal fremme unges } \\
\text { interesse i forskning og } \\
\text { uddannelse gennem en nordisk } \\
\text { turné med forelæsninger, kurser } \\
\text { og interaktiv undervisning } \\
\text { (Videnstoget). }\end{array}$ \\
\hline
\end{tabular}

\section{1-8112 Elmarknaden}

Projektmidler

\begin{tabular}{|l|c|c|c|c|c|} 
Valuta & Budget 2016 & Budget 2015 & Budget 2014 & Disp./bud. 14 & Budget disp. af \\
\hline DKK & 0 & 1.015 .000 & 1.173 .000 & $94 \%$ & MR-NER
\end{tabular}

Formål At fremme forbrugerfleksibilitet på det nordiske elmarked gennem øget samarbejde mellem ledende aktører indenfor industri- og servicesektoren, for på den måde at dele erfaringer og best practice i forbrugerfleksibilitet og energieffektivisering.

Forvaltnings- $\quad$ Nordisk Energiforskning
organ 


\begin{tabular}{|l|l|l|}
\hline Mål og resultatopfølgning & 2015 - Mål & 2014 - Opnåede resultater \\
\hline 2016 - Mål & $\begin{array}{l}\text { Projektet afrapporteredes til } \\
\text { energiministrene ved deres } \\
\text { møde i Reykjavik 2015. } \\
\text { Ministrene besluttede at give } \\
\text { Elmarkedsgruppen i opdrag at } \\
\text { frbejde videre med } \\
\text { konklusionerne fra rapporten. } \\
\text { elektrisitetsmarked” } \\
\text { med en rapport som er behandlet i } \\
\text { elmarkedsgruppen. Rapportens } \\
\text { hovedkonklusion er, fremme af } \\
\text { forbrugerfleksibilitet bør ske i en } \\
\text { forstålse af fremtidig efterspørgsel, } \\
\text { og det derfor er vanskeligt at lave } \\
\text { en overordnet strategi. }\end{array}$ \\
& & $\begin{array}{l}\text { Forbrugerfleksibilitet behandles i } \\
\text { stedet for løbende i } \\
\text { elmarkedsgruppens arbejde. }\end{array}$ \\
\hline
\end{tabular}

$\underline{\text { 1-8113 Grønne tekniske normer og standarder - Norden som standardmaker }}$

Programlignende aktiviteter

\begin{tabular}{|l|c|c|c|c|c|} 
Valuta & Budget 2016 & Budget 2015 & Budget 2014 & Disp./bud. 14 & Budget disp. af \\
\hline DKK & 0 & 2.639 .000 & 3.251 .000 & $100 \%$ & MR-NER
\end{tabular}

Formål Del a: Formålet med indsatsen er at fjerne barrierer for handel indenfor bæredygtigt byggeri ved at koordinere tekniske normer og standarder på visse områder.

Del b: At belyse mulighederne for et øget og mere permanent nordisk samarbejde om markedskontrol af energirelaterede produkter og energimærkning. Et fælles nordisk samarbejde om markedskontrol vil bl.a. medføre støtte til de nordiske forbrugere, producenter og myndigheder i forbindelse med gennemførelsen af EU’s ecodesign- og energimærkningsdirektiver.

Forvaltnings- Del a: Nordisk Innovation og Miljømærket Svanen

organ Del b: Energimyndigheten, Sverige

\begin{tabular}{|c|c|c|}
\hline \multicolumn{3}{|l|}{ Mål og resultatopfølgning } \\
\hline 2016 - Mål & 15 - Mål & $2014-O p$ \\
\hline $\begin{array}{l}\text { Del a: I } 2016 \text { vil resterende } \\
\text { overførte midler blive brugt til } \\
\text { at udarbejde europæiske } \\
\text { standarder inden for } \\
\text { Indendørsklima og frivillige } \\
\text { klassificeringsstandarder, og } \\
\text { Holdbar renovering af } \\
\text { eksisterende bygninger. } \\
\text { Endvidere er målet at EU } \\
\text { Kommissionen bygger } \\
\text { fremtidige regulering inden for } \\
\text { Future EU regulation on } \\
\text { product and building } \\
\text { declarations på det fælles } \\
\text { nordiske indspil. }\end{array}$ & $\begin{array}{l}\text { Del a: Målet er at bidrage til at } \\
\text { iværksætte Europæiske standarder } \\
\text { indenfor de tre projektområder. } \\
\text { Dette forudsætter aktivt } \\
\text { samarbejde med Kommissionen } \\
\text { og Den Europæiske } \\
\text { Standardiseringsorganisation } \\
\text { CEN og dens } \\
\text { medlemsorganisationer, samt } \\
\text { andre vigtige stakeholders. } \\
\text { Endvidere er målet for 2015, at } \\
\text { der færdiggøres fælles nordiske } \\
\text { kriterier for svanemærkning af } \\
\text { renovering af bygninger. }\end{array}$ & $\begin{array}{l}\text { Del a: De tre arbejdsgrupper inden } \\
\text { for Indendørsklima og frivillige } \\
\text { klassificeringsstandarder, Future } \\
\text { EU regulation on product and } \\
\text { building declarations, samt } \\
\text { Holdbar renovering af } \\
\text { eksisterende bygninger } \\
\text { færdiggjorde fælles nordiske } \\
\text { indspil til en videre europæisk } \\
\text { proces. De tre fællesnordiske } \\
\text { indspil er udarbejdet på baggrund } \\
\text { af en grundig dialog og } \\
\text { høringsproces med industri og } \\
\text { forskningsinstitutioner. } \\
\text { Del b: Delprojekten Strategiska }\end{array}$ \\
\hline
\end{tabular}


Del $b$ : Programmet afsluttedes i 2015.
Del b: Projektet Challenges - hur

ska man upprätthålla god marknadskontroll av svåra, stora, komplexa produkter - genomförs. Projekten om Barriärer för marknadskontroll och Arbetsmetoder framåt slutförs. Fokus på kommunikation, publicering av resultat samt slutrapportering. Ett slutseminarium och en slutrapport för Nordsyn planeras under hösten 2015.
Nordiska Produkter-

Värmepumpar (rekommendationer

för samarbeten kring dessa produkter) och Survey SME (undersökning kunskapsläge och behov hos värmebranschen) genomfördes och rapporterades. Effekt-projektet slutfördes; resultaten visar 28 miljoner Euro i sparad energikostnad för en marknadskontrollkostnad på 2 miljoner Euro i de nordiska länderna.

\section{1-8114 Grønt offentligt indkøb}

Programlignende aktiviteter

\begin{tabular}{|l|c|c|c|c|c|} 
Valuta & Budget 2016 & Budget 2015 & Budget 2014 & Disp./bud. 14 & Budget disp. af \\
\hline DKK & 0 & 0 & 2.540 .000 & $100 \%$ & MR-NER
\end{tabular}

Formål $\quad$ Att genomföra de nordiska statsministrarnas arbetsgrupp om grön tillväxts förslag från år 2011 om en analys av ett nordiskt samarbete inom grön offentlig upphandling avseende styrmedel och inköpsstandarder.

\begin{tabular}{|c|c|c|}
\hline \multicolumn{3}{|l|}{ Mål og resultatopfølgning } \\
\hline 2016 - Mål & 2015 - Mål & 2014 - Opnåede resultater \\
\hline $\begin{array}{l}\text { I } 2016 \text { vil resterende overførte } \\
\text { midler blive brugt til følgende: } \\
\text { Projektet ska etablera ett nordiskt } \\
\text { nätverk på lokal nivå för } \\
\text { kapacitetsuppbyggnad. } \\
\text { Fokus ligger på bl.a. } \\
\text { gemensamma } \\
\text { workshops/studiebesök, utbyte av } \\
\text { kunskap och best practice samt } \\
\text { gemensamma marknadsdialoger: } \\
\text { Att ta fram gemensamma } \\
\text { riktlinjer för implementeringen } \\
\text { av de nya EU direktiven gällande } \\
\text { offentlig upphandling. } \\
\text { Att ordna ett nordiskt seminarium } \\
\text { hösten } 2016 \text { om grön tillväxt } \\
\text { genom offentlig upphandling; } \\
\text { Att ta fram långsiktig plan för } \\
\text { fortsatt nordiskt samarbete } \\
\text { mellan centrala och lokala } \\
\text { myndigheter inom ramen för grön } \\
\text { offentlig upphandling. } \\
\text { Projektet slutrapporteras i }\end{array}$ & $\begin{array}{l}\text { I } 2015 \text { vil resterende overførte } \\
\text { midler blive brugt til ÄK-N } \\
\text { behandlar en fördjupad } \\
\text { projektansökan i medlet av maj } \\
\text { 2015. Projektet ”Green growth } \\
\text { through Public Procurement” } \\
\text { inleds. } \\
\text { Under } 2015 \text { påbörjas: } \\
\text { etableringen av ett nordiskt } \\
\text { nätverk på lokal nivå för } \\
\text { kapacitetsuppbyggnad och } \\
\text { gemensamma riktlinjer för } \\
\text { implementeringen av EU } \\
\text { direktiven gällande offentlig } \\
\text { upphandling. }\end{array}$ & $\begin{array}{l}\text { För att identifiera områden och } \\
\text { produktgrupper där gröna } \\
\text { inköpsstandarder är mest } \\
\text { effektiva i förhållande till andra } \\
\text { insatser och undersöka } \\
\text { möjligheterna för att samordna } \\
\text { gröna inköpsstandarder på } \\
\text { nordisk nivå utarbetades } \\
\text { rapporten ”Status on GPP in the } \\
\text { Nordic countries”, som } \\
\text { publicerades i februari } 2014 . \\
\text { Analysen visar att Norden inte } \\
\text { uppnår fördelar med att samordna } \\
\text { gröna inköpsstandarder, eftersom } \\
\text { det redan görs på nationell och } \\
\text { EU-nivå. Däremot framhålls } \\
\text { styrkan i en gemensam nordisk } \\
\text { marknad, som ger större köpkraft } \\
\text { och möjlighet att ställa mer } \\
\text { specifika krav på produkterna. } \\
\text { Ledarskapets betydelse för } \\
\text { implementeringen av gröna } \\
\text { kriterier vid offentliga inköp lyfts } \\
\text { även fram. } \\
\text { ÄK-N beviljade 2,9 miljoner dkk } \\
\text { för projekt om grön offentlig }\end{array}$ \\
\hline
\end{tabular}




\begin{tabular}{|l|l|l|}
\hline december 2016. & $\begin{array}{l}\text { upphandling i december 2014. En } \\
\text { fördjupad projektansökan skulle } \\
\text { utarbetas och sändas till ÄK-N } \\
\text { för kommentarer. }\end{array}$ \\
\hline
\end{tabular}

\section{$\underline{\text { 1-8115 Utveckla tekniker och metoder för avfallshantering }}$}

Programlignende aktiviteter
\begin{tabular}{|l|c|c|c|c|c|} 
Valuta & Budget 2016 & Budget 2015 & Budget 2014 & Disp./bud. 14 & Budget disp. af \\
\hline DKK & 0 & 4.568 .000 & 6.736 .000 & $100 \%$ & MR-M/MR-FJLS
\end{tabular}

Formål B Både affald- og madspildsprojekterne har været en del af Grøn Vækst initiativerne som blev initieret af statsministrene.

Delprojekt vedr. affald: Projektet sigter mod at øge genbrug og genanvendelsen af materialer og samtidig kontrollere farerne ved spredning af farlige emner på tekstil- og plastaffaldsområdet. Både øget genbrug og genanvendelse har en positiv effekt på miljøet, dels gennem muligheden for at mindske CO2-udslip fra forbrænding, men frem for alt ved at genanvendte råvarer erstatter jomfruelige råvarer, hvilket resulterer i en mindskning af energi- og ressourceforbruget.

Delprojekt vedr. Madspild: Formålet er at reducere madspild uden at gå på kompromis med fødevaresikkerheden

Forvaltnings- Delprojekt vedr. Madspild: Livsmedelverket i Sverige organ Delprojekt vedr. affald: Naturvårdsverket i Sverige

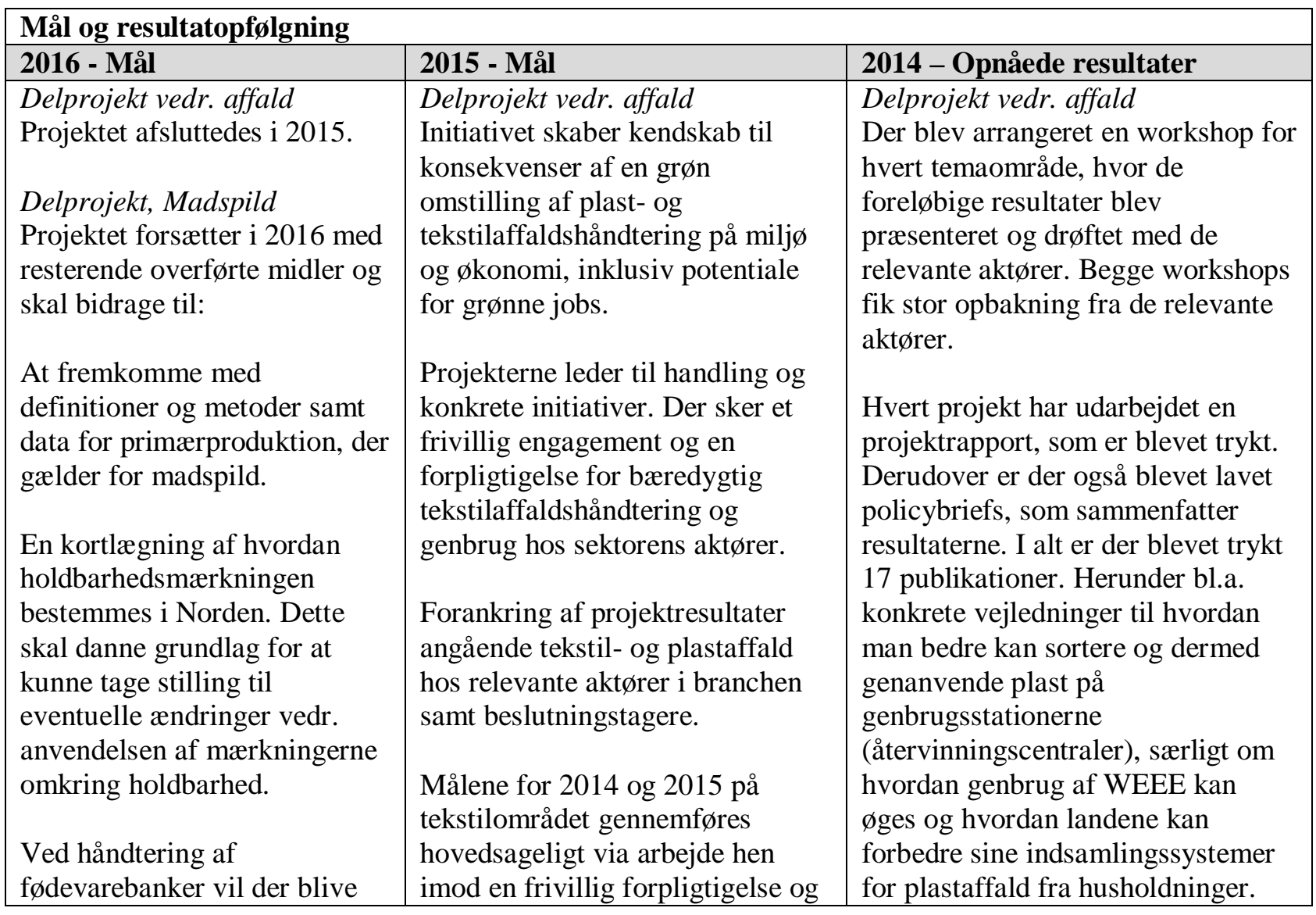




\begin{tabular}{|c|c|c|}
\hline $\begin{array}{l}\text { udvek } \\
\text { kortlæ } \\
\text { løsnin } \\
\text { Norde }\end{array}$ & $\begin{array}{l}\text { et adfærdskodeks for sektorens } \\
\text { aktører på tekstilområdet, via at } \\
\text { udarbejde et grundlag til de } \\
\text { nordiske landes beslutninger om } \\
\text { strategier indenfor indsamling, } \\
\text { sortering, genbrug og } \\
\text { genanvendelse af tekstiler samt } \\
\text { via forslag til styremiddelpakker } \\
\text { for at øge genbrug og } \\
\text { genanvendelse og skabe grønne } \\
\text { jobs indenfor } \\
\text { tekstilaffaldsområdet. På } \\
\text { plastområdet inkluderer de } \\
\text { konkrete aktiviteter blandt andet } \\
\text { udvikling af vejledninger for } \\
\text { indsamling af plastemballage fra } \\
\text { husholdninger optimering af } \\
\text { WEEE-plast værdikæden i } \\
\text { forhold til både genanvendelse og } \\
\text { håndtering af farlige stoffer, } \\
\text { sortering af plastaffald på } \\
\text { genbrugsstationer } \\
\text { (återvinningscentraler). } \\
\text { Delprojekt, Madspild } \\
\text { Fremkomme med definitioner og } \\
\text { metoder samt data for } \\
\text { primærproduktion, der gælder for } \\
\text { madspild. } \\
\text { En kortlægning af hvordan } \\
\text { holdbarhedsmærkningen } \\
\text { bestemmes i Norden. Dette skal } \\
\text { danne grundlag for at kunne tage } \\
\text { stilling til eventuelle ændringer } \\
\text { vedr. anvendelsen af } \\
\text { mærkningerne omkring } \\
\text { holdbarhed. } \\
\text { Ved håndtering af fødevarebanker } \\
\text { vil der blive udvekslet erfaringer } \\
\text { og ske en kortlægning af de } \\
\text { forskellige løsninger, der bliver } \\
\text { gjort i Norden. }\end{array}$ & $\begin{array}{l}\text { For at bidrage til en øget } \\
\text { genanvendelse og øget } \\
\text { materialegenanvendelse af tekstil er } \\
\text { der udviklet et certificeringssystem } \\
\text { for aktører der indsamler og sorterer } \\
\text { tekstil, forskellige mulige } \\
\text { styremidler og nye } \\
\text { forretningsmodeller er blevet } \\
\text { sammenstillet og analyseret } \\
\text { derudover er der udviklet en fælles } \\
\text { nordisk strategi med konkrete } \\
\text { handlinger for de forskellige } \\
\text { aktører. Resultaterne viser et } \\
\text { potentiale på over } 4000 \text { nye grønne } \\
\text { jobs, som kan skabes i } \\
\text { tekstilbranchen i Norden samtidig } \\
\text { med at miljøpåvirkningen af } \\
\text { tekstilkonsumtionen mindskes og } \\
\text { Nordens konkurrencekraft øges. } \\
\\
\text { Delprojekt, Madspild } \\
\text { Fremkomme med definitioner og } \\
\text { metoder samt data for } \\
\text { primærproduktion, der gælder for } \\
\text { madspild. Der er blevet arbejdet for } \\
\text { enslydende definitioner og } \\
\text { anvendelse af samme metodik i } \\
\text { Norden med udgangspunkt i det } \\
\text { arbejde, der foregår indenfor det } \\
\text { EU-finansierede forskningsprojekt } \\
\text { FUSIONS. } \\
\text { En kortlægning af hvordan } \\
\text { holdbarhedsmærkningen bestemmes } \\
\text { i Norden. Dette skal danne grundlag } \\
\text { for at kunne tage stilling til } \\
\text { eventuelle ændringer vedr. } \\
\text { anvendelsen af mærkningerne } \\
\text { omkring holdbarhed. Der er } \\
\text { udgivet en rapport vedr. denne } \\
\text { kortlægning og den er bl.a. blevet } \\
\text { anvendt som et bidrag til } \\
\text { retningslinjerne i EU på området. } \\
\text { Ved håndtering af fødevarebanker } \\
\text { er der sket en udveksling af } \\
\text { erfaringer og en kortlægning af de } \\
\text { forskellige løsninger, der bliver } \\
\text { gjort i Norden. Der er udgivet en } \\
\text { rapport, der også har givet } \\
\text { inspiration til det arbejder der } \\
\text { foregår i EU-regi. }\end{array}$ \\
\hline
\end{tabular}


1-8116 Främja integration av miljö och klimat i utvecklingssamarbetet

Projektmidler
\begin{tabular}{|l|c|c|c|c|c|} 
Valuta & Budget 2016 & Budget 2015 & Budget 2014 & Disp./bud. 14 & Budget disp. af \\
\hline DKK & 0 & 508.000 & 508.000 & $100 \%$ & MR-M
\end{tabular}

Formål Projektets formål er at fremme integreringen af miljø og klima i udviklingssamarbejdet. Opgaven ligger udenfor det formaliserede nordiske samarbejde, idet udviklingssamarbejde hører under udenrigsministrene. I ekspertgruppen for projektet indgår således repræsentanter fra udenrigsministerierne i de forskellige nordiske lande.

Forvaltnings- Global Subsidies Initiative (GSI), International Institute for Sustainable Deveolpment organ (IISD), Geneve.

\begin{tabular}{|c|c|c|}
\hline \multicolumn{3}{|l|}{ Mål og resultatopfølgning } \\
\hline 2016 - Mål & 2015 - Mål & 2014 - Opnåede resultater \\
\hline Projektet afsluttedes i 2015. & $\begin{array}{l}\text { Præsentere projektets resultater i } \\
\text { relevante fora, herunder bl.a. de } \\
\text { forberedende møder til FN’s } \\
\text { klimakonferencer i Paris } 2015 \\
\text { (COP21). Samt følge op og } \\
\text { justere rekommandationerne til } \\
\text { relevante fora. }\end{array}$ & $\begin{array}{l}\text { Resultaterne fra projektet indikerer, } \\
\text { at en reformering af subsidierne kan } \\
\text { reducere den globale CO2- } \\
\text { udledning med op til mellem } 6 \text { og - } \\
13 \text { \% inden 2050. Projektet har } \\
\text { leveret en række vigtige konkrete } \\
\text { og operationelle resultater, som } \\
\text { hver især bidrager direkte til } \\
\text { arbejdet med udfasningen af } \\
\text { statsstøttede fossile brændsler, } \\
\text { hvilet omfatter en beregningsmodel, } \\
\text { som gør det muligt at kalkulere, } \\
\text { hvor meget udviklingslandene kan } \\
\text { reducere deres emissioner ved at } \\
\text { udfase statsstøtten til fossile } \\
\text { brændsler. Dertil kommer en } \\
\text { teoretisk baggrundsrapport udgivet i } \\
\text { 2014, som beskriver mulighederne } \\
\text { for et tættere nordisk samarbejde } \\
\text { om omlægningen af subsidier til } \\
\text { fossile brændsler. Desuden er der } \\
\text { blevet udarbejdet en ”How to - } \\
\text { guidebook”, som operationaliserer } \\
\text { ovenstående data og viden og } \\
\text { hjælper landene til helt konkret at } \\
\text { indregne det individuelle lands } \\
\text { budgetterede reduktioner i CO2- } \\
\text { udledninger ved at reformere } \\
\text { statsstøttesystemet til fossile } \\
\text { brændsler projektdesign. } \\
\text { Projektresultaterne er } \\
\text { kommunikeret og anvendt i } \\
\text { forbindelse med en række } \\
\text { internationale klimaforhandlinger, } \\
\text { bl.a. COP20 i Lima og UNFCCC’s } \\
\text { klimakonferencer i } 2014 .\end{array}$ \\
\hline
\end{tabular}


1-8118 Särskilda prioriteringer Grön tillväxt

Projektmidler
\begin{tabular}{|l|c|c|c|c|c|} 
Valuta & Budget 2016 & Budget 2015 & Budget 2014 & Disp./bud. 14 & Budget disp. af \\
\hline DKK & 0 & 406.000 & 499.000 & $100 \%$ & Generalsekretæren
\end{tabular}

Formål $\quad$ Formålet er at profilere de nordiske lande som ledende indenfor grøn vækst og øge kendskabet til nordiske grønne løsninger både i Norden og internationalt. Indsatsen er en del af Grøn Vækst-programmet.

\begin{tabular}{|c|c|c|}
\hline \multicolumn{3}{|l|}{ Mål og resultatopfølgning } \\
\hline 2016 - Mål & 2015 - Mål & 2014 - Opnåede resultater \\
\hline $\begin{array}{l}\text { I } 2016 \text { vil resterende overførte } \\
\text { midler blive brugt til at formidle } \\
\text { slutresultater fra det samlede } \\
\text { initiativ, inklusive en } \\
\text { afslutningskonference i foråret } \\
2016 \text { med centrale stakeholders. } \\
\text { Grøn vækst programmet } \\
\text { slutrapporteres som helhed til } \\
\text { de nordiske statsministre i } 2016 .\end{array}$ & $\begin{array}{l}\text { Styrke arbejdet med } \\
\text { webmagasinet "Green Growth the } \\
\text { Nordic Way” samt øge } \\
\text { kommunikationsoutput fra de } \\
\text { enkelte projektledere. } \\
\text { Endvidere sikre formidling af } \\
\text { resultater fra initiativet som en del } \\
\text { af NMRs samlede kommunikation } \\
\text { op mod COP21, inklusive } \\
\text { deltagelse på UNFCCC i Bonn i } \\
\text { juni, SDG Summit i New York i } \\
\text { september og World Efficiency i } \\
\text { Paris i oktober. } \\
\text { Hertil kommer formidling af } \\
\text { resultater af de projekter, som har } \\
\text { relevans ift cirkulær økonomi } \\
\text { dagsordenen på World Ressource } \\
\text { Forum i Davos i oktober. } \\
\text { En samlet rapport om } \\
\text { programmets status fremlægges } \\
\text { for de nordiske statsministre i } \\
2015 .\end{array}$ & $\begin{array}{l}\text { Yderligere etablering af } \\
\text { webmagasinet "Green Growth the } \\
\text { Nordic Way” som kanal for at } \\
\text { kommunikere statsministrenes } \\
\text { grøn vækst initiativ samt det } \\
\text { nordiske samarbejde om } \\
\text { bæredygtig udvikling og } \\
\text { bioøkonomi i bred forstand. } \\
\text { Ved årets slut var der knap } 1000 \\
\text { abonnenter, fra over } 20 \text { lande og } \\
\text { mere end } 10 \text { IGOs, hvilket var } \\
\text { målsætningen. Der arbejdes } \\
\text { målrettet med at placere de } \\
\text { individuelle artikler i andre } \\
\text { udgivelser og hver artikel kommer } \\
\text { ud vi mindst } 5 \text { andre kanaler. En } \\
\text { evaluering viste stor tilfredshed } \\
\text { blandt læserne (karakter } 5 \text { ud af } 7 \text { ) } \\
\text { og NMR som kilde vurderes som } \\
\text { værende meget troværdig } \\
\text { (karakter } 6 \text { ud af 7). } \\
\text { Endvidere vellykket deltagelse på } \\
\text { EU Kommissionens Green Week, } \\
\text { samt velbesøgt } \\
\text { kommunikationskursus afholdt for } \\
\text { projektlederne med henblik på at } \\
\text { styrke de enkelte projekters egen } \\
\text { kommunikationsindsats. } \\
\text { Efterfølgende har flere af } \\
\text { projekterne af egen drift haft avis } \\
\text { og TV indslag. }\end{array}$ \\
\hline
\end{tabular}


1-8210 Hållbar nordisk välfärd

Programlignende aktiviteter
\begin{tabular}{|l|c|c|c|c|c|} 
Valuta & Budget 2016 & Budget 2015 & Budget 2014 & Disp./bud. 14 & Budget disp. af \\
\hline DKK & 0 & 11.165 .000 & 13.208 .000 & $85 \%$ & MR-S/MR-U
\end{tabular}

Formål Programmet Hållbar nordisk välfärd syftar till att hitta innovativa lösningar för att förnya de nordiska välfärdssamfunden för Nordens 25 miljoner invånare. Lösningarna ska

bidra till ökad kvalitet och jämlikhet i utbildning, arbete, hälsa och omsorg. Detta uppnås genom finansiering av konkreta insatser och skapandet av nordiska plattformar för

dialog och kunskapsutbyte. De lösningar som tas fram inom ramen för programmet synliggörs och profileras i och utanför Norden.

Programmets mål ska realiseras genom konkreta projekt och aktiviteter inom tre insatsområden: 1. Utbildning och arbete för välfärd, 2. Forskning för välfärd och 3. Infrastruktur för välfärd.

Programmet gäller för perioden 2013 - 2015.

Forvaltnings- Programmet är organiserat i ett flertal projekt, som förvaltas av olika institutioner, organ myndigheter, privata företag och konsulter, som t.ex. Statens skolverk i Sverige, Nordens Välfärdscenter och NordForsk. Nordiska ministerrådet leder och koordinerar programmet och dess tvärgående aktiviteter inom programmets tre insatsområden.

\begin{tabular}{|c|c|c|}
\hline \multicolumn{3}{|l|}{ Mål og resultatopfølgning } \\
\hline 2016 - Mål & 2015 - Mål & 2014 - Opnåede resultater \\
\hline $\begin{array}{l}\text { Programmet Hållbar nordisk } \\
\text { välfärd slutrapporteres som } \\
\text { helhed til de nordiske } \\
\text { statsministre i } 2016 \text {. }\end{array}$ & $\begin{array}{l}\text { Presentera och sprida resultat } \\
\text { och konkreta lösningsförslag } \\
\text { inom programmets tre } \\
\text { insatsområden och de enskilda } \\
\text { projekten, } \\
\text { för att på så sätt bidra till } \\
\text { kunskapsutbyte inom Norden. } \\
\text { Följa upp Könberg-rapporten } \\
\text { om det framtida nordiska } \\
\text { hälsosamarbetet. } \\
\text { Bedöma om och hur olika resultat } \\
\text { bör vidareföras nordiskt, } \\
\text { nationellt och eventuellt profileras } \\
\text { utanför Norden. }\end{array}$ & $\begin{array}{l}\text { Sammanlagt } 18 \text { projekt har satts } \\
\text { igång och dessa utvecklas som } \\
\text { planerat. } \\
\text { I september } 2014 \text { genomfördes det } \\
\text { en halvvägs-konferens för } \\
\text { programmet som fokuserade på } \\
\text { preliminära resultat och } \\
\text { kunskapsspridning. Konferensen } \\
\text { var en fortsättning på } \\
\text { lanseringskonferensen som } \\
\text { genomfördes i augusti 2013. } \\
\text { Målgruppen för dessa arrangemang } \\
\text { har varit kontaktpersoner från } \\
\text { länderna, projektledare, medlemmar } \\
\text { i ämbetsmannakommittéer samt } \\
\text { andra nordiska aktörer. Vidare har } \\
\text { det avhållits diverse seminarier och } \\
\text { workshops inom de olika projekten, } \\
\text { eller tvärsgående mellan projekt, } \\
\text { bl.a. våren } 2014 \text { då det genomfördes } \\
\text { nationella seminarier i varje land } \\
\text { (undantaget Danmark) där } \\
\text { programmet och de enskilda } \\
\text { projekten blev presenterade och } \\
\text { diskuterades. }\end{array}$ \\
\hline
\end{tabular}




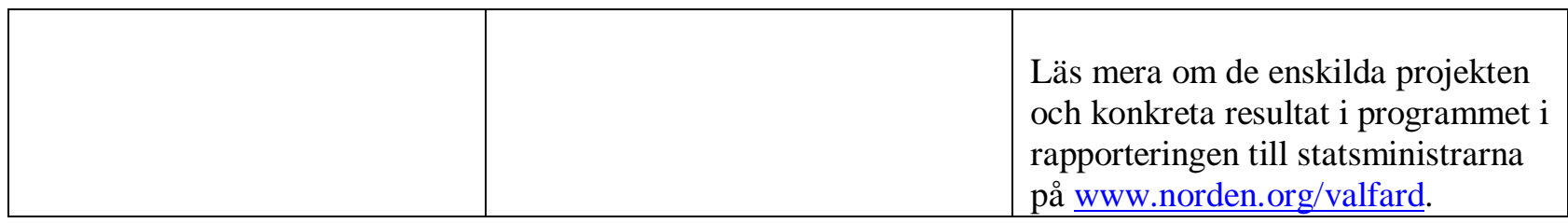

$\underline{1-8212 \text { Välfärd och kost }}$

Programlignende aktiviteter

\begin{tabular}{|l|c|c|c|c|c|} 
Valuta & Budget 2016 & Budget 2015 & Budget 2014 & Disp./bud. 14 & Budget disp. af \\
\hline DKK & 0 & 785.000 & 1.016 .000 & $98 \%$ & MR-FLJS
\end{tabular}

Formål $\quad$ Formålet er at implementere den nordiske handlingsplan for bedre sundhed og livskvalitet gennem kost og fysisk aktivitet

\begin{tabular}{|l|l|l|}
\hline Mål og resultatopfølgning & 2015 - Mål & 2014 - Opnåede resultater \\
\hline 2016 - Mål & $\begin{array}{l}\text { Selve fejringen af 5 års jubilæum } \\
\text { for nøglehulsmærket skete på en } \\
\text { vellykket dag i Stockholm, hvor de } \\
\text { forskellige lande fremlagde status, }\end{array}$ & $\begin{array}{l}\text { Der blev sat fokus op } \\
\text { kommunikation af de nordiske } \\
\text { næringsstofanbefalinger, } \\
\text { herunder forbrugerundersøgelser } \\
\text { herunder igennem analyser og } \\
\text { samarbejde med det nordiske } \\
\text { ernæringsmærke, nøglehullet. }\end{array}$ \\
& og udbredelse af anvendelse af \\
& mærket. Herunder var der også \\
& fokus på evidens og effekt af det \\
nordiske ernæringsmærke. & \\
\hline
\end{tabular}

\section{$\underline{1-8310 \text { Klimavenligt byggeri }}$}

Programlignende aktiviteter

\begin{tabular}{|l|c|c|c|c|c|} 
Valuta & Budget 2016 & Budget 2015 & Budget 2014 & Disp./bud. 14 & Budget disp. af \\
\hline DKK & 0 & 0 & 5.690 .000 & $100 \%$ & EK-NER
\end{tabular}

Formål Det fællesnordiske innovationsprogram for klimavenligt byggeri skal styrke Norden som foregangsregion indenfor klimavenligt byggeri, og være med til at sikre innovation, vækst og eksport på området. Programmet skal have en tæt tilknytning til markedet, og være i samspil med nationale programmer og satsninger på området.

\begin{tabular}{|c|c|c|}
\hline \multicolumn{3}{|l|}{ Mål og resultatopfølgning } \\
\hline 2016 - Mål & 2015 - Mål & 2014 - Opnåede resultater \\
\hline $\begin{array}{l}\text { Programmet afsluttedes i } \\
2014 .\end{array}$ & Programmet afsluttedes i 2014. & $\begin{array}{l}\text { I } 2014 \text { gennemførtes et call for } \\
\text { proposals indenfor forretningsmodeller, } \\
\text { demonstration og eksport. } 13 \text { projekter } \\
\text { fik støtte. } \\
\text { Programmet har også været med til at } \\
\text { starte det nordiske showroom i Masdar } \\
\text { City som skal sætte fokus på eksport af } \\
\text { nordisk byggeri. Showroomet åbende i } \\
\text { februar } 2015 \text {. }\end{array}$ \\
\hline
\end{tabular}




\begin{tabular}{|l|l|}
\hline & $\begin{array}{l}\text { Programmet er afsluttet og har leveret } \\
\text { input til programmet NordicBuild } \\
\text { Cities. }\end{array}$ \\
\hline
\end{tabular}

1-8311 Kultur og kreativitet - KreaNord initiativet

Programlignende aktiviteter

\begin{tabular}{|l|c|c|c|c|c|} 
Valuta & Budget 2016 & Budget 2015 & Budget 2014 & Disp./bud. 14 & Budget disp. af \\
\hline DKK & 0 & 0 & 4.064 .000 & $95 \%$ & EK-NER/MR-K
\end{tabular}

Formål KreaNord startede i 2008 som et globaliseringsinitiativ og har været et tværfagligt nordisk program mellem erhvervssektoren og kultursektoren. Formålet har været at styrke vækstmulighederne og beskæftigelsen i de kulturelle og kreative erhverv i Norden.

KreaNords virksomhed blev afviklet i 2015, med økonomisk støtte fra MR-NER og MR-K, hvor der blev foretaget en evaluering af KreaNord, afholdt et afsluttende arrangement og den sidste projektvirksomhed gennemførtes.

\begin{tabular}{|c|c|c|}
\hline \multicolumn{3}{|l|}{ Mål og resultatopfølgning } \\
\hline 2016 - Mål & 2015 - Mål & 2014 - Opnåede resultater \\
\hline $\begin{array}{l}\text { Programmet afsluttedes i } \\
2015 .\end{array}$ & $\begin{array}{l}\text { I } 2015 \text { var målet at integrere KreaNord } \\
\text { i den ordinære virksomhed eller } \\
\text { videreføre det i andre nordiske } \\
\text { initiativer. Som en del af KreaNords } \\
\text { afviklingsplan var målet derfor at } \\
\text { evaluere hele programmet og afholde et } \\
\text { afsluttende arrangement som kunne } \\
\text { synliggøre resultaterne, og spille ind i } \\
\text { erhvervssektorens fortsatte arbejde med } \\
\text { kulturelle og kreative erhverv. }\end{array}$ & $\begin{array}{l}\text { I } 2014 \text { gennemførte KreaNord } \\
\text { projekter med fokus på } \\
\text { entreprenørskab, finansiering, } \\
\text { erfaringsudveksling og } \\
\text { tværfagligt samarbejde i Norden } \\
\text { inden for kulturelle og kreative } \\
\text { erhverv. Indsatserne har bidraget } \\
\text { til arbejdet med at opfylde } \\
\text { KreaNords fire policy } \\
\text { anbefalinger besluttet af MR- } \\
\text { NER og MR-K i } 2010 .\end{array}$ \\
\hline
\end{tabular}

$\underline{\text { 1-8312 Offentligt-privat-partnerskab om planteforædling i Norden }}$

Programlignende aktiviteter

\begin{tabular}{|l|c|c|c|c|c|} 
Valuta & Budget 2016 & Budget 2015 & Budget 2014 & Disp./bud. 14 & Budget disp. af \\
\hline DKK & 0 & 0 & 508.000 & $100 \%$ & MR-FJLS
\end{tabular}

Formål $\quad$ MR-FJLS igangsatte i 2011 et offentligt-privat partnerskab om planteforædling i

Norden. Formålet med partnerskabet er, at revitalisere den nordiske planteforædling for at styrke landenes tilpasning til klimaforandringer og er samtidig et væsentligt element $\mathrm{i}$ ministerrådets arbejde med bioøkonomi. Målet med budgetposten er, at sikre 50 \% fra landene og $50 \%$ fra virksomhederne. Sekretariatsbetjeningen af partnerskabet varetages af NordGen.

Forvaltnings- NordGen

organ 


\begin{tabular}{|l|l|l|}
\hline Mål og resultatopfølgning & 2015 - Mål & 2014 - Opnåede resultater \\
\hline 2016 - Mål & Programmet afsluttedes i 2014. & $\begin{array}{l}\text { Projektets tema fik bla. fremgang ved } \\
\text { et vellykket seminar, hvor deltagere i } \\
\text { det allerede etablerede partnerskab } \\
\text { lagde grunden til en videreførelse af } \\
\text { arbejdet i 2015 og fremad. På MR- } \\
\text { FJLS blev landene enige om at } \\
\text { fortsætte finansieringen af } \\
\text { partnerskabet under egne } \\
\text { budgetposter. }\end{array}$ \\
\hline
\end{tabular}

\section{1-8313 Ny Nordisk Mad}

Programlignende aktiviteter

\begin{tabular}{|l|c|c|c|c|c|} 
Valuta & Budget 2016 & Budget 2015 & Budget 2014 & Disp./bud. 14 & Budget disp. af \\
\hline DKK & 0 & 0 & 508.000 & $100 \%$ & MR-FLJS
\end{tabular}

Formål $\quad$ Ny Nordisk Mad er en konkret og værdiskabende og innovativ satsning, der med udgangspunkt i Manifest for et nyt nordisk køkken, har til formål, at styrke det tværsektorielle samarbejde, som favner mad, kultur, kreative industrier, turisme og erhverv med henblik på at skave ny inspiration. Indsatsen under denne budgetpost relaterer sig til budgetpost 5-6420 Ny Nordisk Mad under MR-FJLS, og skal bidrage til at synliggøre det nordiske arbejde med Ny Nordisk Mad i og uden for Norden.

\begin{tabular}{|l|l|l|}
\hline Mål og resultatopfølgning & 2015 - Mål & 2014 - Opnåede resultater \\
\hline 2016 - Mål & Programmet afsluttedes i 2014. & $\begin{array}{l}\text { Aret 2014 var det sidste år i } \\
\text { programperioden 2010-2014 hvilket } \\
\text { medførte at stor del af aktiviteterne } \\
\text { bestod i at runde af og afklare } \\
\text { hvordan visse aktiviteter inden for } \\
\text { programmet kunne fortsættes i } \\
\text { samarbejde mellem landene. Det } \\
\text { handler især om branding af } \\
\text { nordiske fødevarer og videreførelse } \\
\text { af den omfattende netværksaktivitet } \\
\text { som er blevet opbygget inden for } \\
\text { Ny Nordisk Mad. }\end{array}$ \\
& & $\begin{array}{l}\text { En slutrapport forventes til midten } \\
\text { af maj 2015. }\end{array}$ \\
\hline
\end{tabular}


$\underline{\text { 1-8410 Politiska prioriteringar }}$

Projektmidler
\begin{tabular}{|l|c|c|c|c|c|} 
Valuta & Budget 2016 & Budget 2015 & Budget 2014 & Disp./bud. 14 & Budget disp. af \\
\hline DKK & 6.000 .000 & 3.553 .000 & 0 & $0 \%$ & NSK/MR-SAM
\end{tabular}

Formål

I overensstemmelse med moderniseringsrapporten Nyt Norden skal Nordisk Ministerråd regelmæssigt og inden for udvalgte sektorer udrede muligheden for udvikling af det politiske samarbejde ligesom man har gjort i en udredning af tidligere svensk minister Bo Könberg på sundhedsområdet og gennemlysningen af arbejdslivssektoren der blev iværksat i 2015. Formålet er at identificere hvor det største potentiale for nordisk samarbejde inden for en sektor ligger.

Budgetposten kan anvendes til at delfinansiere en egentlig udredning samt den indledende fase af opfølgningen på en udredning. Delfinansieringen bør dog ledsages af finansiering fra den respektive sektor. Sektorfinansieringen bør afhænge af størrelsen på sektorens budget.

Der er ikke tale om en længerevarende eller fast delfinansiering af nye indsatser som følger af en udredning af en sektor.

\section{Mål og resultatopfølgning}

\begin{tabular}{|l|l|l|}
\hline 2016 - Mål & 2015 - Mål & 2014 - Opnåede resultater \\
\hline $\begin{array}{l}\text { I } 2016 \text { vil midlerne fra denne post } \\
\text { først og fremmest gå til opfølgning } \\
\text { på anbefalinger fra udredningen af } \\
\text { arbejdslivssektoren der er udført i } \\
\text { løbet af 2015 samt opfølgning af } \\
\begin{array}{l}\text { Könberg-rapporten i social- og } \\
\text { helsesektoren. }\end{array}\end{array}$ & $\begin{array}{l}\text { I 2015 delfinansieres } \\
\text { opfølgningen af den uafhængige } \\
\text { udredning af sundhedssektoren } \\
\text { med ca. 3 MDKK. }\end{array}$ & $\begin{array}{l}\text { Budgetposten blev oprettet i } \\
2015 .\end{array}$ \\
$\begin{array}{l}\text { I 2015 delfinansieres desuden } \\
\text { gennemlysningen af } \\
\text { en ny vektor til en strategisk } \\
\text { gennemlysning og arbejdet med } \\
\text { gennemlysningsektoren med ca. 0,5 } \\
\text { MDKK. }\end{array}$ & \\
\hline
\end{tabular}

1-8411 Politiske initiativer i nærområderne

Projektmidler
\begin{tabular}{|l|c|c|c|c|c|} 
Valuta & Budget 2016 & Budget 2015 & Budget 2014 & Disp./bud. 14 & Budget disp. af \\
\hline DKK & 3.375 .000 & 0 & 0 & $0 \%$ & NSK/MR-SAM
\end{tabular}

Formål Som følge af MR-SAM’s beslutning om at afvikle virksomheden på Nordisk Ministerråds informationskontor i Nordvestrusland på ubestemt tid - og i lyset af den politiske udvikling i Nordens nærområder - vurderes det relevant under prioriteringsbudgettet at afsætte midler til andre målrettede politiske initiativer i Nordens nærområder.

\begin{tabular}{|l|l|l|}
\hline Mål og resultatopfølgning \\
\hline 2016 - Mål & 2015 - Mål & 2014 - Opnåede resultater \\
\hline Budgetposten vil give mulighed & Programmet blev igangsat i 2016. & Programmet blev igangsat i 2016. \\
\hline
\end{tabular}


for at imødekomme forslag til

initiativer, som er politisk

forankrede i landene.

\section{1-8420 Profilering og positionering}

Projektmidler

\begin{tabular}{|l|c|c|c|c|c|} 
Valuta & Budget 2016 & Budget 2015 & Budget 2014 & Disp./bud. 14 & Budget disp. af \\
\hline DKK & 10.000 .000 & 0 & 0 & $0 \%$ & NSK/MR-SAM
\end{tabular}

Formål

Nordisk Ministerråds arbejde vedr. international profilering og positionering af Norden følger op på Strategi for international profilering og positionering af Norden, vedtaget af Samarbejdsministrene i oktober 2014. Formålet er i fællesskab at styrke Nordens og de nordiske landes konkurrenceevne og internationale indflydelse gennem samordnede profilerende aktiviteter. Budgetposten skal i tråd med den vedtagne strategi bruges med sigte på medfinansiering fra forskellige samarbejdspartnere.

\begin{tabular}{|c|c|c|}
\hline \multicolumn{3}{|l|}{ Mål og resultatopfølgning } \\
\hline 2016 - Mål & 2015 - Mål & 2014 - Opnåede resultater \\
\hline $\begin{array}{l}\text { Omsætte Strategi for } \\
\text { international profilering og } \\
\text { positionering af Norden til visuel } \\
\text { synlighed gennem målrettede } \\
\text { aktiviteter, fx strategi for digital } \\
\text { tilstedeværelse og udvikling af } \\
\text { visuel identitet. }\end{array}$ & $\begin{array}{l}\text { Via en omfordeling af midler fra } \\
\text { Budgetpost } 2020 \\
\text { Globaliseringsforum blev der i } \\
2015 \text { prioriteret } 1 \text { mio. kr. til } \\
\text { internationalt profileringsarbejde } \\
\text { under budgetpost } 1 \text { - } \\
\text { 8410/Politiske prioriteringer. }\end{array}$ & \\
\hline $\begin{array}{l}\text { Bidrage til og styrke synlighed og } \\
\text { opmærksomhed omkring Norden, } \\
\text { gennem tilstedeværelse på } \\
\text { arrangementer/events, der } \\
\text { udvælges i samarbejde med } \\
\text { referencegruppen for profilering } \\
\text { og positionering af Norden. } \\
\text { Skabe større opmærksomhed } \\
\text { omkring Norden gennem } \\
\text { udvikling af egne profilerende } \\
\text { aktiviteter. }\end{array}$ & $\begin{array}{l}\text { Målet for profileringsstrategiens } \\
\text { første år har været at påbegynde } \\
\text { implementeringen af strategien } \\
\text { internt i det nordiske samarbejde, } \\
\text { samt eksternt i forhold til } \\
\text { samarbejdspartnere. } \\
\text { Under overskriften New Nordic } \\
\text { Climate Solutions gennemføres et } \\
\text { pilotprojekt for profilerings- og } \\
\text { positioneringsarbejdet, i form af } \\
\text { et internationalt fremstød for } \\
\text { nordiske klima-, bæredygtigheds- } \\
\text { og grønne løsninger. }\end{array}$ & \\
\hline
\end{tabular}


$\underline{1-8510 \text { Nye tværgående initiativer }}$

Programlignende aktiviteter

\begin{tabular}{|l|c|c|c|c|c|} 
Valuta & Budget 2016 & Budget 2015 & Budget 2014 & Disp./bud. 14 & Budget disp. af \\
\hline DKK & 10.000 .000 & 0 & 0 & $0 \%$ & NSK/MR-SAM
\end{tabular}

Formål Denne budgetpost bidrager til at muliggøre igangsættelse af nye og større tematiserede satsninger med fokus på aktuelle politiske prioriteter inden for Nordisk Ministerråd. Budgetposten giver desuden mulighed for sektorerne at opnå del i prioriteringsbudgettet til at forfølge disse aktuelle politiske prioriteringer. Ved disponeringen af disse midler bør der være delfinansiering fra de relevante sektorer i form af match funding, hvilket betyder at medfinansieringen i hovedreglen bør være $50 \%$, men ses i lyset af sektorens samlede budget. Medfinansieringen fra sektorerne er med til at sikre at projektforslagene er udtryk for højt prioriterede problemstillinger som sektoren ønsker at adressere.

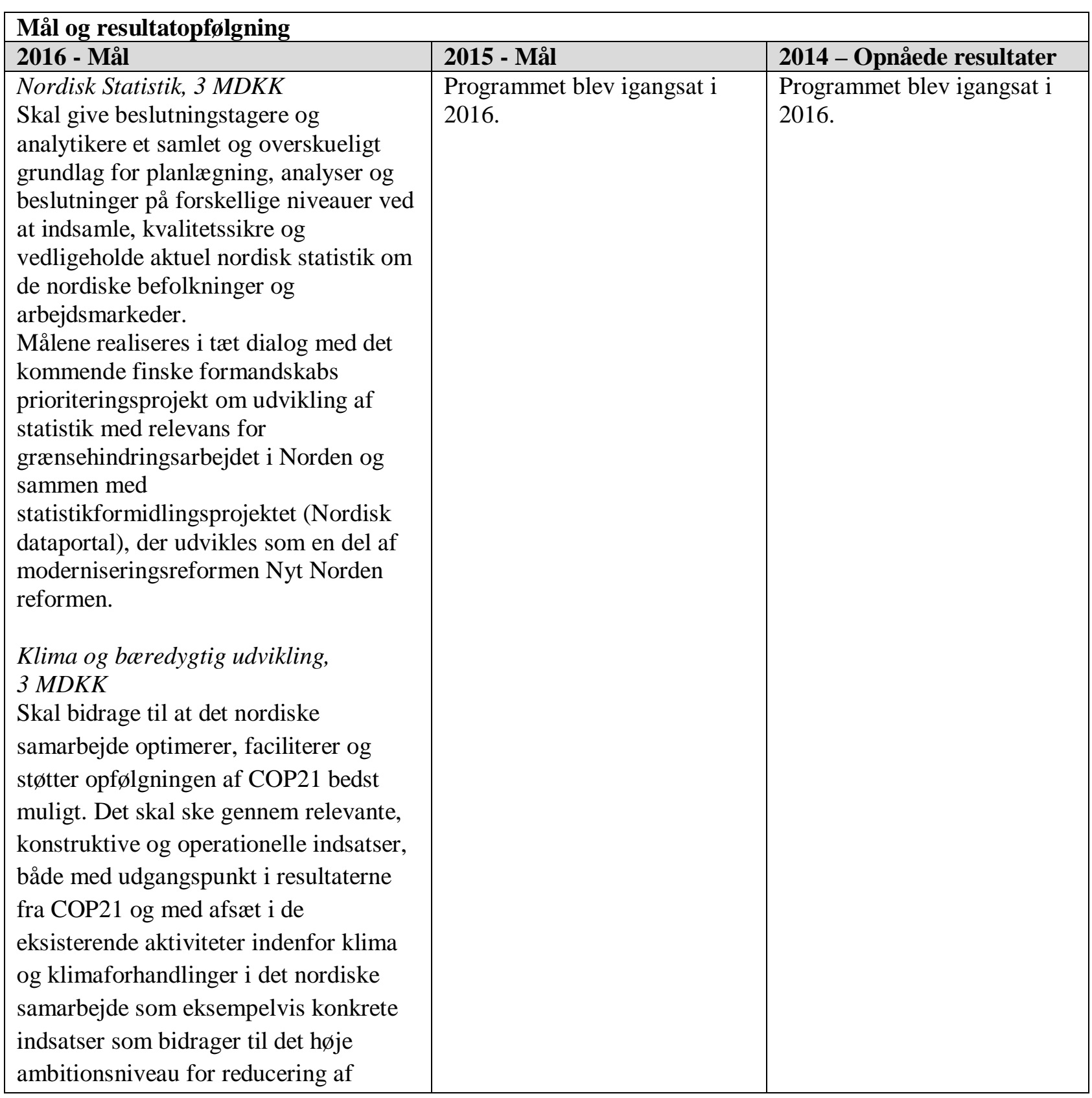


udslip i Norden og udviklingslande, klimafinansiering, Fossil Fuel Subsidy Reform, målrettet klimakommunikation, markanvendelse og bæredygtig byudvikling. Umiddelbart efter COP21 igangsættes en proces, for at konkretisere og udvikle en plan for opfølgningen af COP21 der også tager hensyn til medfinansiering fra relevante aktører.

Demokrati, inkludering og sikkerhed, $4 \mathrm{MDKK}$

Som følge af de senere års terrorbegivenheder i Norden initierer Nordisk Ministerråd i 2016 en målrettet og tværsektoriel indsats for at fremme demokratisering, inklusion og sikkerhed, og derved forebygge radikalisering og ekstremisme i Norden. Med afsæt i de nordiske værdier om ytringsfrihed, aktivt medborgerskab og social lighed, skal projektet bidrage til at dele og udbrede viden om effektive løsninger og god praksis på tværs i Norden. I 2016 vil MR-SAM medfinansiere konkrete projektforslag fra sektorerne, som kan understøtte dette formål. 
Nordisk ministerråds fællesaktiviteter og Sekretariatet

\begin{tabular}{llrrrr} 
& & Budget & Budget & \multicolumn{2}{c}{ Difference } \\
& & $\mathbf{2 0 1 6}$ & $\mathbf{2 0 1 5}$ & $+/-$ & $\mathbf{\%}$ \\
\hline Samarbejdsministrene (TDKK) & $\mathbf{1 0 6 . 5 6 3}$ & $\mathbf{1 0 6 . 5 6 3}$ & $\mathbf{0}$ & $\mathbf{0 , 0 \%}$ \\
& & & & \\
& Nordisk Ministerråds frellesaktiviteter & 29.568 & 29.003 & 565 & $1,9 \%$ \\
$1-0410$ & Föreningarna Nordens Förbund & 3.227 & 3.227 & 0 & $0,0 \%$ \\
$1-0425$ & Bidrag til Grönland & 725 & 725 & 0 & $0,0 \%$ \\
$1-0435$ & Generalsekreterarens disponeringsreserv & 412 & 412 & 0 & $0,0 \%$ \\
$1-0460$ & Holdbart Norden & 3.026 & 3.026 & 0 & $0,0 \%$ \\
$1-1011$ & Informationsaktiviteter & 5.162 & 5.162 & 0 & $0,0 \%$ \\
$1-1012$ & Norden i Fokus & 4.289 & 4.289 & 0 & $0,0 \%$ \\
$1-1030$ & Hallo Norden & 6.685 & 6.120 & 565 & $9,2 \%$ \\
$1-1036$ & Grænsehindringsråd & 4.889 & 4.889 & 0 & $0,0 \%$ \\
$1-1050$ & Tjänstemannautbyte & 1.153 & 1.153 & 0 & $0,0 \%$ \\
& Ministerrådets sekretariat (NMRS) & 76.995 & 77.560 & -565 & $-0,7 \%$ \\
$1-0180$ & Ministerrådets sekretariat (NMRS) & 76.995 & 77.560 & -565 & $-0,7 \%$ \\
& & & & & \\
\hline Opdelt på kategorier & $\mathbf{1 0 6 . 5 6 3}$ & $\mathbf{1 0 6 . 5 6 3}$ & $\mathbf{1 0 0 \%}$ & $\mathbf{1 0 0 \%}$ \\
\hline \multicolumn{2}{|c|}{ Projektmidler } & 12.889 & 12.889 & $12,1 \%$ & $12,1 \%$ \\
& Programlignende aktiviteter & 12.727 & 12.162 & $11,9 \%$ & $11,4 \%$ \\
& Institutioner & 76.995 & 77.560 & $72,3 \%$ & $72,8 \%$ \\
& Organisationsbidrag & 3.952 & 3.952 & $3,7 \%$ & $3,7 \%$
\end{tabular}

1-0410 Föreningarna Nordens Förbund

Organisationsbidrag

\begin{tabular}{|l|c|c|c|c|c|} 
Valuta & Budget 2016 & Budget 2015 & Budget 2014 & Disp./bud. 14 & Budget disp. af \\
\hline DKK & 3.227 .000 & 3.227 .000 & 3.244 .000 & $100 \%$ & FNF
\end{tabular}

Formål Foreningerne Nordens Forbund er koordineringsorgan for Norden-foreningernes aktiviteter, og Forbundets sekretariat administrerer foreningernes fælles projekter og repræsenterer foreningerne i kontakterne med Nordisk Råd og Nordisk Ministerråd.

Foreningerne Nordens Forbund vil bidrage til en aktiv samfundsdebat, påvirke det officielle nordiske samarbejdes beslutningstagere og tage initiativer, der kan medvirke til at fordybe det nordiske samarbejde indadtil og udadtil, fremme fri bevægelighed i Norden og kontakten mellem de nordiske borgere.

\begin{tabular}{|c|c|c|}
\hline \multicolumn{3}{|l|}{ Mål og resultatopfølgning } \\
\hline 2016 - Mål & 2015 - Mål & 2014 - Opnåede resultater \\
\hline $\begin{array}{l}\text { FNF arbejder for at fremme det } \\
\text { folkelige nordiske samarbejde på } \\
\text { alle niveauer. }\end{array}$ & $\begin{array}{l}\text { FNF vil fremme nordisk } \\
\text { skolesamarbejde og udvikling af } \\
\text { portalen Norden i skolen. }\end{array}$ & $\begin{array}{l}\text { Internetportalen Norden i Skolen } \\
\text { er blevet udviklet med diverse } \\
\text { nye komponenter, bl.a. med en } \\
\text { ny undervisningssektion omkring }\end{array}$ \\
\hline $\begin{array}{l}\text { FNF vil fremme nordisk } \\
\text { skolesamarbejde og forstærke } \\
\text { forståelsen af nabosprogene. } \\
\text { FNF arbejder for afskaffelse af }\end{array}$ & $\begin{array}{l}\text { Det skal også satses på grøn } \\
\text { vækst og udvikling af } \\
\text { undervisningsmateriale for } \\
\text { nordiske skoler. }\end{array}$ & $\begin{array}{l}\text { klima og miljø. } \\
\text { Udover forvaltningen af } \\
\text { Nordjobb har Forbundet under } \\
\text { året taget initiativ til projekterne }\end{array}$ \\
\hline
\end{tabular}


grænsehinder og for øget

mobilitet på det nordiske

arbejdsmarked ved diverse

initiativer.

FNF er forvaltningsorgan for Nordisk Sprogkoordination.
Desuden vil der arbejdes for at nedbryde grænsehindringer og fremme det fælles nordiske arbejdsmarked.

FNF skal også fokusere på at udvikle portalen/mødepunktet for netværket for nordiske organisationer, ONN.

FNF er forvaltningsorgan for Nordisk Sprogkoordination.

Der vil også blive lagt vægt ved dialog med Nordisk Ministerråd og Nordisk Råd.
Entreprenørskab over grenser og Nordisk Jobstart. Det førstnævnte vender sig til unge mennesker som står langt fra arbejdsmarkedet og det andet til arbejdssøgende nyuddannede.

Forbundet har under året arbejdet med at udvikle internetportalen Nordiske Netvcrk., som skal fremme samarbejde og informationsformidling.

Nordisk Sprogkoordination opfyldte i 2014 de overordnede mål, at opbygge og etablere en god koordinering af aktørerne inden for Nordisk sprogkoordination samt at igangsætte diverse initiativ inden for Sprogkoordinationens rammer.

\section{1-0425 Bidrag til Grønland}

Organisationsbidrag
\begin{tabular}{|l|c|c|c|c|c|} 
Valuta & Budget 2016 & Budget 2015 & Budget 2014 & Disp./bud. 14 & Budget disp. af \\
\hline DKK & 725.000 & 725.000 & 729.000 & $100 \%$ & Generalsekretæren
\end{tabular}

Formål Bidraget ska säkerställa västnordiska ämbetsmäns möjlighet för att delta i det nordiska samarbetet. Bidraget har tidigare gått till Färöarna, Island och Grönland. Sedan 2009 utgår bidrag enbart till Grönland.

\begin{tabular}{|l|l|l|}
\hline Mål og resultatopfølgning & 2015 - Mål & 2014 - Opnåede resultater \\
\hline $\mathbf{2 0 1 6}$ - Mål & $\begin{array}{l}\text { Att ge res-stöd till grönländska } \\
\text { ämbetsmän för deltagande i det } \\
\text { ämbetsm-stöd till grönländska } \\
\text { nordiskär deltagande i det }\end{array}$ & $\begin{array}{l}\text { Bidraget har i 2014 använts som } \\
\text { res-stöd för grönländska } \\
\text { ämbetsmäns deltagande i det } \\
\text { nordiska samarbetet. }\end{array}$ \\
\hline
\end{tabular}

$\underline{1-0435 \text { Generalsekreterarens disponeringsreserv }}$

Projektmidler
\begin{tabular}{|l|c|c|c|c|c|} 
Valuta & Budget 2016 & Budget 2015 & Budget 2014 & Disp./bud. 14 & Budget disp. af \\
\hline DKK & 412.000 & 412.000 & 414.000 & $86 \%$ & Generalsekretæren
\end{tabular}

Formål

Generalsekretærens disponeringsreserve står til generalsekretærens rådighed. Reserven gør det muligt for generalsekretæren at igangsætte projekter og undersøgelser. Reserven skal ikke benyttes til at tildele ekstra midler til institutioner, embedsmandskomitéer eller sekretariatet til formål som har været prøvet ved den ordinære budgetbehandling. 


\begin{tabular}{|l|l|l|}
\hline 2016 - Mål & 2015 - Mål & 2014 - Opnåede resultater \\
\hline $\begin{array}{l}\text { At sætte fokus på særlige } \\
\text { problemstillinger og dække } \\
\text { uforudsete udgifter for afsluttede } \\
\text { projekter samt igangsætte nye } \\
\text { projekter og undersøgelser. }\end{array}$ & $\begin{array}{l}\text { At sætte fokus på særlige } \\
\text { problemstillinger og dække } \\
\text { uforudsete udgifter for afsluttede } \\
\text { projekter samt igangsætte nye } \\
\text { projekter og undersøgelser. }\end{array}$ & $\begin{array}{l}\text { I 2014 er midlerne først og } \\
\text { fremmest brugt til administrative } \\
\text { omkostninger i forbindelse med } \\
\text { konsulentbistand til udredningen } \\
\text { af reglerne for statsstøtte og } \\
\text { moderniseringsarbejdet. Dertil } \\
\text { kommer udgifter til formidlings- } \\
\end{array}$ \\
& $\begin{array}{l}\text { og kommunikationsvirksomhed } \\
\text { der har været fokuseret opå en } \\
\text { film om nordisk samarbejde i } \\
\text { forbindelse med Nordisk Råds } \\
\text { session 2014. }\end{array}$ \\
\hline
\end{tabular}

$\underline{\text { 1-0460 Hållbart Norden }}$

\begin{tabular}{|l|c|c|c|c|c|} 
Projektmidler & & Budget 2015 & Budget 2014 & Disp./bud. 14 & Budget disp. af \\
\hline Valuta & Budget 2016 & BudS & 3.026.000 & 3.042 .000 & NSK/MR-SAM
\end{tabular}

Formål De nordiska samarbetsministrarna har beslutat att allt arbete som görs inom ramen för Nordiska ministerrådet ska ha ett integrerat hållbarhetsperspektiv. Budgetposten Hållbart Norden ska användas till aktiviteter som bidrar till att nå denna målsättning och för att sätta igång pilotprojekt som stödjer implementeringen av den Nordiska strategin för hållbar utveckling - Ett gott liv i ett hållbart Norden.

Anslaget ska också användas för att förstärka kommunikationsinsatser kring NMR:s hållbarhetsarbete, inklusive uppföljningen av de nordiska indikatorerna för hållbar utveckling. Aktiviteterna ska riktas både till Norden, dess närområden och internationellt. NMR ska även följa upp och implementera Rio+20 konferensens resultat, härunder arbetet med globala hållbarhetsmålsättningar.

Målen för 2016 är i enlighet med strategin för hållbar utveckling som godkänts av samarbetsministrarna.

\begin{tabular}{|c|c|c|}
\hline \multicolumn{3}{|l|}{ Mål og resultatopfølgning } \\
\hline 2016 - Mål & 2015 - Mål & 2014 - Opnåede resultater \\
\hline $\begin{array}{l}\text { Stödja implementeringen av } \\
\text { strategin generellt och i } \\
\text { förhållande till ministerrådets } \\
\text { facksektorer. } \\
\text { Vidareutveckling av } \\
\text { hållbarhetsportalen GRO för att } \\
\text { garantera att verktyget är relevant } \\
\text { och användbart. } \\
\text { Engagera ministerrådets } \\
\text { facksektorer i arbetet med hållbar } \\
\text { utveckling. Främja } \\
\text { implementeringen av strategin } \\
\text { genom att initiera tvärsektoriell }\end{array}$ & $\begin{array}{l}\text { Främja implementeringen av } \\
\text { strategin genom att initiera } \\
\text { tvärsektoriell projektverksamhet } \\
\text { inom följande prioriteringar: } \\
\text { Hållbar konsumtion och } \\
\text { produktion: Norden ersätter en } \\
\text { konsumtionskultur med en } \\
\text { hållbar återanvändningskultur } \\
\text { baserad på miljöanpassad } \\
\text { produktion och konsumtion. } \\
\text { Uppföljning och implementering } \\
\text { av Rio+20 konferensens resultat, }\end{array}$ & $\begin{array}{l}\text { Implementeringen av den } \\
\text { Nordiska strategin för hållbar } \\
\text { utveckling - Ett gott liv i ett } \\
\text { hållbart Norden inleddes. För att } \\
\text { stärka sektorernas arbete med } \\
\text { hållbarhetsintegrering, togs i } \\
2014 \text { fram en elektronisk } \\
\text { hållbarhetsportal GRO, på } \\
\text { adressen www.gro.norden.org. } \\
\text { Verktyget innehåller även en } \\
\text { kommunikationsmodul, med } \\
\text { syfte att förstärka } \\
\text { kommunikationen kring } \\
\text { ministerrådets aktiviteter inom }\end{array}$ \\
\hline
\end{tabular}


projektverksamhet.

Delta aktivt i det internationella arbetet om hållbar utveckling, speciellt inom EU, OECD och FN.

Följa upp FN:s konferens för hållbar utveckling Rio+20, härunder arbetet med de globala hållbarhetsmålsättningarna, Sustainable Development Goals.

Kommunikationsinsatser om NMR:s hållbarhetsarbete ska förstärkas. Bl. a genom en uppdaterad rapport om nordiska indikatorer för hållbar utveckling i 2016. med fokus på folklig förankring av den globala

hållbarhetsdagordningen, särskilt beträffande förhandlingar om globala hållbarhetsmål.

Kommunikationsinsatser om NMR:s hållbarhetsarbete ska förstärkas. Bl. a genom rapport om nordiska indikatorer för hållbar utveckling 2015.

Genomförandet av verktygsprojektet ska följas upp och ministerrådets facksektorer ska stödjas i arbetet med hållbar utveckling.

\section{Redogörelse om} implementeringen av strategin ska läggas fram vid Nordiska rådets session 2015 . hållbar utveckling.

För att stärka implementeringen av strategin genomfördes en utlysning för tvärsektoriella projekt. Sammanlagt 2,7 MDKK delades ut till tre projekt:

- Funktionshindersperspektiv, kön och mångfald

- KONNECT: Förmedling av forskningsresultat om hållbarhetsutmaningar via konst och kultur

- Ekosystemtjänster: Genetiska resurser till de vilda

kulturväxterna

De nordiska indikatorenar för hållbar utveckling har uppdaterats kontinuerligt på ministerrådets hemsida. NMR utgav också i en tryckt version av Nordic Sustainable Development Indicators 2014.

\section{1-1011 Informationsaktiviteter}

Projektmidler
\begin{tabular}{|l|c|c|c|c|c|} 
Valuta & Budget 2016 & Budget 2015 & Budget 2014 & Disp./bud. 14 & Budget disp. af \\
\hline DKK & 5.162 .000 & 5.162 .000 & 5.086 .000 & $100 \%$ & Generalsekretæren
\end{tabular}

Formål Syftet med kommunikationsaktiviteterna, som är en del av Kommunikationsavdelningens verksamhet, är att stödja Nordiska ministerrådets politiska mål. De ska öka dialogen och förstärka relationerna med det omgivande samhället samt skapa ett större engagemang för nordisk politik hos intressenter nationellt och internationellt.

\begin{tabular}{|l|l|l|}
\hline Mål og resultatopfølgning & 2015 - Mål & 2014 - Opnåede resultater \\
\hline 2016 - Mål & $\begin{array}{l}\text { Implementera och aktivera den } \\
\text { ntärka Nordens konkurrenskraft } \\
\text { och internationella inflytande. }\end{array}$ & $\begin{array}{l}\text { Ny kommunikationsstrategi i } \\
\text { linje med visionen togs fram för } \\
\text { beslut i början av 2015. }\end{array}$ \\
$\begin{array}{l}\text { Med samma syfte och mål som } \\
\text { ovan lägga vikt vid uppföljning } \\
\text { samt fortsatt arbete med att ta } \\
\text { fram stödjande verktyg. }\end{array}$ & $\begin{array}{l}\text { Norden, det senare i första hand i } \\
\text { samarbete med ordförandelandet } \\
\text { Danmark. }\end{array}$ & $\begin{array}{l}\text { En strategi för internationell } \\
\text { profilering och positionering av } \\
\text { Norden togs fram och beslutades. }\end{array}$ \\
$\begin{array}{l}\text { Implementera och aktivera } \\
\text { strategin för profilering av } \\
\text { Norden i Norden. }\end{array}$ & $\begin{array}{l}\text { I linje med ovan nämnda strategi } \\
\text { öka genomslagskraften för det } \\
\text { nordiska samarbetet inom } \\
\text { Norden. }\end{array}$ & $\begin{array}{l}\text { Den fælles nordiske publikations- } \\
\text { platform, NordPub, lanceredes } \\
\text { den 26. marts 2014 } \\
\text { (www.norden.org/nordpub). }\end{array}$ \\
Fortsat udvidelse og udvikling af & $\begin{array}{l}\text { Fortsatt implementering av } \\
\text { kommunikationsstrategin samt ett }\end{array}$ & Till raden av arenor för synlighet \\
\hline
\end{tabular}




\begin{tabular}{|c|c|c|}
\hline $\begin{array}{l}\text { Implem } \\
\text { Norden } \\
\text { datapor } \\
\text { udnytte } \\
\text { statistik } \\
\text { af et sta } \\
\text { visualis } \\
\text { datapor }\end{array}$ & $\begin{array}{l}\text { moderniserat arbetssätt för } \\
\text { kommunikation i hela } \\
\text { organisationen. } \\
\text { I linje med } \\
\text { kommunikationsstrategin stärka } \\
\text { ledningskommunikationen i } \\
\text { organisationen. } \\
\text { Skapa omedelbar och löpande } \\
\text { tillgång till färsk nordisk statistik } \\
\text { genom digitalisering. } \\
\text { Säkra servicegraden vad gäller } \\
\text { fakta om gränshinder för } \\
\text { medborgarna i hela Norden. } \\
\text { Genomföra nästa steg för Open } \\
\text { access. }\end{array}$ & $\begin{array}{l}\text { och genomslagskraft av den } \\
\text { nordiska politiken tillades Suomi } \\
\text { Arena i Finland. } \\
\text { Utvecklingen och användandet av } \\
\text { digitala kanaler för att öka } \\
\text { tillgängligheten till det nordiska } \\
\text { samarbetet intensifierades. På så } \\
\text { sätt ökades synligheten av den } \\
\text { politiska debatten, den kunskap } \\
\text { som genereras samt den konkreta } \\
\text { nyttan som man som medborgare } \\
\text { kan ha av samarbetet. } \\
\text { Beslut om att som en del av Nytt } \\
\text { Norden genomföra en översyn av } \\
\text { den totala organisationens } \\
\text { kommunikationsresurs samt av } \\
\text { möjligheterna att bättre } \\
\text { tillgängliggöra nordisk statistik. } \\
\text { Forundersøgelser for } \\
\text { igangsættelse af Nyt Norden } \\
\text { projekt om nordisk statistik } \\
\text { igangsattes i efteråret } 2014 \text { under } \\
\text { navnet Nordisk dataportal. } \\
\text { Med hjälp av } \\
\text { rekryteringsåtgärder samt } \\
\text { kompetensutveckling säkrades } \\
\text { tillgängligheten och kvalitén av } \\
\text { tolkning och översättning på } \\
\text { Nordens språk, i synnerhet } \\
\text { isländska. }\end{array}$ \\
\hline
\end{tabular}

\section{$\underline{1-1012 \text { Norden i Fokus }}$}

Projektmidler

\begin{tabular}{|l|c|c|c|c|c|} 
Valuta & Budget 2016 & Budget 2015 & Budget 2014 & Disp./bud. 14 & Budget disp. af \\
\hline DKK & 4.289 .000 & 4.289 .000 & 4.423 .000 & $97 \%$ & Generalsekretæren
\end{tabular}

Formål Norden i Fokus har til formål at synliggøre Nordisk Ministerråds vision om et grænseløst, innovativt, udadvendt og synligt Norden gennem arrangementer, der indgår i og relaterer til de nationale, politiske debatter rundt om i Norden

Forvaltnings- Danmark - Nordisk Ministerråd (kommunikationsafdelingen)

organ

Finland - Kulturkontakt Nord

Island - Nordens Hus 
Norge - Nordic Innovation

Sverige - Nordens Velfærdscenter

Mål og resultatopfølgning

2016 - Mål

At gennemføre 60 seminarer, debatter og events som sætter Norden på dagsordenen i relation til de nationale, politiske debatter eksempelvis på de politiske festivaler i Allinge, Almedalen, Arendal, Suomi Areena og den nye politiske festival i Island i Vatnsmýrin.

2015 - Mål

At gennemføre 60 debatter og events som sætter Norden på dagsordenen i relation til de nationale, politiske debatter primært på de politiske festivaler i Allinge, Almedalen, Arendal og Suomi Areena.

\section{4 - Opnåede resultater}

70 debatter og events i

samarbejde med interne og eksterne partnere blev gennemført. Heraf blev hovedparten afviklet på de politiske festivaler i Allinge, Almedalen, Arendal og Suomi Areena.

Arrangementerne planlægges og afvikles ideelt i samarbejde med interne samarbejdspartnere (Udenrigsministerier, Nordisk Råds delegationer, institutioner mv.) og eksterne samarbejdspartnere som organisationer, NGO'er, medier osv.

\section{$\underline{1-1030 \text { Hallo Norden }}$}

Programlignende aktiviteter

\begin{tabular}{|l|c|c|c|c|c|} 
Valuta & Budget 2016 & Budget 2015 & Budget 2014 & Disp./bud. 14 & Budget disp. af \\
\hline DKK & 6.685 .000 & 6.120 .000 & 5.823 .000 & $100 \%$ & Generalsekretæren
\end{tabular}

Formål

Forvaltnings- $\quad$ Danmark - Foreningen Norden organ

Hallo Nordens formål er at understøtte privatpersoners mobilitet i Norden. Dette gøres ved at informere og vejlede borgere, der har brug for information når de skal flytte, arbejde eller studere i et andet nordisk land. Hallo Nordens informationer findes på www.norden.org og personlige service yder pr. mail, telefon og via netsidernes spørgeformular. Hallo Norden gør et enklere at være borger i Norden. I 2016 er budgettet for denne budgetpost øget med 565.000 DKK for at sikre en mere rimelig fordeling af fællesudgifterne til hjemmesiden www.norden.org mellem Hallo Norden og den øvrige virksomhed. Midlerne er taget fra budgetpost 1-0180 Ministerrådets sekretariat.

Finland - Foreningen Norden

Island - Foreningen Norden

Norge - Foreningen Norden

Sverige - Foreningen Norden

Åland - Foreningen Norden

Færøerne - Nordisk Atlantsamarbejde (NORA)

Grønland - Nordens Institut i Grønland (NAPA) (fra 2015)

\begin{tabular}{|c|c|c|}
\hline \multicolumn{3}{|l|}{ Mål og resultatopfølgning } \\
\hline 2016 - Mål & 2015 - Mål & 2014 - Opnåede resultater \\
\hline $\begin{array}{l}\text { At øge trafikken på } \\
\text { Norden.org/Hallo Norden med } \\
\text { min. } 100.000 \text { besøg }\end{array}$ & $\begin{array}{l}\text { At øge trafikken på } \\
\text { Norden.org/Hallo Norden med } \\
200.000 \text { besøg i forhold til } 2014 .\end{array}$ & $\begin{array}{l}900.000 \text { besøg på Hallo Nordens } \\
\text { netsted. Det er en stigning på ca. } \\
20.000 \text { besøg i forhold til } 2013 . \\
\text { Grunden til at stigningen ikke }\end{array}$ \\
\hline $\begin{array}{l}\text { At indsamle og registrere } \\
\text { samtlige grænsehindringer i }\end{array}$ & $\begin{array}{l}\text { At indsamle og registrere samtlige } \\
\text { grænsehindringer i Nordisk }\end{array}$ & $\begin{array}{l}\text { har været så stor som forventet } \\
\text { skyldes budgetnedskæringer som }\end{array}$ \\
\hline
\end{tabular}




\begin{tabular}{|c|c|c|}
\hline $\begin{array}{l}\text { Nordisk Ministerråds } \\
\text { grænsehindringsdatabase samt } \\
\text { bidrage til en nordisk portal for } \\
\text { erhvervsivet med fokus på } \\
\text { grænsehindringsspørgsmål. } \\
\text { At afholde min. } 20 \text { seminarer og } \\
\text { møder med myndigheder for at } \\
\text { informere om vigtige aspekter af } \\
\text { det at arbejde, bo og studere i } \\
\text { Norden. } \\
\text { At målrette Hallo Nordens } \\
\text { services til udvalgte målgrupper: } \\
\text { Studievejledere og jobcentre. }\end{array}$ & $\begin{array}{l}\text { Ministerråds } \\
\text { grænsehindringsdatabase. } \\
\text { At besvare spørgsmål fra nordiske } \\
\text { borgere, der ønsker at arbejde, bo } \\
\text { eller studere i et andet nordisk } \\
\text { land. } \\
\text { At informere myndigheder, } \\
\text { sagsbehandlere, organisationer og } \\
\text { organisationer om vigtige aspekter } \\
\text { af det at arbejde, bo og studere i } \\
\text { Norden, } \\
\text { At implementere ny infomations- } \\
\text { struktur på Hallo Nordens net- } \\
\text { sider. }\end{array}$ & 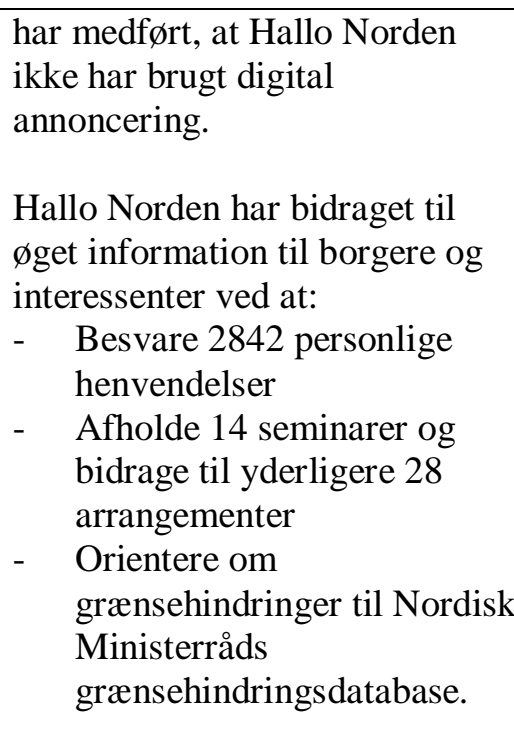 \\
\hline
\end{tabular}

Målene for Hallo Norden søges realiseret hovedsageligt via udvikling af Hallo Nordens sider på Norden.org, digital annoncering via Google samt direkte digital spørgeservice til brugere.

\section{1-1036 Grænsehindringsråd}

\section{Programlignende aktiviteter}

\begin{tabular}{|l|c|c|c|c|c|} 
Valuta & Budget 2016 & Budget 2015 & Budget 2014 & Disp./bud. 14 & Budget disp. af \\
\hline DKK & 4.889 .000 & 4.889 .000 & 5.076 .000 & $93 \%$ & Generalsekretæren
\end{tabular}

Formål Bevillingen har til formål at sikre finansieringen af Grænsehindringsrådets aktiviteter samt øvrige aktiviteter relateret til grænsehindringsarbejdet mellem de nordiske lande. Overordnet set skal bevillingen lette menneskers og virksomheders grænseoverskridende aktiviteter i Norden.

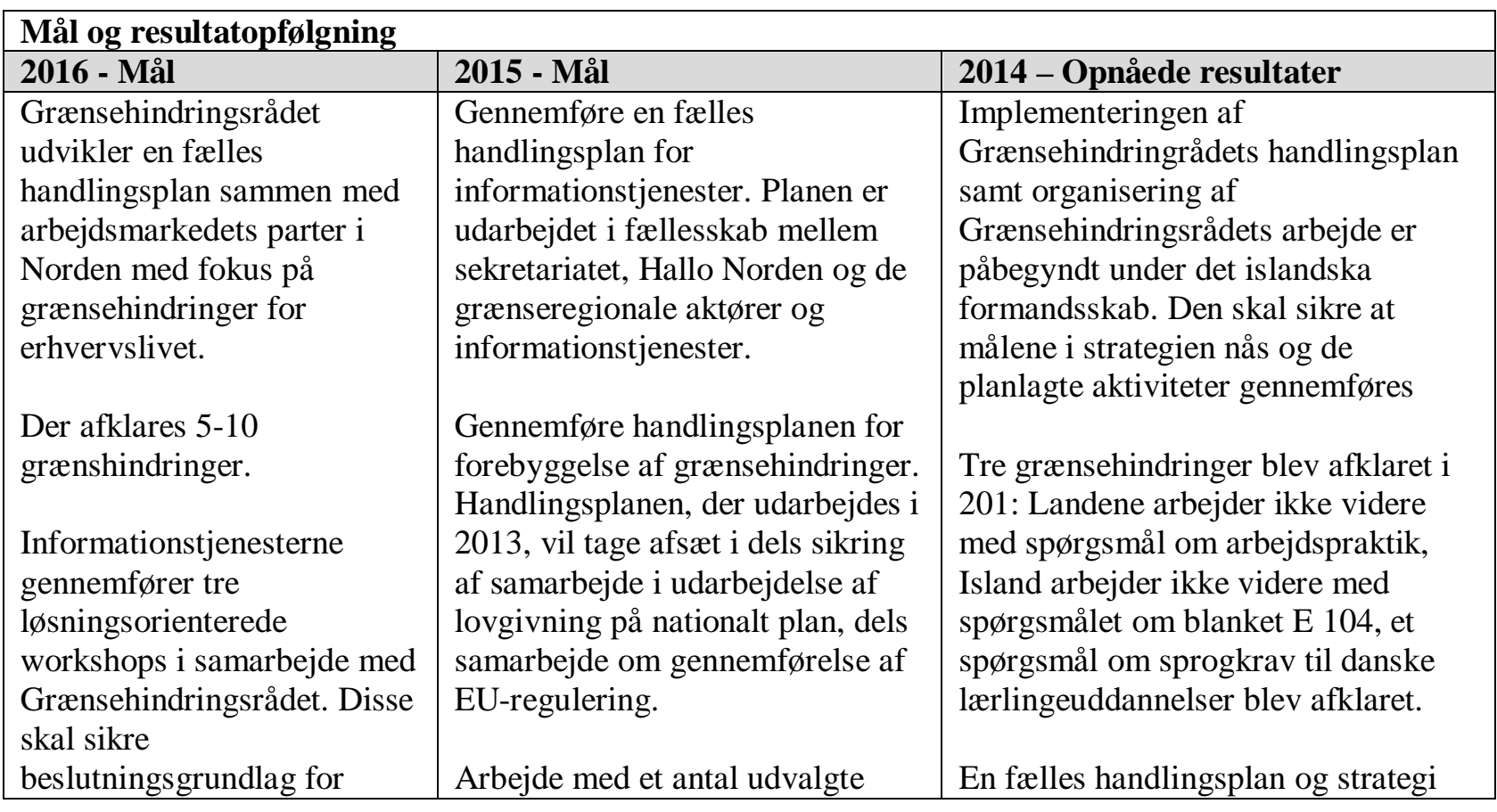




\begin{tabular}{|c|c|c|}
\hline $\begin{array}{l}\text { arbejde med løsninger. } \\
\text { En nordisk portal for } \\
\text { erhvervslivet startes op i } \\
\text { samarbejde med de } \\
\text { grænseregionale } \\
\text { informationstjenester. } \\
\text { Handlingsplanen for } \\
\text { forebyggelse af } \\
\text { grænsehindringer udfoldes. } \\
\text { De ni konkrete initiativer } \\
\text { undersøges og sættes i drift } \\
\text { hvis muligt }\end{array}$ & $\begin{array}{l}\text { grænsehindringer. Hvert medlem } \\
\text { er ansvarlig for hindringer, der } \\
\text { drives med støtte fra sekretariatet. } \\
\text { Det er et mål at der udarbejdes et } \\
\text { velfungerende samarbejde med } \\
\text { relevante ministerråd og } \\
\text { embedsmandskomiteer. }\end{array}$ & $\begin{array}{l}\text { for Hallo Norden og de } \\
\text { grænseregionale aktører er udviklet } \\
\text { og gennemført. } \\
\text { Den indeholder aftaler om } \\
\text { samarbejde om } \\
\text { grænsehindringsdatabasen, } \\
\text { samarbejde internt mellem } \\
\text { organisationer og samarbejde mellem } \\
\text { sekretariatet og organisationerne } \\
\text { En strategi og handlingsplan for det } \\
\text { forebyggende arbejde mod } \\
\text { grænsehindringer er påbegyndt og vil } \\
\text { blive gennemført i 2015-2016. Den } \\
\text { indeholder ni konkrete aktiviteter, der } \\
\text { skal sikre samarbejde mellem landene } \\
\text { på lovgivningsområdet } \\
\text { Udredning af samarbejde mellem de } \\
\text { nordiske ombudsmandsinstitutioner } \\
\text { vil blive gennemført i 2015. Den skal } \\
\text { sikre et tættere samarbejde mellem } \\
\text { ombudsmandsinstitutionerne og } \\
\text { undersøge om dekan indgå i } \\
\text { grænsehindrinsarbejdet. }\end{array}$ \\
\hline
\end{tabular}

\section{1-1050 Tjänstemannautbyte}

Programlignende aktiviteter

\begin{tabular}{|l|c|c|c|c|c|} 
Valuta & Budget 2016 & Budget 2015 & Budget 2014 & Disp./bud. 14 & Budget disp. af \\
\hline DKK & 1.153 .000 & 1.153 .000 & 1.321 .000 & $65 \%$ & Kontaktgruppen
\end{tabular}

Formål Syftet med stipendieordningen Nordiskt tjänstemannautbyte är att stärka möjligheten för statsanställda i Norden att få ökad kunskap om förvaltningsstrukturer och arbetsmetoder i de andra nordiska länderna och Färöarna, Grönland och Åland. Nordiskt tjänstemannautbyte bidrar även till kompetensutveckling för den enskilde och för sändande och mottagande myndighet genom kunskaps- och erfarenhetsutbyte inom olika sektorer i hela Norden.

\begin{tabular}{|l|l|l|}
\hline Mål og resultatopfølgning & 2015 - Mål & 2014 - Opnåede resultater \\
\hline 2016 - Mål & Målet är att stärka de fackliga & Målet från 2013 att öka antalet \\
Målet är att stärka de fackliga & stipendiater från i synnerhet \\
nätverken mellan statliga & nätverken mellan statliga & Sverige och Norge är uppfyllt. \\
myänstemän och statliga & tjänstemän och statliga & Antalet stipendiater från Sverige \\
länderna. & myndigheter i de nordiska & har ökat från 1 till 8 stycken och \\
& län norn Norge från 4 till 12 stycken. \\
& & Ökningarna beror på riktade \\
& & insatser mot myndigheternas HR \\
& & avdelningar genom seminarier \\
& & och liknande, också inom andra \\
& & nordiska fora. \\
\hline
\end{tabular}


1-0180 Ministerrådets sekretariat (NMRS)

Institution
\begin{tabular}{|l|c|c|c|c|c|} 
Valuta & Budget 2016 & Budget 2015 & Budget 2014 & NMR fin. 14 & Budget disp. af \\
\hline DKK & 76.995 .000 & 77.560 .000 & 78.204 .000 & $0 \%$ & Institutionen
\end{tabular}

Formål Nordisk Ministerråds sekretariat er et politisk sekretariat for Nordisk Ministerråd. Sekretariatet skal effektivt løse de opgaver som Nordisk Ministerråd giver sekretariatet. Sekretariatet bidrager på opdrag af de nordiske landes og Færøerne, Grønland og Ålands regeringer samt på generalsekretærens initiativ til at udvikle og forstærke det nordiske samarbejde og fremme de nordiske interesser i verden.

Nordisk Ministerråds sekretariats mission er følgende:

- Initiere, iværksætte og følge op på politiske beslutninger

- Udvikle viden som skal danne grundlag for fælles løsninger

- Etablere netværk med henblik på udveksling af nye erfaringer og ideer

\begin{tabular}{|c|c|c|}
\hline \multicolumn{3}{|l|}{ Mål og resultatopfølgning } \\
\hline 2016 - Mål & 2015 - Mål & 2014 - Opnåede resultater \\
\hline $\begin{array}{l}\text { Sekretariatet skal fortsat bidrage } \\
\text { til at udvikle, modernisere og } \\
\text { effektivisere nordisk } \\
\text { samarbejde gennem } \\
\text { implementering af } \\
\text { moderniseringsrapporten Nyt } \\
\text { Norden. } \\
\text { Sekretariatet skal aktivt } \\
\text { understøtte arbejdet med } \\
\text { strategien for profilering og } \\
\text { positionering af Nordisk } \\
\text { Ministerråd. } \\
\text { Sekretariatet vil arbejde for at } \\
\text { sikre at de nye retningslinjer for } \\
\text { projekter under } \\
\text { prioriteringsbudgettet } \\
\text { implementeres på bedst mulige } \\
\text { måde. } \\
\text { Desuden forbereder } \\
\text { sekretariatet behandlingen af } \\
\text { sager i ministerrådene, } \\
\text { samarbejdskomiteen og } \\
\text { embedsmandskomiteen og } \\
\text { implementerer beslutningerne. }\end{array}$ & $\begin{array}{l}\text { Sekretariatet skal fortsat bidrage } \\
\text { til at udvikle, modernisere og } \\
\text { effektivisere nordisk samarbejde } \\
\text { gennem implementering af } \\
\text { moderniseringsrapporten Nyt } \\
\text { Norden. } \\
\text { Sekretariatet skal også bidrage } \\
\text { til at udvikle det nordiske } \\
\text { samarbejde ved at tage nye } \\
\text { samarbejdsinitiativer og fremme } \\
\text { de nordiske interesser i verden. } \\
\text { Desuden forbereder sekretariatet } \\
\text { behandlingen af sager i } \\
\text { ministerrådene, } \\
\text { samarbejdskomiteen og } \\
\text { embedsmandskomiteen og } \\
\text { implementerer beslutningerne. }\end{array}$ & $\begin{array}{l}\text { I } 2014 \text { vedtog MR-SAM } \\
\text { implementeringsplanen for } \\
\text { generalsekretærens } \\
\text { moderniseringsopdrag som } \\
\text { beskrevet i moderniseringsrapporten } \\
\text { Nyt Norden. Det løbende } \\
\text { moderniseringsarbejde koordineres } \\
\text { og varetages af sekretariatet. } \\
\text { MR-SAM vedtog i } 2014 \text { en strategi } \\
\text { og implementeringsplan for } \\
\text { profilering og positionering af } \\
\text { Norden på baggrund af } \\
\text { sekretariatets forslag. Sekretariatet } \\
\text { vil løbende bidrage til at understøtte } \\
\text { det videre arbejde. } \\
\text { Med henblik på at forstærke } \\
\text { sekretariatets fokus på sikker drift } \\
\text { vedrørende forvaltningen af } \\
\text { nordiske midler og i tråd med Nyt } \\
\text { Norden har generalsekretæren } \\
\text { oprettet en controllerfunktion med } \\
\text { opstart efterår } 2014 \text {. } \\
\text { Sekretariatet har i } 2014 \text { startet } \\
\text { arbejdet med employer branding for } \\
\text { at sikre en bredere rekruttering, } \\
\text { herunder øge antallet af } \\
\text { kvalificerede ansøgninger blandt } \\
\text { alle de nordiske lande, dels gøre } \\
\text { sekretariatet mere kendt og attraktiv } \\
\text { som arbejdsplads. }\end{array}$ \\
\hline
\end{tabular}




\section{Internationalt samarbejde}

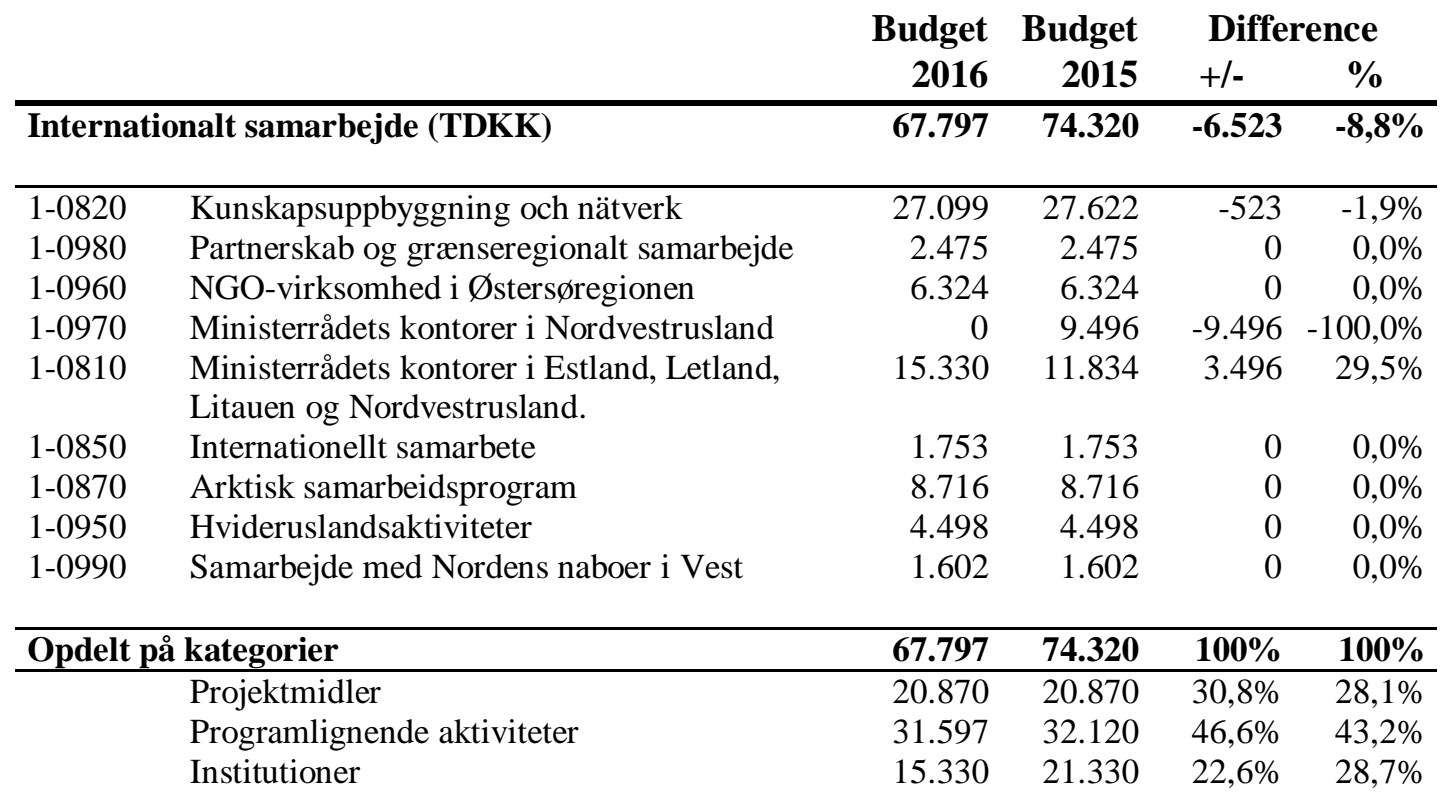

Som følge av at russiske myndigheter listet Nordisk Ministerråds kontor i Nord-Vestrussland som "utenlandsk agent", besluttet samarbeidsministrene i mars 2015 å avvikle virksomheten ved kontoret på ubestemt tid.

Kontorets kapasitet reduseres i løpet av 2015 til et minimum som skal til for å ivareta forpliktelsene i gjeldende avtaleforhold med Russland. Prosjektporteføljen gjennomgås med sikte på å avklare hva slags aktivitet som kan og bør videreføres i annen regi enn Russlandskontoret og hva som må avvikles helt. I den situasjonen som har utviklet seg i regionen, søkes det å få til en dreining av Ministerrådets innsats bl.a. mot Baltikum med utgangspunkt i kontorene i Tallin, Riga og Vilnius. De regionale bevilgningene til "kunnskap og nettverk", NGO-programmet og "partnerskap og grenseregionalt samarbeid" vil bli vurdert i denne sammenheng.

Fremtidig aktivitet i forhold til nordvestrussland vurderes i samarbeid med en arbeidsgruppe av eksperter fra de nordiske land. Som følge av de inntrufne endringer er bevilgningen til informationskontoret i Nordvestrussland slått sammen med bevilgningen til de øvrige kontorene. Denne samlede bevilgningen er i budsjettforslaget for 2016 redusert med 6 millioner kroner som følge av avvikling av virksomhet i Russland.

1-0820 Kunskapsuppbyggning och nätverk

Programlignende aktiviteter
\begin{tabular}{|l|c|c|c|c|c|} 
Valuta & Budget 2016 & Budget 2015 & Budget 2014 & Disp./bud. 14 & Budget disp. af \\
\hline DKK & 27.099 .000 & 27.622 .000 & 27.962 .000 & $96 \%$ & NSK/MR-SAM
\end{tabular}

Formål $\quad$ Budgetposten har til hovedformål at skabe netværk mellem de nordiske lande og i nærområdet; fortrinsvis de baltiske lande og Nordvestrusland, for der igennem at skabe kontakt på alle niveauer i samfundene og bidrage til stabilitet i regionen.

Nedennævnte mål for 2016 er i overensstemmelse, dels med de af MR-SAM besluttede retningslinjer for samarbejdet med Nordvestrusland henholdsvis med Estland, Letland og Litauen fra 2014, dels med senere MR-SAM beslutninger. 
Forvaltningsorgan
Forvaltningsorganer er primært NMRs kontorer i Østersøregionen og nordiske institutioner, m.fl. Pga. afviklingen af virksomheden på kontorerne i Nordvestrusland indgår de ikke i det videre arbejde.

\begin{tabular}{|c|c|c|}
\hline \multicolumn{3}{|l|}{ Mål og resultatopfølgning } \\
\hline 2016 - Mål & 2015 - Mål & 2014- Opnåede resultater \\
\hline $\begin{array}{l}\text { At videreudvikle de nordisk- } \\
\text { baltiske mobilitetsprogrammer, } \\
\text { som finansieres af budgetposten. } \\
\text { Med udgangspunkt i det } \\
\text { eksisterende program for } \\
\text { Kundskabsopbygning og } \\
\text { Netværk at udvikle nye } \\
\text { programmer og indsatser i } \\
\text { forhold til Nordvestrusland, der } \\
\text { kan etableres og forvaltes uden } \\
\text { hjælp fra NMR kontoret i Skt. } \\
\text { Petersborg. } \\
\text { At opbygge netværk på tværs af } \\
\text { Østersøen og derigennem udvikle } \\
\text { det nordisk-russiske, det nordisk- } \\
\text { baltiske og det nordisk-baltisk- } \\
\text { russiske samarbejde. } \\
\text { De konkrete aktiviteter vil blive } \\
\text { besluttet løbende inden for de } \\
\text { overordnede rammer. }\end{array}$ & $\begin{array}{l}\text { At videreudvikle programmet for } \\
\text { Kundskabsopbygning og netværk } \\
\text { samt de Nordisk-baltiske } \\
\text { mobilitetsprogrammer, som } \\
\text { finansieres af budgetposten. } \\
\text { At opbygge netværk på tværs af } \\
\text { Østersøen og derigennem udvikle } \\
\text { det nordisk-russiske, det nordisk- } \\
\text { baltiske og det nordisk-baltisk- } \\
\text { russiske samarbejde. } \\
\text { I samarbejdet med Rusland vil } \\
\text { der være særligt fokus på støtte til } \\
\text { demokratiudvikling og } \\
\text { civilsamfund samt på } \\
\text { grænseoverskridende } \\
\text { problemstillinger såsom } \\
\text { menneskehandel, miljøproblemer } \\
\text { og økonomisk kriminalitet. } \\
\text { Samarbejdet med de baltiske } \\
\text { lande har fokus på de fælles } \\
\text { mobilitetsprogrammer indenfor } \\
\text { offentlig administration } \\
\text { henholdsvis kultur. }\end{array}$ & $\begin{array}{l}\text { Det nordisk-russiske og nordisk- } \\
\text { baltisk-russiske samarbejde blev } \\
\text { videreudviklet med udgangspunkt } \\
\text { i de nye retningslinjer for } \\
\text { samarbejdet fra } 2014 . \\
\text { Opbygning af netværk gennem } \\
\text { udvikling og gennemførelse af } \\
\text { nordisk-russiske projekter er } \\
\text { foretaget. } \\
\text { Der har eksempelvis været } \\
\text { afholdt konferencer og seminarer } \\
\text { om energieffektivitet. } \\
\text { NGO-samarbejde er blevet } \\
\text { styrket gennem etablerede } \\
\text { netværker støttet af NMR, } \\
\text { Endvidere har der været } \\
\text { aktiviteter om } \\
\text { demokratiudvikling og } \\
\text { parlamentarikersamarbejde. }\end{array}$ \\
\hline
\end{tabular}

Parallelt med at den operationelle virksomhed for Ministerrådets kontorer i Nordvestrusland afvikles, vil Nordisk Ministerråd vurdere og beslutte om gennemførelse af Kundskabsopbygning og Netværk på områder af fælles nytte i Rusland og øvrige lande i nærområdet.

1-0980 Partnerskap och gränsregionalt samarbete

Projektmidler

\begin{tabular}{|l|c|c|c|c|c|} 
Valuta & Budget 2016 & Budget 2015 & Budget 2014 & Disp./bud. 14 & Budget disp. af \\
\hline DKK & 2.475 .000 & 2.475 .000 & 2.438 .000 & $90 \%$ & NSK/MR-SAM
\end{tabular}

Formål

Formålet med Nordisk Ministerråds internationale samarbejde med Nordens nabolande er at bidrage til skabelse af en stabil og økonomisk stærk region. Dette gælder først og fremmest Østersøregionen og Barentsregionen, men også Arktis og nabolandene mod syd og vest og

I overensstemmelse med MR-SAM beslutninger og strategier er de nedenfor nævnte mål fastlagt for 2016.

Forvaltnings- $\quad$ Forvaltningsorganer er primært nordiske institutioner og NMRs kontorer i organ Østersøregionen. 


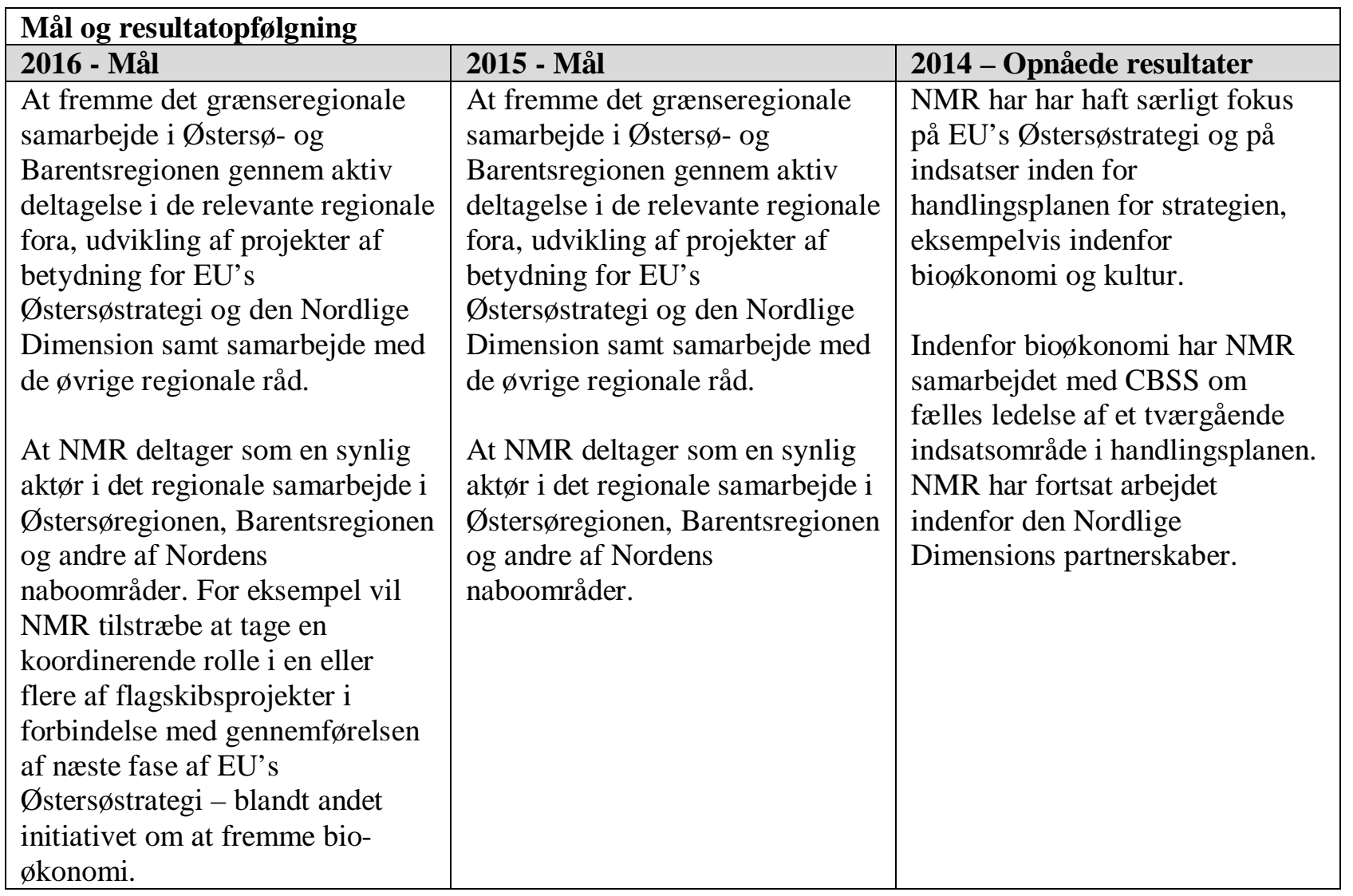

1-0960 NGO-verksamhet i Östersjöregionen

Projektmidler
\begin{tabular}{|l|c|c|c|c|c|} 
Valuta & Budget 2016 & Budget 2015 & Budget 2014 & Disp./bud. 14 & Budget disp. af \\
\hline DKK & 6.324 .000 & 6.324 .000 & 6.231 .000 & $92 \%$ & NSK/MR-SAM
\end{tabular}

Formål $\quad$ Formålet med NGO programmet er at styrke civilsamfund i Østersøregionen. Programmet støtter projekter, der gennem partnerskaber på tværs af regionen fremmer viden og erfaringsdeling mellem NGO'erne i de baltiske lande, Nordvestrusland, Polen og Hviderusland inden for en række prioriterede områder, f.eks. indenfor områder som miljø, omsorg for børn og andre udsatte grupper samt demokratiudvikling. Programmet administreres af Nordisk Ministerråds Sekretariat i København.

Budgetposten finansierer endvidere nordisk-baltiske NGO samarbejde.

I overensstemmelse med den af MR-SAM besluttede strategi er nedenstående mål fastlagt for 2016.

Forvaltnings- Nordisk Ministerråds Sekretariat er forvaltningsorgan for NGO programmet for organ

Østersøregionen.

Nordisk Ministerråds kontorer i Estand, Letland og Lituaen er forvaltningsorganer for nordisk-baltisk NGO samarbejde. 


\begin{tabular}{|c|c|c|}
\hline \multicolumn{3}{|l|}{ Mål og resultatopfølgning } \\
\hline 2016 - Mål & 2015 - Mål & 2014 - Opnåede resultater \\
\hline $\begin{array}{l}\text { At yde støtte til projekter med } \\
\text { fokus på udvikling af civilsam- } \\
\text { fundet i Østersøregionen. } \\
\text { Projekterne er indefor områder } \\
\text { som miljø, omsorg for børn og } \\
\text { andre udsatte grupper samt } \\
\text { demokratiudvikling. } \\
\text { At sprede kendskab til } \\
\text { programmet i regionen, således at } \\
\text { nye NGO’er bliver involveret. }\end{array}$ & $\begin{array}{l}\text { At yde støtte til projekter med } \\
\text { formålet at understøtte styrkelse } \\
\text { af civilsamfundet i } \\
\text { Østersøregionen. } \\
\text { At implementere de nye } \\
\text { ansøgningsprocedurer. }\end{array}$ & $\begin{array}{l}\text { Programmet ydede støtte til } 14 \\
\text { projekter med det samlede beløb } \\
\text { på DKK 5.343.233. } \\
\text { Ansøgningsprocessen foregik } \\
\text { gennem den nye online } \\
\text { ansøgningsportal. Portalen lettede } \\
\text { væsentligt administration af } \\
\text { programmet. }\end{array}$ \\
\hline
\end{tabular}

1-0970 Ministerrådets kontor i nordvästra Ryssland

Institution
\begin{tabular}{|l|c|c|c|c|c|} 
Valuta & Budget 2016 & Budget 2015 & Budget 2014 & NMR fin. 14 & Budget disp. af \\
\hline DKK & 0 & 9.496 .000 & 9.383 .000 & $0 \%$ & Institutionen
\end{tabular}

Formål Budgetposten har frem til og med 2015 finansieret driften af ministerrådets kontor i Nordvestrusland.

På baggrund af de russiske myndigheders beslutning om at registrere Nordisk Ministerråds kontor i Rusland som "NGO, der fungerer som udenlandsk agent” besluttede MR-SAM i marts 2015 at afvikle al udadvendt aktivitet under kontoret. Der vil dog indtil videre blive opretholdt en minimumstilstedeværelse i Nordvestrusland, som finansieres fra budgetpost 1-0810 Ministerrådets kontorer i Estland, Letland, Litauen og Nordvestrusland. Budgetændringerne vil også give plads til en styrket indsats ved kontorerne i Estland, Letland og Litauen som følge af ændringerne i regionen.

\begin{tabular}{|c|c|c|}
\hline \multicolumn{3}{|c|}{ Mål og resultatopfølgning } \\
\hline 2016 - Mål & 2015 - Mål & 2014 - Opnåede resultater \\
\hline $\begin{array}{l}\text { Budgetposten udgår fra } \\
\text { og med } 2016 .\end{array}$ & $\begin{array}{l}\text { Budgetposten finansierer kontorets drift. } \\
\text { Målet er at kontoret på en række } \\
\text { områder og i samarbejde med } \\
\text { sekretariatet i København udvikler det } \\
\text { nordisk-russiske samarbejde på en } \\
\text { række områder, herunder Programmet } \\
\text { for Kundskabsopbygning og netværk, } \\
\text { NGO-samarbejde og initiativer til støtte } \\
\text { for demokratiudvikling og civilsamfund, } \\
\text { aktiviteter indenfor } \\
\text { formandsskabsprogrammet i tæt } \\
\text { samarbejde med Danmarks } \\
\text { formandskab, Nordenfremmende } \\
\text { indsatser i tæt samarbejde med de } \\
\text { nordiske landes repræsentationer. } \\
\text { Arbejdet foregår indenfor NMRs } \\
\text { retningslinjer for samarbejde med } \\
\text { Nordvestrusland. }\end{array}$ & $\begin{array}{l}\text { Kontoret i Nordvestrusland har } \\
\text { gennemført og understøttet en lang } \\
\text { række aktiviteter i Nordvestrusland. } \\
\text { Kontoret har bidraget til at udvikle } \\
\text { netværk og gennemføre projekter af } \\
\text { fælles nordisk-russiske nytte, blandt } \\
\text { andet med fokus på demokratisk } \\
\text { samfundsudvikling, åbne relationer } \\
\text { og at fremme betingelserne for } \\
\text { økonomisk samarbejde og handel.. } \\
\text { Desuden har kontoret gennemført } \\
\text { aktiviteter indenfor } \\
\text { formandsskabsprogrammet i tæt } \\
\text { samarbejde med Islands } \\
\text { formandskab. }\end{array}$ \\
\hline
\end{tabular}


1-0810 Ministerrådets kontorer i Estland, Letland, Litauen og Nordvestrusland

Institution
\begin{tabular}{|l|c|c|c|c|c|} 
Valuta & Budget 2016 & Budget 2015 & Budget 2014 & NMR fin. 14 & Budget disp. af \\
\hline DKK & 15.330 .000 & 11.834 .000 & 11.694 .000 & $0 \%$ & Institutionen
\end{tabular}

Formål Ministerrådets kontorer i Estland, Letland og Litauen er en del af ministerrådets sekretariat og har til formål at fremme og udvikle det nordisk-baltiske samarbejde og bidrage til Nordenfremmende indsatser i samarbejde med de nordiske landes ambassader i landene.

NMR fastholder desuden indtil videre en minimumstilstedeværelse i Nordvestrusland i overenstemmelse med indgåede aftaler mellem NMR og Rusland (Memorandum of Understanding). Forøgelsen af budgetposten er begrundet med dette forhold og ønsket om en styrket indsats i forhold til Estland, Letland og Litauen. Forøgelsen er finansieret med midler fra budgetpost 0970.

I overensstemmelse med de af MR-SAM besluttede retningslinjer for samarbejdet med Estland, Letland og Litauen fra 2014 samt senere MR-SAM beslutninger med hensyn til aktiviteter i Rusland er der fastlagt nedennævnte mål for 2016.

\begin{tabular}{|c|c|c|}
\hline \multicolumn{3}{|l|}{ Mål og resultatopfølgning } \\
\hline 2016 - Mål & 2015 - Mål & 2014 - Opnåede resultater \\
\hline $\begin{array}{l}\text { Kontorerne skal bidrage til } \\
\text { NMRs arbejde med EU's } \\
\text { Østersøstrategi og den Nordlige } \\
\text { Dimension, videreudvikling af } \\
\text { eksisterende programmer for } \\
\text { nordisk-baltisk samarbejde, } \\
\text { aktiviteter indenfor } \\
\text { formandsskabsprogrammet i tæt } \\
\text { samarbejde med Finlands } \\
\text { formandskab samt } \\
\text { Nordenfremmende indsatser i tæt } \\
\text { samarbejde med de nordiske } \\
\text { landes ambassader i landene. } \\
\text { Opretholdelse af en } \\
\text { tilstedeværelse i Nordvestrusland, } \\
\text { der opfylder aftalerne med } \\
\text { Rusland (Memorandoum of } \\
\text { Understanding). }\end{array}$ & $\begin{array}{l}\text { Budgetposten finansierer } \\
\text { kontorernes drift. Kontorerne har } \\
\text { fokus på at bidrage til NMRs } \\
\text { arbejde med EU's Østersøstrategi } \\
\text { og den Nordlige Dimension, } \\
\text { videreudvikling af eksisterende } \\
\text { programmer for nordisk-baltisk } \\
\text { samarbejde, aktiviteter indenfor } \\
\text { formandsskabsprogrammet i tæt } \\
\text { samarbejde med Danmarks } \\
\text { formandskab samt } \\
\text { Nordenfremmende indsatser i tæt } \\
\text { samarbejde med de nordiske } \\
\text { landes ambassader. Arbejdet } \\
\text { foregår indenfor NMRs } \\
\text { retningslinjer for samarbejde med } \\
\text { Estland, Letland og Litauen. }\end{array}$ & $\begin{array}{l}\text { Kontorerne i Estland, Letland og } \\
\text { Litauen har gennemført og } \\
\text { understøttet en lang række } \\
\text { aktiviteter i landene. } \\
\text { Kontorerne har bidraget til at } \\
\text { udvikle netværk og gennemføre } \\
\text { projekter af fælles nordisk-baltisk } \\
\text { nytte, blandt andet med fokus på } \\
\text { migration og bekæmpelse af } \\
\text { menneskehandel. } \\
\text { Kontorerne har bidraget til } \\
\text { NMRs arbejde med EU’s } \\
\text { Østersøstrategi, navnlig inden for } \\
\text { kreative industrier (særligt Riga) } \\
\text { og bioøkonomi (Tallinn). } \\
\text { Kontoret i Vilnius har fået en } \\
\text { større rolle i administrationen af } \\
\text { NMRs Hvideruslandsaktiviteter. } \\
\text { Desuden har kontorerne } \\
\text { gennemført aktiviteter indenfor } \\
\text { formandsskabsprogrammet i tæt } \\
\text { samarbejde med Islands } \\
\text { formandskab. }\end{array}$ \\
\hline
\end{tabular}


1-0850 Internationellt samarbete

Projektmidler
\begin{tabular}{|l|c|c|c|c|c|} 
Valuta & Budget 2016 & Budget 2015 & Budget 2014 & Disp./bud. 14 & Budget disp. af \\
\hline DKK & 1.753 .000 & 1.753 .000 & 1.727 .000 & $100 \%$ & Generalsekretæren
\end{tabular}

Formål $\quad$ Formålet er at sikre international opmærksomhed på det nordiske samarbejde. Budgetposten finansierer indsatser, som fremmer Norden og Nordens virksomhed, som har fokus på kontaktskabelse og udvikling af nye initiativer, og initiativer i forbindelse med nye politiske udfordringer i Nordens naboområder eller udenfor Norden.

Der gives prioritet til samnordiske initiativer og initiativer af tværsektoriel karakter. Midlerne uddeles til udarbejdelse af informationsmateriale, rapporter, udredninger/analyser, afholdelse af konferencer, mm.

I overensstemmelse med MR-SAM beslutninger og strategier er de nedenfor nævnte mål fastlagt for 2016 .

\begin{tabular}{|c|c|c|}
\hline \multicolumn{3}{|l|}{ Mål og resultatopfølgning } \\
\hline 2016 - Mål & 2015 - Mål & 2014 - Opnåede resultater \\
\hline $\begin{array}{l}\text { At identificere og bidrage til } \\
\text { projekter der sikrer } \\
\text { internationalt opmærksomhed } \\
\text { på det nordiske samarbejde. }\end{array}$ & $\begin{array}{l}\text { At udvikle projekter, der } \\
\text { styrker Nordisk Ministerråds } \\
\text { og de nordiske landes rolle på } \\
\text { den internationale scene. Målet } \\
\text { er at styrke det nordiske } \\
\text { indsats. Relevante } \\
\text { samarbejdsprojekter vil blive } \\
\text { udviklet i løbet af året. }\end{array}$ & $\begin{array}{l}\text { Play Nordic: Projektet blev gennemført } \\
\text { af de nordiske ambassader og var det } \\
\text { første led i det fremtidige samarbejde } \\
\text { mellem NMRS og de nordiske } \\
\text { ambassader. } \\
\text { Forstudie "Lessons Learned from the } \\
\text { Nordic Fair Society” udarbejdet af } \\
\text { Crisis Management Initiative. } \\
\text { Forstudiet undersøger om og hvordan } \\
\text { nordiske erfaringer kan bidrage til at } \\
\text { opbygge "fair global society”. } \\
\text { Nordisk konference "Cool North - } \\
\text { Cultural Diplomacy in the Nordics”. } \\
\text { Konferencen undersøgte nordisk } \\
\text { udenrigs- og kulturelt diplomati og } \\
\text { præsentere de strategier, der har været } \\
\text { med til at skabe et succesfuldt nordisk } \\
\text { samarbejde med Rusland og de baltiske } \\
\text { lande. } \\
\text { Side eventet ”Addressing Overweight } \\
\text { and Obesity”. Eventet blev afholdt i } \\
\text { forbindelse med FAO/WHO- } \\
\text { konferencen ”Better nutrition - better } \\
\text { lives”. Det overordnede formål med } \\
\text { eventet var at foreslå fleksible politiske } \\
\text { rammer for at løse nutidens store } \\
\text { ernæringsudfordringer og identificere } \\
\text { prioriteter for styrket internationalt } \\
\text { samarbejde om ernæring. }\end{array}$ \\
\hline
\end{tabular}


$\underline{1-0870 \text { Arktiskt samarbetsprogram }}$

Projektmidler
\begin{tabular}{|l|c|c|c|c|c|} 
Valuta & Budget 2016 & Budget 2015 & Budget 2014 & Disp./bud. 14 & Budget disp. af \\
\hline DKK & 8.716 .000 & 8.716 .000 & 9.335 .000 & $94 \%$ & NSK/MR-SAM
\end{tabular}

Formål

Nordisk Ministerråds arktiske samarbejdsprogram 2015-2017 har til formål at skabe og/eller bidrage til bæredygtig udvikling i Arktis samt skabe nordisk nytte ved brug af midlerne i samarbejdsprogrammet til projekter, initiatitiver og tiltag. Målsætningen med det arktiske samarbejdsprogram er at understøtte processer, projekter og initiativer, som bidrager til ovennævnte. Endvidere skal samarbejdsprogrammet være med til at understøtte arbejdet i Arktisk Råd og andre relevante internationale og regionale fora.

I overensstemmelse med MR-SAMs godkendelse af det arktiske samarbejdsprogram for 2015-2017 blev der truffet beslutning om at øremærke 2 mio. DKK til "politiske prioriteringer”, således at der - overordnet set - arbejdes med en åben ansøgningsrunde (forvaltet af Nordregio) og en pulje for politiske prioriteringer (forvaltet af Nordisk Ministerråds sekretariat). Endvidere arbejdes der med nedennævnte fastlagte mål for 2016.

Forvaltnings- Nordregio er forvaltningsorgan for den åbne ansøgningsrunde af det arktiske organ samarbejdsprogram for 2015. Der er ikke truffet beslutning om forvaltningsorgan for 2016.

\begin{tabular}{|c|c|c|}
\hline \multicolumn{3}{|l|}{ Mål og resultatopfølgning } \\
\hline 2016 - Mål & 2015 - Mål & 2014 - Opnåede resultater \\
\hline $\begin{array}{l}\text { At gennemføre processen for den } \\
\text { åbne ansøgningsrunde rettidigt og } \\
\text { professionelt med henblik på at } \\
\text { give støtte til projekter, tiltag og } \\
\text { initiativer, der understøtter den } \\
\text { overordnede målsætning. } \\
\text { De politiske prioriteringer under } \\
\text { det arktiske samarbejde skal } \\
\text { bidrage til at løfte det nordiske } \\
\text { samarbejde højere op på den } \\
\text { nordiske og internationale } \\
\text { dagsorden i overensstemmelse } \\
\text { samarbejdsministrenes vision. } \\
\text { At formidle tungtvejende og } \\
\text { relevante resultater af projekter } \\
\text { støttet af det nordiske arktiske } \\
\text { samarbejde i centrale fora vedr. } \\
\text { Arktis (fx Arctic Circle, Arktisk } \\
\text { Råd, Arctic Frontiers etc.). } \\
\text { At bidrage til projekter, der } \\
\text { understøtter de nordiske landes } \\
\text { prioriteringer i det arktiske } \\
\text { samarbejde. }\end{array}$ & $\begin{array}{l}\text { Nytt nordisk arktisk program fra } \\
\text { 2015. Implementere og utvikle } \\
\text { initiativ og prosjekt i henhold til } \\
\text { prioriteringer i det nye program. }\end{array}$ & $\begin{array}{l}\text { I den åbne ansøgningsrunde for } \\
\text { det arktiske samarbejdsprogram } \\
\text { blev der bevilget midler til } 31 \\
\text { projekter (til i alt } 6.313 .000 \\
\text { DKK). } \\
\text { I puljen for de politiske } \\
\text { prioriteringer blev der bevilget } \\
\text { midler til overordnede projekter, } \\
\text { der bl.a. støttede udgivelsen af } \\
\text { den store opslagsbog (ca. } 600 \\
\text { sider) om sårbare natur- og } \\
\text { miljøområder i Arktis } \\
\text { "Biodiversity Assessment” og } \\
\text { bidrog til konferencer om hhv. } \\
\text { CSR og ligestilling i Arktis }\end{array}$ \\
\hline
\end{tabular}


1-0950 Hvideruslandsaktiviteter

Programlignende aktiviteter

\begin{tabular}{|l|c|c|c|c|c|} 
Valuta & Budget 2016 & Budget 2015 & Budget 2014 & Disp./bud. 14 & Budget disp. af \\
\hline DKK & 4.498 .000 & 4.498 .000 & 4.432 .000 & $98 \%$ & NSK/MR-SAM
\end{tabular}

Formål Formålet er at støtte aktiviteter, der fremmer demokratiudvikling i Hviderusland.

I overensstemmelse med de af MR-SAM besluttede retningslinjer for Hvideruslandsaktiviteter er nedenstående mål fastlagt for 2016.

Forvaltnings- Målene realiseret i koordination med NMRS kontor i Vilnius. organ

\begin{tabular}{|c|c|c|}
\hline \multicolumn{3}{|l|}{ Mål og resultatopfølgning } \\
\hline 2016 - Mål & 2015 - Mål & 2014 - Opnåede resultater \\
\hline $\begin{array}{l}\text { Drøfte fremtiden af Trust } \\
\text { Fondens mandat (EHU), der } \\
\text { udløber i slutningen af } 2016 . \\
\\
\text { Udvikle nye initiativer til } \\
\text { fremme af demokratisk } \\
\text { samfundsudvikling i } \\
\text { Hviderusland. }\end{array}$ & $\begin{array}{l}\text { I lyset af at Trust Fondens } \\
\text { mandat (EHU) udløber i } \\
\text { slutningen af 2016, vil fokus } \\
\text { være på fortsatte konsolidering } \\
\text { af virksomheden. } \\
\\
\text { Ligeledes vil udvikling af nye } \\
\text { aktiviteter prioriteres. } \\
\text { Aktiviteterne vil have til formål } \\
\text { at fremme en demokratisk } \\
\text { samfundsudvikling i } \\
\text { Hviderusland. }\end{array}$ & $\begin{array}{l}\text { Budgetposten støttede følgende } \\
\text { projekter og initiativer: } \\
\text { Det hviderussiske eksiluniversitet, } \\
\text { EHU, i Vilnius. EHU er et af de } \\
\text { vigtigste instrumenter, der kan } \\
\text { bidrage til en demokratisk } \\
\text { samfundsudvikling. EHU } \\
\text { administreres af Trust Fonden, som } \\
\text { NMRS har ansvar for. } \\
\text { Tv-stationen BELSAT. BELSAT } \\
\text { har til formål gennem forskellige } \\
\text { TV-udsendelser til den } \\
\text { hviderussiske befolkning at fremme } \\
\text { en uafhængig nyhedsformidling og } \\
\text { opinionsdannelse. Sendefladen } \\
\text { omfatter nyhedsprogrammer, } \\
\text { debatprogrammer og mere } \\
\text { underholdningsprægede } \\
\text { serieprogrammer. } \\
\text { European Cultural Festival i Minsk. } \\
\text { Formål var at informere forskellige } \\
\text { grupper i det hviderussiske samfund } \\
\text { om EU's initiativ om Eastern } \\
\text { Partnership (EaP) og ikke mindst } \\
\text { om selve EU. }\end{array}$ \\
\hline
\end{tabular}


1-0990 Samarbetet med Nordens grannar i Väst

Projektmidler
\begin{tabular}{|l|c|c|c|c|c|} 
Valuta & Budget 2016 & Budget 2015 & Budget 2014 & Disp./bud. 14 & Budget disp. af \\
\hline DKK & 1.602 .000 & 1.602 .000 & 1.578 .000 & $96 \%$ & NSK/MR-SAM
\end{tabular}

Formål

Samarbejde med Nordens naboer i Vest har til formål at stimulere øget samarbejde med naboer i vest samt udvikle nye samarbejdsprojekter. De midler, der står til rådighed, skal anvendes til aktiviteter og initiativer, som ligger i tråd med retningslinjerne for samarbejdet. Projekterne skal involvere én eller flere af naboerne i vest og forventes at kunne bidrage til et langvarigt samarbejde. NSK har besluttet, at det fra 2012 er et krav, at minimum $50 \%$ af et projekts budget skal medfinansieres fra partneren fra naboerne i vest.

I overensstemmelse med de besluttede retningslinjer er nedenstående mål fastlagt for 2016.

Forvaltnings- NMRS organ

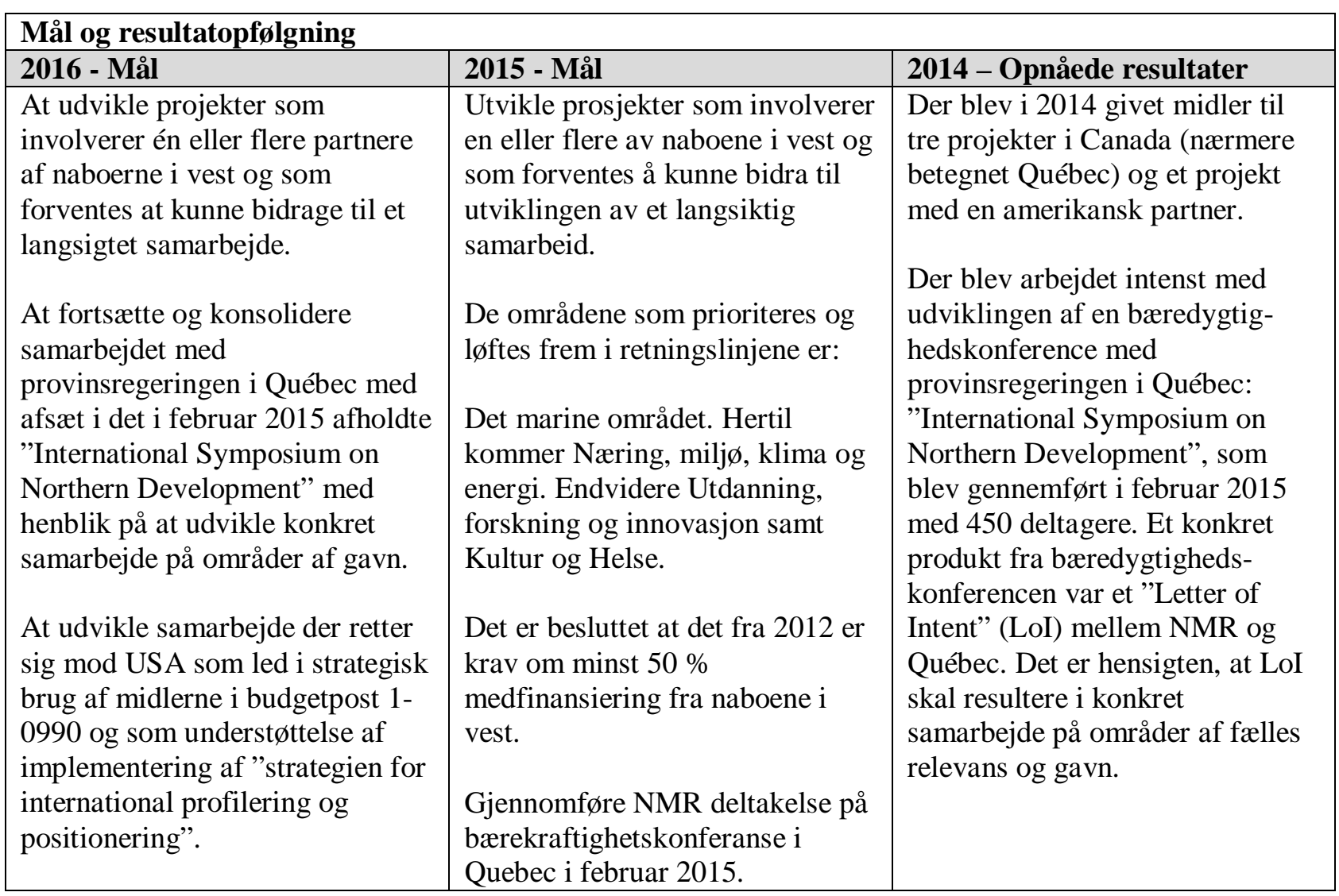




\section{Uddannelse og forskning}

\section{Generel indledning}

Formål og Ministerrådet for Uddannelse og Forskning (MR-U) har ansvar for Nordisk Ministerråds Fakta samarbejde om uddannelsespolitik og forskningspolitik, fra børnehave/førskole til grundskole, ungdomsuddannelser, voksenuddannelse og folkeoplysning samt højere uddannelse, ligesom MR-U koordinerer ministerrådets samarbejde om IT-politik og sprogpolitik. Formålet med MR-U's arbejde er at bidrage til et velfungerende, grænseløst nordisk uddannelses-, forsknings- og innovationsområde for at sikre, at Norden bliver en foregangsregion for kompetenceudvikling og forskning af høj kvalitet. Samtidig skal det fælles værdigrundlag, som ligger i en nordisk sprog- og kulturidentitet videreudvikles.

Strategiske målsætninger 2016
MR-U’s nye samarbejdsprogram fra 2015 ligger i forlængelse af den tidligere strategi for uddannelse og forskning, nordisk IT-politik og sprogpolitik.

MR-U fortsætter i 2016 sit samarbejde om konkrete nordiske uddannelsesinitiativer og uddannelsesprogrammer som Nordplus, Nordisk Sprogkoordination (NOSK), Nordisk Master og Nordisk Netværk for Voksnes Læring (NVL).

Målet er at skabe uddannelser, så alle børn, unge og voksne, drenge og piger, kan blive så dygtige som de kan i et godt psykisk og fysisk læringsmiljø, at betydningen af social baggrund mindskes, og at alle får mulighed for at lære og udvikle sig gennem hele livet.

Der vil være fokus på et stærkt nordisk videnssamarbejde, mødepladser for erfaringsudveksling, videndeling, læring og gensidig inspiration.

Indenfor højere uddannelse tager samarbejdet udgangspunkt i den øgede internationale konkurrence, som gør det centralt at påvise styrkeområder samt at bidrage til øget mobilitet inden for kundskabssektoren. Der vil være fokus på at styrke samarbejdet om pædagog- og læreruddannelsen, udøvelsen af pædagog- og lærerprofessionen samt efter- og videreuddannelse, så hele spektret af lærerfaget dækkes. Endvidere vil der være fokus på at styrke nordiske uddannelsesinstitutioners konkurrencekraft på det internationale marked samt at fremme mobiliteten i Norden eksempelvis gennem Nordic Master-programmet og Nordplus-programmet.

I 2016 videreføres arbejdet med at opsamle og formidle de væsentligste resultater af de tværsektorielle programmer Holdbar Nordisk Velfærd og Grøn Vækst, som MR-U har bidraget til (jf. budgetposterne 1-8210 og 1-8111).

I lyset af de senere års terrorbegivenheder i Norden besluttede MR-U i 2015 at sætte fokus på et styrket nordisk uddannelsessamarbejde om social mobilitet, inklusion og demokratisk dannelse. Som led i MR-SAM's initiativ i prioriteringsbudgettet om demokrati, inkludering, sikkerhed og bekæmpelse af antisemitisme fortsætter arbejdet i MR-U i 2016 blandt andet med et tværsektorielt initiativ, der skal kortlægge nordisk viden og formidle god praksis i de nordiske uddannelsessystemer og derigennem bidrage til at forebygge radikalisering af unge i Norden.

Det overordnede mål med det forskningspolitiske samarbejde er at styrke kvaliteten og synligheden af den nordiske forskning gennem tværvidenskabelige og sektorovergribende forskingsprogrammer. NordForsk koordinerer det nordiske forskningssamarbejde (jf. budgetpost 2-3100). I 2016 skal NordForsk gennemføre en vurdering af hvilke forskningsområder, som bør prioriteres i nordisk 
forskningssamarbejde fremover, inklusive samarbejdsorganernes virksomhed. Ud fra disse vurderinger skal NordForsk planlægge en eventuel finansiering af samarbejdsorganernes virksomhed fra og med 2017.

Fra og med 2014 har Nordisk Sommeruniversitet (NSU) ikke længere sin egen budgetpost. Videreudvikling af det nordiske forskningssamarbejde i regi af videnskabelige netværk er fortsat en prioritet for MR-U, men det sker ud fra forskningsrådenes prioriteringer og gennem NordForsk i en koordinerende rolle.

Det nordiske IT-samarbejde sigter på at gøre det lettere for borgere og virksomheder i Norden at bevæge sig på tværs af grænser og øge kvaliteten af den digitale offentlige forvaltning i Norden.

Det nordiske sprogsamarbejde vil fortsat fokusere på at videreudvikle det fælles værdigrundlag, som ligger i nordisk sprog- og kulturidentitet samt bidrage til et fokus på parallelsproglighed og at styrke børn og unges gensidige forståelse af dansk, norsk og svensk.

Som led i Nordisk Ministerråds strategi for international profilering og positionering af Norden, vil MR-U blandt andet have fokus på at undersøge forudsætningerne for profilering og efterspørgslen af nordiske uddannelser internationalt.

Samarbejdsministrene besluttede i 2015 at gennemføre en besparelse på 1 \% på det nordiske budget på i alt 9.318 TDKK. 30 \% af denne besparelse skal afholdes på budgettet for Uddannelse og forskning (MR-U) svarende til 2.795 TDKK. For MR-U's vedkommende vil denne besparelse blive udmøntet på budgetposterne 2-2505 Dispositionsmidler Uddannelse og forskning (400 TDKK), 2-2544 Det nordiske sprogsamarbejde (95 TDKK), 2-2553 Politikudvikling, Videnssamfund og ITinfrastruktur (8 TDKK), 2-3127 Politikudvikling voksnes læring (107 TDKK), 2-2513 Nordplus (674 TDKK) og 2-3100 NordForsk (1.511 TDKK).

Ministerrådets resultater i 2014
Resultatberetningen for MR-U beskriver her de resultater, som ligger ud over resultaterne beskrevet under de enkelte budgetposter. Der kan være tale om tværsektorielle resultater og aktiviteter der finansieres af andre sektorer, så som programmerne Holdbar Nordisk Velfcerd og Grøn Vcekst og samarbejdet med nabolandene.

På uddannelsesområdet har MR-U i regi af programmet Holdbar Nordisk Velfcerd blandt andet styrket arbejdet med entreprenørskab i folkeskolen, haft fokus på at mindske frafaldet i ungdomsuddannelserne gennem en vidensbank mod frafald samt bidraget til at belyse lærlinge- og praktikpladsproblematikken og øge kvaliteten i den arbejdsforlagte undervisning for unge og voksne gennem projektet Læring på arbejdsplads.

MR-U bidrager til at belyse ligheder og forskelle mellem de nordiske uddannelsessystemer gennem et mangeårigt samarbejde om fælles nordiske analyserapporter på skoleområdet. I 2014 blev rapportern Northern Lights on TIMSS and PIRLS 2011 præsenteret på en konference i Norge. TIMSS står for Trends in International Mathematics and Science Study, og PIRLS står for Progress in International Reading Literacy Study.

MR-U har i 2014 skabt rammer for nordisk netværksdannelse og videndeling på skoleområdet gennem den fælles nordisk konference Norden viser vej for praktikere på 0-18 års området. Konferencen blev gennemført med opbakning fra Nordisk Råd. Som opfølgning på konferencen har Danmark som et af sine tre-årige formandskabsprojekter 
inititeret et større nordisk videnssamarbejdsprojekt for praktikere.

Nordplus programmet har i 2014 bidraget til at udvikle uddannelserne i Norden og Baltikum og til at fremme nordisk-baltisk sprog- og kulturforståelse ved at yde tilskud til 395 projektsamarbejder, netværk og udvekslinger med deltagelse af over 2800 uddannelsesinstitutioner/organisationer. Se mere på www.nordplusonline.org.

På området højere uddannelse har MR-U bidraget til at fremme samarbejdet, arbejdsdeling og koncentration (SAK) mellem nordiske videregå ende uddannelsesinstutioner med fokus på små akademiske områder. Arbejdet har resulteret i et antal aktive samarbejder mellem de nordiske hovedstaders universiteter, blandt andet i fælles forskerskoler.

Det treårige projekt nordiska kunskapstriangelnätverk afsluttedes med en præsentation af konkrete, opnåede resultater og udvikling af metoder ved en konference i Europaparlamentet i november 2014.

I 2014 blev en ad hoc gruppe inden for området kvalitet i højere uddannelse nedsat. Gruppen, som består af et antal udvalgte eksperter fra nationale myndigheder, institutioner og departementer, skal foretage en afrapportering på sit arbejde ved udgangen af 2015.

NordForsk har i 2014 videreført de store samfinansierede nordiske programsatsninger: Topforskningsinitiativet, globaliseringsinitiativet, eScience, forskningsprogrammerne inden for uddannelsesforskning, samfundssikkerhed, Arktis samt inden for helse og velfærd. Endvidere har NordForsk inden for programmet Holdbar Nordisk Velfcerd initieret et nordisk samarbejde om register- og biobank- og interventionsforskning gennem en forbedret tilgang til nordiske datakilder. NordForsk har også etableret nye programmer om kønsbalance i forskningen, grøn vækst og neutronforskning. Inden for e-infrastruktur er der oprettet nye projekter, blandt andet om deling af følsomme oplysninger og nordiske Cloud-tjenester. For mere information, se budgetpost 2-3100 eller www.nordforsk.org.

Den nordisk-russiske samarbejdsaftale inden for højere uddannelse og forskning (Momorandum of Understanding) som gjaldt i 2012-2014 er forlænget i tre år, da ingen af parterne har opsagt aftalen. Rammerne for samarbejdet er beskrevet i et programdokument for 2012-2014. Samlet set er der uddelt nordiske midler til 16 projekter inden for højere uddannelse og til tre forskningsprojekter i løbet af programperioden.

I 2014 er der sket fremskridt for Baltic Ring, som er et projekt mellem de nordiske lande og øvrige lande omkring Østersøen om et højhastighedsnet, der skal understøtte forskningsinfrastrukturen og dermed forskningssamarbejdet i regionen. De dele af ringen, der kan etableres er nu etableret. Initiativet er derfor ikke længere et flagskibsprojekt i handlingsplanen for EU’s Østersøstrategi.

Fra 2014 er sprogsamarbejdet koordineret under et forvaltningsorgan med det formål at styrke og synliggøre sammenhængen i arbejdet. Ad hoc gruppen på sprogområdet, med medlemmer udpeget af henholdsvis EK-U og EK-U, har fulgt virksomheden i løbet af året. Ad hoc gruppens anbefalinger og redegørelse vil blive lagt frem i efteråret 2015.

Det nordiske IT-samarbejde har inden for rammerne af EU's eIDAS gennemført et nordisk projekt om grænseoverskridende offentlige digitale tjenester til borgere i Norden i 2014 (eID (digital signatur) og eSENS (digital infrastruktur)). Projekterne understøtter landenes implementering af EU's digitale indsatser og bidrager til at 
udvikle det europæiske samarbejde omkring grænseoverskridende digitale tjenester for borgere og virksomheder i Norden og EU. Arbejdet sammenfattes i en rapport, der lægges frem i juni 2015.

\begin{tabular}{|c|c|c|c|c|c|}
\hline & \multirow{2}{*}{$\begin{array}{r}\text { Budget } \\
2016 \\
\end{array}$} & \multirow{2}{*}{$\begin{array}{r}\text { Budget } \\
2015\end{array}$} & \multicolumn{2}{|c|}{ Difference } \\
\hline & & & & $+/-$ & $\%$ \\
\hline \multicolumn{2}{|c|}{ MR-U (TDKK) } & 225.321 & 228.116 & -2.795 & $-1,2 \%$ \\
\hline & Generelle utdannings- og forskningsinnsatser & 3.280 & 3.680 & -400 & $-10,9 \%$ \\
\hline \multirow[t]{2}{*}{$2-2505$} & Dispositionsmedel Utbildning och forskning & 3.280 & 3.680 & -400 & $-10,9 \%$ \\
\hline & Politikudvikling m.v. & 15.271 & 15.481 & -210 & $-1,4 \%$ \\
\hline $2-2544$ & Det nordiske sprogsamarbejde & 6.920 & 7.015 & -95 & $-1,4 \%$ \\
\hline $2-2553$ & Politikudvikling, Videnssamfund og IT-infrastruktur & 560 & 568 & -8 & $-1,4 \%$ \\
\hline \multirow[t]{2}{*}{$2-3127$} & Politikudvikling voksnes læring & 7.791 & 7.898 & -107 & $-1,4 \%$ \\
\hline & Mobilitets og netvæerksprogrammer & 76.861 & 75.735 & 1.126 & $1,5 \%$ \\
\hline $2-2513$ & Nordplus & 73.261 & 75.735 & -2.474 & $-3,3 \%$ \\
\hline \multirow[t]{2}{*}{ 2-2515 } & Nordic Master Programme & 3.600 & 0 & 3.600 & \\
\hline & Institution & 107.985 & 111.296 & -3.311 & $-3,0 \%$ \\
\hline \multirow[t]{2}{*}{$2-3100$} & NordForsk & 107.985 & 111.296 & -3.311 & $-3,0 \%$ \\
\hline & Forskning i øvrigt & 21.924 & 21.924 & 0 & $0,0 \%$ \\
\hline $2-3180$ & Nordisk Institut for Teoretisk Fysik (NORDITA) & 9.002 & 9.002 & 0 & $0,0 \%$ \\
\hline 2-3181 & Nordiska Institutet for Sjörett (NIfS) & 2.683 & 2.683 & 0 & $0,0 \%$ \\
\hline 2-3182 & Nordisk Institutt for Asiastudier (NIAS) & 4.253 & 4.253 & 0 & $0,0 \%$ \\
\hline 2-3184 & Nordisk vulkanologisk institut (NORDVULK) & 4.344 & 4.344 & 0 & $0,0 \%$ \\
\hline 2-3185 & Nordisk Samisk Institutt (NSI) & 1.642 & 1.642 & 0 & $0,0 \%$ \\
\hline \multicolumn{2}{|c|}{ Opdelt på kategorier } & 225.321 & 228.116 & $100 \%$ & $100 \%$ \\
\hline & Projektmidler & 10.760 & 11.263 & $4,8 \%$ & $4,9 \%$ \\
\hline & Programlignende aktiviteter & 106.576 & 105.557 & $47,3 \%$ & $46,3 \%$ \\
\hline & Institutioner & 107.985 & 111.296 & $47,9 \%$ & $48,8 \%$ \\
\hline
\end{tabular}

\section{Generelle forsknings- og uddannelsesindsatser}

2-2505 Dispositionsmidler Uddannelse og forskning

Projektmidler
\begin{tabular}{|l|c|c|c|c|c|} 
Valuta & Budget 2016 & Budget 2015 & Budget 2014 & Disp./bud. 14 & Budget disp. af \\
\hline DKK & 3.280 .000 & 3.680 .000 & 2.939 .000 & $84 \%$ & EK-U
\end{tabular}

Formål $\quad$ Formålet med dispositionsmidlerne er at finansiere politisk relevante initiatver, særligt med henblik på bredt at udmønte MR-U’s strategiske satsninger og udvalgte initiativer i det aktuelle formandskabsprogram samt til at gennemføre aktuelle studier og analyser samt evalueringer af projekter og programmer m.m.

Fra og med 2015 er denne budgetpost slået sammen med budgetpost 2-2560 Ad hoc arbrejdsgrupper på prioriterede områder. Alle midler er samlet på denne budgetpost. Formålet med ad hoc grupper er kunne finansiere arbejdgrupper, tænketanke m.m., der nedsættes med henblik på at frembringe aktuelle politiske indspil og underlag i MR-U’s arbejde. 
Som led i udmøntningen af en samlet besparelse på MR-U’s budget i 2016 er budgetposten beskåret med 400 TDKK svarende til 11\% i forhold til 2015.

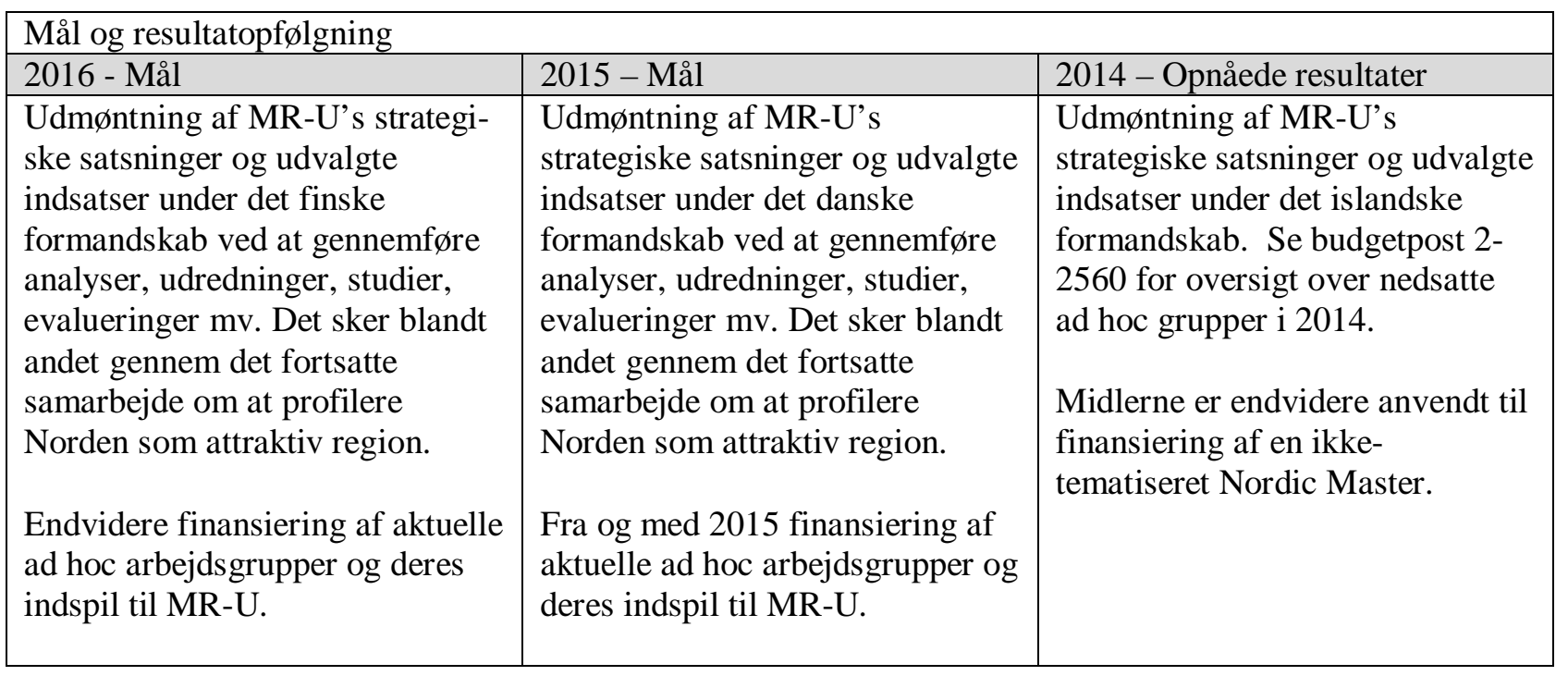

\section{Politikudvikling}

2-2560 Ad hoc arbejdsgrupper på prioriterede områder

Projektmidler

\begin{tabular}{|l|c|c|c|c|c|} 
Valuta & Budget 2016 & Budget 2015 & Budget 2014 & Disp./bud. 14 & Budget disp. af \\
\hline DKK & 0 & 0 & 2.595 .000 & $85 \%$ & EK-U
\end{tabular}

Formål Budgetposten er fra og med 2015 lagt sammen med budgetpost 2-2505

Dispositionsmidler - Uddannelse og Forskning.

\begin{tabular}{|l|l|l|}
\hline Mål og resultatopfølgning & 2015 - Mål & 2014 - Opnåede resultater \\
\hline 2016 - Mål & & I 2014 fandtes følgende Ad hoc \\
& & arbejdsgrupper under MR-U: \\
& Ad hoc-grupp för juridiska och \\
& administrativa hinder, Ad hoc gruppen \\
& for e-Science 2013, Ad hoc-gruppen på \\
& språkområdet, Ad hoc gruppen for \\
& revidering af Reykjavikdeklarationen, \\
& Ad hoc-grupp för vissa \\
& forskningsinfrastrukturfrågor och \\
& styrningsfrågor rörande NordForsk. \\
\hline
\end{tabular}




\section{2-2544 Det nordiske sprogsamarbejde}

Projektmidler
\begin{tabular}{|l|c|c|c|c|c|} 
Valuta & Budget 2016 & Budget 2015 & Budget 2014 & Disp./bud. 14 & Budget disp. af \\
\hline DKK & 6.920 .000 & 7.015 .000 & 6.911 .000 & $92 \%$ & ÄK-U
\end{tabular}

Formål

Det nordiske språksamarbeidet har til formål å styrke nabospråkforståelsen mellom dansk, norsk og svensk, både i tale og skrift. Språksamarbeidet skal videre ha et fokus på hvorvidt nordiske tiltak på språkområdet vil kunne bidra til å understøtte aktuelle nasjonale innsatser i oppfølgningen av Deklarasjon om nordisk språkpolitikk (språkdeklarasjonen). Formålet skal oppnås gjennom en styrket koordinering mellom avtalte aktiviteter og en tydelig sammenheng mellom aktiviteter og de politiske prioriteringer. Det legges særlig vekt på målgruppen barn og unge.

Forvaltningsorganet administrerer gjennom oppdraget Nordisk språkkoordinasjon koordineringsfunksjonen, selvstendige initiativer og øremerkede aktiviteter ivaretatt av sentrale aktører i språksamarbeidet. Forvaltningsorganet skal videre bidra til å styrke informasjons- og kommunikasjonsarbeidet på språkområdet. Oppdraget er beskrevet i rammeavtale for 2014 - 2018 .

Ekspertgruppen Nordens Sprogråd bidrar som faglig referansegruppe til kvalitetssikring av virksomheten

Ansvaret for språkområdet deles mellem MR-U (hovedansvar) og MR-K (sektoransvar).

Som led i udmøntningen af en samlet besparelse på MR-U’s budget i 2016 er budgetposten beskåret med 95 TDKK svarende til 1,4\% i forhold til 2015.

Forvaltnings- $\quad$ Foreningene Nordens forbund (FNF) organ

\begin{tabular}{|c|c|c|}
\hline \multicolumn{3}{|l|}{ Mål og resultatopfølgning } \\
\hline 2016 - Mål & 2015 - Mål & 2014 - Opnåede resultater \\
\hline $\begin{array}{l}\text { Å sikre en tydelig og synlig } \\
\text { sammenheng i } \\
\text { språksamarbeidet, inklusive det } \\
\text { tverrsektorielle perspektiv } \\
\text { gjenneom tiltak som bidrar til } \\
\text { en økt forståelse mellom } \\
\text { nabospråkene dansk, norsk og } \\
\text { svensk, i skrift og tale. } \\
\text { Målgruppene barn og unge og } \\
\text { deres undervisere er sentrale for } \\
\text { virksomheten på språkområdet, } \\
\text { og samvirket med relevante } \\
\text { nasjonale aktører er viktig i } \\
\text { kommunikasjons- og } \\
\text { informasjonsarbeidet. }\end{array}$ & $\begin{array}{l}\text { Målet er en styrket koordinering av } \\
\text { tiltak for å tydeliggjøre } \\
\text { sammenhengen og synligheten i } \\
\text { språksamarbeidet, inklusive det } \\
\text { tverrsektorielle perspektiv. } \\
\text { Tiltakene i språksamarbeidet skal } \\
\text { primært bidra til en økt forståelse } \\
\text { mellom nabospråkene dansk, norsk } \\
\text { og svensk, i skrift og tale. } \\
\text { Målgruppene barn og unge og } \\
\text { deres undervisere er sentrale for } \\
\text { virksomheten på språkområdet, og } \\
\text { samvirket med relevante nasjonale } \\
\text { aktører er viktig i } \\
\text { kommunikasjons- og } \\
\text { informasjonsarbeidet. } \\
\text { Språksamarbeidet skal videre der } \\
\text { det er mulig bidra til å understøtte } \\
\text { den nasjonale oppfølgning av } \\
\text { språkdeklarasjonen. }\end{array}$ & $\begin{array}{l}\text { Midlene har bidratt til å styrke } \\
\text { koordineringen mellom tiltakene } \\
\text { på språkområdet og bidra til en } \\
\text { tydeligere sammenheng i } \\
\text { realiseringen av MR-U’s } \\
\text { språkpolitiske prioriteringer og et } \\
\text { fokus på de tverrsektorielle } \\
\text { perspektiver i språksamarbeidet. } \\
\text { Målgruppene barn og unge og } \\
\text { deres undervisere er sentrale for } \\
\text { virksomheten på språkområdet, } \\
\text { og midlene har også bidratt til } \\
\text { utviklingen av Foreningene } \\
\text { Nordens egen læringsportal } \\
\text { Norden i Skolen. }\end{array}$ \\
\hline
\end{tabular}




\begin{tabular}{|l|l|l|}
\hline & $\begin{array}{l}\text { Ad hoc-gruppen på språkområdet } \\
\text { leverer i } 2015 \text { anbefalinger til det } \\
\text { øte fokus på språksamarbeidets } \\
\text { tverrsektorielle perspektiv. }\end{array}$ & $\begin{array}{l}\text { Det legges to redegjørelser om } \\
\text { språksamarbeidet frem for Nordisk } \\
\text { råd i } 2015 .\end{array}$ \\
\hline
\end{tabular}

Målene søges hovedsageligt realiseret gennem kurs og konferanser rettet mot lærere, lærer- og universitetsstudenter, og nettverksvirksomhet i Nettverket for språknemndene i Norden, Nordisk gruppe for parallellspråklighet og Nordisk tegnspråknettverk. Forvaltningsorganet skal bidra til å styrke informasjonsog kommunikasjonsarbeidet på språkområdet.

\section{$\underline{\text { 2-2553 Politikudvikling, Videnssamfund og IT-infrastruktur }}$}

Projektmidler
\begin{tabular}{|l|c|c|c|c|c|} 
Valuta & Budget 2016 & Budget 2015 & Budget 2014 & Disp./bud. 14 & Budget disp. af \\
\hline DKK & 560.000 & 568.000 & 560.000 & $100 \%$ & ÄK-U
\end{tabular}

Formål Det nordiske IT-samarbejde er organiseret i et uformelt forum for statslige IT-direktører i de nordiske lande. Formålet er overordnet at kvalificere, koordinere og videreudvikle Nordisk Ministerråds og de nordiske landes IT-politik inden for prioriterede indsatsområder, hvor der er synergi og nordisk nytteværdi. Det gælder særligt udviklingen af den digitale infrastruktur i Norden og i EU, hvor der er støtte nytte for landene i erfaringsudveksling, videndeling og koordinering af offentlige IT-løsninger.

Som led i udmøntningen af en samlet besparelse på MR-U’s budget i 2016 er budgetposten beskåret med 8 TDKK svarende til 1,4\% i forhold til 2015.

\begin{tabular}{|c|c|c|}
\hline \multicolumn{3}{|l|}{ Mål og resultatopfølgning } \\
\hline 2016 - Mål & 2015 - Mål & 2014 - Opnåede resultater \\
\hline $\begin{array}{l}\text { Formidle det nordiske eID- } \\
\text { projekt i landene og i relevante } \\
\text { fagministerråd samt sikre at } \\
\text { projektets resultaer integreres i } \\
\text { fyrtårnsprojektet 'Det digitale } \\
\text { Norden’ under Nordic Innovation } \\
\text { i } 2016 . \\
\text { Følge op på eID-projektets } \\
\text { resultater gennem afholdelse af } \\
\text { nordiske ekspert-workshops } \\
\text { omkring prioriterede } \\
\text { indsatsområder. }\end{array}$ & $\begin{array}{l}\text { Gennemføre og formidle et } \\
\text { noridsk IT-projekt, der skal } \\
\text { bidrage til at sikre at digitale } \\
\text { signaturer (eID) kan anvende på } \\
\text { tværs af grænser i Norden. } \\
\\
\text { Projektet sammenfattes i en } \\
\text { rapport med konkrete } \\
\text { anbefalinger til videre } \\
\text { implementering i landene, der } \\
\text { lægges frem for Nordisk } \\
\text { Ministerråd i juni } 2015 \text { til } \\
\text { behandling i relevante } \\
\text { fagministerråd }\end{array}$ & $\begin{array}{l}\text { IT-samarbejdet har i } 2014 \\
\text { gennemført et nordisk projekt om } \\
\text { eSENS, som led i EU's digitale } \\
\text { agenda for eGov. } \\
\text { På baggrund af en række } \\
\text { nordiske pilotforsøg har projektet } \\
\text { bidraget til at kvalificere og } \\
\text { udvikle grænseoverskridende } \\
\text { digitale tjenester for borgere og } \\
\text { virksomheder i Norden som led i } \\
\text { den europæiske indsats for at } \\
\text { skabe øget interoperabilitet i } \\
\text { mellem de europæiske digitale } \\
\text { tjenester. Projektet sammenfattes } \\
\text { i en rapport, der lægges frem for } \\
\text { IT-direktørerne i juni } 2015 .\end{array}$ \\
\hline
\end{tabular}




\section{2-3127 Politikudvikling voksnes læring}

Programlignende aktiviteter
\begin{tabular}{|l|c|c|c|c|c|} 
Valuta & Budget 2016 & Budget 2015 & Budget 2014 & Disp./bud. 14 & Budget disp. af \\
\hline DKK & 7.791 .000 & 7.898 .000 & 7.781 .000 & $100 \%$ & EK-U
\end{tabular}

Formål

Nordisk Ministerråds program for voksnes læring, Nordisk Netværk for Voksnes Læring (NVL), er en mødeplads for alle aktører involveret i voksnes læring i Norden. NVL skal følge og analysere udviklingen inden for området, bygge netværk, informere om nordisk samarbejde, sprede resultater og erfaringer fra rapporter, projekter og udviklingsarbejder på møder og konferencer samt bidrage med underlag til Nordisk Ministerråds arbejde. NVL skal også bidrage til at synliggøre resultater fra Nordplus Voksen, se budgetpost 2-2513.

Der er formuleret fire overordnede mål for NVL i programdokumentet for 2013-2017:

1) fremme udvikling og implementering af strategier for livslang læring og kompetenceudvikling, 2) bidrage til personlig udvikling og demokratisk deltagelse, 3) fremme samspillet med Nordplus programmet samt 4) informere struktureret og strategisk om erfaringer og resultater fra nordisk og europæisk samarbejde om voksnes læring.

Som led i udmøntningen af en samlet besparelse på MR-U's budget i 2016 er budgetposten beskåret med 107 TDKK svarende til 1,4\% i forhold til 2015.

Forvaltnings- Vox, nasjonalt fagorgan for kompetansepolitikk
organ

\begin{tabular}{|c|c|c|}
\hline \multicolumn{3}{|l|}{ Mål og resultatopfølgning } \\
\hline 2016 - Mål & 15 - Mål & 014 - Opnåede resultater \\
\hline $\begin{array}{l}\text { NVL vil i } 2016 \text { fortsætte sit } \\
\text { arbejde med at skabe bedre } \\
\text { muligheder for } \\
\text { efteruddannelse og } \\
\text { kompetenceudvikling for } \\
\text { voksne, fremme innovation og } \\
\text { entreprenørskab gennem } \\
\text { voksenuddannelsesindsatser } \\
\text { samt styrke voksnes } \\
\text { muligheder for vejledning og } \\
\text { validering af kompetencer } \\
\text { opnået i eller uden for } \\
\text { uddannelsessystemet. } \\
\text { NVL ska satsa på djupare } \\
\text { synergier och samarbete } \\
\text { mellan flera nätverk som kan } \\
\text { bidra till kompetensutveckling } \\
\text { av vuxenutbildare och } \\
\text { utveckling av } \\
\text { vuxeuntbildningssystemen. }\end{array}$ & $\begin{array}{l}\text { NVL’s verksamhet fokuserar på } \\
\text { teman; innovation i vuxnas } \\
\text { lärande, lärande i arbetslivet, } \\
\text { vägledning, validering och } \\
\text { flexibilitet i utbildningar. } \\
\text { NVL vill underlätta övergången } \\
\text { mellan arbetsliv och utbildning } \\
\text { genom insatser inom åtminstone } \\
\text { fyra av NVL:s nätverk. Här är det } \\
\text { viktigt att identifiera och } \\
\text { synliggöra utmaningar knutna till } \\
\text { för-bättring av dialogen och } \\
\text { samordning av insatser för } \\
\text { kompetensutveckling mellan } \\
\text { vuxenutbildningssystem och } \\
\text { arbetsplatslärande. } \\
\text { NVL ska satsa på att hitta } \\
\text { synergier och samarbete mellan } \\
\text { flera nätverk som kan främja } \\
\text { innovation i kompetensutveckling } \\
\text { av vuxenutbildare. Tre av NVL:s } \\
\text { nätverk vill i samarbete skapa } \\
\text { diskussion och nya idéer om hur }\end{array}$ & $\begin{array}{l}\text { NVL har samlat in och } \\
\text { systematiserat aktuella } \\
\text { forskningsresultat inom nordiskt } \\
\text { prioriterade teman och resultaten } \\
\text { presenteras på sida: } \\
\text { http://www.nordvux.net/tema/forsk } \\
\text { ningsresultater } \\
\text { Nätverk för professionalisering av } \\
\text { vuxenutbildare har under } 2014 \\
\text { analyserat erfarenheter från } \\
\text { lärmiljöer som visar på nytänkande } \\
\text { i hur man etablerar, organiserar } \\
\text { lärande och utbildning på ett } \\
\text { innovativt och entreprenöriellt sätt. } \\
\text { Nätverket har genomfört fem } \\
\text { studiebesök hos } \\
\text { utbildningsorganisationer eller } \\
\text { projekt som alla kännetecknas av } \\
\text { innovativa arbetsmetoder. Ett } \\
\text { forskarteam har sammanställt } \\
\text { resultaten och lyft fram särskilt } \\
\text { viktiga faktorer och principer för att } \\
\text { utveckla kompetenser som främjar } \\
\text { innovation och enterpreneurial }\end{array}$ \\
\hline
\end{tabular}




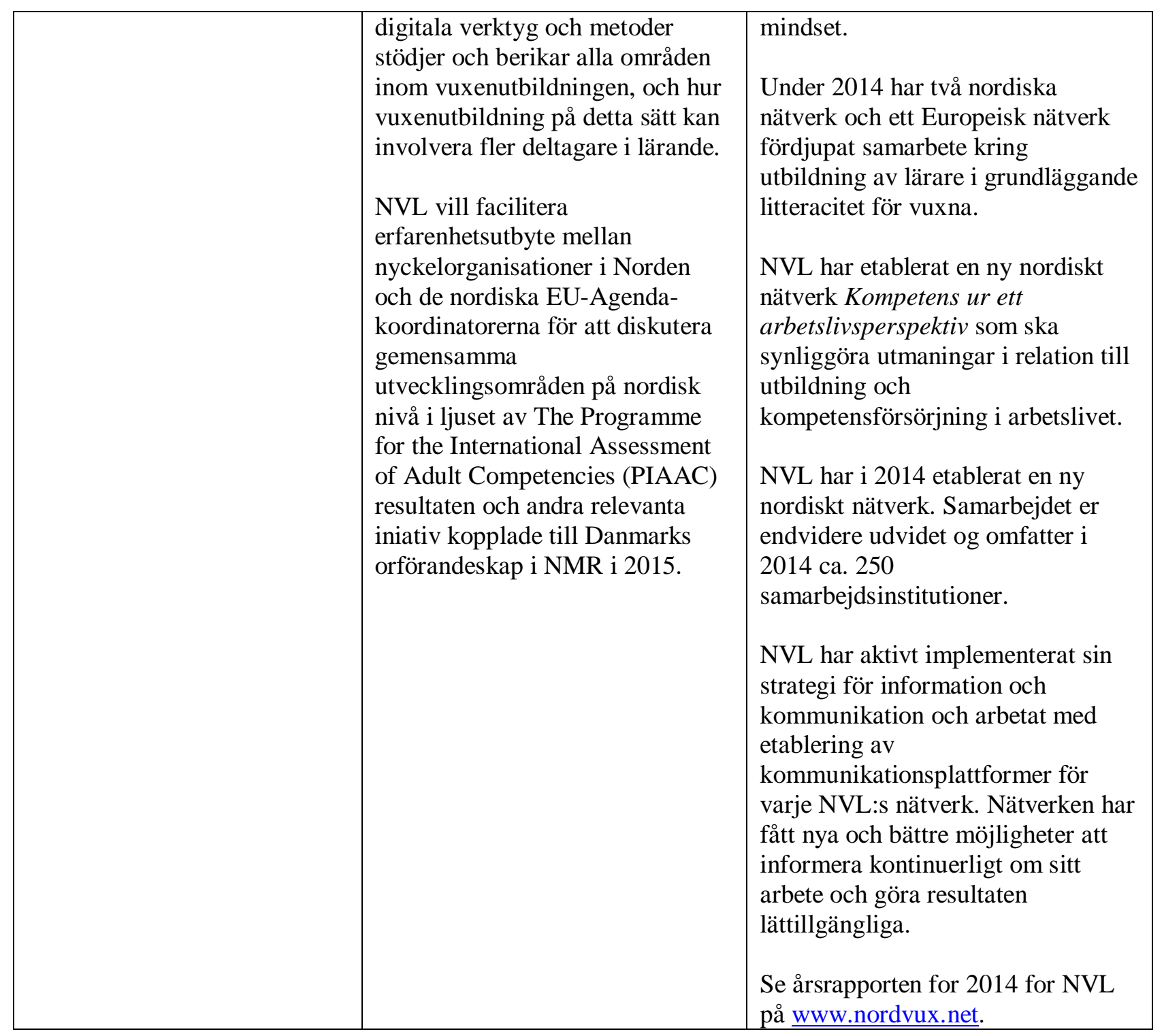

Mobilitets- og Netværksprogrammer

\section{$\underline{\text { 2-2513 Nordplus }}$}

Programlignende aktiviteter

\begin{tabular}{|l|c|c|c|c|c|} 
Valuta & Budget 2016 & Budget 2015 & Budget 2014 & Disp./bud. 14 & Budget disp. af \\
\hline DKK & 73.261 .000 & 75.735 .000 & 74.616 .000 & $100 \%$ & EK-U
\end{tabular}

Formål Nordplus er Nordisk Ministerråds største uddannelsesprogram inden for livslang læring. Nordplus består af fem delprogrammer Nordplus Horisontal, Nordplus Junior, Nordplus Højere Uddannelse, Nordplus Voksen og Nordplus Nordiske Sprog.

Formålet med Nordplus er fastlagt i programdokumentet for Nordplus:

Styrke og udvikle det nordiske udannelsessamarbejde og bidrage til at skabe et nordiskbaltisk udannelsesområde;

Støtte, bygge på, drage nytte af og sprede innovative produkter og processer på uddannelsesområdet gennem systematisk udveksling af erfaringer og god praksis; Bidrage til udviklingen af kvalitet og innovation i udannelsessystemerne for livslang 
læring i deltagerlandene gennem uddannelsessamarbejde, samt samarbejde med arbejdslivet om udviklingsprojekter, udveksling og netværksbygning;

Fremme nordiske sprog og kultur og gensidig nordisk-baltisk sproglig og kulturel forståelse;

Styrke sprogforståelsen særligt blandt børn og unge i de nordiske sprog, primært dansk, svensk og norsk;

Stimulere interessen for, kundskaben om og forståelsen for de nordiske sprog.

Som led i udmøntningen af en samlet besparelse på MR-U’s budget i 2016 er budgetposten beskåret med 674 TDKK svarende til 1\% i forhold til 2015. (Herudover er der i 2016 overført 1.800 TDKK til finansiering af den nye budgetpost, Nordic Master Programmet, se budgetpost 2-2515).

Forvaltnings-
organ

Nordplus administrationen er baseret på et konsortium udpeget af Nordisk Ministerråd, bestående af fem nationale programkontorer i hvert av de nordiske lande, som hver er udpeget som hovedadministratorer for et specifikt Nordplus delprogram. Nordplus administrationen inkluderer de tre nationale programkontorer for Nordplus i henholdsvis Estland, Letland og Litauen, samt de tre informationspunkter for Nordplus i Grønland, Færøerne og Åland, som er tilknyttet de nationale programkontorer i henholdsvis Danmark og Finland. En af de fem hovedadministratorer er af Nordisk Ministerråd udpeget som hovedkoordinator for Nordplus administrationen.

\begin{tabular}{|c|c|c|}
\hline \multicolumn{3}{|l|}{ Mål og resultatopfølgning } \\
\hline 2016 - Mål & 2015 - Mål & 2014 - Opnåede resultater \\
\hline $\begin{array}{l}\text { At støtte nordisk/baltisk } \\
\text { samarbejde inden for } \\
\text { uddannelsesområdet ved at styrke } \\
\text { kendskabet til og brugen af } \\
\text { Nordplus. } \\
\text { At styrke udbredelsen og } \\
\text { udnyttelsen af resultaterne af } \\
\text { Nordplus projekter. } \\
\text { At styrke kvaliteten af } \\
\text { ansøgninger og projekter under } \\
\text { Nordplus. } \\
\text { At øge yderligere } \\
\text { udnyttelsesgraden af Nordplus } \\
\text { programmets budget. } \\
\text { At beslutte og forberede } \\
\text { implementeringen af et nyt } \\
\text { Nordplus program fra } 2017 .\end{array}$ & $\begin{array}{l}\text { Målet er i 2015, at alle inden for } \\
\text { det nordiske og baltiske } \\
\text { uddannelsessamarbejde, som } \\
\text { Nordplus henvender sig til, } \\
\text { oplever at Nordplus er et } \\
\text { velfungerende program, som klart } \\
\text { bidrager til de opstillede formål. } \\
\text { Målet er, at programmets nye } \\
\text { hovedkoordinator i tæt } \\
\text { samarbejde med landenes } \\
\text { programkontorer og Nordplus } \\
\text { programkomite viderefører og } \\
\text { udvikler en smidig administration } \\
\text { og en strategisk styring af } \\
\text { programmet. } \\
\text { Målet er at drage nytte, viden og } \\
\text { indsigt af den evaluering, som i } \\
\text { 2014 pågår af hele Nordplus- } \\
\text { programmet. } \\
\text { Målet er derved at igangsætte } \\
\text { drøftelser og forslag til, hvordan } \\
\text { et nyt Nordplus-program kan } \\
\text { udformes fra } 2017 \text { og frem. }\end{array}$ & $\begin{array}{l}\text { For at støtte nordisk/baltisk } \\
\text { samarbejde inden for } \\
\text { uddannelsesområdet, er der } \\
\text { genom Nordplus i } 2014 \text { igangsat } \\
395 \text { godkendte projekter på } \\
\text { baggrund af i alt } 645 \text { modtagne } \\
\text { ansøgninger. } \\
\text { November } 2014 \text { blev det i } \\
\text { Vilnius arrangeret et } \\
\text { arbejdsseminar om uddannelse og } \\
\text { arbejdsliv, der sigtede på at skabe } \\
\text { input til, hvordan Nordplus bedre } \\
\text { kan understøtte samarbejder og } \\
\text { projekt, der søger at styrke } \\
\text { samspillet og sammenhængen } \\
\text { mellem uddannelse og arbejdsliv. } \\
\text { Seminaret, som Nordplus } \\
\text { programkomite og administration } \\
\text { stod bag, samlede i alt } 57 \\
\text { personer fra Norden og Baltikum. } \\
\text { Læs mere om blandt andet en } \\
\text { række gode projekt som er startet } \\
\text { på www.nordplusonline.org }\end{array}$ \\
\hline
\end{tabular}




\section{$\underline{\text { 2-2515 Nordic Master Programme }}$}

Programlignende aktiviteter
\begin{tabular}{|l|c|c|c|c|c|} 
Valuta & Budget 2016 & Budget 2015 & Budget 2014 & Disp./bud. 14 & Budget disp. af \\
\hline DKK & 3.600 .000 & 0 & 0 & $0 \%$ & EK-U
\end{tabular}

Formål Nordic Master är Nordiska ministerrådets utbildningsprogram. Minst tre nordiska universitet eller högskolor organiserar gemensamt två-åriga, engelskspråkiga masterprogram.

Internationalisera högre utbildning genom ett samspel av nordiska och icke-nordiska studenter, både från Europa och utifrån Europa.

Utveckla och underlätta samarbetet för universitet och högskolor i Norden genom att systematiskt uppmärksamma och lösa hinder och utmaningar i organiserandet av gemensamma studieprogram.

Erbjuda masteroprogram som baserar sig på excellens och hög kvalitet

Erbjuda forskningsbaserade program som möjliggör både en forskarkarriär och framgång i arbestlivet.

Utveckla samarbete mellan högre utbildningsinstitutioner och den nordiska industrin och arbetslivet.

Uppnå goda och mätbara resultat vad gäller studerandenas kompetenser och kunskaper, också gällande specifikt nordiska kompetenser och kunskaper.

Hjälpa studeranden och andra medverkande aktörer att bilda nyttiga nätverk.

Til finansiering af Nordic Master er der i 2016 overført 1.800 TDKK fra hver af budgetposter 2-2513 Nordplus og 2-3100 NordForsk.

Forvaltnings- $\quad$ Nordic Master administreras av Centret för internationell mobilitet i Finland (CIMO). organ

\begin{tabular}{|l|l|l|}
\hline Mål og resultatopfølgning & 2015 - Mål & 2014 - Opnåede resultater \\
\hline 2016 - Mål & & \\
\hline $\begin{array}{l}\text { Målsättningen för 2016 är att } \\
\text { utlysa minst tre nya Nordic } \\
\text { Master program. }\end{array}$ & \\
\hline
\end{tabular}

\section{$\underline{\text { 2-3100 NordForsk }}$}

Institution
\begin{tabular}{|l|c|c|c|c|c|} 
Valuta & Budget 2016 & Budget 2015 & Budget 2014 & NMR fin. 14 & Budget disp. af \\
\hline NOK & 119.983 .000 & 123.662 .000 & 123.859 .000 & $47 \%$ & Institutionen \\
\hline Modsv. DKK & 107.985 .000 & 111.296 .000 & 121.382 .000 & &
\end{tabular}

Formål $\quad$ NordForsk koordinerar Nordiskt samarbete om forskning och forskningsinfrastruktur. Målet är att främja kvalitet och effektivitet samt relevans av nordiskt forskningsamarbete.

Det gäller såväl områden där de nordiska länderna har en internationell styrkeposition som strategiskt betydelsefulla områden, där en gemensam nordisk satsning behövs för att bygga upp en forsknings- och utbildningskompetens av internationell kvalitet och styrka. 
NordForsk ska främst utforma initiativen utifrån de nationella forskningsfinansierande organens prioriteringar. Förslag till initiativ kan också identifieras av forskningsvärlden och Nordiska ministerrådet. Samarbetet ska kunna omfatta såväl grundforskning som mer praktiskt tillämpade inriktningar.

Som led i udmøntningen af en samlet besparelse på MR-U’s budget i 2016 er budgetposten beskåret med 1.511 TDKK svarende til 1\% i forhold til 2015. (Herudover er der i 2016 overført 1.800 TDKK til finansiering af den nye budgetpost Nordic Master Programmet, se budgetpost 2-2515).

Kontaktperiode NordForsk har ett treårigt mål- och resultatkontrakt för perioden 2015-2017. og -status

\begin{tabular}{|c|c|c|}
\hline \multicolumn{3}{|l|}{ Mål og resultatopfølgning } \\
\hline 2016 - Mål & 2015 - Mål & 2014 - Opnåede resultater \\
\hline $\begin{array}{l}\text { Stärka den nordiska forskningens } \\
\text { kvalitet och synlighet genom } \\
\text { storskaliga, tvärvetenskapliga och } \\
\text { sektorövergripande } \\
\text { forskningsprogram formulerade i } \\
\text { syfte att tackla stora samhälleiga } \\
\text { utmaningar och försäkra sig om } \\
\text { en uthållig samhällsutveckling. } \\
\text { NordForsk kommer att fortsätta } \\
\text { sin redan inledda satsning på } \\
\text { hälsa- och välfärdsområdert. } \\
\text { Målet är att den nya kunskap som } \\
\text { frambringas ska bidra till } \\
\text { kostnadseffektivitet och ökad } \\
\text { kvalitet inom de 21:a } \\
\text { århundradets nordiska } \\
\text { välfärdstater. } \\
\text { Speciellt viktigt är att utnyttja } \\
\text { den unika tillgång på data, t.ex. } \\
\text { de biobanker, arbetsmarknads- } \\
\text { och utbildnings- } \\
\text { migrationsregister som finns i } \\
\text { Norden till sin fulla potensial och } \\
\text { därigenom bidra till } \\
\text { utvecklandet av det } 21: a \\
\text { århundradets nordiska } \\
\text { välfärdstater. } \\
\text { Fortsätta att utveckla } \\
\text { forskningsprogram som bidrar till } \\
\text { att skapa kritisk massa inom } \\
\text { prioriterade områden t.ex } \\
\text { eScience och Morgondagens } \\
\text { utbildning. } \\
\text { Inleda satsningar på strategiskt } \\
\text { universitetssamarbete som syftar } \\
\text { till framväxt av }\end{array}$ & $\begin{array}{l}\text { Målet år } 2015 \text { är att vidareföra } \\
\text { NordForsks uppdrag baserat på } \\
\text { de uppdaterade stadgarna från år } \\
2014 \text { samt in i en ny } \\
\text { strategiperiod. } \\
\text { Målet är att främja nordiskt } \\
\text { forskningssamarbete bl.a. genom } \\
\text { att: } \\
\text { Stärka den nordiska forskningens } \\
\text { kvalitet, styrka och synlighet } \\
\text { genom stärkt } \\
\text { forskningssamarbete över } \\
\text { landsgränser. Det realiseras } \\
\text { främst genom storskaliga, } \\
\text { tvärvetenskapliga och } \\
\text { tvärsektoriella forskningsprogram } \\
\text { som svarar på stora samhälleliga } \\
\text { utmaningar; aktiviteter som } \\
\text { bidrar till den nordiska } \\
\text { forskningens synlighet och } \\
\text { konkurrenskraft i Europa och } \\
\text { globalt; samt skapande av kritisk } \\
\text { massa inom prioriterade } \\
\text { områden. } \\
\text { Främja nordiskt samarbete kring } \\
\text { väsentlig forskningsinfrastruktur } \\
\text { och på så sätt bidra till } \\
\text { högkvalitativ forskning samt } \\
\text { effektivt utnyttjande av resurser; } \\
\text { Det realiseras huvudsakligen via } \\
\text { gemensamma nordiska } \\
\text { satsningar, bidrag till etablering } \\
\text { av relevant } \\
\text { forskningsinfrastruktur samt } \\
\text { harmonisering av existerande } \\
\text { infrastrukturer, t.ex. hälso- och } \\
\text { sociala register. }\end{array}$ & $\begin{array}{l}\text { Utvärderat satsningarna på } \\
\text { Välfärd, Mat, Kost och Hälsa } \\
\text { samt Toppforskningsinitiativet } \\
\text { inom Klimat, Energi och Miljö. } \\
\text { Utvärderingarna visar att det varit } \\
\text { svårt att goda resultat inte kunnat } \\
\text { uppnås utan nordiskt samarbete. } \\
\text { En annan effekt konstaterades } \\
\text { vara av samarbetet att en ung } \\
\text { generation forskare utbildats och } \\
\text { fått tillgång till viktiga } \\
\text { internationella nätverk. } \\
\text { Inom nationellt prioriterade } \\
\text { områden har nya } \\
\text { forskningssatsningar gjorts när } \\
\text { det gäller Jämställdhet, Grön } \\
\text { Tillväxt och Neutronforskning. } \\
\text { Alla dessa initiativ har } \\
\text { omfattande nationell } \\
\text { medfinasiering. } \\
\text { En uppdaterad eScience Action } \\
\text { Plan har utarbetats. Fokus är på } \\
\text { eScience, e-Infrastruktur och } \\
\text { utbildning. Den lägger grunden } \\
\text { för utveckling av forskningen och } \\
\text { forskningsmetoderna i den nya } \\
\text { digitala världen. Inom e- } \\
\text { Infrastruktur nya projekt } \\
\text { igångsatts, bland annat inom } \\
\text { delning av sensitiva data samt } \\
\text { inom nordiska moln tjänster. } \\
\text { Innlett samarbetet om sociala- } \\
\text { och hälsoregister, biobanker, } \\
\text { samt vidarefört nordisk } \\
\text { samarbete om kliniska studier. I } \\
\text { anslutning härtill har speciella } \\
\text { analyser gjorts av legala och }\end{array}$ \\
\hline
\end{tabular}


gränsöverskridande allianser och infrastrukturkonsortier. Det nordiska mervärdet är ökad kvalitet och effektivitet genom gränsöverskidande samarbete.

Ett viktigt mål för all vår verksamhet är att främja internationellt samarbet för att göra nordisk forskning och nordiska forskare internationellt ledande.

Ordna mötesplatser där nordiska beslutsfattare möter forskare. Ämnen som kan behandlas är ny kunskap om Samhällssäkerhet, Ansvarig utveckling av Arktis, klimatförändringar etc.

Ny kunskap ska också göras offentligt tillgänglig för både forskare och medborgare i Norden.

All verksamhet sker på grundlag av nationella prioriteringar.

NordForsk ska genomföra en utvärdering av

samarbetsorganens verksamhet vad gäller vetenskaplig kvalitet och nordiskt mervärde.

NordForsk ska också genomföra en värdering av vilka ämnen/fält/områden som bör prioriteras i nordisk forskningssamverkan framöver, inklusive samarbetsorganens verksamheter.
Bidra till att ta fram

kunskapsgrundlag för samhällelig nytta (beslutsfattare inom offentlig och privat sektor). Det realiseras främst genom aktiviteter som ökar det nordiska forsknings- och forskningsinfrastruktursamarbets synlighet; analyser och rådgivning; samt skapande av ett forum för forskningspolitisk debatt.

Säkra en god förankring av institutionens aktiviteter i nationella prioriteringar och ett effektivt utnyttjande av resurser.

NordForsk vill också prioritera och bidra till ett ökat och effektivt administrativt samarbete mellan de nordiska institutionerna i Oslo. etiska frågor av stor betydelse för utvecklingen av detta område.

Bidragit till förverkligandet av ett europeiskt forskningsrum genom vidareutveckling av NordForsks aktiviteter. I tillägg har NordForsk styrkt användningen av existerande program som utgångspunkt för samarbete med länder utanför Norden.

Härigenom har NordForsk bidragit till att förverkliga visionen om ett gränslöst, synligt och innovativt Norden.

Särskilt dialogen med "Science Europe" och "European University Association" har gjort det möjligt för NordForsk att utveckla principer för förverkligade av jämställdhet och öppen tillgång till publikationer samt data samt för öppen internationell rekrytering $\mathrm{i}$ alla NordForsks aktiviteter.

\section{Forskning i øvrigt}

\section{$\underline{\text { 2-3180 Nordisk Institut for Teoretisk Fysik (NORDITA) }}$}

Programlignende aktiviteter

\begin{tabular}{|l|c|c|c|c|c|} 
Valuta & Budget 2016 & Budget 2015 & Budget 2014 & Disp./bud. 14 & Budget disp. af \\
\hline DKK & 9.002 .000 & 9.002 .000 & 8.869 .000 & $100 \%$ & Styret for Nordita
\end{tabular}

Formål

Norditas främsta uppgift är grundforskning på högsta internationella nivå inom teoretisk fysik. Institutet bedriver även vetenskapliga program med stort nordiskt deltagande bestående av månadslånga perioder av intensiv forskning kring ett specifikt tema. 
Nordita driver ett stipendiatprogram för högt meriterade unga forskare och för utbildning av doktorander vid kurser och forskarskolor samt genom forskarhandledning.

Forvaltnings- Kungliga Tekniska Högskolan organ

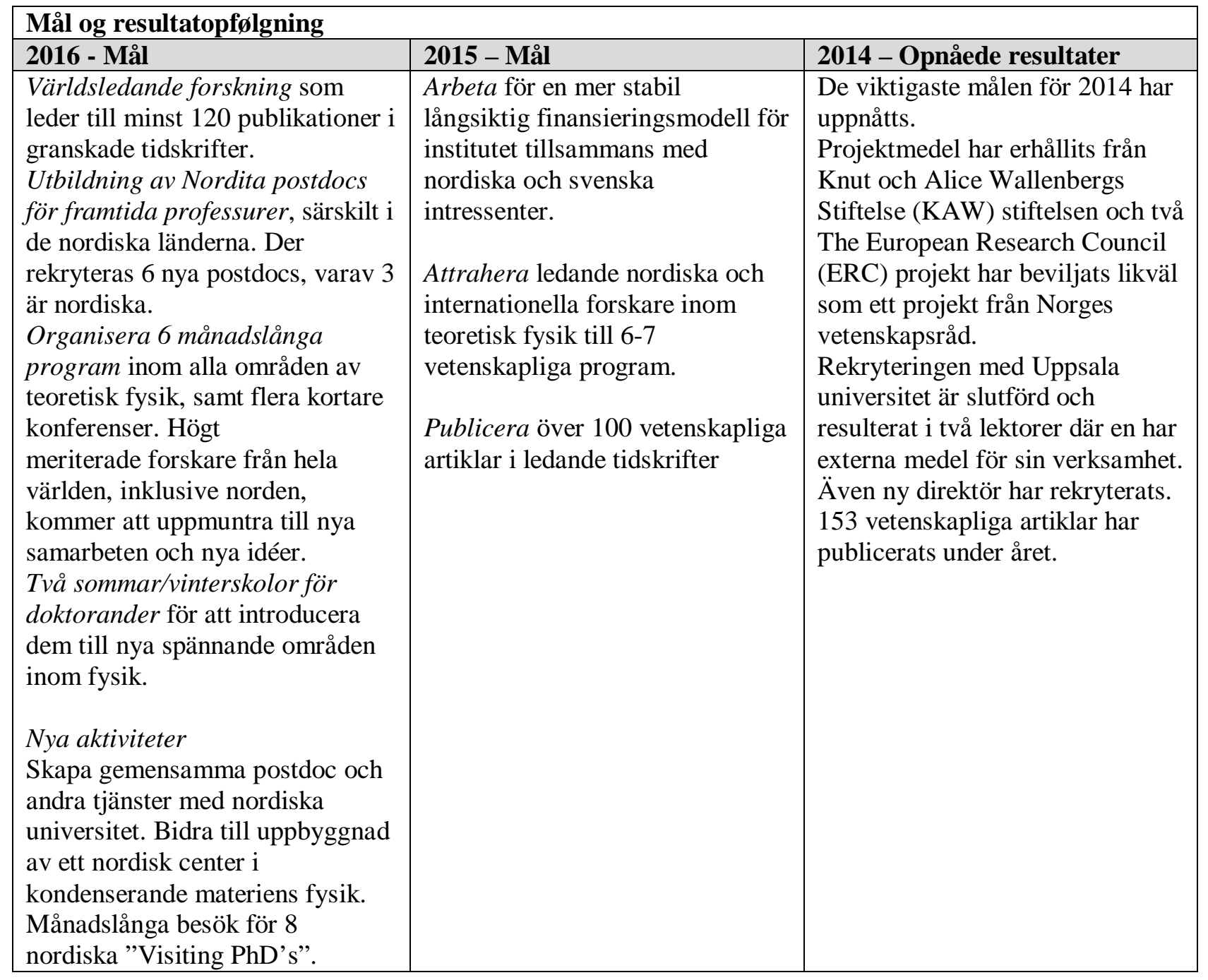

Målen skall förverkligas främst genom gruppforskning och individuell forskning inom flera områden i teoretisk fysik, samt genom att organisera vetenskapliga aktiviteter som program och konferenser samt forskarskolor. Samt colloqiuim verksamhet. Forskarutbildning på doktorand och postdoktorsnivå är viktiga delar i aktiviteterna och gäst program för nordiska och internationella forskare. Vidare genom marknadsföring i de nordiska länderna öka kunskapen om Nordita.

\section{2-3181 Nordisk Institutt for sjørett (NIfS)}

Programlignende aktiviteter

\begin{tabular}{|l|c|c|c|c|c|} 
Valuta & Budget 2016 & Budget 2015 & Budget 2014 & Disp./bud. 14 & Budget disp. af \\
\hline DKK & 2.683 .000 & 2.683 .000 & 2.643 .000 & $98 \%$ & Styret for NIfS
\end{tabular}

Formål Nordisk institutt for sjørett har som formål å fremme forskning og undervisning i de nordiske land i sjørett, alminnelig transportrett, energi- og petroleumsrett og beslektede 
fagområder. Instituttet skal videre opprettholde en høy kompetanse i alminnelig formuerett.

Forvaltnings- Oslo Universitet organ

\begin{tabular}{|c|c|c|}
\hline \multicolumn{3}{|l|}{ Mål og resultatopfølgning } \\
\hline 2016 - Mål & 2015 - Mål & 2014 - Opnåede resultater \\
\hline $\begin{array}{l}\text { Instituttet vil videreføre } \\
\text { ansettelse av en professor II fra } \\
\text { Finland, en forsker II fra } \\
\text { Finland (via InterTran } \\
\text { prosjektet i Helsinki), en } \\
\text { professor II fra Danmark samt } \\
\text { videreføring av støtte til nordisk } \\
\text { samarbeid i forskningsnettverk. } \\
\text { Et mål for } 2016 \text { er at } \\
\text { resultattallene ligger på snittet } \\
\text { for de siste } 5 \text { år, som bl.a. vil } \\
\text { innebære: } \\
\text { Innleverte doktoravhandlinger } 2 \\
\text { Publikasjoner i serie } 14 \\
\text { Bøker } 4 \\
\text { Publiserte manus } 45 \\
\text { Studentavhandlinger } 31 \\
\text { Kurs } 12 \\
\text { Utlån bibliotek } 6766\end{array}$ & $\begin{array}{l}\text { Det langsiktige mål er å bevare og } \\
\text { videreutvikle NIfS som nordisk } \\
\text { kompetansesenter i sjørett. Dette } \\
\text { forutsetter at forskning, } \\
\text { undervisnings- og } \\
\text { kompetanseindikatorer holdes } \\
\text { stabilt innenfor den naturlige } \\
\text { variasjon som ligger i } \\
\text { virksomhetens natur. } \\
\text { Et mål for } 2015 \text { er at } \\
\text { resultattallene ligger på snittet for } \\
\text { de siste } 5 \text { år, som bl.a. vil } \\
\text { innebære: } \\
\text { Innleverte doktoravhandlinger } 2 \\
\text { Publikasjoner i serie } 11 \\
\text { Bøker } 7 \\
\text { Publiserte manus } 50 \\
\text { Studentavhandlinger } 31 \\
\text { Kurs } 12 \\
\text { Utlån bibliotek } 7500 .\end{array}$ & $\begin{array}{l}\text { Antall innleverte } \\
\text { doktoravhandlinger: ingen } \\
\text { Kommentar: Sterk forsinkelse i } \\
\text { noen phd prosjekter } \\
\text { Utgitte publikasjoner i serie } 20 \\
\text { Utgitte bøker (inklusive pensum) } 2 \\
\text { Antall publiserte manuskripter på } \\
\text { engelsk } 19 \\
\text { Publiserte manuskripter/ferdige } \\
\text { manuskr. } 38 \\
\text { Innleverte studentavhandlinger } 32 \\
\\
\text { Deltagere i forskerutdanning } 8 \\
\text { Nordiske studenter (hvorav } \\
\text { Nordplus) } 32 \text { (26) } \\
\text { Gjennomførte kurs } 15 \\
\text { Studenter til eksamen } 626 \\
\text { Antall kveldsseminarer } 9 \\
\text { Deltagere på kveldsseminar } 288 \\
\text { Mottakere av seminarmateriale } \\
1570 \\
\text { Antall utlån biblioteket } 5431 \\
\text { Tilvekst til biblioteket } 400 \\
\text { Deltagelse i internasjonale nettverk } \\
\text { o.l.13 }\end{array}$ \\
\hline
\end{tabular}

Målene søkes realisert hovedsakelig via forskning og forskerutdanning, undervisning i forskjellige valgfag, videreutdanning gjennom seminarer og kurs, opprettholdelse av fagbibliotek, rådgivende virksomhet i forhold til offentlige myndigheter, advokater og de aktuelle næringsinteresser, internasjonalt samarbeide og publisering og annen forskningsformidling.

\section{$\underline{\text { 2-3182 Nordisk Institut for Asienstudier (NIAS) }}$}

\section{Programlignende aktiviteter}

\begin{tabular}{|l|c|c|c|c|c|} 
Valuta & Budget 2016 & Budget 2015 & Budget 2014 & Disp./bud. 14 & Budget disp. af \\
\hline DKK & 4.253 .000 & 4.253 .000 & 4.190 .000 & $98 \%$ & NIAS styre
\end{tabular}

Formål

NIAS er en nordisk kundskabs- og ressourceplatform som fokuserer på det moderne Asien og relationerne mellem Norden og Asien. NIAS udfører forskning, publicerer og formidler asienkundskaber, og er et tværfagligt mødested for nordiske asienprojekter og netværk samt for internationale forskere. Det digitale bibliotek står til rådighed for 26 nordiske universiteter og centre, og stipendieprogrammet tilbyder ophold ved NIAS. 
Forvaltnings- Københavns Universitet organ

\begin{tabular}{|c|c|c|}
\hline \multicolumn{3}{|l|}{ Mål og resultatopfølgning } \\
\hline 2016 - Mål & 2015 - Mål & 2014 - Opnåede resultater \\
\hline $\begin{array}{l}\text { Fastholde og udvikle } \\
\text { eksisterende kerneaktiviteter: } \\
\text { styrke } \\
\text { forskningsinfrastrukturen, } \\
\text { informations digitalisering, } \\
\text { open acces, og gæsteforsker } \\
\text { programmet for nordiske og } \\
\text { asiatiske forskere. } \\
\text { Etablere 1-3 interdisciplinære } \\
\text { og tvær-kulturelle forsknings- } \\
\text { projekter med fokus på } \\
\text { relationerne mellem Asien og } \\
\text { Norden. } \\
\text { Fremme kundskaber om Asiens } \\
\text { samfund, kultur, økonomi og } \\
\text { politik, specielt udenfor de } \\
\text { traditionelle Asienstudier, } \\
\text { herunder stå til rådighed for } \\
\text { samfundsinstitutioner og } \\
\text { erhvervsliv. } \\
\text { Udgive en skriftserie (digitalt \& } \\
\text { papir) om asiatiske forhold af } \\
\text { særlig interesse for nordiske } \\
\text { offentlige institutioner og } \\
\text { private virksomheder. } \\
\text { Fortsat styrke samarbejdet med } \\
\text { nordiske institutioner om } \\
\text { udvikling af asienkundskaber. }\end{array}$ & $\begin{array}{l}\text { Viden om Asien. Fokusere på } \\
\text { Asien og Norden/Europa i et } \\
\text { komparativt perspektiv. Et } \\
\text { fokusområde vil være relationer } \\
\text { mellem Norden og Asien. } \\
\text { Arbejdet hermed vil inddrage } \\
\text { nordiske og asiatiske forskere, i et } \\
\text { tværkulturelt og interdisciplinært } \\
\text { samarbejde. } \\
\text { Udvikle et nordisk/europæisk } \\
\text { center of excellence indenfor } \\
\text { Asienstudier i et tæt samarbejde } \\
\text { med vore partnere i NNC } \\
\text { (Norden) og EA (Europa), samt i } \\
\text { Asien. } \\
\text { Nordisk/Europæisk satsning } \\
\text { indenfor Asienforskning. NIAS } \\
\text { skal udgøre en naturlig base for et } \\
\text { nordisk/europæisk center of } \\
\text { excellence, via netværk i Norden, } \\
\text { Europa og Asien. }\end{array}$ & $\begin{array}{l}\text { Modtog } 42 \text { nordiske MA/PhD } \\
\text { kandidater, afholdt } 22 \text { seminarer } \\
\text { internt, og } 43 \text { seminarer eksternt. } \\
\text { NIAS forskere publicerede } 5 \\
\text { monografier, } 25 \text { artikler i } \\
\text { kvalitetstidsskrifter, } 16 \text { kapitler i } \\
\text { videnskabelige værker, samt } 28 \\
\text { andre udgivelser. } 90 \text { interviews i } \\
\text { nordiske medier. } 13 \text { NIAS Press } \\
\text { monografier, } 8 \text { af dem nordiske. } \\
\text { Biblioteket digitalt. Antal brugere } \\
\text { stigende: NIAS: } 24.357 \text { hits, Asia } \\
\text { Portal: } 16.272 \text { og NIAS Press: } \\
\text { 13.539. NIAS med i det nordiske } \\
\text { open acces projekt (DiVA) det } \\
\text { digitale videnskabelige arkiv. } \\
\text { Årets NNC konference og PhD } \\
\text { kursus afholdt i Island med stor } \\
\text { Nordisk og Asiatisk deltagelse. } \\
\text { Det ny Fudan center på NIAS blev } \\
\text { aktivt. Aftale med Yonsei } \\
\text { universitet i Seoul om samarbejde } \\
\text { indenfor forskning. Fudan og } \\
\text { Yonsei er med i NIAS platformen } \\
\text { Asien og Arktis. European } \\
\text { Alliance for Asian Studies gen- } \\
\text { etableret, enighed om fælles PhD } \\
\text { kurser. }\end{array}$ \\
\hline
\end{tabular}

\section{2-3184 Nordisk vulkanologisk institut (NORDVULK)}

Programlignende aktiviteter

\begin{tabular}{|l|c|c|c|c|c|} 
Valuta & Budget 2016 & Budget 2015 & Budget 2014 & Disp./bud. 14 & Budget disp. af \\
\hline DKK & 4.344 .000 & 4.344 .000 & 4.280 .000 & $98 \%$ & Styret i \\
& & & & & NORDVULK
\end{tabular}

Formål Nordisk Vulkanologisk Center (NordVulk) har til formål at fremstå som en fælles Nordisk kompetence indenfor forskning i vulkanologiske processer og relaterede emner, herunder klimatiske påvirkninger samt råstof dannelser.

Forvaltnings- Islands Universitet organ 


\begin{tabular}{|c|c|c|}
\hline \multicolumn{3}{|l|}{ Mål og resultatopfølgning } \\
\hline 2016 - Mål & 2015 - Mål & 2014 - Opnåede resultater \\
\hline $\begin{array}{l}\text { At forstærke det nordiske } \\
\text { samarbejde indenfor } \\
\text { geologi/geofysik } \\
\text { At agere vært for minimum } 5 \\
\text { stipendiater indenfor emnet } \\
\text { vulkanologiske processer. } \\
\text { At publicere minimum } 15 \text { peer- } \\
\text { reviewed videnskabelige artikler i } \\
\text { internationale tidsskrifter. } \\
\text { At afholde en geologisk } \\
\text { sommerskole på PhD niveau } \\
\text { At agere vært for Nordiske } \\
\text { forskere på forskningsorlov }\end{array}$ & $\begin{array}{l}\text { Lede eller deltage i internationale } \\
\text { forskningsprojekter indenfor } \\
\text { geologi/geofysik. } \\
\text { Agere som vært for minimum 4-5 } \\
\text { unge nordiske forskere og/eller } \\
\text { forskningsstuderende indenfor } \\
\text { emnet vulkanologiske processer. } \\
\text { Publicere minimum } 10 \text { peer- } \\
\text { reviewed videnskabelige artikler i } \\
\text { internationale tidsskrifter. } \\
\text { Afholde en geologisk } \\
\text { sommerskole på PhD niveau, } \\
\text { forudsat at eksterne bevillinger } \\
\text { opnås. }\end{array}$ & $\begin{array}{l}\text { Ledte ”FutureVolc” projektet } \\
\text { sponsorereret af EU } \\
\text { Deltog i de europæiske } \\
\text { uddannelsesnetværk NemoH og } \\
\text { MeMoVolc } \\
\text { Var vært for nordiske fellows; } 3 \text { i } \\
\text { PhD forløb og } 5 \text { Post Docs } \\
\text { Publicerede19 peer-reviewed } \\
\text { videnskabelige artikler i } \\
\text { internationale tidsskrifter } \\
\text { Publicerede } 4 \text { populær } \\
\text { videnskabelige artikler } \\
\text { Afholdt en PhD sommerskole } \\
\text { sponsoreret af NordForsk og } \\
\text { MeMoVolc }\end{array}$ \\
\hline
\end{tabular}

\section{2-3185 Nordisk Samisk Institut (NSI)}

Programlignende aktiviteter
\begin{tabular}{|l|c|c|c|c|c|} 
Valuta & Budget 2016 & Budget 2015 & Budget 2014 & Disp./bud. 14 & Budget disp. af \\
\hline DKK & 1.642 .000 & 1.642 .000 & 1.618 .000 & $100 \%$ & $\begin{array}{c}\text { Styret for Samisk } \\
\text { Høgskole }\end{array}$
\end{tabular}

Formål Samisk høgskoles forskningsprogram "Samisk forskning for det samiske samfunn II", med kontraktsperiode 2014-2016, har til formål å framskaffe forskningsresultater av høy kvalitet som er til nytte for det samiske samfunnet og urfolkssamfunn i øvrig. Kunnskapsutviklingen skal resultere i publisering, kapasitetsoppbygging og rekruttering innenfor disiplinene rettshistorie, utdanningsforskning, etikk, statistikk, språkforskning, tradisjonell kunnskap og tradisjonelle næringer. Samisk som vitenskapsspråk skal styrkes.

Forvaltnings- Sámi allaskuvla Sámi University College (Samisk høgskole) organ

\begin{tabular}{|c|c|c|}
\hline \multicolumn{3}{|l|}{ Mål og resultatopfølgning } \\
\hline 2016 - Mål & 2015 - Mål & 2014 - Opnåede resultater \\
\hline $\begin{array}{l}\text { Videreføring av } \\
\text { forskningsprosjekter innenfor } \\
\text { de prioriterte fagdisiplinene. } \\
\text { Gjennomføre } 2 \text { forprosjekter } \\
\text { med formålet å utvikle phd- } \\
\text { prosjekter. } \\
\text { Arrangere } 1 \text { forsknings- } \\
\text { konferanse, samt Forsknings- } \\
\text { dagene. }\end{array}$ & $\begin{array}{l}\text { Videreføring av } \\
\text { forskningsprosjekter innenfor de } \\
\text { prioriterte fagdisiplinene. } \\
\text { Gjennomføre } 2 \text { forprosjekter } \\
\text { med formålet a utvikle PhD- } \\
\text { prosjekter. } \\
\text { Arrangere } 1 \text { forsknings- } \\
\text { konferanse, samt Forsknings- } \\
\text { dagene. }\end{array}$ & $\begin{array}{l}\text { SH har i løpet av } 2014 \text { finansiert } 6 \\
\text { forskningsprosjekter innenfor } \\
\text { fagdisipliner statsvitenskap, } \\
\text { utdanningsforskning, lingvistikk, } \\
\text { språkpolitikk, litteraturvitenskap og } \\
\text { duodji. } \\
\text { SH har gjennomført to } \\
\text { forprosjekter, med formålet å } \\
\text { utvikle PhD-prosjekter. } \\
\text { SH har gjennomført en forsk- }\end{array}$ \\
\hline
\end{tabular}




\begin{tabular}{|l|l|l|}
\hline $\begin{array}{l}\text { Publisere 2 Dieđut-bøker og } 2 \\
\text { nummer av Sámi dieđalaš } \\
\text { áigečála. }\end{array}$ & $\begin{array}{l}\text { Publisere 2 Dieđut-bøker og } 2 \\
\text { nummer av Sámi dieđalaš } \\
\text { áigečála. }\end{array}$ & $\begin{array}{l}\text { ningskonferanse innen } \\
\text { litteraturvitenskap og arrangert } \\
\text { Forskningsdagene for å formidle } \\
\text { resultatene fra våre forsknings- } \\
\text { prosjekter. }\end{array}$ \\
& $\begin{array}{l}\text { SH har i løpet av 2014 publisert 4 } \\
\text { bøker i serien Dieđut, og arbeidet } \\
\text { med 2 nummer av Sámi dieđalaš } \\
\text { áigećála, som publiseres i 2015. }\end{array}$ \\
\hline
\end{tabular}




\section{Social- og Helsepolitik}

\section{Generel indledning}

Formål og Ministerrådet for Social- og Helsepolitik (MR-S) arbejder for at landene opnår en Fakta merværdi ved, at udvalgte opgaver analyseres og/eller løses på nordisk plan for at øge nordisk kompetence og konkurrencekraft. Samarbejdet koncentrerer sig om udvikling og bæredygtigheden af det nordiske velfærdssamfund, og må ses i et europæisk/globalt perspektiv.

Strategiske målsætninger 2016

Ministerrådets resultater i 2014
Det social- og sundhedspolitiske samarbejde bygger på en strategi som gælder 2013 og frem. Der er tale om et overordnet politisk dokument, som komplementeres af formandskabets prioriteringer, og det der bliver besluttet af MR-S. De strategiske tiltag er i hovedtræk koncentreret om fire mål der skal bidrage til at styrke en bæredygtig velfærd og sundhed i Norden. Det handler blandt andet om at sikre social tryghed i Norden på et arbejdsmarked under stadig forandring og en målrettet indsats for forebyggelse, f.eks. fokus på at forebygge livsstilssygdomme og at fremme psykisk sundhed. Desuden samarbejder MR-S om at styrke kvaliteten og sikkerheden i socialog sundhedsvæsenet og at fremme innovation via erfaringsudveksling og forskning indenfor sundheds-, omsorgs- og velfærdstjenesterne.

Strategien suppleres af en handlingsplan, som er en oversigt der konkret beskriver de projekter og initiativer der løber i 2016. Strategien og handlingsplanen er offentliggjort på www.norden.org

Landene ønsker at udvide og styrke samarbejdet på sundhedsområdet og vil i 2016 fortsætte diskussionen og opfølgningen af Bo Könbergs rapport Det framtida nordiska hälsosamarbetet. Se i øvrigt budgetpost 3-4311.

I 2016 videreføres arbejdet med at opsamle og formidle de væsentligste resultater af det tværsektorielle program Holdbar Nordisk Velfcerd, blandt andet via opfølgningen af rapporten Det framtida nordiska hälsosamarbetet. Se i øvrigt budgetpost 1-8210.

Resultatberetningen for MR-S beskriver her de resultater som ligger ud over resultaterne beskrevet under de enkelte budgetposter. Der kan være tale om tværsektorielle resultater og aktiviteter der finansieres af andre sektorer, så som programmet Holdbar Nordisk Velfcerd og samarbejdet med nabolandene.

I regi af programmet Holdbar Nordisk Velfcerd er der arbejdet med en række projekter på MR-S`s område videreført i 2014, blandt andet inden velfærdsteknologi, socialt entreprenørskab, samarbejde indenfor velfærdsprofessioner, forskning om social ulighed i sundhed og velfærd samt kliniske multicenterstudier. Læs mere om de enkelte projekter og konkrete resultater i programmet i rapporteringen til statsministrene og på hjemmesiden www.norden.org/valfard.

Bo Könberg, har i opdrag fra MR-S og fra Generalsekretæren gennem 2013 og første del af 2014 foretaget en uafhængig udredning, der giver bud på, hvor og hvordan det nordiske samarbejde på sundhedsområdet kan udvikles og styrkes over de næste fem til ti år. Könbergs udredning resulterede i en rapport med fjorten konkrete anbefalinger Det framtida nordiska hälsosamarbetet. I 2014 drøftede MR-S rapporten i sin helhed og besluttede at arbejde videre med fem af anbefalingerne: højt specialiserede behandlinger (förslag 2), sjældne diagnoser (förslag 3), psykiatri (förslag 10), helseberedskab (förslag 11) og tjenestemandsudveksling (förslag 13). MR-S besluttede også at diskutere forslaget om antibiotikaresistens (förslag 1) med ministerkollegaer, som er ansvarlige 
for udenrigs- og udviklingsområdet. MR-S besluttede også at fortsætte diskussionen om rapportens resterende forslag.

MR-S har i 2014 bidraget til samarbejdet med Nordvestrusland og Estland, Letland og Litauen i forbindelse med Nordisk Ministerråds program mod menneskehandel.

Programmet blev i 2014 afsluttet med konferencen "Human Trafficking Today - Our Joint Baltic Sea Challenge”, som blev afholdt i Skt. Petersborg. Konferencen satte fokus på menneskehandel i Østersøområdet, og på det arbejde som gennemføres i regionen.

MR-S besluttede i sommeren 2013 at nedlægge Nordic School of Public Health NHV med virkning fra den 1 . januar 2015. NHV's bestyrelse har ansvaret for afviklingen af skolen. I 2014 har NHV's virksomhed været meget præget af afviklingen og den situation at NHV måtte parallelt med afviklingen fortsætte med uddannelses- og forskningsvirksomhed. NHV's uddannelses- og forskningsvirksomhed sluttede formelt den 31. december 2014.

MR-S besluttede i 2013, at opretholde højt niveau i samarbejdet inden for området folkesundhed. Landene er i gang med en drøftelse om prioriteringer og niveau for det fremtidige samarbejde, bl.a. i lyset af afviklingen af NHV.

\begin{tabular}{|c|c|c|c|c|c|}
\hline & \multirow{2}{*}{$\begin{array}{r}\text { Budget } \\
2016\end{array}$} & \multirow{2}{*}{$\begin{array}{r}\text { Budget } \\
2015\end{array}$} & \multicolumn{2}{|c|}{ Difference } \\
\hline & & & & $+/-$ & $\%$ \\
\hline \multicolumn{2}{|c|}{ MR-S (TDKK) } & 38.956 & 38.956 & $\overline{0}$ & $0,0 \%$ \\
\hline & Projektmedel & 18.621 & 18.621 & 0 & $0,0 \%$ \\
\hline $3-4310$ & Projekmedel - Social- och hälsovårdspolitik & 4.568 & 4.568 & 0 & $0,0 \%$ \\
\hline 3-4311 & $\begin{array}{l}\text { Nordisk helsesamarbejde - opfølgning af Bo Könbergs } \\
\text { rapport }\end{array}$ & 1.243 & 1.243 & 0 & - \\
\hline $3-4320$ & Rådet för nordiskt samarbete om funktionshinder & 1.123 & 1.123 & 0 & $0,0 \%$ \\
\hline $3-4340$ & Nomesko og Nososko & 1.892 & 1.892 & 0 & $0,0 \%$ \\
\hline \multirow[t]{2}{*}{ 3-4382 } & NIOM AS - Nordisk institutt for Odontologiske Materialer & 9.795 & 9.795 & 0 & $0,0 \%$ \\
\hline & Institutioner & 20.335 & 20.335 & 0 & $0,0 \%$ \\
\hline $3-4380$ & Nordens Välfärdcenter & 20.335 & 20.335 & 0 & $0,0 \%$ \\
\hline \multicolumn{2}{|c|}{ Opdelt på kategorier } & 38.956 & 38.956 & $100 \%$ & $100 \%$ \\
\hline & Projektmidler & 8.826 & 8.826 & $22,7 \%$ & $22,7 \%$ \\
\hline & Programlignende aktiviteter & 9.795 & 9.795 & $25,1 \%$ & $25,1 \%$ \\
\hline & Institutioner & 20.335 & 20.335 & $52,2 \%$ & $52,2 \%$ \\
\hline
\end{tabular}

\section{Projektmedel}

3-4310 Projektmidler - Social- och hälsvårdspolitik

Projektmidler
\begin{tabular}{|l|c|c|c|c|c|} 
Valuta & Budget 2016 & Budget 2015 & Budget 2014 & Disp./bud. 14 & Budget disp. af \\
\hline DKK & 4.568 .000 & 4.568 .000 & 5.725 .000 & $85 \%$ & MR-S/EK-S
\end{tabular}

Formål Projektmidlerne koncentreres til færre områder og større projekter og er et vigtigt virkemiddel til at udmønte MR-S politiske prioriteringer. Det er et krav at mindst tre nordiske lande deltager i projekterne. 


\begin{tabular}{|c|c|c|}
\hline \multicolumn{3}{|l|}{ Mål og resultatopfølgning } \\
\hline 2016 - Mål & 2015 - Mål & 2014 - Opnåede resultater \\
\hline $\begin{array}{l}\text { Ny nordisk videreuddannelse, } \\
\text { smitsomme sygdomme og } \\
\text { hospitalshygiejne: } \\
\text { Målet er at etablere den } \\
\text { videregående uddannelse i } 2016 . \\
\text { EK-S har i } 2016 \text { afsat 2,4 MDKK } \\
\text { til etableringen af uddannelsen. } \\
\text { Aktiviteter under det finske } \\
\text { formandskab:Sikre opfølgning af } \\
\text { forslag 5, 6, } 9 \text { og } 11 \text { i rapporten } \\
\text { Det Framtida nordiska } \\
\text { hälsosamarbetet. EK-S } \\
\text { godkendte at afsætte } 1 \text { MDKK til } \\
\text { disse aktiviteter i } 2016 \text { hvor den } \\
\text { største satsning bliver konference } \\
\text { til 550.000 DKK om } \\
\text { videreudvikling af } \\
\text { folkesundhedssamarbejdet og den } \\
\text { nordiske velfærdsmodel. } \\
\text { Initiativer vedrørende } \\
\text { menneskehandel: } \\
\text { MR-S indgår i NMR } \\
\text { tværsektorielle program mod } \\
\text { menneskehandel. Programmet } \\
\text { har til formål at bidrage til } \\
\text { landenes arbejde med } \\
\text { forebyggelse af menneskehandel, } \\
\text { retsforfølgelse af } \\
\text { menneskehandlere og beskyttelse } \\
\text { af ofre for menneskehandel. } \\
\text { Programmet omfatter bidrag til } \\
\text { styrkelse af den faglige og } \\
\text { organisatoriske kapacitet hos } \\
\text { relevante aktører, blandt andet } \\
\text { gennem udveksling af viden og } \\
\text { erfaringer samt gennem } \\
\text { implementering af guidelines og } \\
\text { virksomme løsninger. } \\
\text { Programmet skal desuden styrke } \\
\text { samarbejdet mellem specialister, } \\
\text { der arbejder med } \\
\text { menneskehandel i daglig praksis } \\
\text { og på tværs af aktører. }\end{array}$ & $\begin{array}{l}\text { Inklusion af udsatte unge i } \\
\text { arbejdsliv og uddannelse: } \\
\text { Delrapporteringer af gennemgang } \\
\text { af forskning om } \\
\text { førtidspensionering af unge. } \\
\text { Delrapporteringer af gennemgang } \\
\text { af forskning om psykisk sårbare } \\
\text { unge inden for } \\
\text { uddannelsessektoren samt } \\
\text { overgangen fra skole til } \\
\text { arbejdsliv. Resultaterne fra } \\
\text { forskningsgennemgangene } \\
\text { kommunikeres løbende til } \\
\text { relevante aktører i Norden, } \\
\text { herunder til nationale } \\
\text { myndigheder, forskere, praktikere } \\
\text { mv. } \\
\text { Nordisk Konvention om social } \\
\text { bistand og sociale tjenester: } \\
\text { Iværksættelse af anbefalingerne } \\
\text { fra analysen af } \\
\text { bistandskonventionen. } \\
\text { Samarbejde om eHelse: } \\
\text { En projektplan skal udarbejdes } \\
\text { om nordiske e-recepter. } \\
\text { Slutrapporten for samarbejdet om } \\
\text { nordisk eHelse præsenteres ved } \\
\text { MR-S mødet i 2015. }\end{array}$ & $\begin{array}{l}\text { Inklusion af udsatte unge i } \\
\text { arbejdsliv og uddannelse: } \\
\text { Projektet har i } 2014 \text { fokuseret på } \\
\text { at forberede projektets } \\
\text { hovedleverancer, som vil falde i } \\
\text { 2015, herunder blandt andet } \\
\text { policyrettede, komparative } \\
\text { analyser af unges psykiske } \\
\text { sundhed i Norden og de nordiske } \\
\text { landes socialforsikringssystemer. } \\
\text { Nordisk Konvention om social } \\
\text { bistand og sociale tjenester: } \\
\text { Analysen af konventionens } \\
\text { anvendelsesområde blev ikke } \\
\text { færdiggjort i 2014. EK-S skal i } \\
\text { 2015 drøfte analysen og behovet } \\
\text { for revision af konventionen. } \\
\text { Samarbejde om eHelse: } \\
\text { eHälsogruppen och de tre } \\
\text { undergrupper: Forskarnätverket, } \\
\text { Juristnätverket och Nätverket för } \\
\text { nordiskt eRecept har fortsatt } \\
\text { arbetet med att ta fram } \\
\text { gemensamma nordiska e- } \\
\text { hälsoindikatorer och har kartlagt } \\
\text { de juridiska och tekniska } \\
\text { förutsättningarna för nordiskt e- } \\
\text { recept. } \\
\text { Det framtida nordiska } \\
\text { hälsosamarbetet (Könberg- } \\
\text { rapporten): } \\
\text { Rapporten og dens konkrete } \\
\text { anbefalinger blev overleveret den } \\
\text { 11. juni } 2014 \text { til den islandske } \\
\text { sundhedsminister. MR-S } \\
\text { drøftede rapporten i sin helhed } \\
\text { den } 16 . \text { oktober } 2014 \text {. MR-S } \\
\text { besluttede at arbejde videre med } \\
\text { fem af anbefalingerne (forslag } 2 \text {, } \\
\text { 3, 10, 11 og 13) og drøfte } \\
\text { anbefaling om } \\
\text { antibiotikaresistens (forslag } 1 \text { ) } \\
\text { med ministerkollegaer, som er } \\
\text { ansvarlige for udenrigs- og } \\
\text { udviklingsområdet. }\end{array}$ \\
\hline
\end{tabular}




\section{3-4311 Nordisk helsesamarbejde - opfølgning af Bo Könbergs rapport}

Projektmidler
\begin{tabular}{|l|c|c|c|c|c|} 
Valuta & Budget 2016 & Budget 2015 & Budget 2014 & Disp./bud. 14 & Budget disp. af \\
\hline DKK & 1.243 .000 & 1.243 .000 & 0 & $100 \%$ & MR-S/EK-S
\end{tabular}

Formål Rapporten Det framtida nordiska hälsosamarbetet har en række anbefalinger til det fremtid nordiske sundhedssamarbejde. MR-S vil drøfte og beslutte hvordan og i hvilket omfang rapportens anbefalinger skal iværksættes. Til at igangsætte og virkeliggøre dette nye samarbejde er der afsat midler under denne budgetpost.

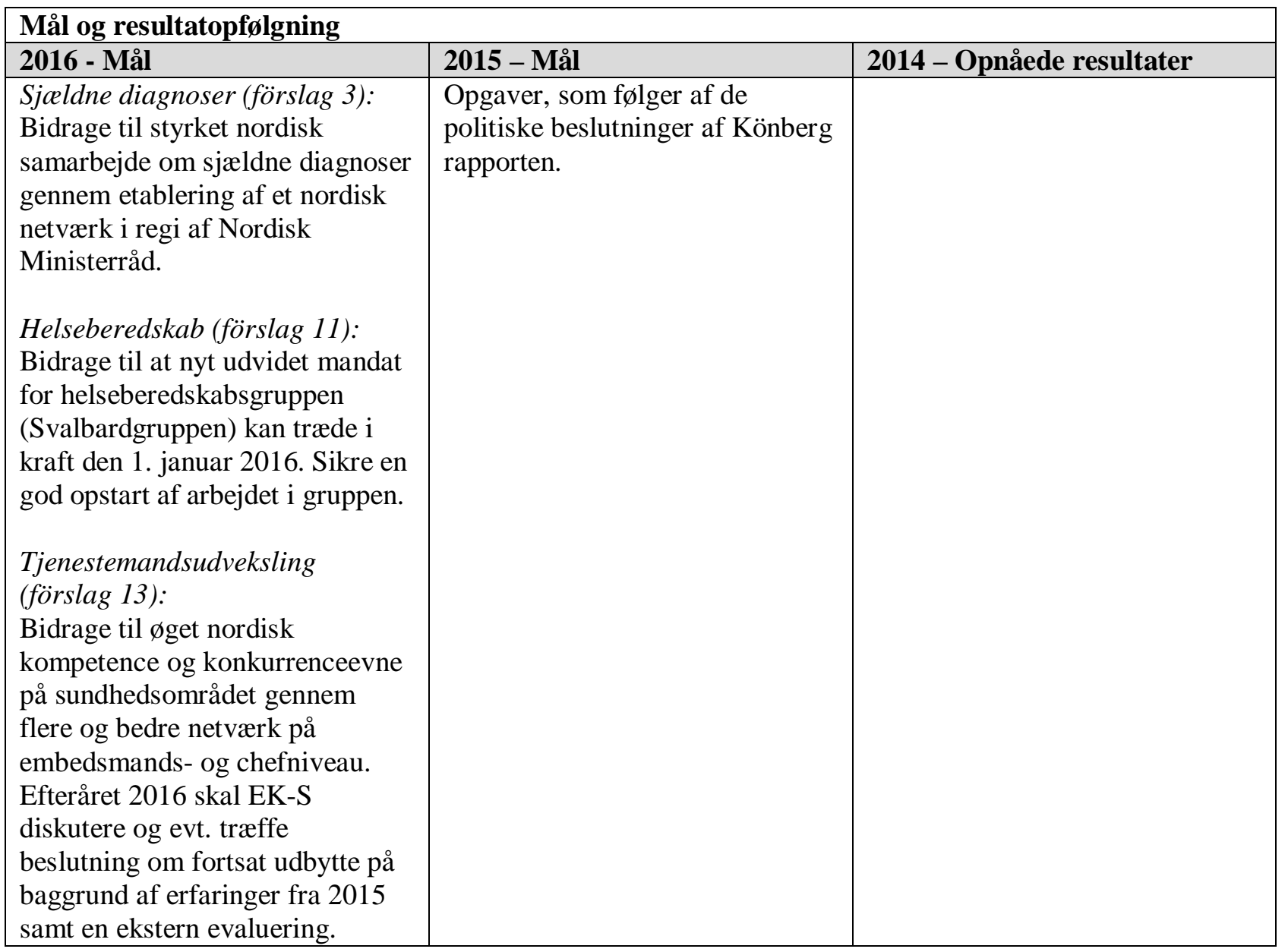

3-4320 Rådet för nordiskt samarbete om funktionshinder

Projektmidler
\begin{tabular}{|l|c|c|c|c|c|} 
Valuta & Budget 2016 & Budget 2015 & Budget 2014 & Disp./bud. 14 & Budget disp. af \\
\hline DKK & 1.123 .000 & 1.123 .000 & 1.106 .000 & $100 \%$ & NVC
\end{tabular}

Formål Rådet för nordiskt samarbete om funktionshinder (härefter Rådet) är förankrat i MR-S, men är ett rådgivande organ för hela Nordiska ministerrådet. Rådet ska fungera som plattform för kunskapsdelning och informationsutbyte mellan sakkunniga i de nordiska länderna och självstyrande områdena.

Rådet får uppdrag från Nordiska Ministerrådet men har rätt att på eget initiativ lyfta 
frågor och uppgifter som Rådet finner viktiga i det nordiska samarbetet på funktionshinderområdet.

Rådet består av sexton experter på funktionshindersfrågor. Hälften är utsedda av regeringar c hälften av funktionshindersorganisationernas paraplyorganisationer eller liknande i respektiv nordiskt land och självstyrande område.

http://www.nordicwelfare.org/Om-oss/Funktionshinderradet/

I överensstämmelse med den av MR-S antagna strategin för social- och hälsoområdet för perioden 2013 och framåt har de nedan nämnda målen blivit fastlagda.

Forvaltnings- Nordens Velfærdscenter (NVC)

organ

\begin{tabular}{|c|c|c|}
\hline \multicolumn{3}{|l|}{ Mål og resultatopfølgning } \\
\hline 2016 - Mål & 2015 - Mål & 2014 - Opnåede resultater \\
\hline $\begin{array}{l}\text { Funktionshinderrådet fortsätter } \\
\text { följa upp genomförandet av } \\
\text { uppgifter och mål i } \\
\text { handlingsplanen och Rådet } \\
\text { medverkar i projektet } \\
\text { Funktionshindersperspektiv, kön } \\
\text { och mångfald som finansieras } \\
\text { med } 1 \text { MDKK i } 2014 \text { av den } \\
\text { tvärsektoriella insatsen Hållbar } \\
\text { Utveckling, budgetpost } 0460 . \\
\text { Rådet görs mer känt i } \\
\text { nyckelmiljöer på nordisk och } \\
\text { nationell nivå och Rådet } \\
\text { tydliggör } \\
\text { funktionshindersperspektiv i } \\
\text { relevanta delar av det nordiska } \\
\text { samarbetet. }\end{array}$ & $\begin{array}{l}\text { Rådet fortsätter arbetet med at } \\
\text { följa upp genomförandet av } \\
\text { uppgifter och mål i } \\
\text { handlingsplanen. } \\
\text { Rådets arbete ska utvärderas och } \\
\text { eventuella behov till förändringar } \\
\text { för mandatet för Rådet kommer } \\
\text { att kartläggas. }\end{array}$ & $\begin{array}{l}\text { Rådet gav inspel till } \\
\text { handlingsplanen för } \\
\text { funktionshinderssamarbetet och } \\
\text { till utredningen om eventuell } \\
\text { revidering av den nordiska } \\
\text { biståndskonventionen. Rådet } \\
\text { avslutade arbetet om } \\
\text { inkluderande kultur och medier } \\
\text { samt trendrapporten och samlade } \\
\text { in kunskap om våld samt } \\
\text { genomförde ett antal } \\
\text { informationsinsatser och möten } \\
\text { med nordiska parlamentariker. }\end{array}$ \\
\hline
\end{tabular}

$\underline{3-4340 \text { Nomesko og Nososko }}$

\begin{tabular}{|l|c|c|c|c|c|} 
Projektmidler & & & \\
Valuta & Budget 2016 & Budget 2015 & Budget 2014 & Disp./bud. 14 & Budget disp. af \\
\hline DKK & 1.892 .000 & 1.892 .000 & 1.864 .000 & $100 \%$ & Statens Serum \\
& & & & & Institut, Danmark
\end{tabular}

Formål Bidraget til Nordisk Medicinalstatistisk Komité (NOMESKO) og Nordisk Socialstatistisk Komité (NOSOSKO) har til formål at sikre, at nordisk statistik på social- og sundhedsområdet er sammenligneligt mellem landene, at indsamle nordisk statistik på området, og gøre denne bredt tilgængelig via publikationer samt databaser på hjemmesiden www.nowbase.org Desuden skal man sikre nordisk koordinering internationalt i relevante statistiksammenhænge. Statistikmaterialet er et værktøj som bliver anvendt til at træffe beslutninger på andre områder indenfor Nordisk Ministerråd.

I overensstemmelse med den af MR-S besluttede strategi at sikre og udbrede nordisk statistik er følgende mål fastlagt for 2016:

Forvaltnings- Statens Serum Institut, Danmark organ 


\begin{tabular}{|c|c|c|}
\hline \multicolumn{3}{|l|}{ Mål og resultatopfølgning } \\
\hline 2016 - Mål & 2015 - Mål & 2014 - Opnåede resultater \\
\hline $\begin{array}{l}\text { Health Statistics for the Nordic } \\
\text { Countries og Social Protection in } \\
\text { the Nordic Countries: } \\
\text { Udgivelse af årlige publikationer } \\
\text { med sammenlignelig nordisk } \\
\text { statistik. } \\
\text { Forstudie om patientbevcegelser } \text { i } \\
\text { Norden: } \\
\text { Forstudie til projekt om } \\
\text { patientbevægelser i Norden i } \\
\text { samarbejde med Finlands } \\
\text { formandskab. } \\
\text { Formidling: } \\
\text { Implementering af ny } \\
\text { formidlingsstrategi, herunder } \\
\text { udvikling af hjemmeside. }\end{array}$ & $\begin{array}{l}\text { Helsestatistik for de nordiske } \\
\text { lande og Social tryghed i de } \\
\text { nordiske lande: } \\
\text { En publikation der bliver udgivet } \\
\text { på dansk og på engelsk. } \\
\text { Projekt om velfcerdsindikatorer: } \\
\text { Opfølgning på projektet. } \\
\text { Hjemmeside: } \\
\text { Videreudvikling af den fælles } \\
\text { hjemmeside. } \\
\text { Projekter: } \\
\text { Gennemføres til udvikling af } \\
\text { sammenlignelig statistik eller } \\
\text { belysning af specifikke social- } \\
\text { eller sundhedspolitiske emner. }\end{array}$ & $\begin{array}{l}\text { Helsestatistik for de nordiske } \\
\text { lande og Social tryghed i de } \\
\text { nordiske lande: } \\
\text { Udgivet på dansk og på engelsk. } \\
\text { Temapublikationer: } \\
\text { Projekt om Velferdsindikatorer: } \\
\text { Opstart af projekt i samarbejde } \\
\text { med det islandske formandskab. } \\
\text { Projekter om Social ulighed i } \\
\text { dødelighed, Sygefravcer og } \\
\text { Mikrosimuleringsmodeller i } \\
\text { Norden: } \\
\text { Projekterne afsluttes i } 2015 . \\
\text { Projekt Fldres Helse: } \\
\text { Udskudt til 2015. } \\
\text { Formidling: } \\
\text { Arbejdsgruppe for ny } \\
\text { formidlingsstrategi. Nyhedsbrev } \\
\text { etableret. } \\
\text { Intern struktur: } \\
\text { Fælles møder for komiteerne } \\
\text { NOMESKO/NOSOSKO. }\end{array}$ \\
\hline
\end{tabular}

Målene for budget 2016 søges realiseret hovedsageligt via indsamling af sammenlignelige data og løbende revidering og udvikling af de årlige statistikpublikationer. Der skal gennemføres projekter til statistikudvikling eller belysning af specielle områder, publicering af projektresultater i specialpublikationer, afholdelse af seminarer, samt kommunikation af alt ovenstående gennem egen hjemmeside og database.

3-4382 NIOM A/S - Nordisk Institutt for Odontologiske Materialer

\section{Programlignende aktiviteter}

\begin{tabular}{|l|c|c|c|c|c|} 
Valuta & Budget 2016 & Budget 2015 & Budget 2014 & Disp./bud. 14 & Budget disp. af \\
\hline DKK & 9.795 .000 & 9.795 .000 & 10.456 .000 & $100 \%$ & NIOM AS
\end{tabular}

Formål $\quad$ NIOM A/S har til formål å sikre at medisintekniske produkter som benyttes innen tannpleien i Norden, oppfyller de helsemessige og tekniske krav som kan stilles med hensyn til utviklingen innen området. NIOM A/S forsknings- og informasjonsvirksomhet skal baseres på vitenskapelig grunn og være praktisk anvendelig i klinisk virksomhet for å bidra til at pasienter i nordiske land får sikre og velfungerende biomaterialer. NIOM A/S skal videreutvikle det nordiske forskningssamarbeidet gjennom økt fokus på kliniske problemstillinger. Se NIOM A/S hjemmeside på www.niom.no

I overensstemmelse med den av MR-S besluttede strategi for sosial- og helseområdet 2013 og frem er de nedenfor nevnte mål fastlagt for 2016: 
Forvaltnings- NIOM A/S (Nordisk Institut for Odontologiske Materialer), Oslo. organ

\begin{tabular}{|c|c|c|}
\hline \multicolumn{3}{|l|}{ Mål og resultatopfølgning } \\
\hline 2016 & 015 - Mål & 2014 - Opnåede resultater \\
\hline $\begin{array}{l}\text { Forskning: } \\
\text { Fremskaffe informasjon om } \\
\text { materialenes biokompatibilitet og } \\
\text { funksjonelle gjenskaper gjennom } \\
\text { laboratorieundersøkelser og } \\
\text { kliniske pasientnære studier. } \\
\text { Gjennomføre og koordinere } \\
\text { tverrfaglige og samnordiske } \\
\text { prosjekter. } \\
\text { Synlighet og formidling: } \\
\text { Være førstevalg når myndigheter } \\
\text { profesjon og pasienter ønsker } \\
\text { uavhengig informasjon. } \\
\text { Publisere klinisk relevant } \\
\text { informasjon om materialer og } \\
\text { metoder basert på egne og andres } \\
\text { forskningsresultater. } \\
\text { Videreutvikle og vedlikeholde } \\
\text { nettbasert informasjonsportal. } \\
\text { Avholde etter- og } \\
\text { videreutdanningskurs og } \\
\text { seminarer for tannleger. }\end{array}$ & $\begin{array}{l}\text { Forskning: } \\
\text { Genomförande och koordination } \\
\text { av tvärvetenskapliga och } \\
\text { samnordiska forskningsprojekt. } \\
\text { Aktivt samarbete med minst en } \\
\text { institution från vart nordiskt land } \\
\text { i ett nordiskt nätverk inom } \\
\text { området dentala biomaterial. } \\
\text { Fremskaffe ny kunnskap om } \\
\text { kliniske og biologiske egenskaper } \\
\text { til dentale biomaterialer som } \\
\text { polymerer, keramer og metaller. } \\
\text { Synlighet og formidling: } \\
\text { NIOM A/S skall vara } \\
\text { förstahandsvalet när } \\
\text { helsemyndigheter, profesjon og } \\
\text { pasienter ønsker vetenskapligt } \\
\text { baserade svar på frågor om } \\
\text { dentala biomaterial: } \\
\text { Videreutvikle og vedlikeholde } \\
\text { nettbasert informasjonsportal. } \\
\text { Publisere klinisk relevant } \\
\text { informasjon om materialer og } \\
\text { metoder basert på egne og andres } \\
\text { forskningsresultater. Avholde } \\
\text { etter- og videreutdanningskurs og } \\
\text { seminarer for tannleger }\end{array}$ & $\begin{array}{l}\text { Forskning: } \\
\text { Seks av NIOMs } \\
\text { forskningsprosjekter er samarbeid } \\
\text { med institusjoner i Sverige, } \\
\text { Finland, Danmark, Island og } \\
\text { Norge. } \\
\text { Åtte gjesteforskere ble tilbudt } \\
\text { arbeidsplass ved NIOM i } 2014 \text { i } \\
\text { til sammen } 24 \text { mndr, derav fem } \\
\text { fra universiteter og høyskoler i } \\
\text { Finland, Sverige og Island. } \\
\text { NIOMs forskere har veiledet dr. } \\
\text { gradskandidater, masterstudenter } \\
\text { og bachelorstudenter. } \\
\text { Synlighet og formidling: } \\
\text { Nordiske tannleger gjøres kjent } \\
\text { med NIOMs forskningsresultater } \\
\text { og råd gjennom kurs og foredrag, } \\
\text { publisering i nordiske } \\
\text { tannlegetidsskrifter og via } \\
\text { NIOMs hjemmeside. } \\
\text { Nordiske tannleger mottar et } \\
\text { månedlig nyhetsbrev fra NIOM. } \\
\text { NIOM besvarer også en rekke } \\
\text { henvendelser fra nordiske } \\
\text { tannleger når det gjelder } \\
\text { materialbruk og -valg. }\end{array}$ \\
\hline
\end{tabular}

Målene søges realiseret hovedsageligt via nordiske gjesteforskeraktivitet, nordiske samarbeidsprosjekter, forskningsaktivitet, metodeseminarer, utadrettete aktiviteter, kurs, fortatte nyhetsbrev og publikasjoner og arbeid på hjemmesider.

\section{Institutioner}

$\underline{3-4380 \text { Nordens Välfärdscenter (NVC) }}$

Institution
\begin{tabular}{|l|c|c|c|c|c|} 
Valuta & Budget 2016 & Budget 2015 & Budget 2014 & NMR fin. 14 & Budget disp. af \\
\hline SEK & 24.500 .000 & 24.500 .000 & 24.301 .000 & $86 \%$ & Institutionen \\
\hline Modsv. DKK & 20.335 .000 & 20.335 .000 & 21.142 .000 & &
\end{tabular}

Nordens Välfärdscenter (NVC) er også forvaltningsorgan for en del af budgetpost 1-1012, Norden i Fokus.

NVC er sekretariatet for Rådet för nordiskt samarbete om funktionshinder, budgetpost 3-4320. 
Formål

Nordens Välfärdscenter (NVC) är Nordiska ministerrådets huvudorgan för att främja utvecklingen inom det socialpolitiska området i Norden och dess närområde. NVC ska genom utbildning, information, främjande av forskningssamarbete och spridning av forskningsresultat, utvecklingsarbete, nätverksbyggande och internationellt arbete m.m. höja kvaliteten inom det socialpolitiska området i Norden och dess närområde och geno dessa insatser bidra till att utveckla den nordiska välfärdsmodellen. Se NVC:s hemsida ] www.nordicwelfare.se

Förutom den grundläggande budget kan NVC ta på sig uppgifter som har särskild finansiering för genomförandet av projekt och aktiviteter.

I överensstämmelse med den av MR-S antagna strategin för social- och hälsoområdet för perioden 2013 och framåt har de nedan nämnda målen blivit fastlagda för 2016.

Kontraktperiode NVCs nuvarande kontrakt löper under perioden 2015-2017 og -status

\begin{tabular}{|c|c|c|}
\hline \\
\hline 2016 & Iål & tater \\
\hline $\begin{array}{l}\text { Av överordnade mål för } \\
\text { institutionens verksamhet i } 2016 \\
\text { kan nämnas: } \\
\text { NVC genomför initiativ som ska } \\
\text { stödja det nordiska samarbetet } \\
\text { och som ska bidra till ländernas } \\
\text { arbete med kvalitet på } \\
\text { välfärdsområdet vid att fungera } \\
\text { som ett kunskapscenter, } \\
\text { informera, ta initiativ till } \\
\text { lämpliga sätt att stärka och sprida } \\
\text { kunskap inom välfärdsområdet } \\
\text { samt genom att förmedla } \\
\text { kontakter mellan relevanta } \\
\text { aktörer i länderna. } \\
\text { NVC följer upp handlingsplan för } \\
\text { nordiskt samarbete på } \\
\text { funktionshinderområdet. } \\
\text { NVC bidrar till at stärka } \\
\text { ländernas insats för personer med } \\
\text { dövblindhet genom at erbjuda } \\
\text { kompetensutveckling av } \\
\text { personal. } \\
\text { NVC bidrar till att stärka } \\
\text { ländernas arbete med att } \\
\text { förebygga alkohol- och } \\
\text { narkotikaproblem och främja } \\
\text { kvaliteten på missbruksvården } \\
\text { vid aktivt at förmedla relevant } \\
\text { forskning genom t.ex. utgivande }\end{array}$ & $\begin{array}{l}\text { NVC vill förstärka sin roll som } \\
\text { nordiskt resurs- och } \\
\text { kunskapscenter inom det } \\
\text { välfärdspolitiska området. } \\
\text { Välfärdspolitik: } \\
\text { NVC förmedlar aktivt kunskap } \\
\text { från NVC’s initiativ på området } \\
\text { välfärdspolitik till länderna, } \\
\text { speciellt gällande familjepolitik } \\
\text { samt ett projekt om Fosterbarn i } \\
\text { Norden. Det genomförs } \\
\text { landsturnéer, utbildningsinsatser } \\
\text { och seminarier mm. } \\
\text { NVC har fullföljt en kartläggning } \\
\text { av kvalitetsarbetet i } \\
\text { äldreomsorgen i Norden och } \\
\text { förmedlar denna kunskap till } \\
\text { länderna. } \\
\text { Funktionshindersområdet: } \\
\text { Vidare utveckling av } \\
\text { kursverksamheten på } \\
\text { dövblindområdet, samt fortsatt } \\
\text { erbjudanden om och utveckling } \\
\text { av e-lärningskurser. Fortsatt } \\
\text { fokus på specifika artiklar i FN’s } \\
\text { konvention om funktionshinder. } \\
\text { Uppföljning av handlingsplan för } \\
\text { nordiskt samarbete på } \\
\text { funktionshinderområdet. } \\
\text { Alkohol- och drogforskning: } \\
\text { NVC förmedlar aktivt kunskap } \\
\text { om alkohol och droger bland }\end{array}$ & $\begin{array}{l}\text { NVC har i } 2014 \text { nått drygt } 1000 \\
\text { politiker, tjänstemän och } \\
\text { representanter för } \\
\text { brukarorganisationer i Norden } \\
\text { genom turnéstopp, konferenser, } \\
\text { seminarier och kurser. } 23 \text { nya } \\
\text { publikationer utkom, } 1210 \\
\text { publikationer beställdes, } 287674 \\
\text { personer besökte NVCs hemsida } \\
\text { (+50\%) samt } 708 \text { digitala artiklar } \\
\text { (+51\%) har producerats. } \\
\text { NVC har spridit kunskap om } \\
\text { familjepolitik och uppväxtvillkor } \\
\text { inklusive tidiga insatser i } \\
\text { projekten ”Barn i fosterhem” och } \\
\text { "Barnfattigdom”, haft fokus på } \\
\text { den äldre generationen genom } \\
\text { projektet ”Kvalitet i } \\
\text { äldreomsorgen” samt påbörjat ett } \\
\text { nordiskt demensnätverk. } \\
\text { NVC har ökat kompetensen bland } \\
\text { personer som arbetar i } \\
\text { dövblindområdet genom } \\
\text { kursverksamhet, nätverk och } \\
\text { arbetsgrupper. Nyckelpersoner i } \\
\text { Norden har fått fler verktyg för } \\
\text { att implementera FN- } \\
\text { konventionen för personer med } \\
\text { funktionsnedsättning. } \\
\text { NVC har arbetat med frågor som } \\
\text { rör skador på andra än den som } \\
\text { dricker och utveckling av } \\
\text { missbruksvård i kommunerna, }\end{array}$ \\
\hline
\end{tabular}


seminarier mv.

Vidareutvecklingen av NVC:s roll inom det förebyggande området ska undersökas.

NVC faciliterar utbyte av erfarenheter på demensområdet genom fortsatt stödd till arbetet i det nordiska demensnätverket. annat genom t.ex. utgivande av tidskriften NAD (Nordic Studies on Alcohol and Drugs), och utveckling av PopNAD webbportalen, arrangera seminarier mv.

Välfärdsteknologi:

Uppstart av Fas 2 i det nordiska projektet inom välfärdsteknologi under "Hållbar nordisk välfärd".

Arbetsinkludering:

Vidareutveckling och drift av Nordisk Kunskapsbank om avhopp.

Vidareutveckla samarbetet med nordiska expertmiljöer kring utsatta unga. Kunskapsfördjupning om unga förtidspensionärer i Norden. Arrangera seminarer och workshops om unga, psykisk ohälsa och förtidspensionering.

\section{3-4381 Nordic School of Public Health NHV*}

\section{Institution}

\begin{tabular}{|l|c|c|c|c|c|} 
Valuta & Budget 2016 & Budget 2015 & Budget 2014 & NMR fin. 14 & Budget disp. af \\
\hline SEK & 0 & 0 & 45.989 .000 & $0 \%$ & Institutionen \\
\hline Modsv. DKK & 0 & 0 & 40.010 .000 & &
\end{tabular}

*NHV er finansieret direkte af landene, og indgår derfor ikke i de akkumulerede beløb

Formål

MR-S besluttede i 2013 at nedlægge Nordic School of Public Health NHV med sigte på at skolen er afviklet senest den 1. januar 2015. Denne beslutning blev bekræftet af MRSAM og præsenteret som Ministerrådsforslag på Nordisk Råds session i oktober 2013. Den 31. december 2014 ophørte uddannelses- og forskningsvirksomheden på NHV. Skolens bestyrelse har ansvaret for den endelige afvikling af NHV under 2015. De få resterende administrative opgaver, som ikke kan blive færdige under 2015, skal overføres til Nordens Velfærdscenter (NVC) i Stockholm.

Ifølge $\S 7$ stk. 3 i skolens vedtægter skal skolens ejendom tilfalde Nordisk Ministerråd når virksomheden ophører. Ved lukningen af skolen i 2015 forventes at der vil være en egenkapital til rådighed for nyt nordisk samarbejde inden for området folkehelse. 


\section{Kulturpolitik}

\section{Generel indledning}

Formål og Syftet med det nordiska kultursamarbetet är, enligt den av de nordiska kulturministrarna Fakta

Strategiske
målsætninger
2016
beslutade strategin för det nordiska kultursamarbetet 2013-2020, att förvalta det nordiska kulturarvet inom historia, kultur och språk och på så sätt säkra en kontinuitet. Samtidigt är det nödvändigt att införliva nya kulturuttryck och impulser. Förändringar i kulturlivets och konstens villkor, i befolkningssammansättning, teknik med mera, ställer krav på flexibilitet och förnyelse.

Genom erfarenhets- och kompetensutbyte samt nätverksbyggande ska Norden som region utvecklas och stärkas. Språkförståelsen i Norden ska främjas och understödjas. Principerna om yttrandefrihet och armslängds avstånd ska försvaras. Ett brett förankrat kulturellt samarbete ska utveckla gemenskap och förståelse mellan invånarna i Norden och därmed bidra till de nordiska välfärdssamhällenas sammanhållning.

Nordiska ministerrådets strategi för det nordiska kultursamarbetet 2013-2020 innehåller fem prioriterade teman med strategiska målsättningar:

Det hållbara Norden - Det nordiska kulturlivet stärker hållbarheten i de nordiska samhällena genom att vara tillgänglig och involverande Det kreativa Norden - Norden utmärker sig som en levande, dynamisk och kreativ kulturregion.

Det interkulturella Norden - Alla invånare i Norden känner sig hemma och kulturellt delaktiga i Norden.

Det unga Norden - Barn och unga i Norden skapar, tar del av och har åsikter om konst och kultur.

Det digitala Norden - Nordisk kultur drar full nytta av den digitala tekniken.

Kulturministrarna framhåller att forskning och ett ökat kunskapsunderlag ska prioriteras i arbetet med att genomföra strategin. Strategin ska tjäna som styrdokument för institutioner och samarbetsorgan inom ministerrådet för kultur. Strategin realiseras genom institutionernas egna verksamhetsmål; i budgettexter som anger prioriteringarna för kommande år; i de strategiska satsningar som kulturministrarna beslutar; genom att stärka samarbetet med de nationella kulturmyndigheterna; genom att stärka dialogen på alla nivåer och med andra sektorer; genom ordförandeskapsaktiviteter.

Ministerrådets Resultatberättelsen för MR-K beskriver de resultat som är utöver det som är beskrivet i resultater i 2014 de enskilda budgetposterna, dvs. i tillägg till det som MR-K:s institutioner, samarbetsorgan och programverksamheter har genomfört för att realisera strategin.

Lyft och pris for nordiska barn- och ungdomslitteratur

I 2013 blev Nordisk Råds børne- og ungdomslitteraturpris uddelt første gang. Samtidig igangsatte Nordisk Ministerråd for kultur et såkaldt løft som skal skabe aktiviteter omkring børne- og ungdomslitteraturen samt om prisen.

Prisen er kommet godt fra start og der er positive signaler om at den i et vist omfang har effekt på antallet af oversættelser af børne- og ungdomslitteratur mellem landene.

Således har der f.eks. ligefrem været konkurrence mellem forlag om at købe rettighederne til nogle af titlerne, allerede når de nominerede værker annonceres. Det viser, at prisen kan være med til at gøre børne- og ungdomslitteraturen mere synlig og bevirke, at forlagene er mere tilbøjelige til at satse på at oversætte og udgive nabolandenes værker. Nordisk børne- og ungdomslitteratur er velkendt og har en stærk profil ude i verden. Leipzig, Bologna, Göteborg og Frankfurt er blot eksempler på de 
mange bogmesser og festivaler, som prisen er blevet præsenteret på i 2014. I september gik f.eks. alle de nordiske litteraturkontorer - med Sveriges Kulturråd i spidsen sammen om at lave en markering på Bogmessen i Göteborg hvor de fleste af de 13 nominerede forfattere til Nordisk Råds børne- og ungdomslitteraturpris var på plads og deltog i "Ung Scen" programmet.

Blandt aktiviteterne i løftet var der også i sommeren 2014 Nordisk forfatterskole for unge på Biskops Arnö med deltagelse af unge fra ikke mindre end 7 nordiske lande og områder. Alle deltagerne i årets forfatterskole kunne benytte deres modersmål i skrivearbejdet og i kommunikationen med deres vejledere på kurset. Ved de fælles seancer foregik kommunikationen på 'blandinavisk'. Udover forfatterskolen, har løftet i 2014 givet støtte til bl.a oversættelser, seminar for författare og illustratorer, forfatterbesøg på skoler, unge litteraturbloggere og netværksaktiviteter.

Kultur och hållbar utveckling

Kultursektoren har i 2013 haft et særligt fokus på holdbar udvikling. Kultur og holdbar udvikling er ét af fem prioriterede områder i Strategi for nordisk kultursamarbejde 2013 - 2020. Kultur har i 2013 blandt andet bidraget med en del-session på den nordiske holdbarhedskonference i september i Umeå hvor bæredygtig lcering og kultur var ét af fokusområderne på konferencen. Nordisk Ministerråd er initiativtager til projektet "Culture and Sustainable Development" som er et flagskibsprojekt i realiseringen af EU’s Østersøstrategi. Projektets overordnede formål er at opbygge viden om kultur som drivkraft for en bæredygtig udvikling. Dette sker gennem fremme af gode/bedste/ næste praksis for, hvordan kultur kan bidrage til en bæredygtig udvikling i Østersøregionen. Projektet " Culture and Sustainable Development” har tre tværfaglige fokusområder: Byudvikling, Kreative Industrier og Social Innovation. Projektet drives af Nordisk Ministerråds kontor i Riga og er fortsat i 2014.

\section{Rekommandationer}

Nordisk Ministerråd for kultur har i 2014 lagt en stor indsats i forhold til at behandle særligt to rekommandationer fra Nordisk Råd. Det drejer sig om rekommandation om harmonisering af vedtægterne for Nordisk Råds priser samt rekommandation om at udrede fordele og ulemper ved at sammenlægge Nordisk Kulturfond og Kulturkontakt Nord.

\section{Harmonisering af vedtcegter for Nordisk Råds priser}

Nordisk Ministerråd har gennemført en analyse og en dialogproces om Nordisk Råds Priser, for at give et solidt grundlag for revideringer af vedtægterne. Analysearbejdet har involveret Nordisk Råd, Ministerrådene for Kultur og Miljø, sekretariaterne ved Nordisk Råd og Nordisk Ministerråd inklusive Kommunikationsafdelingen, medlemmer af bedømmelseskomiteerne og prissekretariaterne. Dermed er analysens konklusioner forankrede i en bred kreds. Analysen og dens resultater blev forelagt Nordisk Råd i slutningen af 2013 og rådet har færdigbehandlet rekommandationen. Hjørnestenen i analysens konklusioner var at revidere gældende vedtægter for de 5 nordiske priser med virkning fra 1.12016 samt, at harmonisere det administrative arbejde omkring priserne, til den grad det er formålstjenligt. Nordisk Ministerråd for kultur har gennem 2014 arbejdet videre med at konkretisere revidering af vedtægter og harmonisering af det administrative arbejde. Et forslag til reviderede vedtægter samt en håndbog for hver af priserne er fremlagt til behandling på Nordisk Råds session 2015 og træder i kraft 1. januar 2016.

Et fælles overordnet formål er skrevet ind i alle vedtægter:

Formålet med Nordisk Råds priser er at øge interessen for det nordiske kulturfeellesskab og miljøsamarbejde og at anerkende enestående kunstneriske og miljømcessige 
indsatser. Priserne skal bidrage til at synliggøre og markere det nordiske samarbejde.

Redegørelse om sammenlegnning af Nordisk Kulturfond og Kulturkontakt Nord I 2013 rekommanderede Nordisk Råd, at Nordisk Ministerråd skulle udrede, om der er effektiviserings- og rationaliseringsgevinster ved at sammenlægge Nordisk Kulturfond og Kulturkontakt Nord, og se på effekter og fordele og ulemper for det kulturpolitiske arbejde. Nordisk Ministerråd har udformet redegørelsen og den er tilgået Nordisk Råd i midten af september 2014. Spørgsmålet om en sammenlægning af Nordisk Kulturfond og Kulturkontakt Nord har været oppe et antal gange siden Kulturkontakt Nord blev etableret i 2008. Konklusionerne på diverse rapporter og udredninger har på mange måder været enslydende: Så længe ejerstrukturen er så væsensforskellig i de to organer som tilfældet er, nytter det ikke at tale om en sammenlægning. Hidtil er der ikke været politisk ønske om eller vilje til at ændre på denne struktur. Redegørelserne har også slået fast, at begge systemer fungerer godt. Redegørelsen slår fast, at såvel Kulturkontakt Nord som Nordisk Kulturfond har høj legitimitet og at det opleves som positivt, at der findes flere typer systemer og ordninger som kan gavne forskellige typer ansøgere.

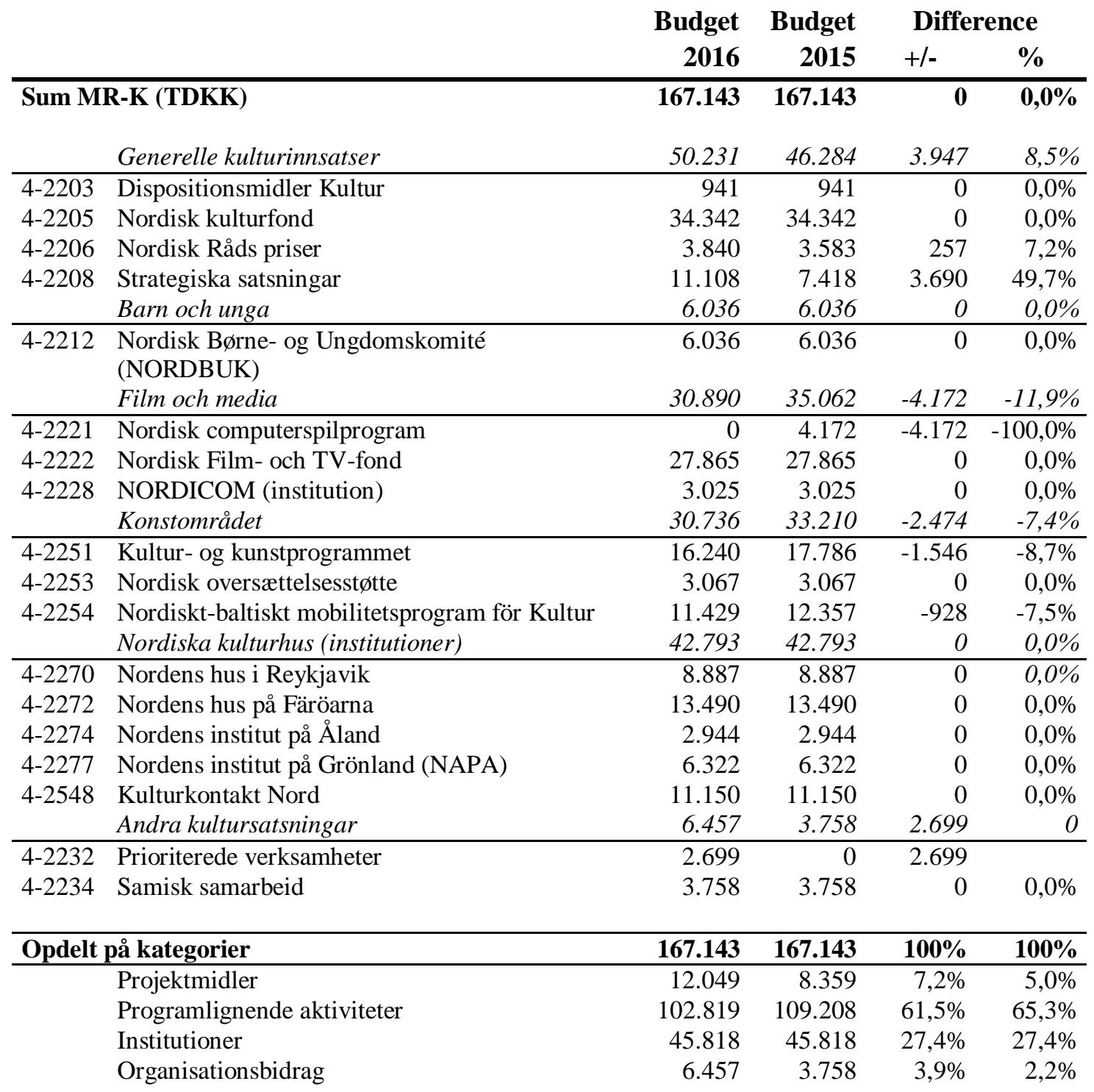




\section{Generelle Kultursatsningar}

4-2203 Dispositonsmidler Kultur

Projektmidler

\begin{tabular}{|l|c|c|c|c|c|} 
Valuta & Budget 2016 & Budget 2015 & Budget 2014 & Disp./bud. 14 & Budget disp. af \\
\hline DKK & 941.000 & 941.000 & 1.028 .000 & $92 \%$ & MR-K/ÄK-K
\end{tabular}

Formål Budgetposten har som syfte att finansiera politiska initiativ, (inklusive policy grupper och arbetsgrupper), analyser och rapporter som ska främja arbetet med att realisera kulturministrarnas strategi för det nordiska kultursamarbetet 2013-2020.

I overensstemmelse med den af MR-K besluttede strategi for 2013-2020 er følgende mål fastlagt for 2016.

\begin{tabular}{|c|c|c|}
\hline \multicolumn{3}{|l|}{ Mål og resultatopfølgning } \\
\hline 2016 - Mål & 2015 - Mål & 2014 - Opnåede resultater \\
\hline $\begin{array}{l}\text { Medel från budgetposten ska } \\
\text { finansiera rapporter, förstudier, } \\
\text { utvärderingar och konferenser } \\
\text { som syftar till att ge } \\
\text { kulturministrarna underlag till } \\
\text { möjliga initiativ inom kultur- och } \\
\text { medieområdet. }\end{array}$ & $\begin{array}{l}\text { Medel från budgetposten ska } \\
\text { finansiera rapporter, förstudier, } \\
\text { utvärderingar och konferenser } \\
\text { som syftar till att ge } \\
\text { kulturministrarna underlag till } \\
\text { möjliga initiativ inom kultur- och } \\
\text { medieområdet. Dessutom medel } \\
\text { till Nordiska rådets prisgala - } 300 \\
\text { 000 DKK. }\end{array}$ & $\begin{array}{l}\text { Medel från budgetposten har } \\
\text { finansierat rapporter, förstudier, } \\
\text { utvärderingar och konferenser } \\
\text { som har syftat till att ge } \\
\text { kulturministrarna underlag till } \\
\text { möjliga initiativ inom kultur- och } \\
\text { medieområdet. Nämnas kan } \\
\text { utredningen om en eventuell } \\
\text { sammanläggning av Nordiska } \\
\text { kulturfonden och Kulturkontakt } \\
\text { Nord, dokumentation av Nordic } \\
\text { Media and Gender Forum, medel } \\
\text { till Nordiska rådets prisgala, } \\
\text { beviljning till Nordiska rådets } \\
\text { musikpris } 50 \text { år. }\end{array}$ \\
\hline
\end{tabular}

\section{4-2205 Nordisk Kulturfond}

Programlignende aktiviteter

\begin{tabular}{|l|c|c|c|c|c|} 
Valuta & Budget 2016 & Budget 2015 & Budget 2014 & Disp./bud. 14 & Budget disp. af \\
\hline DKK & 34.342 .000 & 34.342 .000 & 34.525 .000 & $100 \%$ & Fondstyret
\end{tabular}

Formål Fondens opgave er at fremme det kulturelle samarbejde mellem de nordiske lande. Ifølge overenskomsten omfatter Fondens virksomhedsområde det nordiske kultursamarbejde i hele dets udstrækning inden for og uden for Norden.

I overensstemmelse med den af Nordisk Kulturfonds bestyrelses besluttede strategi er følgende mål fastlagt for 2015:

\begin{tabular}{|l|l|l|}
\hline Mål og resultatopfølgning \\
\hline 2016 - Mål & 2015 - Mål & 2014 - Opnåede resultater \\
\hline Der indarbejdes nye kriterier og & På baggrund af omverdens- & Fonden har i 2014 modtaget 930 \\
\hline
\end{tabular}


retningslinjer for at søge støtte til fondens regulære pulje i 2016, som skal bidrage til at højne kvaliteten af ansøgninger. Fonden forventer at modtage ca. 1.000 ansøgninger, af dem bliver omkring 700 realitetsbehandlet og ca. 170 får støtte. Fonden vil fortsat arbejde med en kvikpulje, OPSTART, som skal gøre det lette at komme i gang med det nordiske samarbejde. Hertil forventer Fonden at behandle ca. 200 ansøgninger og give støtte til ca. 75 OPSTARTS-projekter.

Fonden vil endvidere foretage en ny brugerundersøgelse. I 2016 vil Fonden udpege de projekter, som får støtte i den tematiske satsning HANDMADE. Det vil dreje sig om 3-6 projekter, og Fonden vil sammen med støttemodtagerne arbejde for at kvalificere projekterne. I sin kommunikation vil Fonden arbejde for at nå nye målgrupper og styrke sin netværkskommunikation med centrale kulturaktører i hele Norden. Målet er at højne kvaliteten og sænke tærsklen for at deltage i det nordiske kultursamarbejde. analysen udarbejdet af Rokkan Sentret, Bergens Universitet i 2014, og en gennemført brugerundersøgelse vil Fonden i dialog med NMR og NR udarbejde en virksomhedsplan, der skal sikre, en fortsat udvikling af Nordisk Kulturfond som et proaktivt samarbejdsorgan, der fremmer kultursamarbejdet og samhørigheden i Norden. For at fremtidssikre samarbejdet vil der fortsat være fokus på involvering af de unge borgere, og på de borgere der har rødder andre steder end i Norden. ansøgninger, realitetsbehandlet 681 og bevilget støtte til 201 projekter. Fonden har gennemført en brugerundersøgelse og modtaget en omverdensanalyse gennemført af Rokkan Sentret i Bergen. Dertil har Fonden udarbejdet og vedtaget en ny kommunikations- og brandingstrategi som bl.a. fokuserer på netværkskommunikation og udviklings af en ny visuel identitet. I juni udpegede fondens bestyrelse Årets Digitale Kulturbegivenhed 2015-2016 til at være HYBRID MATTERS. Dertil vedtog bestyrelsen på baggrund af en analyse af Årets Nordiske Kulturbegivenhed fremover i højere grad at arbejde med tematiske satsninger. I 2014 har Fonden desuden gennemført en sprogtænketank med deltagelse af nordiske kunstnere samt en dialogworkshop med bevillingsmodtagere.

\section{4-2206 Nordisk Råds priser}

\section{Programlignende aktiviteter}

\begin{tabular}{|l|c|c|c|c|c|} 
Valuta & Budget 2016 & Budget 2015 & Budget 2014 & Disp./bud. 14 & Budget disp. af \\
\hline DKK & 3.840 .000 & 3.583 .000 & 3.530 .000 & $98 \%$ & MR-K/ÄK-K
\end{tabular}

Formål

Formålet med Nordisk Råds kulturpriser er at øge interessen for det nordiske kulturfællesskab samt at anerkende enestående kunstneriske indsatser. Priserne skal bidrage til at markere det formelle nordiske samarbejde.

Nordisk Råds fire prissekretariater for hhv. Litteraturprisen, børne- og ungdomslitteraturprisen, filmprisen og musikprisen.

Från budgetpost 4-2208 Strategiska satsningar förs 257 TDKK till budgetposten för att harmonisera antalet medlemmar i musikpriset med antalet medlemmar i litteraturpriserna.

I overensstemmelse med den af MR-K besluttede strategi for 2013-2020 er følgende 
mål fastlagt for 2016:

\begin{tabular}{|c|c|c|}
\hline \multicolumn{3}{|l|}{ Mål og resultatopfølgning } \\
\hline 2016 - Mål & 2015 - Mål & 2014 - Opnåede resultater \\
\hline $\begin{array}{l}\text { De fire nordiske kulturpriser } \\
\text { uddeles jf. vedtægterne. } \\
\text { Priserne skal synliggøres, } \\
\text { profileres og markedsføres til } \\
\text { relevante professionelle aktører } \\
\text { og for et bredt publikum både i } \\
\text { og uden for Norden. } \\
\text { For at øge interessen for det } \\
\text { nordiske kulturfællesskab samt } \\
\text { bidrage til at anerkende } \\
\text { enestående kunstneriske indsatser } \\
\text { vil der blandt andet blive } \\
\text { gennemført en større markering i } \\
\text { form af en prisuddeling. } \\
\text { Ydermere skal interessen for } \\
\text { priserne øges ved deltagelse på } \\
\text { festivaler og messer både i og } \\
\text { uden for Norden. } \\
\text { Reviderede vedtægter for } \\
\text { priserne skal implementeres fra } \\
\text { 2016 sammen med en ny } \\
\text { håndbog for hver pris som } \\
\text { angiver hvem der har ansvar for } \\
\text { de forskellige dele af arbejdet og } \\
\text { som skal være en støtte i det } \\
\text { daglige arbejde omkring prisen. } \\
\text { Dette vil blandt andet styrke } \\
\text { transparensen omkring arbejdet } \\
\text { med priserne og tydeliggøre de } \\
\text { forskelle organers mandat og } \\
\text { ansvar. }\end{array}$ & $\begin{array}{l}\text { De fire nordiske kulturpriser } \\
\text { uddeles jf. vedtægterne. } \\
\text { Priserne skal synliggøres, } \\
\text { profileres og markedsføres til } \\
\text { relevante professionelle aktører } \\
\text { og for et bredt publikum både i } \\
\text { og uden for Norden. } \\
\text { For at øge interessen for det } \\
\text { nordiske kulturfællesskab samt } \\
\text { bidrage til at anerkende } \\
\text { enestånde kunstneriske indsatser } \\
\text { vil der blandt andet blive } \\
\text { gennemført en større markering i } \\
\text { form af en prisuddeling. } \\
\text { Ydermere skal interessen for } \\
\text { priserne øges ved deltagelse på } \\
\text { festivaller og messer både i og } \\
\text { uden for Norden. } \\
\text { For at sikre en kontinuerlig } \\
\text { udvikling og en optimering af } \\
\text { administrationen af Nordisk Råds } \\
\text { priser, fremlægges et } \\
\text { ministerrådsforslag på Nordisk } \\
\text { Råds session med forslag til } \\
\text { reviderede og harmoniserede } \\
\text { vedtægter for Nordisk Råds } \\
\text { Priser (inkl. Miljøprisen). Der er } \\
\text { tillige udformet en håndbog for } \\
\text { hver pris som angiver hvem der } \\
\text { har ansvar for de forskellige dele } \\
\text { af arbejdet og som skal være en } \\
\text { støtte i det daglige arbejde } \\
\text { omkring prisen. }\end{array}$ & $\begin{array}{l}\text { De fire priser blev uddelt jf. } \\
\text { vedtægterne. } \\
\text { Med målet om at synliggøre } \\
\text { priserne og det nordiske } \\
\text { samarbejde, er der gennemført en } \\
\text { prisuddeling og produceret en tv } \\
\text { udsendelse om vinderene af årets } \\
\text { priser, som blev vist på de fem } \\
\text { nordiske landes public service } \\
\text { kanaler. } \\
\text { Der er pågået et omfattende } \\
\text { arbejde i en dialog mellem } \\
\text { prisernes sekretariater og Nordisk } \\
\text { Råd og Nordisk Ministerråd for } \\
\text { at belyse behovet for } \\
\text { harmoniseringer og revideringer } \\
\text { af de gældende vedtægter og } \\
\text { administrative rammeværker og } \\
\text { rutiner omkring priserne. } \\
\text { Arbejdet resulterer i et } \\
\text { ministerrådsforslag som skal } \\
\text { træde i kraft } 1.12016 .\end{array}$ \\
\hline
\end{tabular}




\section{4-2208 Strategiska satsningar}

Projektmidler
\begin{tabular}{|l|c|c|c|c|c|} 
Valuta & Budget 2016 & Budget 2015 & Budget 2014 & Disp./bud. 14 & Budget disp. af \\
\hline DKK & 11.108 .000 & 7.418 .000 & 7.333 .000 & $85 \%$ & MR-K/ÄK-K
\end{tabular}

Formål

Budgetposten ska understödja strategin för det nordiska kultursamarbetet 2013-2020, vars överordnade teman är "Det hållbara Norden, Det unga Norden, Det digitala Norden, Det kreativa Norden och Det interkulturella Norden.”

Nordiska datorspelsprogrammets budgetpost läggs ner (budgetpost 4-2221) och den totala budgeten för 2015 på 4.172 TDKK förs över till Strategiska satsningar. Från budgetposten förs 257 TDKK till budgetposten 4-2206 Nordiska rådets priser og 225 TDKK till den nya budgetposten Prioriterade verksamheter, 4-2232.

Medlen ska även användas till ordförandeskapsaktiviteter och konferenser som främjar arbetet med att realisera strategin, och bidra till att politiken och praktiken kan fatta beslut av relevans och implementera dessa med följande mål:

\begin{tabular}{|c|c|c|}
\hline \multicolumn{3}{|l|}{ Mål og resultatopfølgning } \\
\hline 2016 - Mål & 2015 - Mål & 2014 - Opnåede resultater \\
\hline $\begin{array}{l}\text { Under } 2015 \text { ska MR-K värdera } \\
\text { en eventuell satsning med } \\
\text { tillhörande beslut om } \\
\text { budgetmedel till en } \\
\text { kunskapsresurs för nordisk } \\
\text { kulturpolitik och nordisk } \\
\text { kulturstatistik; kulturens roll i } \\
\text { förhållande till civilsamhället; } \\
\text { kultur och yttrandefrihet; } \\
\text { digitalisering inklusive projekt } \\
\text { om arkivportal och gemensam } \\
\text { inköpsordning för nordiska } \\
\text { bibliotek av medier på andra } \\
\text { språk än skandinaviska; barns } \\
\text { och ungas användande av } \\
\text { digitala medier och datorspel; } \\
\text { Nordisk kultur i världen } \\
\text { inklusive stärkande av nordiskt- } \\
\text { baltiskt kultursamarbete. MR-K } \\
\text { ska under } 2015 \text { besluta om ev. } \\
\text { medel om fortsatt satsning på } \\
\text { nordisk musikexport och } \\
\text { nordisk dansplattform. } \\
\text { Av anslaget ska 1,3 miljoner } \\
\text { DKK gå till Ett lyft för nordisk } \\
\text { barn- och ungdomslitteratur. } \\
\\
\text { Av anslaget ska } 1 \text { miljon DKK } \\
\text { gå till Nordisk Journalistcenter } \\
\text { som stöd för yttrandefrihet och }\end{array}$ & $\begin{array}{l}\text { Understödja det kulturpolitiska } \\
\text { området genom att genomföra } \\
\text { följande aktiviteter; } \\
\text { NJC - särskilda insatser för } \\
\text { främjande av journalistiska } \\
\text { uppgifter i Norden, enligt } \\
\text { överenskommelse med Nordiska } \\
\text { Rådet. } \\
\text { NOMEX - Nordic Music Export } \\
\text { Program fortsatt utveckling av } \\
\text { den nordiska } \\
\text { samarbetsplattformen för att } \\
\text { stärka och utveckla nordisk } \\
\text { musik i Norden och } \\
\text { internationellt. Profilera Nordisk } \\
\text { dans internationellt för att skapa } \\
\text { större synlighet och } \\
\text { arbetstillfällen för nordiska } \\
\text { danskompanier genom IceHot, } \\
\text { nordisk dansplattform. Bidra till } \\
\text { att realisera målsättningarna i } \\
\text { kulturministrarnas strategi för } \\
\text { det nordiska kultursamarbetet } \\
\text { genom } \\
\text { ordförandeskapsaktiviteter. } \\
\text { Synliggöra nordisk barn- och } \\
\text { ungdomslitteratur och att öka } \\
\text { kunskapen om ländernas barn- } \\
\text { och ungdomslitteratur i de } \\
\text { övriga nordiska länderna genom } \\
\text { Ett lyft för nordisk barn- och }\end{array}$ & $\begin{array}{l}\text { Budgetposten har använts till } \\
\text { aktiviteter som syftar till att } \\
\text { understödja strategin för det } \\
\text { nordiska kultursamarbetet, bl.a. } \\
\text { Nordisk Journalistcenter- } \\
\text { genomförda kurser och kulturträffar } \\
\text { för nordiska journalister och } \\
\text { redaktörer med perspektiv på nya } \\
\text { arbetsrutiner och roller och samspel } \\
\text { mellan olika mediekanaler i det } \\
\text { digitala Norden, som bidragit till } \\
\text { implementeringen av } \\
\text { kulturstrategins tema digitalisering. } \\
\text { NOMEX - Nordic Music Export } \\
\text { Program har framtagit verktyg som } \\
\text { medverkar till att stärka den } \\
\text { intranordiska musikmarknaden; } \\
\text { bland annat Nordic Playlist och } \\
\text { Nordic Travel Pass. Programmet } \\
\text { har upprättat och genomfört } \\
\text { internationellt samarbete genom } \\
\text { nätverksplattformar och } \\
\text { arrangemang vid festivaler i } \\
\text { London, Madrid och Tokyo. } \\
\text { Programmet har genomfört ett } \\
\text { system för support av tjänster med } \\
\text { informationsdelning kring strategier } \\
\text { och initiativ mellan de fem } \\
\text { nationella musikexportkontoren. } \\
\text { Det nordiska dansnätverket IceHot } \\
\text { har genomfört nätverksaktiviteter i }\end{array}$ \\
\hline
\end{tabular}


journalistik i det digitala

medielandskapet.

Budgetposten kan också ses i

sammanhamng med

tvärsektoriella initiativ inom

ramen för

Prioriteringsbudgeten, t.ex

Nordisk statistik. ungdomslitteratur. Delfinansiera

en utvärdering av KreaNord.
Sydamerika, Asien och Australien, ingått en överenskommelse med American Dance abroad om utbyte samt genomfört festivalen IceHot Oslo allt för att profilera nordisk dans internationellt. Arbete med en utvärdering av projektet är igångsatt. Ett lyft för Nordisk barnoch ungdomslitteratur - se ovan under Ministerrådets resultat 2014.

\section{Børn og Unge}

\section{4-2212 Nordisk Børne- og Ungdomskomité (NORDBUK)}

\section{Programlignende aktiviteter}

\begin{tabular}{|l|c|c|c|c|c|} 
Valuta & Budget 2016 & Budget 2015 & Budget 2014 & Disp./bud. 14 & Budget disp. af \\
\hline DKK & 6.036 .000 & 6.036 .000 & 6.068 .000 & $97 \%$ & NORDBUK
\end{tabular}

Formål Nordiska barn- och ungdomskommittén (NORDBUK) är Nordiska ministerrådets rådgivande och samordnande organ i barn- och ungdomspolitiska frågor. NORDBUK ska samla och sprida kunskap om barn och ungas levnadsvillkor i Norden, stödja barn och ungas egen organisering och delaktighet i demokratiska processer samt främja integrering av ett barn- och ungdomsperspektiv inom Nordiska ministerrådet. I överensstämmelse med implementering av NORDBUK:s handlingsplan 2014-2017 är följande mål fastställda för 2016.

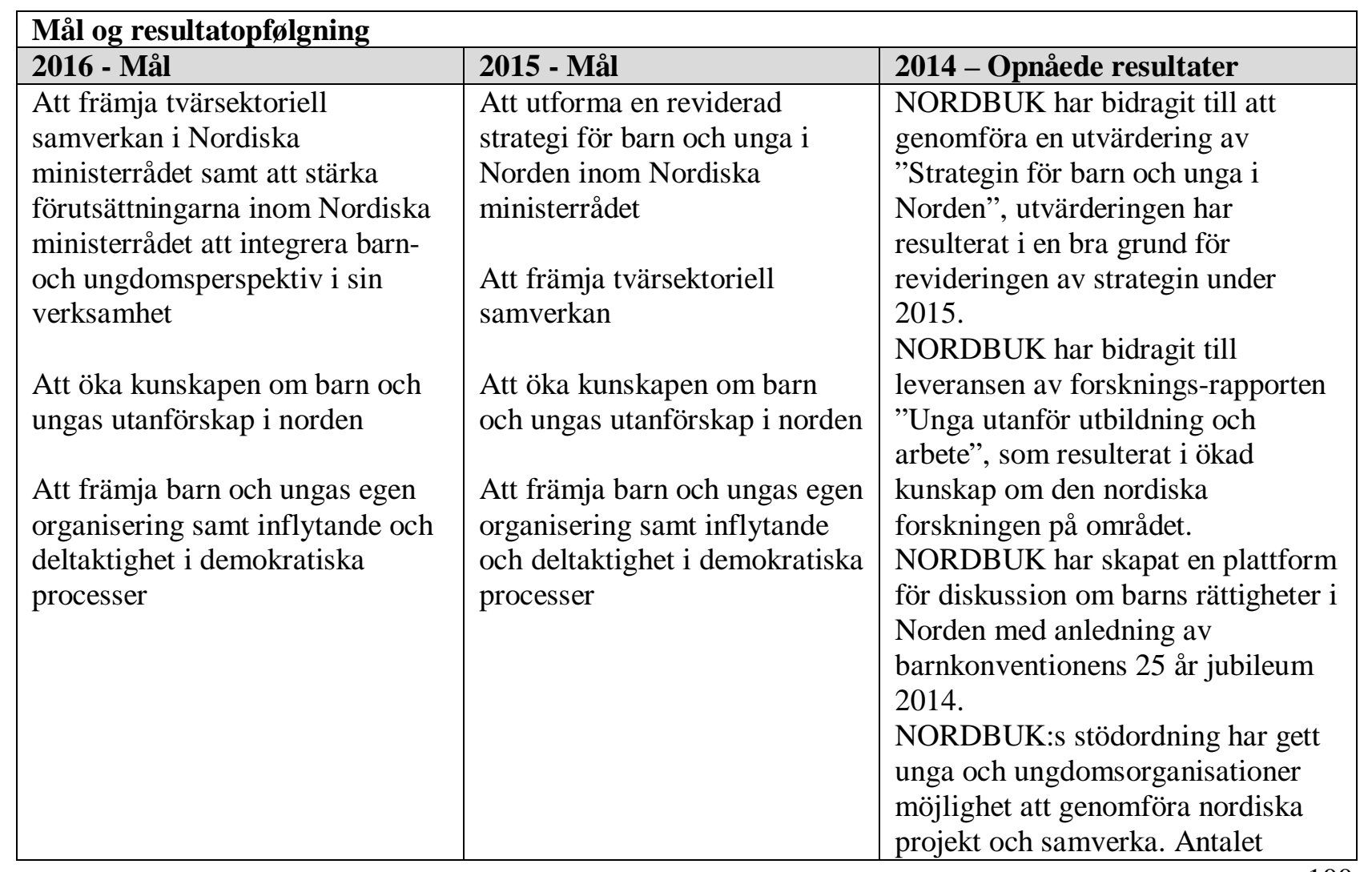




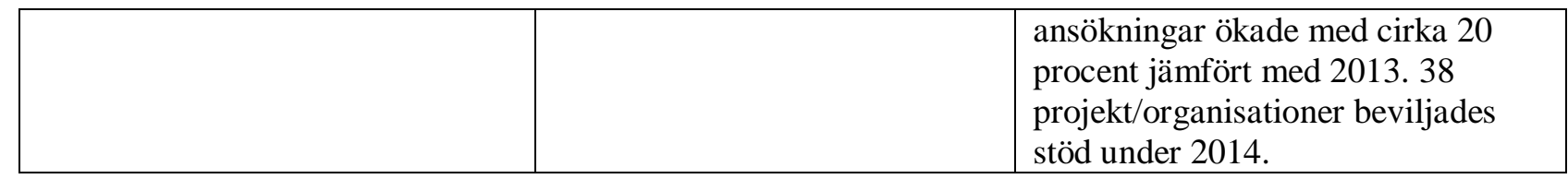

Målen för 2016 realiseras huvudsakligen genom att ta fram en implementeringsplan och verktyg som stöd till sektorerna inom Nordiska ministerrådet, genomföra fler spridningsaktiviteter jämfört med tidigare år, fördela bidrag i enlighet med NORDBUK-programmets syfte samt genomföra en översyn av NORDBUK:s bidragsgivning syftande till att beakta bidragsgivningens funktion inom NORDBUK:s verksamhet.

\section{Film og Media}

4-2221 Nordisk computerspilprogram

Programlignende aktiviteter
\begin{tabular}{|l|c|c|c|c|c|} 
Valuta & Budget 2016 & Budget 2015 & Budget 2014 & Disp./bud. 14 & Budget disp. af \\
\hline DKK & 0 & 4.172 .000 & 6.610 .000 & $100 \%$ & MR-K/ÄK-K
\end{tabular}

Formål $\quad$ Att arbeta för en ökad kvalitet och tillgång till nordiskt producerade dataspel för barn och unga (ramavtal från 1/1-2013).

Nordiska datorspelsprogrammets budgetpost läggs ner och den totala budgeten för 2015 på 4172 TDKK förs över till budgetpost 4-2208 Strategiska satsningar.

Forvaltnings- $\quad$ NGI (Nordic Game Institute)

organ

Kontraktperiode Övriga uppgifter om beviljningen:

og -status Kontraktperiode: 2013-2015

\begin{tabular}{|l|l|l|}
\hline Mål og resultatopfølgning & 2015 - Mål & 2014 - Opnåede resultater \\
\hline 2016 - Mål & $\begin{array}{l}\text { Utvecklingsstöd till spelprojekt - } \\
\text { utdelat stöd från 2014 avslutas. 1 } \\
\text { Datorspelprogrammets } \\
\text { nuvarande kontrakt upphör } \\
2015 .\end{array}$ & $\begin{array}{l}\text { Exportaktiviteter till nordiska } \\
\text { verksamheter och gemensamma } \\
\text { kampanjer vid tre internationella } \\
\text { genomföra en extraordinär } \\
\text { ansökningsomgång också i 2015. } \\
\text { Ansökningar behandlas av den } \\
\text { självständiga expertkommittén. } \\
\text { Deverenser-mässor (Game } \\
\text { Devers Conference, San } \\
\text { Francisco; GamesCom, Köln; } \\
\text { Game Connection Europe, Paris). } \\
\text { Exportaktiviteterna justeras således } \\
\text { att utöver deltagande i } \\
\text { internationella mässor, etableras ett } \\
\text { event i Reykjavik i april 2015, med } \\
\text { attrahera internationella aktörer } \\
\text { till Norden. }\end{array}$ \\
& syfte att samla internationella \\
branschaktörer i Norden. & $\begin{array}{l}\text { Nordic Game Conference och } \\
\text { Nordic Game Award har } \\
\text { arrangerats med högre } \\
\text { deltagarantal än tidigare. }\end{array}$ \\
& $\begin{array}{l}\text { Nordic Game Conference samt } \\
\text { Nordic Game Award - genomförs } \\
\text { 2015 liksom år 2013 och 2014. }\end{array}$ & $\begin{array}{l}\text { Under 2014 inkom 185 } \\
\text { ansökningar om utvecklingsstöd av } \\
\text { spel, och utav dessa fick nio }\end{array}$ \\
\hline
\end{tabular}




\begin{tabular}{|l|l|l|}
\hline & $\begin{array}{l}\text { På bakgrund av behovsanalysen } \\
\text { om utbildningsbehov som } \\
\text { genomfördes 2014, kommer } \\
\text { utvalda utbildningsaktiviteter att } \\
\text { genomföras. }\end{array}$ & $\begin{array}{l}\text { utveckingstöd. Detta har bidragit } \\
\text { till att fler nordiska datorspel kan } \\
\text { produceras av nya nordiska } \\
\text { producenter. } \\
\text { Den inledda undersökningen av } \\
\text { vilket utbildningsutbud som finns } \\
\text { i Norden har inletts, och slutförs } \\
\text { efter 2015. }\end{array}$ \\
& $\begin{array}{l}\text { Insatsområdet "broader financing” programmets drift } \\
\text { kommer att genom en rapport till } \\
\text { den nordiska branschen genomlysa } \\
\text { möjligheter att bl a erhålla EU } \\
\text { medel för att understödja } \\
\text { utvecklandet av bättre } \\
\text { ramförutsättningar för den } \\
\text { nordiska datorspelbranschen. }\end{array}$ & $\begin{array}{l}\text { Ökat fokus på att skapa bredare } \\
\text { finansiering och fortsatt arbete } \\
\text { med handlingsplanen för detta. } \\
\text { Dokumentation av nordisk nytta. } \\
\text { Säkerställande av att alla } \\
\text { beslutsfattare har relevant } \\
\text { informations så att de är } \\
\text { införstådda med programmets } \\
\text { värde. Ökad information om } \\
\text { finansiering av spel och } \\
\text { aktiviteter inom EU. }\end{array}$ \\
& $\begin{array}{l}\text { Estland är nu en aktiv deltagare i } \\
\text { programmet, ambitionen är att } \\
\text { utvidga detta till att också omfatta } \\
\text { de två andra Baltiska länderna. }\end{array}$ & $\begin{array}{l}\text { Samarbete inlett med } \\
\text { spelbranschen i Estland, som nu } \\
\text { har observatörpost i programmets } \\
\text { styrelse. }\end{array}$ \\
\hline
\end{tabular}

\section{4-2222 Nordisk Film- og TV-fond}

Programlignende aktiviteter

\begin{tabular}{|l|c|c|c|c|c|} 
Valuta & Budget 2016 & Budget 2015 & Budget 2014 & Disp./bud. 14 & Budget disp. af \\
\hline DKK & 27.865 .000 & 27.865 .000 & 27.453 .000 & $100 \%$ & MR-K/ÄK-K
\end{tabular}

Formål $\quad$ Fondens primära syfte är att främja film- och TV- produktioner av hög kvalitet i de fem nordiska länderna genom stöd till top- up finansiering av spelfilmer, TV-fiktion/serier och kreativa dokumentärer.

I överensstämmelse med den av MR-K beslutade strategin för 2013-2020 är följande mål beslutade för 2016 .

\section{Forvaltnings- $\quad$ Nordisk Film \& TV Fond} organ

Kontraktperiode Kontraktperiode: 2015-2019

og -status Kontraktstatus: Pågående

\begin{tabular}{|l|l|l|}
\hline Mål og resultatopfølgning & $\mathbf{2 0 1 5}$ - Mål & $\mathbf{2 0 1 4}$ - Opnåede resultater \\
\hline 2016 - Mål & Den nordiska audiovisuella & $\begin{array}{l}\text { Fonden har bidragit till } \\
\text { främjandet av den nordiska }\end{array}$ \\
Den nordiska audiovisuella & marknaden (producenter, \\
distributen (producenter, & audiovisuella marknaden genom \\
stöd till produktion och & distributörer, publik) främjas via & att bevilja ca NOK 79 million \\
\hline
\end{tabular}


distribution av utvalda film- och teve/dokumentärfilmprojekt av hög kvalitet. Stöd till pannordiska filmkulturella evenemang vidareutvecklas. Projekt för barn och unga prioriteras och leder till högkvalitativa nordiska produkter.

De nya distributionsstödformer som tar hänsyn till nya digitala möjligheter vidareutvecklas för att fungera optimalt för brukarna. Fortsatt talangutveckling görs via fondens eget arrangemang Nordic Talents (samarbete mellan skolor och bransch) och nytt utvecklingsprogram Nordic Genre Boost som inleddes 2015, bidrar till att återväxten och ny professionalism ger Norden fler kvalitativa kulturprodukter.

Av anslaget ska $1.4 \mathrm{M}$ DKK gå till Filmkontakt Nords kort - och dokumentärfilmsverksamhet. distribution av utvalda film- och teve/dokumentärfilmprojekt av hög kvalitet. Stöd till pannordiska filmkulturella evenemang. Projekt för barn och unga prioriteras.

Nya distributionsstödformer som tar hänsyn till nya digitala möjligheter är på plats och fungerar fortsatt.

Fortsatt talangutveckling görs via fondens eget arrangemang Nordic Talents (samarbete mellan skolor och bransch).

Fondens nya femåriga avtal 2015-2019 startar och vidare strategi beslutas enligt prioriteringar från styrelsen efter parternas möte. stöd till produktion och distribution av projekt med hög kvalitet och pan-nordiska filmkulturella evenemang. Prioriterade projekt för barn och unga har fått bidrag med en femtedel av budgeten, vilket möjliggjort högkvalitativ produktion och distribution av film/tv projekt till barn och unga i Norden.

Nya distributionsinitiativen har satts igång och distribution av nordiska filmer i grannländer har nästan fördubblats från 2013.

Innehållet i arrangemanget

Nordic Talents, som skapar kontaktmöjligheten mellan nya talanger och den etablerade branschen, har förnyats som bidrar till fortsatt nordisk produktion för nordisk publik. Ökad publicitet och visningar av de nominerade filmerna till Nordiska Rådets Filmpris, har utvecklat dialogen mellan praktik och politik inom

filmkulturområdet.

\section{4-2228 NORDICOM}

\section{Institution}

\begin{tabular}{|l|c|c|c|c|c|} 
Valuta & Budget 2016 & Budget 2015 & Budget 2014 & NMR fin. 14 & Budget disp. af \\
\hline SEK & 3.644 .000 & 3.644 .000 & 3.614 .000 & $29 \%$ & Institutionen \\
\hline Modsv. DKK & 3.025 .000 & 3.025 .000 & 3.144 .000 & &
\end{tabular}

\section{Formål}

Verksamheten syftar till att utveckla mediekunskapen, bidra till att forskningens resultat synliggörs i behandlingen av mediefrågor på olika nivåer i både offentlig och privat verksamhet samt stimulera samarbete mellan Norden och andra delar av världen. Detta sker genom att insamla, bearbeta och förmedla kunskap från medie och kommunikationsområdet till olika brukargrupper i samhället samt främja kontakterna mellan nordiska medie och kommunikationsforskare och internationella forskningsmiljöer.

I överensstämmelse med den av MR-K beslutade strategin för 2013-2020 är följande mål beslutade för 2016 .

Kontraktperiode Kontraktperiode: 2013-2015

og -status

Kontraktstatus: Ny kontrakt 1. januar 2016. 


\begin{tabular}{|c|c|c|}
\hline \multicolumn{3}{|l|}{ Mål og resultatopfølgning } \\
\hline 2016 - Mål & 2015 - Mål & 2014 - Opnåede resultater \\
\hline $\begin{array}{l}\text { Utveckla Nordicom i } \\
\text { förhållande till massmediernas } \\
\text { förändring i Norden och världen } \\
\text { så att Norden synliggörs både } \\
\text { nationellt, nordiskt och } \\
\text { internationellt. Aktiviteterna ska } \\
\text { genomsyras av såväl relevanta } \\
\text { frågeställningar rörande dagens } \\
\text { medie- och } \\
\text { kommunikationssamhälle som } \\
\text { effektiva samarbeten med olika } \\
\text { aktörer. }\end{array}$ & $\begin{array}{l}\text { Genomförande och } \\
\text { dokumentation av NordMedia } \\
2015 \text { (nordisk forskarkonferens). } \\
\text { Utarbetande och utgivning av } \\
\text { rapporten The Nordic Media } \\
\text { Market } 2015 . \\
\text { Kunskapsförmedling via } \\
\text { webbsidan Medie- och } \\
\text { kommunikationsforskning i } \\
\text { Norden. } \\
\text { Grundläggande dokumentation av } \\
\text { medieutvecklingen i Norden - } \\
\text { marknad, distribution, innehåll, } \\
\text { användning/konsumtion. } \\
\text { Tillhandahålla grundläggande } \\
\text { nordisk forskningsdokumentation } \\
\text { i sökbar databas, baserad på minst } \\
\text { 1000 aktiva forskares forskning. } \\
\text { Deltagande i nationella/ } \\
\text { nordiska/internationella nätverk, } \\
\text { projekt och organisationer inom } \\
\text { området så att datainsamling, och } \\
\text { kunskapsutveckling främjar } \\
\text { kontakterna mellan nordiska } \\
\text { medie-och } \\
\text { kommunikationsforskare och } \\
\text { internationella forskningsmiljöer. }\end{array}$ & $\begin{array}{l}\text { Utgivning av Nordicom Review } \\
\text { som har bidragit till att stärka } \\
\text { dialogen mellan nordiska forskare } \\
\text { och internationellt forskarutbyte. } \\
\text { Utgivning av Nordicom- } \\
\text { information på nordiska språk, } \\
\text { som ytterligare understödjer det } \\
\text { nordiska forskarsamhället. } \\
\text { Samarbete med regionala och } \\
\text { internationella organisationer } \\
\text { enligt särskild översikt med } \\
\text { resultat att Nordisk medie- och } \\
\text { kommunikationsforskning } \\
\text { presenterats i Nordicom och } \\
\text { Nordicom efterfrågas som expert i } \\
\text { en rad globala och europeiska } \\
\text { samarbeten som EU, Unicef, } \\
\text { Unesco, m fl. } \\
\text { Genomförande av } \\
\text { beställningsuppdrag från Nordiska } \\
\text { Ministerrådet till exempel en } \\
\text { utredning om nordisk } \\
\text { kulturstatistik, dokumentationen } \\
\text { av Nordic Gender and Media } \\
\text { Forum samt MIK-arbetet som } \\
\text { fortskred under året. } \\
\text { Resultatet av dessa arbeten är en } \\
\text { förstärkt kunskapsresurs för } \\
\text { kulturpolitiska beslut inom } \\
\text { medieområdet. }\end{array}$ \\
\hline
\end{tabular}

\section{Kunstområdet}

\section{4-2251 Kultur- og Kunstprogrammet}

Programlignende aktiviteter
\begin{tabular}{|l|c|c|c|c|c|} 
Valuta & Budget 2016 & Budget 2015 & Budget 2014 & Disp./bud. 14 & Budget disp. af \\
\hline DKK & 16.240 .000 & 17.786 .000 & 17.523 .000 & $100 \%$ & Sakkunniggruppen
\end{tabular}

Formål

Det nordiske kultur- og kunstprogram har som overordnet mål, at gennem projektbidrag, fremme nye impulser og initiativer på kulturområdet. Programmet skal bidrage til at etablere det nordiske kultur- og kunstsamarbejde som et vigtigt indslag blandt kulturaktører i de nordiske lande, samt i Grønland, Island og på Færøerne, og gøre dette samarbejde synligt i en international sammenhæng.

Från budgetposten förs medel som skal tilldelas Orkester Norden (1.031 TDKK) och Nordisk biblioteksvecka (515 TDKK) till den nya budgetpost Prioriterade verksamheter, 
$4-2232$.

I overensstemmelse med den af MR-K besluttede strategi for 2013-2020 er følgende mål fastlagt for 2016:

\author{
Forvaltnings- Kulturkontakt Nord \\ organ
}

Kontraktperiode Kontraktperiode: 2016

og -status $\quad$ Kontraktstatus: Ny kontrakt 1. januar 2016.

\begin{tabular}{|c|c|c|}
\hline \multicolumn{3}{|l|}{ Mål og resultatopfølgning } \\
\hline 2016 - Mål & 2015 - Mål & 2014 - Opnåede resultater \\
\hline $\begin{array}{l}\text { Give kunstnere og } \\
\text { kulturaktører støtte til kultur- } \\
\text { og kunstproduktioner samt } \\
\text { kreativt arbejde, via } \\
\text { programvirksomhed og } \\
\text { uddeling af midler. } \\
\text { Stimulere til udvikling og } \\
\text { afprøvning af nye ideer, } \\
\text { koncepter og processer. } \\
\text { Etablere nordisk } \\
\text { kultursamarbejde og kunst } \\
\text { som et viktig indslag bland } \\
\text { kulturaktører i Norden og gøre } \\
\text { dette samarbejde synligt i } \\
\text { internationalle sammanhæng. } \\
\text { Stimulera og støtte samarbejde } \\
\text { mellan de nordiska lande og } \\
\text { resten af verden. } \\
\text { Bidrage til at realisere } \\
\text { kulturministrenes strategi for } \\
\text { det nordiske kultursamarbejde } \\
\text { 2013-2020. }\end{array}$ & $\begin{array}{l}\text { Give kunstnere og kulturaktører } \\
\text { støtte til kultur- og } \\
\text { kunstproduktioner samt kreativt } \\
\text { arbejde, via programvirksomhed } \\
\text { og uddeling af midler. } \\
\text { Stimulere til udvikling og } \\
\text { afprøvning af nye ideer, } \\
\text { koncepter og processer. } \\
\text { At de støttede projekter bidrager } \\
\text { til at realisere kulturministrenes } \\
\text { strategi for det nordiske } \\
\text { kultursamarbejde 2013-2020 } \\
\text { Videreudvikle metoder til at } \\
\text { måle effekterne programmet }\end{array}$ & $\begin{array}{l}\text { Kultur- og kunstprogrammet har i } \\
2014 \text { uddelt støtte for i alt } 2169214 \\
€ \text { fordelt på } 86 \text { projekter. I } \\
\text { programmet er brugen af kulturmidler } \\
\text { optimeret, så flest mulige midler går } \\
\text { til programmets vigtigste mål: } \\
\text { realisering af nye nordiske initiativer. } \\
\text { For støttemodtagere er Kultur- og } \\
\text { Kunstprogrammet en mulighed at } \\
\text { prøve nye metoder, genrer og } \\
\text { konstellationer. Effekten er at } \\
\text { kompetencer og kunstneriske udtryk } \\
\text { spredes, nye opstår og nordiske } \\
\text { netværk inden for kultursektoren } \\
\text { etableres og udvikles. } \\
\text { Gennemgangen af de støttede } \\
\text { projekter i programmet i } 2014 \text { viser, } \\
\text { at de fem temaer fra } \\
\text { kulturministrenes strategi indgår } \\
\text { som naturlige elementer i de fleste } \\
\text { støttede projekter med følgende } \\
\text { procentuelle andel: bæredygtighed } 38 \\
\text { \%, kreativitet } 79 \% \text {, interkultur } 72 \text { \%, } \\
\text { børn og unge } 53 \% \text { og digitalisering } \\
35 \% \text {. }\end{array}$ \\
\hline
\end{tabular}

Målene for 2016 skal hovedsagligt nås ved at udbyde ansøgningsrunder og behandle indkomne ansøgninger, arrangere informationsmøder for at stimulere til nye og gode ansøgninger/projekter og informere om programmets muligheder og dets resultater via forskellige informationskanaler.

\title{
4-2253 Nordisk oversættelsesstøtte
}

Programlignende aktiviteter

\begin{tabular}{|l|c|c|c|c|c|} 
Valuta & Budget 2016 & Budget 2015 & Budget 2014 & Disp./bud. 14 & Budget disp. af \\
\hline DKK & 3.067 .000 & 3.067 .000 & 3.022 .000 & $100 \%$ & Sakkunniggruppen
\end{tabular}


Formål

Stödordningens syfte är att bidra till flera utgivningar av nordisk kvalitetslitteratur på andra nordiska språk än originalspråket (danska, färöiska, finska, grönländska, isländska, norska, samiska, svenska). Genom nationell förankring av ordningen i ett nordiskt och internationellt nätverk, skall ordningen sörja för utvecklingen och distributionen av den översatta nordiska litteraturen.

I överensstämmelse med den av MR-K beslutade strategin för 2013-2020 är följande mål beslutade för 2016 .

Kontraktperiode Kontraktsperiod: 2015

og -status $\quad$ Kontraktstatus: Ny kontrakt 1. januar 2016.

\begin{tabular}{|c|c|c|}
\hline \multicolumn{3}{|l|}{ Mål og resultatopfølgning } \\
\hline 2016 - Mål & 2015 - Mål & 2014 - Opnåede resultater \\
\hline $\begin{array}{l}\text { Nordiskt översättningsstöd ska } \\
\text { bidra till att öka kunskapen om } \\
\text { nordisk litteratur i de nordiska } \\
\text { länderna och att öka tillgången } \\
\text { till nordisk litteratur på } \\
\text { medborgarnas egna språk. } \\
\text { Målsättningen är även att stödet } \\
\text { ska skapa ett grundlag för } \\
\text { utväxling för författare i de } \\
\text { nordiska länderna i samband med } \\
\text { utgivningar, uppläsningar, } \\
\text { arrangemang som är kopplade till } \\
\text { presentation av verk som är } \\
\text { nominerade till Nordiska rådets } \\
\text { litteraturpriser och } \\
\text { festivalarrangemang. } \\
\text { Översättning av nordisk barn- } \\
\text { och ungdomslitteratur ska } \\
\text { prioriteras. }\end{array}$ & $\begin{array}{l}\text { Nordiskt översättningsstöd ska } \\
\text { bidra till att öka kunskapen om } \\
\text { nordisk litteratur i de nordiska } \\
\text { länderna och att öka tillgången } \\
\text { till nordisk litteratur på } \\
\text { medborgarnas egna språk. } \\
\text { Målsättningen är även att stödet } \\
\text { ska skapa ett grundlag för } \\
\text { utväxling för författare i de } \\
\text { nordiska länderna i samband med } \\
\text { utgivningar, uppläsningar, } \\
\text { arrangemang som är kopplade till } \\
\text { presentation av verk som är } \\
\text { nominerade till Nordiska rådets } \\
\text { litteraturpriser och } \\
\text { festivalarrangemang. } \\
\text { Översättning av nordisk barn- } \\
\text { och ungdomslitteratur ska } \\
\text { prioriteras. }\end{array}$ & $\begin{array}{l}\text { Også i } 2014 \text { blev den nordiske } \\
\text { oversættelsesstøtte uddelt til } \\
\text { fulde. } \\
\text { Der er fortsat stor søgning til de } \\
\text { finske (som skal dække både } \\
\text { finsk og finlandssvensk), norske } \\
\text { og svenske midler, og Island og } \\
\text { Danmark har oplevet en stigning } \\
\text { i antallet. } \\
\text { Der er i } 2014 \text { i alt blevet } \\
\text { modtaget } 206 \text { ansøgninger, } \\
\text { hvoraf } 171 \text { er blevet } \\
\text { imødekommet inden for de } \\
\text { litterære genrer, som den } \\
\text { nordiske oversættelsesstøtte } \\
\text { dækker. De imødekomne } \\
\text { ansøgninger fordeler sig med } 44 \\
\text { inden for børne- og } \\
\text { ungdomslitteratur, } 110 \text { inden for } \\
\text { skønlitteratur og } 17 \text { inden for } \\
\text { faglitteratur. } \\
\text { Ansøgninger vedr. børne- og } \\
\text { ungdomslitteraturen har oplevet } \\
\text { en lille fremgang, og der ydes } \\
\text { tilskud til feltet med mere end det } \\
\text { dobbelte beløb af den } \\
\varnothing \text { remærkede sum til formålet. } \\
\text { De nominerede og vindende } \\
\text { værker i Nordisk Råds } \\
\text { litteraturpriser har en god } \\
\text { placering i tildelingslisterne, } \\
\text { hvilket vidner om, at der er } \\
\text { succes med udbredelse af titlerne } \\
\text { i Norden. }\end{array}$ \\
\hline
\end{tabular}

Målsättningarna för 2015 och 2016 uppnås genom att profilera stödet i litteraturnätverk, på mässor och konferenser o.dyl. 
4-2254 Nordiskt-baltiskt mobilitetsprogram för Kultur

Programlignende aktiviteter
\begin{tabular}{|l|c|c|c|c|c|} 
Valuta & Budget 2016 & Budget 2015 & Budget 2014 & Disp./bud. 14 & Budget disp. af \\
\hline DKK & 11.429 .000 & 12.357 .000 & 12.174 .000 & $100 \%$ & Sakkunniggruppen
\end{tabular}

Formål

Det Nordisk-baltiska Mobilitetsprogrammet för kultur beviljar stöd till konstnärer och kulturaktörer för att de ska kunna arbeta tillsammans och skapa nya nätverk tvärs över gränserna i regionen.

Från budgetposten förs medel som skal tilldelas Skandinavisk Forenings Kunsterhus i Rom (928 TDKK) till den nya budgetpost Prioriterade verksamheter, 4-2232.

I overensstemmelse med den af MR-K besluttede strategi for 2013-2020 er følgende mål fastlagt for 2016:

Forvaltnings- Kulturkontakt Nord organ

Kontraktperiode Kontraktsperiod: 2016

og -status $\quad$ Kontraktstatus: Ny kontrakt 1. januar 2016.

\begin{tabular}{|c|c|c|}
\hline \multicolumn{3}{|l|}{ Mål og resultatopfølgning } \\
\hline 2016 - Mål & 2015 - Mål & 2014 - Opnåede resultater \\
\hline $\begin{array}{l}\text { Programmet skal forstærke } \\
\text { mulighederne for kulturelt og } \\
\text { kunstnerisk samarbejde i de } \\
\text { nordiske og baltiske regioner } \\
\text { gennem øgede kontakter og nye } \\
\text { netværk, samt at fremme nye } \\
\text { impulser og initiativer på } \\
\text { kulturområdet bland lokale, } \\
\text { nationale, regionale } \\
\text { og internationale aktører, } \\
\text { organisationer og institutioner. } \\
\text { Dette skal ske via netværksstøtte, } \\
\text { støtte til mobilitet og } \\
\text { kunstnerresidenser. } \\
\text { Endelig skal programmet/det } \\
\text { nordisk-baltiske } \\
\text { kultursamarbejde blive mere } \\
\text { kendt i regionen og internationalt. }\end{array}$ & $\begin{array}{l}\text { Programmet skal forstærke } \\
\text { mulighederne for kulturelt og } \\
\text { kunstnerisk samarbejde i de } \\
\text { nordiske og baltiske regioner } \\
\text { gennem øgede kontakter og nye } \\
\text { netværk, samt at fremme nye } \\
\text { impulser og initiativer på } \\
\text { kulturområdet bland lokale, } \\
\text { nationale, regionale og } \\
\text { internationale aktører, } \\
\text { organisationer og institutioner. } \\
\text { Dette skal ske via netværksstøtte, } \\
\text { støtte til mobilitet og } \\
\text { kunstnerresidenser. } \\
\text { Endelig skal det programmet/det } \\
\text { nordisk-baltiske } \\
\text { kultursamarbejde blive mere } \\
\text { kendt i regionen og internationalt }\end{array}$ & $\begin{array}{l}\text { Nordisk Baltisk } \\
\text { Mobilitetsprogram Kultur- og } \\
\text { kunstprogrammet har i } 2014 \\
\text { uddelt støtte for i alt } 1687381 € \\
\text { fordelt på } 383 \text { projekter. } \\
\text { Mobilitetsstøtte giver de rejsende } \\
\text { kunstnere og kulturaktører et } \\
\text { markant udbytte af støtten, bl.a. i } \\
\text { form af nye netværk, kontakter, } \\
\text { inspiration, udvikling og viden. } \\
\text { Netværksstøtten øger helt konkret } \\
\text { nye samarbejdsformer og } \\
\text { partnerskab mellem individer og } \\
\text { organisationer indenfor og på } \\
\text { tværs af kunst- og kulturfelterne i } \\
\text { de nordiske og baltiske lande. } \\
\text { Støtte til Residenscentre giver } \\
\text { plads til eksperimenter, nye } \\
\text { møder, samarbejder og } \\
\text { inspiration. } \\
\text { Kulturkontakt Nord har } \\
\text { gennemgået alle områder af sit } \\
\text { arbejde omkring programmerne, } \\
\text { så vurdering af effekten tages } \\
\text { med i alle led af } \\
\text { programadministration. }\end{array}$ \\
\hline
\end{tabular}




\begin{tabular}{|l|l|l|}
\hline & & $\begin{array}{l}\text { Effekterne søges illustreret i den } \\
\text { løbende } \\
\text { kommunikationsvirksomhed, } \\
\text { herunder i årsrapporten. }\end{array}$ \\
\hline
\end{tabular}

Mål for 2016 skal hovedsagligt nås ved at udbyde ansøgningsrunder og behandle indkomne ansøgninger, arrangere informationsmøder for at stimulere til nye og gode ansøgninger/projekter og informere om programmets muligheder og dets resultater via forskellige informationskanaler.

Finansiering af programmet sker ligeværdigt med bidrag fra de baltiske lande og Nordisk Ministerråd.

Dertil tildeles programmet et bidrag fra MR-SAM (internationalt samarbejde).

\section{Nordiske Kulturhus}

\section{4-2270 Nordens hus i Reykjavik}

Institution
\begin{tabular}{|l|c|c|c|c|c|} 
Valuta & Budget 2016 & Budget 2015 & Budget 2014 & NMR fin. 14 & Budget disp. af \\
\hline ISK & 189.088 .000 & 189.088 .000 & 182.870 .000 & $89 \%$ & Institutionen \\
\hline Modsv. DKK & 8.887 .000 & 8.887 .000 & 8.412 .000 & &
\end{tabular}

Nordens hus i Reykjavik er også sekretariat for litteraturprisen og børne- og ungdomslitteraturprisen (deler af budgetpost 4-2206). Desuden er der bevilling fra budgetpost 4-2208, Løftet for børne- og ungdomslitteratur. Nordens hus i Reykjavik er forvaltningsorgan for en del af budgetpost 1-1012, Norden i Fokus.

Formål Nordens hus i Reykjavik (Norey) har som særlig opgave at fungere som bindeled mellem Island og det øvrige Norden med hensyn til at aktivere og stimulere den nordiske interesse i Island og formidle viden om Island til de øvrige nordiske lande.

I overensstemmelse med den af MR-K besluttede strategi er følgende mål fastlagt for 2016:

Kontraktperiode Kontraktsperiod 2014-2016

og -status $\quad$ Kontraktstatus: Ny kontrakt 1. januar 2017.

\begin{tabular}{|c|c|c|}
\hline \multicolumn{3}{|l|}{ Mål og resultatopfølgning } \\
\hline 2016 - Mål & 2015 - Mål & 2014 - Opnåede resultater \\
\hline $\begin{array}{l}\text { I } 2016 \text { er det målet at finde } \\
\text { finansiering til at kunne } \\
\text { påbegynde en omfattende og } \\
\text { tiltrængt renovering af Nordens } \\
\text { Hus som er en fredet bygning } \\
\text { samt landskabet omkring huset. } \\
\text { Renoveringen vil stå på i ca. } 2 \\
\text { år og vil i perioder påvirke } \\
\text { husets drift og aktiviteter. } \\
\text { Der vil værre færre men større } \\
\text { udstillinger, målet er } 3 \\
\text { udstillinger, der etableres med } \\
\text { internationale } \\
\text { samarbejdspartnere. }\end{array}$ & $\begin{array}{l}\text { LITTERATUR: I } 2015 \text { øges fokus } \\
\text { på litteratur som et naturligt } \\
\text { omdrejningspunkt for Nordens } \\
\text { Hus. Huset vil danne ramme for } \\
\text { Reykjavik Litteraturfestival, } \\
\text { International writers retreat, Hygge } \\
\text { factorys skriveworkshops for } \\
\text { udsatte unge, en ny serie højt } \\
\text { profilerede månedlige } \\
\text { forfatteraftener fra efteråret, } \\
\text { præsentation af de nominerede } \\
\text { forfattere til Nordisk Råds } \\
\text { Litteraturpris, etablering af } \\
\text { læseklubber og streaming af } \\
\text { litterære arrangementer fra huset. }\end{array}$ & $\begin{array}{l}\text { I } 2014 \text { har Nordens Hus opnået } \\
\text { sine mål om at producere og } \\
\text { formidle kulturelle begivenheder } \\
\text { af høj kvalitet samt fortsat at } \\
\text { udvikle huset som et forum for } \\
\text { nordisk kultur. Der har været lagt } \\
\text { vægt på børne- og } \\
\text { ungdomsprogrammer, blandt } \\
\text { andet med børnelitteratur- } \\
\text { festivalen ”Myrin” og en } \\
\text { interaktiv udstilling med } \\
\text { forbindelse til Nordisk Råds } \\
\text { børne- og ungdomslitteraturpris. } \\
\text { Udstillingen var yderst velbesøgt } \\
\text { både af skoleklasser og familier. }\end{array}$ \\
\hline
\end{tabular}




\begin{tabular}{|c|c|c|}
\hline $\begin{array}{l}\text { ke samarbejde. } \\
\text { t aktiv deltagelse i } \\
\text { ationale festivaler og }\end{array}$ & $\begin{array}{l}\text { Biblioteket forventes at afslutte } \\
\text { registreringen af alle bøger i } \\
\text { Gegnir, hvilket er med til at øge } \\
\text { antallet af udlån. } \\
\text { FILM: I samarbejde med de } \\
\text { Nordiske ambassader præsenteres i } \\
\text { foråret Nordisk Filmfestival og } \\
\text { RIFF vil igen i år også være en } \\
\text { samarbejdspartner som inddrager } \\
\text { hele huset i seminarer og events } \\
\text { under den meget velbesøgte } \\
\text { filmfestival. } \\
\text { SAMFUND: I juni måned indfører } \\
\text { vi den nordiske tradition med } \\
\text { politiske sommermøder i Island. } \\
\text { Over } 3 \text { dage vil huset og de } \\
\text { nærmeste omgivelser blive } \\
\text { inddraget i en stor politisk festival } \\
\text { med deltagelse af alle politiske } \\
\text { partier, medier og NGO’er. } \\
\text { BøRN \& UNGE: inddrages i } \\
\text { litteraturen, dels i samarbejde med } \\
\text { Hygge Factory, dels i forbindelse } \\
\text { med Børne og } \\
\text { Ungdomslitteraturprisen. Både } \\
\text { forår og efterår vil huset modtage } \\
\text { skoleklasser fra hele Island, som } \\
\text { indføres i det nordiske samarbejde } \\
\text { og nordisk litteratur. } \\
\text { UDSTILLINGER: Weather } \\
\text { Diaries rejser videre ud i verden og } \\
\text { er således en fornem eksponent for } \\
\text { Vestnordisk kunst og kultur. Huset } \\
\text { præsenterer i årets løb flere } \\
\text { udstillinger med nordisk og } \\
\text { vestnordisk kunst. } \\
\text { MUKITEKTUR i } \\
\text { VERDENSKLASSE: Huset skal } \\
\text { klassisk i Vatnsmyrin sætter fokus } \\
\text { på ny og nordisk musik både forår } \\
\text { og efterår. } \\
\text { SEMINARER: holdes løbende } \\
\text { gennem hele året i samarbejde med } \\
\text { nordiske brancheorganisationer og } \\
\text { universitetet m.fl. }\end{array}$ & $\begin{array}{l}\text { Arbejdet med børne- og ung- } \\
\text { domslitteraturprisen er fortsat, og } \\
\text { i slutningen af } 2014 \text { blev det } \\
\text { offentliggjort, at Nordens Hus } \\
\text { også overtager sekretariatet for } \\
\text { Nordisk Råds Litteraturpris. } \\
\text { Nordens Hus er producent af } \\
\text { udstillingen Weather Diaries, der } \\
\text { åbnede i Frankfurt i 2014, og } \\
\text { derefter gik til København, hvor } \\
\text { den vises i Museet for fotokunst } \\
\text { til marts 2015. Udstillingen } \\
\text { omfatter værker af } 11 \text { designere } \\
\text { fra Island, Færøerne og Grønland } \\
\text { og lægger således vægt på det } \\
\text { unikke Vestnorden. Mange andre } \\
\text { aktiviteter er blevet gennemført i } \\
\text { Nordens Hus i } 2014 \text { for at nå } \\
\text { målene for huset. Disse omfatter } \\
\text { primært: litterære arrangementer, } \\
\text { seminarer om madspild, } \\
\text { forskellige kulturelle festivaler } \\
\text { med fokus på musik, film og } \\
\text { kunst, udstillinger og } \\
\text { informationsaktiviteter om de } \\
\text { enkelte nordiske lande og } \\
\text { Norden. }\end{array}$ \\
\hline
\end{tabular}


renoveres, og 2015 benyttes til at

fundraise og planlægge de

kommende års hovedrenovering af

huset og landskabet omkring huset.

Målsättningen för 2016 realiseras genom seminarier, konferenser, föreläsningar, konserter, scenkonst, utställningar, filmvisningar m.m.

\section{4-2272 Nordens hus på Färöarna}

Institution
\begin{tabular}{|l|c|c|c|c|c|} 
Valuta & Budget 2016 & Budget 2015 & Budget 2014 & NMR fin. 14 & Budget disp. af \\
\hline DKK & 13.490 .000 & 13.490 .000 & 13.330 .000 & $68 \%$ & Institutionen
\end{tabular}

Nordens hus på Färöarna er også sekretariat for Nordisk Råds Musikpris.

Formål $\quad$ Nordens hus på Färöarna (NLH) har som särskild uppgift att förmedla nordisk kultur till Färöarna och färöisk kultur till det övriga Norden samt att främja och stödja det färöiska kulturlivet.

I overensstemmelse med den af MR-K besluttede strategi for 2013-2020 er følgende mål fastlagt for 2016:

Kontraktperiode Kontraktsperiod 2015-2017

og -status $\quad$ Kontraktstatus: Ny kontrakt 1. januar 2018.

\begin{tabular}{|c|c|c|}
\hline \multicolumn{3}{|l|}{ Mål og resultatopfølgnin } \\
\hline 2016 - Mål & Mål & de resultater \\
\hline $\begin{array}{l}\text { Det er NLH's mission at være et } \\
\text { nordisk kulturcenter og en kreativ } \\
\text { mødeplads. Det er NLH’s vision } \\
\text { at være en aktiv og relevant } \\
\text { kulturinstitution med en } \\
\text { mangfoldig programvirksomhed } \\
\text { som henvender sig til en bred } \\
\text { interesse- og aldersgruppe. } \\
\text { Nordens Hus overordnede } \\
\text { strategi med hensyn til program } \\
\text { er at programmet skal indeholde } \\
\text { en vel balanceret blanding af } \\
\text { store profileringsarrangementer, } \\
\text { som produceres af Nordens Hus, } \\
\text { mindre events, som gentages } \\
\text { regelmæssigt og arrangementer } \\
\text { som er initieret af andre end } \\
\text { Nordens Hus, men lever op til } \\
\text { institutionens kvalitetskrav. } \\
\text { Et af de principper der arbejdes } \\
\text { med i husets program er at få det } \\
\text { meste ud af hvert arrangement, } \\
\text { og målet er at koble besøgende } \\
\text { udenlandske kunstnere til deres }\end{array}$ & $\begin{array}{l}\text { Nordens hus på Færøerne skal } \\
\text { formidle nordisk kultur til } \\
\text { Færøerne og færøsk kultur til } \\
\text { norden, samt støtte det færøske } \\
\text { kulturliv i samarbejde med andre } \\
\text { færøske kulturaktører. } \\
\text { NLH vil i samarbejde med } \\
\text { Kulturministeriet, Tórshavnar } \\
\text { Kommune og Atlantic Airways } \\
\text { afprøve projektet ”Loftbro” som } \\
\text { har som mål at støtte færøske } \\
\text { kunstnere til at nå til et bredere } \\
\text { publikum end det færøske. } \\
\text { Projektet bliver evalueret hen } \\
\text { imod slutningen af året og en } \\
\text { beslutning taget om fortsættelsen. } \\
\text { Nordens hus vil fortsætte med at } \\
\text { prioritere børne- og } \\
\text { ungdomskultur med festivaler, } \\
\text { musik konkurrence, } \\
\text { sideprogrammer til børn og unge } \\
\text { som del af alle større } \\
\text { arrangementer og NLH vil } \\
\text { oprette et rådgivende }\end{array}$ & $\begin{array}{l}\text { Året } 2014 \text { tog, udgangspunkt i } \\
\text { mål og resultatkontrakten samt i } \\
\text { ministerrådets nye strategi for det } \\
\text { nordiske kultursamarbejde, } \\
\text { herunder. } \\
\text { I } 2014 \text { blev der afprøvet nogle } \\
\text { nye arrangementer og aktiviteter, } \\
\text { herunder “Land í eygsjón”, en } \\
\text { kulturfestival som fokuserer på et } \\
\text { af de nordiske lande og giver } \\
\text { mulighed for fordybelse i dets } \\
\text { kunst og kultur og } \\
\text { Børnekulturfestivalen, som blev } \\
\text { afholdt for første gang i april } \\
\text { 2014, varede en uge og overtog } \\
\text { hele huset med arrangementer til } \\
\text { børn, med børn og af børn. Året } \\
\text { resulterede i over } 400 \\
\text { arrangementer med knap } 60.000 \\
\text { besøgende, som er en lille } \\
\text { stigning fra } 2013 \text {. } \\
\text { Nordens Hus overordnede } \\
\text { strategi med hensyn til mål- og } \\
\text { resultatkontrakt var, ligesom i }\end{array}$ \\
\hline
\end{tabular}




\begin{tabular}{|c|c|c|}
\hline $\begin{array}{l}\text { kollegaer på Færøerne med håb } \\
\text { om nye netværksdannelser og } \\
\text { muligt fremtidigt samarbejde. } \\
\text { NLH prioriterer børne og } \\
\text { ungdomskultur, både med } \\
\text { særskilte arrangementer og med } \\
\text { at der til alle større arrangementer } \\
\text { i huset f.ex. Land í eygsjón, } \\
\text { Vinterjazz, Bókadagar m.m. altid } \\
\text { sideløbende er mindre eller større } \\
\text { arrangementer til børn. }\end{array}$ & $\begin{array}{l}\text { ungdomsråd som kan/skal } \\
\text { bidrage til husets program. } \\
\text { Nordens hus vil fortsætte med } \\
\text { projektet ’Land í eygsjón” hvor } \\
\text { der fokuseres på et enkelt af de } \\
\text { nordiske lande som giver } \\
\text { mulighed for fordybelse. Nordens } \\
\text { hus vil sætte nordisk samarbejde } \\
\text { på spidsen i det vestnordiske } \\
\text { projekt The Big Borealis Band, } \\
\text { med udstillingen The Weather } \\
\text { Diaries og med turneringen af } \\
\text { NLH’s udstilling Gisp! til } \\
\text { Danmark, Finland og Åland. } \\
\text { NLH skal fungere som Nordisk } \\
\text { Ministerråds synlige brohoved og } \\
\text { idet sikre at lokale kunstnere } \\
\text { m.fl. informeres og støttes i } \\
\text { forbindelse med udarbejdelse af } \\
\text { ansøgninger til bl.a. Nordisk } \\
\text { kulturfond og NMR’s kultur- og } \\
\text { kunstprogram. NLH er } \\
\text { sekretariat for Nordisk Råds } \\
\text { Musikpris. }\end{array}$ & $\begin{array}{l}\text { 2013, at programmet skulle } \\
\text { indeholde en vel balanceret } \\
\text { blanding af store } \\
\text { profileringsarrangementer } \\
\text { produceret af Nordens Hus, } \\
\text { mindre gentagende events som } \\
\text { f.eks. filmaftener, kulturcaféer, } \\
\text { workshops produceret af Nordens } \\
\text { Hus eller som } \\
\text { samarbejdsprojekter med andre } \\
\text { institutioner, foreninger m.m. } \\
\text { Programmet levede op til dette. } \\
\text { Endelig var der også plads til } \\
\text { arrangementer som var initieret af } \\
\text { andre end Nordens Hus, men } \\
\text { levede op til institutionens } \\
\text { kvalitetskrav. }\end{array}$ \\
\hline
\end{tabular}

Målsättningen realiseras genom seminarier, konferenser, föreläsningar, konserter, scenkonst, utställningar, filmvisningar mm.

\section{4-2274 Nordens Institut på Åland}

\section{Institution}

\begin{tabular}{|l|c|c|c|c|c|} 
Valuta & Budget 2016 & Budget 2015 & Budget 2014 & NMR fin. 14 & Budget disp. af \\
\hline EUR & 394.700 & 394.700 & 388.100 & $77 \%$ & Institutionen \\
\hline Modsv. DKK & 2.944 .000 & 2.944 .000 & 2.895 .000 & &
\end{tabular}

Formål Nordens institut på Åland (NIPÅ) har som överordnat mål att främja det åländska kulturlivet och fungera som en länk mellan Åland och det övriga Norden. Institutionen skall stimulera de nordiska intressena på Åland och förmedla kunskap om Åland till övriga Norden.

I överenstämmelse med Nordiska ministerrådets strategi för det nordiska kultursamarbetet 2013-2020 kommer NIPÅ arbeta utifrån tre målområden i 2016: 1) Barn och unga på Åland och i Norden 2) Digitala plattformar, kommunikation och förmedling och 3) Åland som interkulturell knutpunkt.

Kontraktperiode Kontraktsperiod 2015-2017 og -status 


\begin{tabular}{|c|c|c|}
\hline \multicolumn{3}{|l|}{ Mål og resultatopfølgning } \\
\hline 2016 - Mål & 2015 - Mål & 2014 - Opnåede resultater \\
\hline 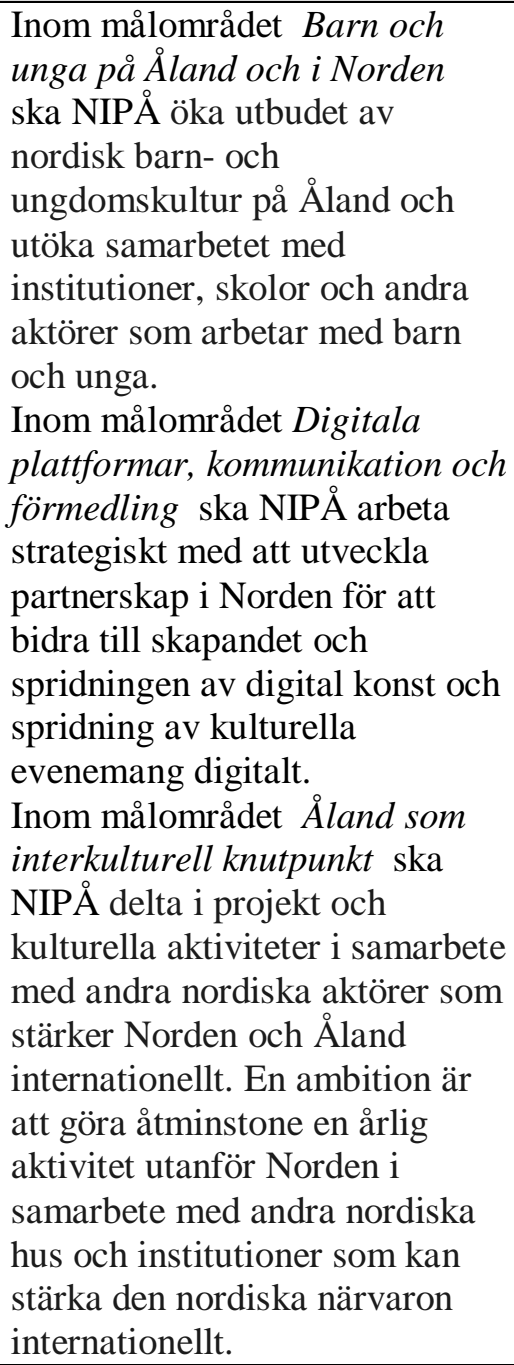 & $\begin{array}{l}\text { Nordens Institut på Åland har } \\
\text { som målsättning att främja det } \\
\text { åländska kulturlivet i samspel } \\
\text { med kulturlivet i det övriga } \\
\text { Norden och i samarbete med } \\
\text { lokala kulturorganisationer. } \\
\text { NIPÅ ska genom information } \\
\text { och rådgivning arbeta för att } \\
\text { lokala kulturaktörer får ökad } \\
\text { kunskap om Nordiska } \\
\text { ministerrådets kulturprogram. } \\
\text { Målet är att genomföra ett } \\
\text { gemensamt Nordisk projekt som } \\
\text { ska realiseras utanför Norden i } \\
\text { samarbete med de andra } \\
\text { nordiska kulturinstitutionerna } \\
\text { som ett led i strategin för } \\
\text { profilering och positionering av } \\
\text { Norden. }\end{array}$ & 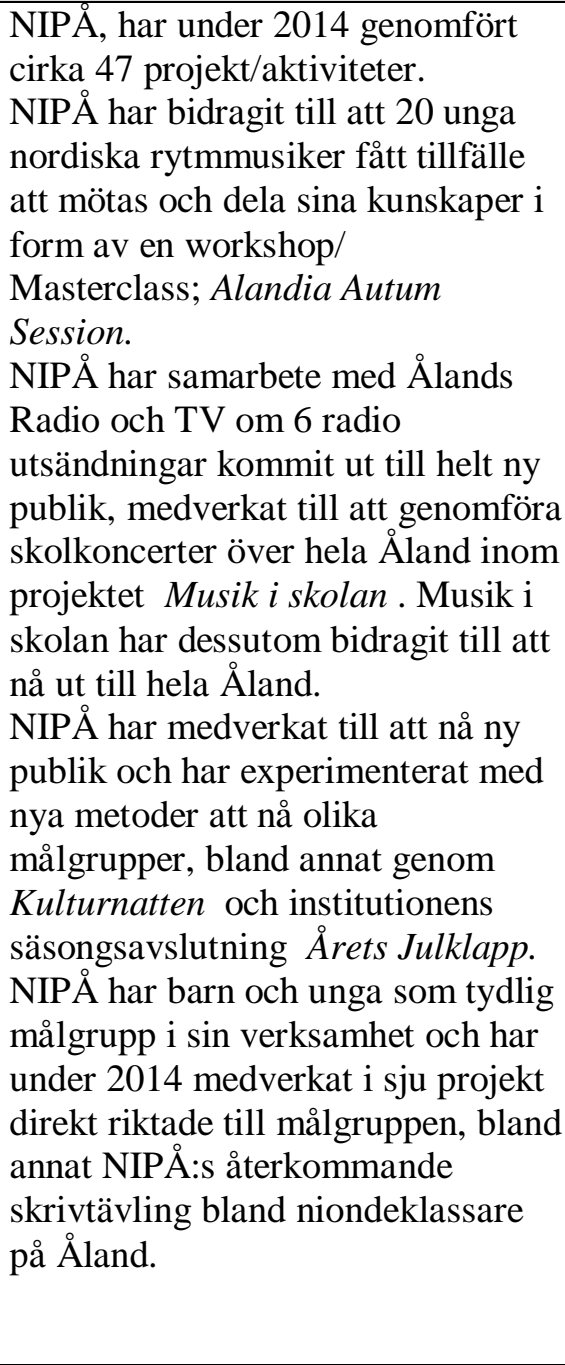 \\
\hline
\end{tabular}

Målen realiseras genom konsertverksamhet, utställningar, digital förmedling, barn- och ungdomsprojekt, utbyten och samarbeten med kulturinstitutioner i övriga Norden.

\section{4-2277 Nordens Institut på Grönland (NAPA)}

Institution
\begin{tabular}{|l|c|c|c|c|c|} 
Valuta & Budget $\mathbf{2 0 1 6}$ & Budget $\mathbf{2 0 1 5}$ & Budget $\mathbf{2 0 1 4}$ & NMR fin. 14 & Budget disp. af \\
\hline DKK & 6.322 .000 & 6.322 .000 & 6.247 .000 & $89 \%$ & Institutionen
\end{tabular}
NAPA`s styrelse ha dispositionsrätt över institutionens fondmedel som består av cirka 4 miljoner DKK årligen.
Utbetalade medel per år varierar beroende på antalet ansökningar och dess kvalitet.
NAPA er forvaltningsorgan for Hallo Norden i Grönland.

Formål Nordens institut på Grönland (NAPA) har som uppgift att öka kunskapen om Norden och det nordiska samarbetet i Grönland. Institutionens specifika uppgifter är; att stötta, stimulera och bidra till att utveckla det grönländska kulturlivet, med särskild vikt på barn- och ungdomskultur, att upplysa Grönland om det övriga Norden, att vara ett länk avseende kultur och information mellan Grönland och de andra nordiska länderna 
samt Färöarna och Åland, att stötta och stimulera de nordiska intressena på Grönland. Institutionen har en egen ansökningsfond med syfte att utveckla, stödja och stimulera det grönländska och nordiska kulturlivet, med särskild betoning på barn och unga. Utbetalade medel per år varierar beroende på ansökningarnas kvalitet.

I överenstämmelse med Nordiska ministerrådets strategi för det nordiska kultursamarbetet 2013-2020 kommer NAPA arbeta utifrån tre målområden i 2016: 1) Det unga Norden, 2) Det interkulturella Norden och 3) Det hållbara Norden.

Kontraktperiode Kontraktsperiod 2015-2017 og -status

\begin{tabular}{|c|c|c|}
\hline \multicolumn{3}{|l|}{ Mål og resultatopfølgning } \\
\hline 2016 - Mål & 2015 - Mål & 2014 - Opnåede resultater \\
\hline $\begin{array}{l}\text { Inom målområdet Det unga } \\
\text { Norden ska NAPA prioritera } \\
\text { projekt initierade av unga, } \\
\text { genomföra verksamheter där } \\
\text { unga bereds möjlighet att } \\
\text { medverka och delta och skaffa } \\
\text { sig erfarenhet av konst och } \\
\text { kulturverksamhet i syfte att } \\
\text { inspirera till egna initiativ samt } \\
\text { att genom kulturprojekt verka för } \\
\text { att barn och unga inkluderas och } \\
\text { bereds utrymme i kultur och } \\
\text { samhällsliv. } \\
\text { Inom målområdet Det } \\
\text { interkulturella Norden ska NAPA } \\
\text { genomföra minst en } \\
\text { sektorsspecifik konferens om året } \\
\text { i syfte att stärka nätverk, } \\
\text { säkerställa kunskapsöverföring } \\
\text { och identifiera nya utmaningar } \\
\text { samt vara en aktiv part på minst } \\
\text { två nordiska mötesplatser och } \\
\text { företräda grönländskt konst och } \\
\text { kulturliv. NAPA ska dessutom } \\
\text { spela en central roll i arbetet med } \\
\text { Arctic Winter Games } 2016 \text { och } \\
\text { arrangemangets kulturprogram. } \\
\text { Inom målområdet Det hållbara } \\
\text { Norden ska NAPA prioritera } \\
\text { projekt som försöker motverka } \\
\text { olika tillgänglighetsproblem, } \\
\text { NAPA skall genom sina } \\
\text { prioriteringar kompensera för de } \\
\text { särskilda logistiska utmaningar } \\
\text { som det grönländska kulturlivet } \\
\text { har. }\end{array}$ & $\begin{array}{l}\text { NAPA ska vara en synlig aktör } \\
\text { på den grönländska och nordiska } \\
\text { konst- och kulturscenen, både } \\
\text { som producent, samarbetspartner } \\
\text { och mentor. NAPA ska bidra till } \\
\text { att bevara det grönländska } \\
\text { kulturarvet och ska i det arbetet } \\
\text { samarbeta med grönländska och } \\
\text { nordiska kulturaraktörer. NAPA } \\
\text { ska prioritera verksamheter för } \\
\text { och av barn och unga. NAPA ska } \\
\text { genom information och } \\
\text { rådgivning arbeta för att lokala } \\
\text { kulturaktörer får ökad kunskap } \\
\text { om Nordiska ministerrådets } \\
\text { kulturprogram. Ytterligare } \\
\text { målsättning är att genom } \\
\text { gemensamma projekt utveckla } \\
\text { samarbetet med de övriga } \\
\text { nordiska husen och instituten. } \\
\text { NAPA ska etablera ett Hallå } \\
\text { Norden kontor. } \\
\text { NAPA:s fondmedel syftar till att } \\
\text { stödja det grönländska och det } \\
\text { nordiska kulturlivet genom } \\
\text { resestöd och projektstöd. NAPA:s } \\
\text { styrelse ansvarar för utlysning, } \\
\text { behandling och beslut av } \\
\text { ansökningarna till NAPA:s } \\
\text { fondmedel som består av cirka } 4 \\
\text { miljoner DKK årligen. Summan } \\
\text { varierar från år till år beroende på } \\
\text { antalet ansökningar och dess } \\
\text { kvalitet. }\end{array}$ & $\begin{array}{l}\text { NAPA har tagit ansvar för } \\
\text { produktionen av det grönländska } \\
\text { kulturinslaget under Artic Winter } \\
\text { Games, AWG. Genom } \\
\text { medverkan i AWG har NAPA } \\
\text { medverkat till att ge de unga } \\
\text { deltagarna erfarenheter som } \\
\text { stöttar deras eget kreativa } \\
\text { skapande och utveckling. } \\
\text { NAPA har bidragit till samarbetet } \\
\text { mellan de nordiska } \\
\text { kulturskoleorganisationerna } \\
\text { genom att arrangera en konferens } \\
\text { om barn och ungas rätt till } \\
\text { kulturutövande. } \\
\text { Under 2013 arrangerade NAPA } \\
\text { fotoutställningen Gay Greenland } \\
\text { som under 2014 fortsatt att } \\
\text { turnera. Utställningen är den } \\
\text { första visuella dokumentationen } \\
\text { som sätter fokus på } \\
\text { homosexualitet på Grönland. } \\
\text { NAPA har återigen bidragit till } \\
\text { att främja barn och ungas } \\
\text { skapande genom institutionens } \\
\text { novelltävling för unga, Allatta. } \\
\text { NAPA har medverkat till } \\
\text { utställningen Think Eat Save } \\
\text { som turnerat runt Grönland under } \\
\text { 2014. Utställningen gav bland } \\
\text { annat skolelever ett tillfälle att } \\
\text { lära sig om matspill, hushållning } \\
\text { och matlagnings samt möjlighet } \\
\text { att skapa foodwaste-skulpturer. } \\
\text { NAPA har beviljat } 72 \\
\text { ansökningar inom institutionens } \\
\text { egen fond med syfte att utveckla, } \\
\text { stödja och stimulera det } \\
\text { grönländska och nordiska }\end{array}$ \\
\hline
\end{tabular}


NAPA:s fondmedel syftar till att stödja det grönländska och det nordiska kulturlivet genom resestöd och projektstöd. NAPA:s styrelse ansvarar för utlysning, behandling och beslut av ansökningarna till NAPA:s fondmedel som består av cirka 4 miljoner DKK årligen. Summan varierar från år till år beroende på antalet ansökningar och dess kvalitet.

Målen uppnås genom utställningar, barn- och ungdomsprojekt, utbyten och samarbeten med kulturinstitutioner i övriga Norden, projektstöd till nordiska initiativ och projekt med grönländska kulturintressen.

\section{$\underline{4-2548 \text { Kulturkontakt Nord }}$}

\section{Institution}

\begin{tabular}{|l|c|c|c|c|c|} 
Valuta & Budget 2016 & Budget 2015 & Budget 2014 & NMR fin. 14 & Budget disp. af \\
\hline EUR & 1.494 .600 & 1.494 .600 & 1.458 .800 & $93 \%$ & Institutionen \\
\hline Modsv. DKK & 11.150 .000 & 11.150 .000 & 10.883 .000 & &
\end{tabular}

Kulturkontakt Nord er også forvaltningsorgan for programmerne Kultur-og kunstprogrammet (budgetpost 4-2251), Nordiskt-baltiskt mobilitetsprogram för Kultur (4-2254) og NORDBUK (4-2212).

Kulturkontakt Nord er forvaltningsorgan for en del af budgetpost 1-1012, Norden i Fokus.

Formål Formål Kulturkontakt Nord er et administrativt og operativt sekretariat for Nordisk Ministerråds programmer. Kulturkontakt Nord udgør en nordisk mødeplads i Finland med fokus på kulturelle aktiviteter. Kulturkontakt Nord skal profilere det nordisk kultursamarbejde i Norden og internationalt.

I overensstemmelse med den af MR-K besluttede strategi for det nordiske kultursamarbejde 2013-2020 er følgende mål fastlagt for 2016:

Forvaltnings- Kulturkontakt Nord
organ

Kontraktperiode Kontraktperiode: 2014-2016

og -status $\quad$ Kontraktstatus: Gældende kontrakt forlænges med et år til 31.12. 2016.

\begin{tabular}{|c|c|c|}
\hline \multicolumn{3}{|l|}{ Mål og resultatopfølgning } \\
\hline 2016 - Mål & 2015 - Mål & 2014 - Opnåede resultater \\
\hline $\begin{array}{l}\text { KKN skal gennemføre aktiviteter } \\
\text { inden for sine tre } \\
\text { virksomhedsområder; } \\
\text { 1. Sprede viden om og interesse } \\
\text { for nordisk kunst og kultur. } \\
\text { 2. Fungere som sekretariat for tre } \\
\text { nordiske støtteprogrammer: }\end{array}$ & $\begin{array}{l}\text { KKN skal gennemføre aktiviteter } \\
\text { inden for sine tre } \\
\text { virksomhedsområder; } \\
\text { 1. Sprede viden om og interesse } \\
\text { for nordisk kunst og kultur. } \\
\text { 2. Fungere som sekretariat for tre } \\
\text { nordiske støtteprogrammer: }\end{array}$ & $\begin{array}{l}\text { Kulturkontakt Nord har fungeret } \\
\text { som en central mødesplads og } \\
\text { arrangementerne på kulturcentret } \\
\text { og biblioteket i Helsingfors havde } \\
\text { totalt } 4229 \text { besøgende i } 2014 \text {, } \\
\text { hvilket er næsten } 2000 \text { flere end } \\
\text { året før. På to år er det en }\end{array}$ \\
\hline
\end{tabular}




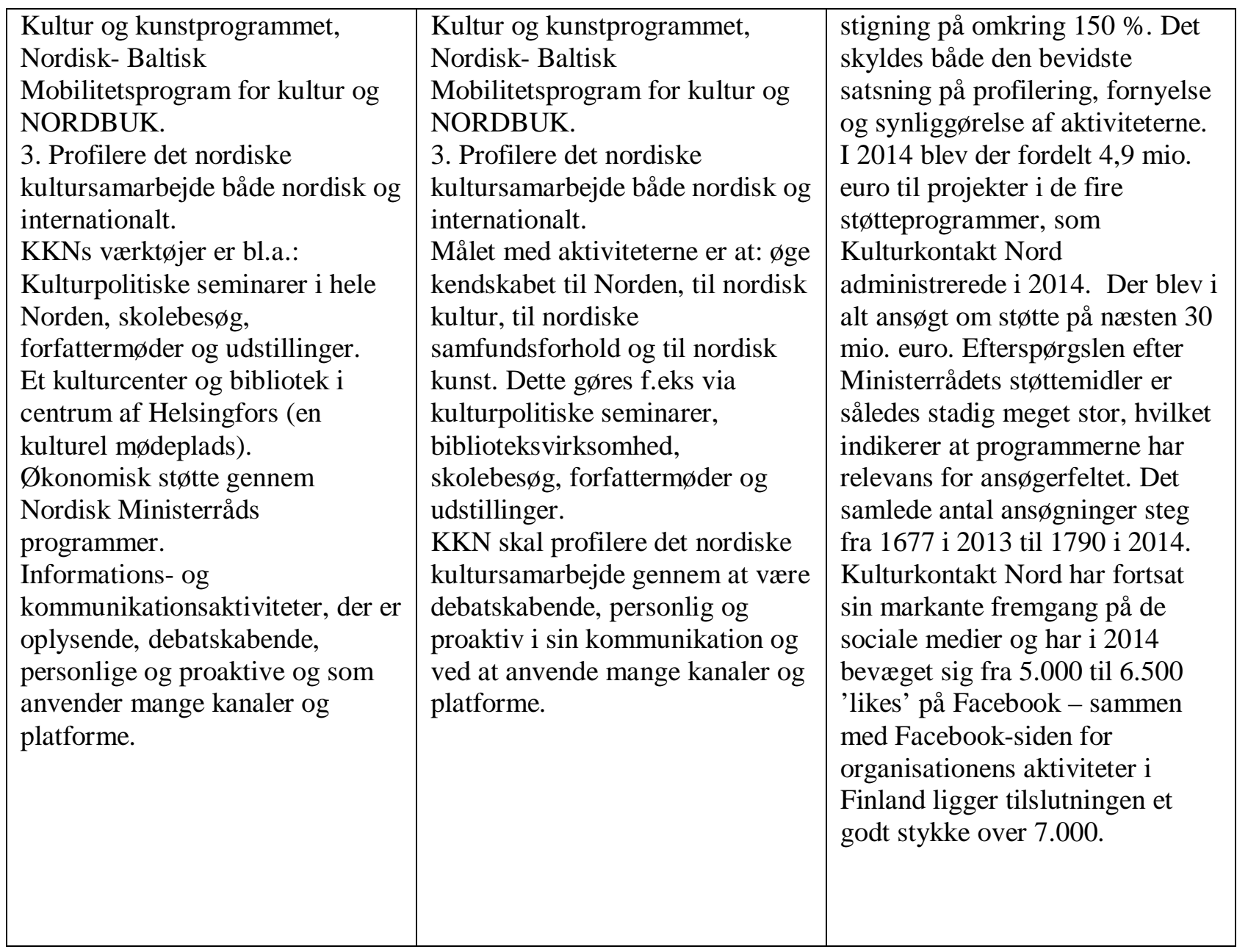

\section{Andra kultursatsningar}

4-2232 Prioriterade verksamheter

Organisationsbidrag

\begin{tabular}{|l|c|c|c|c|c|} 
Valuta & Budget 2016 & Budget 2015 & Budget 2014 & Disp./bud. 14 & Budget disp. af \\
\hline DKK & 2.699 .000 & 0 & 0 & $0 \%$ & MR-K
\end{tabular}

Formål Syftet med den nyupprättade budgetposten är att stödja av MR-K prioriterade verksamheter som var för sig är med och utvecklar det nordiska kultursamarbetet. Verksamheterna är Orkester Norden, Nordisk biblioteksvecka, Skandinavisk Forenings Kunstnerhus i Rom och Debutantseminariet vid Biskops-Arnö.

I overensstemmelse med den af MR-K besluttede strategi for 2013-2020 er følgende mål fastlagt for 2016:

\begin{tabular}{|l|l|l|}
\hline Mål og resultatopfølgning \\
\hline 2016 - Mål & 2015 - Mål & 2014 - Opnåede resultater \\
\hline Skandinavisk Forenings Kunstnerhus i & & \\
\hline
\end{tabular}


Rom tilldelas 928000 DKK i 2015 års priser. Målet med verksamheten under året är:

- att erbjuda konstnärer inom alla konstområden ett väl fungerande residensuppehåll med service, individuell rådgivning, nätverksuppbyggning och goda arbetsmöjligheter

- att förmedla kontakt mellan nordisk och italiensk kultur genom konst- och kulturprogram

- att upprätthålla kommunikation och dialog mellan nordiska och italienska nätverk

- att finna en breddad finansiering som täcker $10 \%$ av husets totala budget.

Orkester Norden tilldelas 1031000 DKK i 2015 års priser. Målet med verksamheten under året är:

att skapa en orkester genom att samla musikstuderande i åldrarna 15-25 år från de nordiska och baltiska länderna. Kursen ska vara i tre veckor. Målet är att genomföra 14 dagars repetitioner, master classes och workshops och avsluta med konsert i Musikens hus i Aalborg och en veckolång turné, preliminärt i Danmark, Norge och ev. Island.

Nordisk biblioteksvecka tilldelas 516000 DKK i 2015 års priser. Målet med verksamheten under året är: - att främja det generella läsandet samt främja den nordiska gemenskapen och samverkan mellan nordiska och baltiska bibliotek, skolor och Nordenföreningar. - att öka synligheten för projektet genom att utveckla interaktiviteten på nätet.

- att utveckla samarbetet med Nordiska rådets barn- och ungdomslitteraturpris.

Debutantseminariet på Nordens folkhögskola Biskops-Arnö tilldelas 225 000 DKK i 2015 års priser. Målet med verksamheten under året är:

- att samla debuterande författare från hela Norden för att stimulera utvecklingen av nya nordiska författarskap och att skapa nya nätverk mellan författare från hela Norden. 
4-2234 Samiskt samarbete

Organisationsbidrag
\begin{tabular}{|l|c|c|c|c|c|} 
Valuta & Budget 2016 & Budget 2015 & Budget 2014 & Disp./bud. 14 & Budget disp. af \\
\hline DKK & 3.758 .000 & 3.758 .000 & 3.702 .000 & $97 \%$ & Samerådet och \\
& & & & Samiska \\
konstnärsrådet
\end{tabular}

Formål Formålet med organisationsbidraget til Samerrådet og Samisk Kunstråd er at støtte det samiske kultursamarbejde samt at synliggøre og formidle samiske kunst og kultur både indenfor og udenfor det samiske samfund samt fremme en samlet samisk kulturpolitik i Norden og Nordvest Rusland.

I overensstemmelse med den af MR-K besluttede strategi er følgende mål fastlagt for 2016:

\begin{tabular}{|c|c|c|}
\hline \multicolumn{3}{|l|}{ atopfølgning } \\
\hline 2016 - Mål & 015 - Mål & 2014 - Opnåede resultater \\
\hline $\begin{array}{l}\text { Udvælgelse af stipendier og } \\
\text { projekter som støtter og udvikler } \\
\text { de lokale samiske kunstnere og } \\
\text { kulturaktører. } \\
\text { Formidling og synliggørelse af } \\
\text { samisk kunst og kultur både } \\
\text { inden for og uden for Norden. } \\
\text { Etablering af kontakt til } \\
\text { kunstnere fra andre oprindelige } \\
\text { folk samt til andre } \\
\text { kunstnergrupper uden for } \\
\text { Norden. } \\
\text { Fremme af } \\
\text { medlemsorganisationernes } \\
\text { økonomiske og kunstneriske } \\
\text { interesser i forhandlinger med } \\
\text { nationale myndigheder. }\end{array}$ & $\begin{array}{l}\text { Udvælgelse af stipendier og } \\
\text { projekter som støtter og udvikler } \\
\text { de lokale samiske kunstnere og } \\
\text { kulturaktører. } \\
\text { Formidling og synliggørelse af } \\
\text { samisk kunst og kultur både } \\
\text { inden for og uden for Norden. } \\
\text { Etablering af kontakt til } \\
\text { kunstnere fra andre oprindelige } \\
\text { folk samt til andre } \\
\text { kunstnergrupper uden for } \\
\text { Norden. } \\
\text { Fremme af } \\
\text { medlemsorganisationernes } \\
\text { økonomiske og kunstneriske } \\
\text { interesser i forhandlinger med } \\
\text { nationale myndigheder. }\end{array}$ & $\begin{array}{l}\text { Der blev udvalgt stipendier og } \\
\text { projekter, som har gennemført } \\
\text { aktiviteter som f.eks. } \\
\text { kunstudstillinger, } \\
\text { teaterudstillinger, } \\
\text { kulturfestivaller, musikvideoer og } \\
\text { dokumentarfilm. } \\
\text { Samerådet og Samisk } \\
\text { Kunstnerråd har formildet og } \\
\text { synliggjort samisk kunst og } \\
\text { kultur og har nået et bredt } \\
\text { geografisk område. } \\
\text { Der er afholdt et stort samisk } \\
\text { kulturpolitisk seminar om } \\
\text { hvordan den samiske kultur kan } \\
\text { fremmes i et } \\
\text { grænseoverskridende perspektiv. }\end{array}$ \\
\hline
\end{tabular}

Målene søges realiseret hovedsageligt via stipendier og projektstøtte til samiske kunstnere og kulturaktører. 


\section{Fiskeri og havbrug, Jordbrug, Levnedsmidler og Skovbrug}

\section{Generel indledning}

Formål og Formålet med arbejdet inden for MR-FJLS er at fremme en bæredygtig udvikling inden Fakta for de fire sektorer fiskeri og havbrug, jordbrug, levnedsmidler og skovbrug.

Arbejdet inden for MR-FJLS fokuserer på, hvordan de nordiske lande kan tilpasse sig til de globale udfordringer, og der hvor det er relevant, hvordan de nordiske lande gennem fælles bidrag kan påvirke de internationale tendenser i en for Norden positiv retning. Samarbejdet inden for MR-FJLS fastlægges i et rammeprogram, som gælder for perioder på tre år og som udmøntes gennem FJLS budgetposterne. I det gældende rammeprogram fokuseres på tre overordnede udfordringer, som alle præges af, at de er grænseoverskridende og derfor også er en del af den globale dagsorden, som Norden og MR-FJLS sektorerne må forholde sig til.

Strategiske målsætninger 2016
Ministerrådets resultater i 2014
Arbejdet inden for MR-FJLS er styret af et rammeprogram - Ramprogram for det nordiske samarbejde indenfor fiskeri, vandbrug, landbrug, levnedsmidler og skovbrug 2013-2016. Rammeprogrammet udstikker de overordnede rammer for hvilke udfordringer samarbejdet skal arbejde i forhold til.

Konkurrencedygtig produktion, bæredygtig naturressourceforvaltning samt opretholdelse og udvikling af de nordiske velfcerdssamfund.

Rammeprogrammet for de enkelte år i programperioden præciseres og komplementeres af formandskabsprogrammer. Disse udgør tilsammen handlingsprogrammet for samarbejdet.

For 2016 under finsk formandskab vil der således blive lagt vægt på, at samarbejdet inden for MR-FJLS bidrager med tiltag og løsninger i forhold til indsatserne "Natur", "Vand", og "Mennesker".

Under disse overskrifter vil bidragene fra MR-FJLS have hovedfokus på blå bioøkonomi, derudover genbrug af næringsstoffer, en nordisk konkurrence i "madhåndværk", natur og kulturturisme, landdistrikterne og digitalisering, og opfølgning på nordisk skovstrategi.

Ud over det finske formandskabsprogram for 2016, har MR-FJLS et særligt ansvar i forhold til det islandske formandskabsprogram for 2014 og det danske formandskabsprogram 2015 vedrørende bioøkonomi. Dette ansvar fortsættes i 2016 og indebærer dermed central opmærksomhed på bioøkonomispørgsmålet.

Det danske formandskab for 2015 har derudover fremmet flere sager, som også vil få strategisk betydning for indsatsen i 2016. Det gælder blandt andet i forhold til arbejdet med kortlægning af havbunden, fokus på One Health - antibiotikaresistens problematikken og opfølgning herpå og arbejdet med New Nordic Ultra og nordisk mad til at brande norden.

MR-FJLS vil også i 2016 have et internationalt fokus, hvilket vil indebære strategisk fokus på relationerne til og samarbejdet indenfor FAO, WHO, EU (EU's Østersøstrategi), OECD og Commonwealth.

I 2014 blev arbejdet i MR-FJLS styret af rammeprogrammet for det nordiske samarbejde indenfor fiskeri, vandbrug, landbrug, levnedsmidler og skovbrug 20132016, det overordnede islandske formandskabsprogram "Grokraft Livskraft" og 
sektorprogram for fiskeri og havbrug, landbrug, levnedsmidler og skovbrug 2014.

Resultaterne fra ministerrådets arbejde i 2014 disponeres overordnet set i MR-FJLS budget med udgangspunkt i de tre overordnede udfordringer, som er skiteseret i rammeprogrammet: Konkurrencedygtig produktion, Bceredygtig naturressourceforvaltning og Opretholdelse og udvikling af de nordiske velfcerdssamfund. Specifikt for resultaterne vedrørende de tre udfordringer henvises til resultaterne under de enkelte budgetposter under FJLS.

Arbejdet inden for MR-FJLS i 2014 står naturligvis ikke alene, men har sammenhæng til de foregå ende års indsatser. Arbejdet med bioøkonomi inden for MR-FJLS har i 2013 ledt til at bioøkonomi er blevet et centralt politisk tema i det nordiske samarbejde, og at der er igangsat en række forskellige initiativer på nordisk plan. I 2014 fremkom der resultater fra det arbejde der begyndte i 2013, bl.a. Arktisk Bioøkonomi og i EU's Østersøstrategi. Disse resultater har været udgangspunkt for videreudvikling af bioøkonomi i nordisk regi.

NMR fortsætter med at lede prioritering af bioøkonomi i EU’s Østersøstrategi (EUSBSR). Hovedfokus har været på igangsættelse af aktioner og at facilitere samarbejdsprocesser og netværksdannelse. Hovedinstrumentet til at opnå resultater er indsatsen "Realizing the Bioeconomy in the Baltic Sea Region.” med tilknyttede workshops, der i 2014 blev udført i Tallinn, Berlin og Warszawa. Dette resultat bidrager samtidig til ministerrådets indsats vedrørende partnerskab og grænseregionalt samarbejde.

MR-FJLS tog ansvar for udvikling og gennemførelse af et side event på FAO/WHO ICN2 (International Conference of Nutrition 2) i Rom, den nordiske indflydelse på side eventet havde stor gennemslagskraft._Der blev også til eventet udarbejdet et microsite "Nutrition - the Nordic Way", der både til selve konferencen, men også efterfølgende skal anvendes til at profilere den samlede indsats på det ernæringsmæssige område.

MR-FJLS har i 2014 derudover fortsat leveret resultater i forhold til flere tværsektorielle politiske prioriteringer. Dette gælder ikke mindst i forhold til bæredygtig udvikling og ligestilling, hvor MR-FJLS aktivt har medvirket til at skabe politisk opmærksomhed og debat.

MR-FJLS er også aktiv bidragsyder til resultater inden for Statsministrenes initiativ om Grøn Vækst. FJLS har delansvar i forhold til flere af initiativerne, men indsatsen omkring madspild, skal i sær fremhæves, hvor der er initieret en større tværsektoriel indsats til adressering af madspildsproblemet, denne indsats har været med til at facilitere en stigende tværsektoriel opmærksomhed og fælles tilgang til problemet. 


\begin{tabular}{|c|c|c|c|c|c|}
\hline & \multirow{2}{*}{$\begin{array}{r}\text { Budget } \\
2016\end{array}$} & \multirow{2}{*}{$\begin{array}{r}\text { Budget } \\
2015\end{array}$} & \multicolumn{2}{|c|}{ Difference } \\
\hline & & & & $+/-$ & $\%$ \\
\hline \multicolumn{2}{|c|}{$\begin{array}{l}\text { Sum MR-FJLS (TDKK) } \\
\text { (TDK) }\end{array}$} & 39.769 & 39.769 & $\overline{0}$ & $0,0 \%$ \\
\hline & Projektmidler & 907 & 907 & 0 & $0,0 \%$ \\
\hline \multirow[t]{2}{*}{$5-6420$} & Ny nordisk mad & 907 & 907 & 0 & $0,0 \%$ \\
\hline & Fiskeri & 6.198 & 6.198 & 0 & $0,0 \%$ \\
\hline \multirow[t]{3}{*}{$\overline{5-6610}$} & Projektmedel - Fiskeri & 6.198 & 6.198 & 0 & $0,0 \%$ \\
\hline & Jord- och skovbrug & 27.071 & 27.071 & 0 & $0,0 \%$ \\
\hline & Projektmidler - jordbrug & 1.188 & 1.188 & 0 & $0,0 \%$ \\
\hline $5-6510$ & Projektmidler Jordbrug & 369 & 369 & 0 & $0,0 \%$ \\
\hline \multirow{2}{*}{$5-6520$} & Nordiskt kontaktorgan för jordbruksforskning (NKJ) & 819 & 819 & 0 & $0,0 \%$ \\
\hline & Institutioner - jordbrug & 20.016 & 20.016 & 0 & $0,0 \%$ \\
\hline \multirow[t]{2}{*}{$5-6585$} & Nordisk Genressource Center (NordGen) & 20.016 & 20.016 & 0 & $0,0 \%$ \\
\hline & Projektmidler - skovbrug & 5.867 & 5.867 & 0 & $0,0 \%$ \\
\hline $5-6310$ & Projektmidler Skovbrug & 306 & 306 & 0 & $0,0 \%$ \\
\hline \multirow[t]{2}{*}{$5-6581$} & Samnordisk skogsforskning (SNS) & 5.561 & 5.561 & 0 & $0,0 \%$ \\
\hline & Levnedsmidler & 5.593 & 5.593 & 0 & $0,0 \%$ \\
\hline $5-6810$ & Projektmedel - Levnedsmidler & 5.046 & 5.046 & 0 & $0,0 \%$ \\
\hline $5-6830$ & Nordisk handlingsplan for bedre helse og livskvalitet & 547 & 547 & 0 & $0,0 \%$ \\
\hline \multicolumn{2}{|c|}{ Opdelt på kategorier } & 39.769 & 39.769 & $100 \%$ & $100 \%$ \\
\hline & Projektmidler & 12.466 & 12.466 & $31,3 \%$ & $31,3 \%$ \\
\hline & Programlignende aktiviteter & 7.287 & 7.287 & $18,3 \%$ & $18,3 \%$ \\
\hline & Institutioner & 20.016 & 20.016 & $50,3 \%$ & $50,3 \%$ \\
\hline
\end{tabular}

\section{$\underline{\text { 5-6420 Ny nordisk mad }}$}

Programlignende aktiviteter
\begin{tabular}{|l|c|c|c|c|c|} 
Valuta & Budget 2016 & Budget 2015 & Budget 2014 & Disp./bud. 14 & Budget disp. af \\
\hline DKK & 907.000 & 907.000 & 1.716 .000 & $100 \%$ & $\begin{array}{c}\text { EK-FJLS } \\
\text { (Eksekutiv) }\end{array}$
\end{tabular}

Formål Arbejdet med Ny Nordisk Mad er forankret inden for MR-FJLS, men har et tværsektoriel sigte. Efter to gennemførte programperioder (2007-2009 og 2010-2014) går arbejdet med Ny Nordisk Mad ind i en ny fase. Denne baseres på den forudgående indsats, som været medvirkende til at igangsætte en bemærkelsesværdig forandring og udvikling.

Den nye fase for Nordisk Ministerråds indsats om Ny Nordisk Mad, som indledes i 2015 benytter sig af, at Ny Nordisk Mad er blevet kendt og i vidt omfang også integreret i tænkning og økonomi.

Indsatsen fra Nordisk Ministerråd vil derfor have fokus på at styrke netværksdannelsen på strategisk niveau blandt centrale nordiske institutioner samt at gennemføre en styrket brandingmæssig indsats.

\begin{tabular}{|l|l|l|}
\hline Mål og resultatopfølgning & 2015 - Mål & 2014 - Opnåede resultater \\
\hline 2016 - Mål & Fra 2015 og frem styres arbejdet & Året 2014 var det sidste år i \\
\hline Styregruppen for Ny Nordisk
\end{tabular}




\begin{tabular}{|c|c|c|}
\hline $\begin{array}{l}\text { Mad skal først og fremmest } \\
\text { fokusere på aktiviteter } \\
\text { vedrørende branding og styrket } \\
\text { netværksdannelse mellem } \\
\text { myndigheder og nationale } \\
\text { madinstitutioner og } \\
\text { organisationer. Det kan blandt } \\
\text { andet handle om arbejdet } \\
\text { vedrørende Nordic Food } \\
\text { Diplomacy. }\end{array}$ & $\begin{array}{l}\text { med Ny Nordisk Mad gennem en } \\
\text { styregruppe med udviklings- og } \\
\text { initieringsansvar og EK-FJLS } \\
\text { (Eksekutiv) med budgetansvar } \\
\text { (for så vidt angår midler allokeret } \\
\text { fra NMR/MR-FJLS). } \\
\text { Styregruppen opretholdes (og } \\
\text { tilpasses) som en arbejdsgruppe } \\
\text { under EK-FJLS (Eksekutiv). } \\
\text { Gruppen sammensættes med op } \\
\text { til } 8 \text { medlemmer, som kommer } \\
\text { fra landene samt Færøerne, } \\
\text { Grønland og Åland. } \\
\text { Arbejdsgruppens opgave er først } \\
\text { og fremmest, at opretholde og } \\
\text { udvikle konceptet NNM, foruden } \\
\text { at stimulere, behandle og } \\
\text { udarbejde konkrete forslag til } \\
\text { aktiviteter, projekter etc. Med } \\
\text { henblik på anvendelse af de } \\
\text { afsatte midler. }\end{array}$ & $\begin{array}{l}\text { programperioden } 2010-2014 \\
\text { hvilket medførte at stor del af } \\
\text { aktiviteterne bestod i at runde af } \\
\text { og afklare hvordan visse } \\
\text { aktiviteter inden for programmet } \\
\text { kunne fortsættes i samarbejde } \\
\text { mellem landene. Det handler især } \\
\text { om branding af nordiske } \\
\text { fødevarer og videreførelse af det } \\
\text { omfattende netværksaktivet som } \\
\text { er blevet opbygget inden for Ny } \\
\text { Nordisk Mad. } \\
\text { En slutrapport forventes til } \\
\text { midten af maj } 2015 \text {. }\end{array}$ \\
\hline
\end{tabular}

Fiskeri

$\underline{\text { 5-6610 Projektmidler - Fiskeri }}$

Projektmidler
\begin{tabular}{|l|c|c|c|c|c|} 
Valuta & Budget 2016 & Budget 2015 & Budget 2014 & Disp./bud. 14 & Budget disp. af \\
\hline DKK & 6.198 .000 & 6.198 .000 & 6.106 .000 & $100 \%$ & $\begin{array}{c}\text { EK-FJLS (Fiskeri } \\
\text { og Havbrug) }\end{array}$
\end{tabular}

Formål Formålet er at understøtte aktiviteter i forhold til samarbejds- og statsministrenes prioriteringer, FJLS rammeprogram 2013-2016, formandskabsprioriteringer, og fiskerisektorstrategien. Sektorindsatserne er opdelt efter hovedprioriteringerne i FJLS rammeprogram, som er konkurrencedygtig produktion, bæredygtig ressourceforvaltning og opretholdelse og udvikling af de nordiske velfærdssamfund. Den samlede indsats koncentrerer sig om bæredygtig forvaltning og udvikling af fiskeri og havbrug i Norden. Konkret gøres dette i nordisk arbejdsgruppe for fiskeri og havbrug, midlerne bruges endvidere til at støtte aktiviteter i regi af embedsmandskomiteen og gennemførelse af formandskabsprogrammet.

\begin{tabular}{|c|c|c|}
\hline \multicolumn{3}{|c|}{ encedygtig produktion } \\
\hline 2016 - Mål & 2015 - Mål & 014 - Opnåede resultater \\
\hline $\begin{array}{l}\text { De konkrete mål er sat i relation } \\
\text { til Finlands formandskabs projekt } \\
\text { om blå bioøkonomi, samt det } \\
\text { islandske formandskabsprogram } \\
\text { NordBio og det danske } \\
\text { formandskabs flagskibsprojekt, } \\
\text { under Færøsk ledelse, Vækst i } \\
\text { Blå Bioøkonomi. } \\
\text { Fokusområderne for } 2016 \\
\text { inkluderer: }\end{array}$ & $\begin{array}{l}\text { danske formandskabsprogram, } \\
\text { Vækst, Værdier, Velfærd og det } \\
\text { Blå Arktis, i FJLS’ } \\
\text { Rammeprogram 2013-2016 og i } \\
\text { fiskerisektorprogrammet 2015, } \\
\text { under færøsk formandskab. } \\
\text { Et af flagskibsprojekterne i dansk } \\
\text { formandskabsprogram er Vcekst i } \\
\text { blå bioøkonomi i Nordøst }\end{array}$ & $\begin{array}{l}\text { Det overordnede islandske } \\
\text { formandskabsprogram, NordBio, } \\
\text { havde fokus på havets ressourcer, } \\
\text { især i temaprojektet Innovation i } \\
\text { nordisk bioøkonomi. Projektet } \\
\text { støttede } 60 \text { mindre virksomheder } \\
\text { i de Vestnordiske lande i } \\
\text { udvikling og innovation af varer } \\
\text { og tjenester. Nogle af } \\
\text { produkterne blev præsenterede på }\end{array}$ \\
\hline
\end{tabular}




\begin{tabular}{|c|c|c|}
\hline $\begin{array}{l}\text { Større strategisk betydning af blå } \\
\text { bioøkonomi i Norden. } \\
\text { Blå bioøkonomi road map for } \\
\text { Norden. } \\
\text { Mere forsknings- og } \\
\text { innovationssamarbejde på blå } \\
\text { bioøkonomi områder der giver } \\
\text { nordisk mervcrdi. } \\
\text { Innovation i nordisk bioøkonomi. } \\
\text { En nordisk bioøkonomi } \\
\text { konference i } 2016 . \\
\text { Arktisk og baltisk bioøkonomi. }\end{array}$ & $\begin{array}{l}\text { Atlanten og i Arktis. Projektet } \\
\text { indeholder flere delprojekter som } \\
\text { hver især adresserer } \\
\text { erhverfsrelevante bioøkonomiske } \\
\text { problemstillinger. Fokus bliver på } \\
\text { Alt i land og makroalger. } \\
\text { Konferencen Vakst i blå } \\
\text { bioøkonomi i Nordøst Atlanten og } \\
\text { i Arktis finder sted på Færøerne i } \\
\text { primo juni. Konference om } \\
\text { recirkulationsanlæg i } \\
\text { akvakulturen afholdes i Molde, } \\
\text { Norge i oktober. Endvidere } \\
\text { arrangeres aktiviteter, hvor tang } \\
\text { præsenteres som mad. Arbejde } \\
\text { med rammebetingelser og } \\
\text { governance. }\end{array}$ & $\begin{array}{l}\text { Konference om nordisk og } \\
\text { arktisk bioøkonomi, Nordtic, der } \\
\text { blev afholdt back-to-back med } \\
\text { MR-FJLS. } \\
\text { Den afsluttende konference for } \\
\text { Nordisk Marine Innovations } \\
\text { Program, blev afhold i } 2014 \text { og } \\
\text { ny programfase blev initieret. } \\
\text { MIP er samarbejde mellem } \\
\text { Nordisk Innovation, landenes } \\
\text { innovations og forskningsråd og } \\
\text { fiskerisamarbejdet. }\end{array}$ \\
\hline
\end{tabular}

\begin{tabular}{|c|c|c|}
\hline \multicolumn{3}{|c|}{ Mål og resultatopfølgning - Bæredygtig naturressourceforvaltning } \\
\hline 2016 - Mål & 2015 - Mål & 2014 - Opnåede resultater \\
\hline $\begin{array}{l}\text { De konkrete mål er sat i relation } \\
\text { til Finlands formandskabs projekt } \\
\text { om blå bioøkonomi, samt det } \\
\text { islandske formandskabsprogram } \\
\text { NordBio og det danske } \\
\text { formandskabs flagskibsprojekt, } \\
\text { under Færøsk ledelse, Vækst i } \\
\text { Blå Bioøkonomi. } \\
\text { Fokusområderne for } 2016 \\
\text { inkluderer: } \\
\text { Større strategisk betydning af blå } \\
\text { bioøkonomi i Norden. } \\
\text { Blå bioøkonomi road map for } \\
\text { Norden. } \\
\text { Mere forsknings- og } \\
\text { innovationssamarbejde på blå } \\
\text { bioøkonomi områder der giver } \\
\text { nordisk mervcrdi. } \\
\text { Innovation i nordisk bioøkonomi. } \\
\text { En nordisk bioøkonomi } \\
\text { konference i 2016. } \\
\text { Arktisk og baltisk bioøkonomi. }\end{array}$ & $\begin{array}{l}\text { Mål for } 2015 \text { konkretiseres i det } \\
\text { danske formandskabsprogram, } \\
\text { Vækst, Værdier, Velfærd og det } \\
\text { Blå Arktis, i FJLS' } \\
\text { Rammeprogram 2013-2016 og i } \\
\text { fiskerisektorprogrammet 2015, } \\
\text { under færøsk formandskab. } \\
\text { Flagskibsprojektet Vakst i blå } \\
\text { bioøkonomi i Nordøst Atlanten og } \\
\text { i Arktis bidrager til udvikling af } \\
\text { bæredygtig } \\
\text { naturressourceforvaltning. Fokus } \\
\text { bliver på samarbejde med } \\
\text { internationale organer om } \\
\text { profilering og promovering af det } \\
\text { nordiske fiskerisamarbejde, bl.a. i } \\
\text { Bruxelles i marts og i forbindelse } \\
\text { med FN’s Food and Agricultural } \\
\text { Organization Code of Conduct } \\
\text { for Responsible Fisheries } \\
\text { Jubilæum i oktober. } \\
\text { Et andet af flagskibsprojekterne i } \\
\text { dansk formandskabsprogram er } \\
\text { Havbundskortlcgning i Arktis og } \\
\text { Nordatlanten der vil udvikle en } \\
\text { fælles nordisk protokol til } \\
\text { kortlægning og monitering af } \\
\text { havbundens biodiversitet og } \\
\text { sårbarhed og dermed danne et } \\
\text { bedre grundlag for } \\
\text { Økosystembaseret Forvaltning. }\end{array}$ & $\begin{array}{l}\text { Det overordnede islandske } \\
\text { formandskabsprogram, NordBio, } \\
\text { havde fokus på havets ressourcer, } \\
\text { især i temaprojektet Innovation i } \\
\text { nordisk bioøkonomi. } \\
\text { Der blev udgivet en rapport om } \\
\text { Marine Spatial Planlægning, især } \\
\text { med hensyn til EU’s Natura } 2000 \\
\text { beskyttede naturområder. } \\
\text { Fiskerisamarbejdet støttede } \\
\text { aktiviteter der øgede } \\
\text { videnskabsgrundlaget for de } \\
\text { pelagiske bestande i nordiske } \\
\text { have. Der blev igangsat arbejde } \\
\text { med policy rekommandationer } \\
\text { vedrørende klimapåvirkninger på } \\
\text { primærerhvervene. }\end{array}$ \\
\hline
\end{tabular}

Mål og resultatopfølgning - Opretholdelse og udvikling af de nordiske velfærdssamfund

\begin{tabular}{|l|l|l|}
\hline 2016 - Mål & 2015 - Mål & 2014 - Opnåede resultater \\
\hline De konkrete mål er sat i relation & Mål for 2015 konkretiseres i det & I 2014 opnåede \\
\hline
\end{tabular}




\begin{tabular}{|c|c|c|}
\hline $\begin{array}{l}\text { til Finlands formandskabs projekt } \\
\text { om blå bioøkonomi, samt det } \\
\text { islandske formandskabsprogram } \\
\text { NordBio og det danske } \\
\text { formandskabs flagskibsprojekt, } \\
\text { under Færøsk ledelse, Vækst i } \\
\text { Blå Bioøkonomi. } \\
\text { Fokusområderne for } 2016 \\
\text { inkluderer: } \\
\text { Større strategisk betydning af blå } \\
\text { bioøkonomi i Norden. } \\
\text { Blå bioøkonomi road map for } \\
\text { Norden. } \\
\text { Mere forsknings- og } \\
\text { innovationssamarbejde på blå } \\
\text { bioøkonomi områder der giver } \\
\text { nordisk merværdi. } \\
\text { Innovation i nordisk bioøkonomi. } \\
\text { En nordisk bioøkonomi } \\
\text { konference i } 2016 . \\
\text { Arktisk og baltisk bioøkonomi. }\end{array}$ & $\begin{array}{l}\text { danske formandskabsprogram, } \\
\text { Vækst, Værdier, Velfærd og det } \\
\text { Blå Arktis, i FJLS' } \\
\text { Rammeprogram 2013-2016 og i } \\
\text { fiskerisektorprogrammet 2015, } \\
\text { under færøsk formandskab. } \\
\text { Der arrangeres et } \\
\text { samarbejdsforum mellem } \\
\text { kystfiskerorganisationerne og } \\
\text { turismeindustrien. }\end{array}$ & $\begin{array}{l}\text { fiskerisamarbejdet sine } \\
\text { målsætninger vedrørende } \\
\text { kystsamfundsudvikling, med at } \\
\text { udarbejde og publicere en rapport } \\
\text { om Kystsamfund i Nordøst } \\
\text { Atlanten og holde en workshop } \\
\text { om samme emne. En } \\
\text { slutkonference om Arktis } \\
\text { Bioøkonomi blev også holdt med } \\
\text { fokus på Vestnorden og det høje } \\
\text { nord. }\end{array}$ \\
\hline
\end{tabular}

\section{Jordbrug}

5-6510-1 Projektmidler - Jordbrug

Projektmidler
\begin{tabular}{|l|c|c|c|c|c|} 
Valuta & Budget 2016 & Budget 2015 & Budget 2014 & Disp./bud. 14 & Budget disp. af \\
\hline DKK & 369.000 & 369.000 & 364.000 & $78 \%$ & EK-FJLS \\
(Jordbrug)
\end{tabular}

Formål Formålet er at understøtte aktiviteter i forhold til konkurrencedygtig produktion, bæredygtig ressourceforvaltning og at opretholde og videreudvikle de nordiske velfærdssamfund. Arbejdet inden for EK-FJLS (Jordbrug) sker i tæt relation til Nordisk kontaktorgan for jordbrugsforskning (NKJ), NordGen, Ny Nordisk Mad indsatsen og arbejdet omkring bioøkonomi. Komiteen råder over en mindre budgetpost, som anvendes til at understøtte mere policy rettede aktiviteter i regi af embedsmandskomiteen og gennemførelse af formandskabsprogrammet. Budgetposten understøtter det eksisterende samarbejde på nordiske jordbrugspolitiske område karakteristeret ved landenes engagement i netværk inden for området.

\begin{tabular}{|c|c|c|}
\hline \multicolumn{3}{|c|}{ Mål og resultatopfølgning- Konkurrencedygtig produktion } \\
\hline 2016 - Mål & 2015 - Mål & 2014 - Opnåede resultater \\
\hline $\begin{array}{l}\text { Fokusområderne for } 2016 \text { vil } \\
\text { inkludere bevaring af } \\
\text { næringsstoffer, en nordisk } \\
\text { konkurrence i madhåndværk og } \\
\text { natur- og kulturturisme. }\end{array}$ & $\begin{array}{l}\text { Vcekst, velfcerd og vœrdier } \\
\text { Øge kendskabet og interessen } \\
\text { for nordisk madkultur og } \\
\text { fødevarer gennem etablering af } \\
\text { en Nordisk Food Festival. } \\
\text { Desuden mere fokus på } \\
\text { udbredelse af fødevarer fra det } \\
\text { højeste nord som Island, }\end{array}$ & $\begin{array}{l}\text { Under det islandske formandskab } \\
\text { blev der set fokus på plante- } \\
\text { forædlingens rolle for bio- } \\
\text { økonomien og udviklingen af } \\
\text { økologisk produktion i Arktis. Det } \\
\text { første tema fik bla. fremgang ved et } \\
\text { vel lykket seminar, hvor deltagere i } \\
\text { det allerede etablerede partnerskab } \\
\text { lagde grunden til en videreførelse af }\end{array}$ \\
\hline
\end{tabular}




\begin{tabular}{|l|l|l|}
\hline & $\begin{array}{l}\text { Grønland og Færøerne gennem } \\
\text { madsymposiet New Nordic } \\
\text { Ultra }\end{array}$ & $\begin{array}{l}\text { arbejdet 2015 og fremad. På MR- } \\
\text { FJLS blev landene enige om at } \\
\text { fortsætte financieringen af } \\
\text { partnerskabet. } \\
\text { Det andet tema blev til et nordisk } \\
\text { projekt der afleverede slutrapport i } \\
\text { foråret 2015. Rapporten belyser de } \\
\text { fælles udfordringer for økologisk } \\
\text { produktion i det høje nord. Disse } \\
\text { indebærer vanskelligheder med } \\
\text { dyrkning af kvælstoffikserene } \\
\text { planter, mangel af halm til strøelse } \\
\text { for husdyr og tvivlsom dyrevelfærd } \\
\text { hos udegånde dyr. }\end{array}$ \\
\hline
\end{tabular}

\begin{tabular}{|c|c|c|}
\hline \multicolumn{3}{|c|}{ Mål og resultatopfølgning - Bæredygtig naturressourceforvaltning } \\
\hline 2016 - Mål & 2015 - Mål & 2014 - Opnåede resultater \\
\hline $\begin{array}{l}\text { De konkrete mål for } 2016 \text { vil } \\
\text { være bevaring af næringsstoffer, } \\
\text { en nordisk konkurrence i } \\
\text { madhåndværk og natur- og } \\
\text { kulturturisme. }\end{array}$ & $\begin{array}{l}\text { Jordbrugssamarbejdets indsats } \\
\text { vedrørende bæredygtig } \\
\text { naturressourceforvaltning er i høj } \\
\text { grad koblet til indsatsen omkring } \\
\text { genetiske ressourcer gennem } \\
\text { NordGen }\end{array}$ & $\begin{array}{l}\text { MR-FJLS igangsatte i } 2011 \text { et } \\
\text { pilotprojekt om et offentligt privat } \\
\text { partnerskab om plante-forædling i } \\
\text { Norden. Målet med partnerskabet } \\
\text { er, at styrke den nordiske } \\
\text { planteforædling med henblik på, at } \\
\text { styrke de nordiske landes } \\
\text { landbrugserhvervs tilpasning til og } \\
\text { udvikling i et forandret klima samt } \\
\text { at styrke den nordiske } \\
\text { planteforædling generelt. } \\
\text { I } 2014 \text { blev partnerskabet fornyet } \\
\text { og forlænget med national } \\
\text { finansiering. }\end{array}$ \\
\hline
\end{tabular}

\section{$\underline{\text { 5-6520 Kontaktorgan for jordbrugsforskning }}$}

Programlignende aktiviteter

\begin{tabular}{|l|c|c|c|c|c|} 
Valuta & Budget 2016 & Budget 2015 & Budget 2014 & Disp./bud. 14 & Budget disp. af \\
\hline DKK & 819.000 & 819.000 & 807.000 & $100 \%$ & NKJ
\end{tabular}

Formål Nordisk komite for Jordbrugs- og madforskning (NKJ) har som overordnet mål, at bidrage til en viden baseret jordbrugs- og madsektor i de nordiske lande. Dette sikres gennem at fremme og støtte nordisk forskningssamarbejde i jordbrugs- og madsektorerne. NKJs arbejde skal tilføre et merværdi til forskningen på national og europæisk niveau. NKJ skal bidrage til national, nordisk og europæisk politikudformning inden for sit ansvarsområde og har en rådgivende funktion overfor Nordisk Ministerråd i forskningspolitiske spørgsmål som vedrører jordbrugs- og madforskning.

Forvaltnings- NKJ's sekretariat varetages af NordForsk men forventes at blive flyttet til Sveriges organ lantbruksuniversitet SLU og nærmere Samnordisk Skogsforskning fra 1. januar 2016. Bidraget til NKJ fra Nordisk Ministerråd anvendes til strategiske policy relaterede aktiviteter, mens sekretariatsfunktionen finansieres gennem nationale medlemsafgifter. 


\begin{tabular}{|c|c|c|}
\hline \multicolumn{3}{|l|}{ Mål og resultatopfølgning } \\
\hline 2016 - Mål & 2015 - Mål & 2014 - Opnåede resultater \\
\hline $\begin{array}{l}\text { Under } 2016 \text { fortsätter arbetet med } \\
\text { att genomföra aktiviteter enligt } \\
\text { den nya strategin för åren 2015- } \\
2018 . \\
\text { Förutom prioriteringarna på } \\
\text { bioekonomi, klimatförändringar } \\
\text { och one health - } \\
\text { antibiotikaresistens så avser NKJ } \\
\text { även att genom utlysningar till } \\
\text { stöd för nätverksaktiviteter, } \\
\text { kunna knyta till sig nordiska } \\
\text { forskargrupper inom områden } \\
\text { under lantbruks- och } \\
\text { matforskning. } \\
\text { Stöd till renforskning har skett } \\
\text { som bidrag till en forskarskola } \\
\text { och stöd till seminarier, men nya } \\
\text { former av finansiering för } \\
\text { utveckling av nordiska } \\
\text { renforskningen skall prövas. } \\
\text { Synergier i samarbetet med } \\
\text { Samnordisk skovforskning (SNS) } \\
\text { och andra Nordiska arbetsgrupper } \\
\text { skall vidare utforskas. }\end{array}$ & $\begin{array}{l}\text { I } 2015 \text { indledes en ny } \\
\text { strategiperiode, som gælder for } \\
\text { årene 2015-2018. Strategien } \\
\text { forventes godkendt endeligt af } \\
\text { NKJ og EK-FJLS (Jordbrug) } \\
\text { ultimo 2014. } \\
\text { Med den nye strategi vil arbejdet } \\
\text { med at bidrage til en } \\
\text { kundskabsbaseret udvikling for } \\
\text { jordbrugs og madsektorerne i de } \\
\text { nordiske lande, hermed vil der } \\
\text { være fokus på forskning og } \\
\text { innovation. } \\
\text { Den nye strategi vil have } \\
\text { bioøkonomi, klimaforandringer } \\
\text { og One Health- } \\
\text { antibiotikaresistens } \\
\text { problematikken som de } \\
\text { overordnede substantielle } \\
\text { prioriteter. }\end{array}$ & $\begin{array}{l}\text { En ny strategi for årene 2015- } \\
2018 \text { blev udformet og godkendt } \\
\text { af NKJ bestyrelse og EK-FJLS } \\
\text { (Jordbrug). } \\
\text { Nordic Bioeconomy Initiative, } \\
\text { som NKJ har hovedaktie i har } \\
\text { dannet grundlaget for } \\
\text { NordForsk's forslag til et nordisk } \\
\text { forskningsprogram på grøn } \\
\text { tilvækst, for den andel som } \\
\text { omfatter bioøkonomi. } \\
\text { NKJ havde to ansøgningsrunder } \\
\text { for støtte i 2014. Den ene for } \\
\text { støtte til Work-shops/seminarer } \\
\text { /konferancer med det formål at } \\
\text { promotere nordisk forskning og } \\
\text { innovation inden landbruget og } \\
\text { livsmiddelsektoren og den anden } \\
\text { til støtte til tværsektorielle } \\
\text { nordiske netværk i biobaseret } \\
\text { økonomi med fokus på de } \\
\text { nordiske udfordringer for } \\
\text { biomasse udnyttelse og arealbrug } \\
\text { for biomasseproduktion i } \\
\text { samarbejde med Samnordisk } \\
\text { skovforskning (SNS)- }\end{array}$ \\
\hline
\end{tabular}

$\underline{\text { 5-6585 Nordisk Genressource Center (NordGen) }}$

Institution

\begin{tabular}{|l|c|c|c|c|c|} 
Valuta & Budget 2016 & Budget 2015 & Budget 2014 & NMR fin. 14 & Budget disp. af \\
\hline SEK & 24.116 .000 & 24.116 .000 & 23.920 .000 & $75 \%$ & NordGen \\
\hline Modsv. DKK & 20.016 .000 & 20.016 .000 & 20.810 .000 & &
\end{tabular}

Formål NordGens övergripande mål är att säkerställa bevarande och hållbart nyttjande av genetiska resurser (GR) i de nordiska länderna. NordGen bidrar till framtida livsmedelsförsörjningen, samtidigt som miljön och den biologiska mångfalden säkerställs genom bevarande och hållbart nyttjande av genetiska resurser av relevans och nytta för jord-och skogsbruk i de nordiska länderna.

NordGen stöder länderna och NMR med sakkunskap i såväl sak- som policyfrågor avseende Genetiske resurser.

Kontraktperiode Den nuværende kontrakt gælder for perioden 2015-2017. Kontrakten er opfyldt hvad an og status 2014. 


\begin{tabular}{|c|c|c|}
\hline \multicolumn{3}{|l|}{ Mål og resultatopfølgning } \\
\hline 2016 - Mål & 2015 - Mål & 2014 - Opnåede resultater \\
\hline $\begin{array}{l}\text { NordGen kommer } 2016 \text { att aktivt } \\
\text { bidra till det nordiska bioekonomi } \\
\text { initiativ och öka förståelsen och } \\
\text { tillgång till genetiska resurser. } \\
\text { Den pågående } \\
\text { klimatförändringen kommer att } \\
\text { öka behovet av genetisk variation } \\
\text { i växtförädling, djuravl och } \\
\text { förnyelse av skogar. } \\
\text { Ökad användning av genetisk } \\
\text { variation kan minska jordbrukets } \\
\text { miljöpåverkan och för att hjälpa } \\
\text { jordbruket att anpassa sig till } \\
\text { framtida klimatförändringar. } \\
\text { Växtsektorn fortsä̈ter fokus på } \\
\text { kvalitet säkra samlingarna och } \\
\text { säkra backup för allt material. Ett } \\
\text { särskilt fokus kommer att ligga } \\
\text { på den stora variationen inom } \\
\text { proteingrödor. } \\
\text { Projektet ’Private Public } \\
\text { Partnership’ som behandlar pre- } \\
\text { breeding fortsätter i perioden } \\
\text { 2015-2017. Syftet med projektet } \\
\text { är att säkra utvecklingen av } \\
\text { plantmaterial, som är tillpassat } \\
\text { den nordiska regionen. I projektet } \\
\text { deltar förädlingsverksamheter, } \\
\text { universitet och myndigheter från } \\
\text { alla de fem nordiska länderna. } \\
\text { Husdjur sektorn kommer att } \\
\text { fortsättta sitt arbete med att stärka } \\
\text { service roll för nationella } \\
\text { aktiviteter och förstärka sitt fokus } \\
\text { på de aktiva raser i länderna. } \\
\text { Skogssektorn fortsätter att } \\
\text { uppföljnings arbetet efter klimat } \\
\text { enkäten i nära samarbete med } \\
\text { andra relevanta nationella och } \\
\text { nordiska myndigheter med } \\
\text { särskiltt fokus på trädförädling } \\
\text { och utsädesproduktion. }\end{array}$ & $\begin{array}{l}\text { Utarbeta 20-årsplan för } \\
\text { kvalitetssäkring och regenering } \\
\text { av genbanks frösamling. } \\
\text { Växter - Inventering, grobarhets- } \\
\text { tester och regenerering } \\
\text { prioriterat. Focus på att } \\
\text { effektivisera och beskydda } \\
\text { uppförökningsfält mot externa } \\
\text { hot. In vitro - potatissamlingen, } \\
\text { uppstart av extern back up. } \\
\text { Klimafrågor och holdbar } \\
\text { utveckling fokus for husdjur och } \\
\text { skog. } \\
\text { Anpassa personalpolicy, } \\
\text { arbetsmiljöpolicy, } \\
\text { arbetsrutiner/strategier efter nya } \\
\text { stadgar och det nya arbetssättet } \\
\text { inom ministerrådet. }\end{array}$ & $\begin{array}{l}\text { NordGen var den första nordiska } \\
\text { institution som avslutat den nya } \\
\text { styrings modellen som fölge av } \\
\text { Nyt Norden och ändringarna } \\
\text { trädde i kraft } 1 \text { januari } 2015 . \\
\text { NordGen växter havde fokus på } \\
\text { forberedelse av } 20 \text { år plan for } \\
\text { kvalitetssikring og regenerering } \\
\text { av frösamlingen. Distributionen } \\
\text { av frö ökade under } 2014 \text { och } \\
\text { 9090 fröprover distribuerades } \\
\text { fördelat på } 891 \text { beställare jämfört } \\
\text { med } 6132 \text { fröprov fördelat på } 613 \\
\text { beställare i föregående år. } \\
\text { NordGen Husdjur har initierat ett } \\
\text { projekt för att definiera och } \\
\text { operationalisera begreppet hållbar } \\
\text { avel. NordGen har etablerat } \\
\text { nätverk och är sekretariat för } \\
\text { NordMilk med forsknings- } \\
\text { institutioner från alla nordiska } \\
\text { länder om karakterisering av } \\
\text { mjölk från nationell raser. } \\
\text { NordGen Husdjur var den } \\
\text { primära arrangör av den } \\
\text { avslutande konferensen Genetic } \\
\text { Resources for Food and } \\
\text { Agriculture in a Changing } \\
\text { Climate } \\
\text { Tema } 2014 \text { NordGen skog var } \\
\text { skogbehangdling i relation till } \\
\text { klimatförändringar, effektivitet i } \\
\text { behandling, nordic tillgång till } \\
\text { förädlade frö, nordiskt samarbete } \\
\text { om bruks områden för frökilder } \\
\text { av gran och tall. } \\
\text { NordGen hade omfattande } \\
\text { förändringar i personal under } \\
2014 \text { på grund av } 8 \text { årsregeln och } \\
\text { stort arbete med att förbereda } \\
\text { kommande förändringar för } 2015 . \\
\text { Lönehantering har tidigarer varit } \\
\text { utlokaliserat till Statens } \\
\text { Servicecenter men NordGen har } \\
\text { 2014 övertagit detta i egen regi } \\
\text { och installerat ett välfungerande } \\
\text { lönesystem. }\end{array}$ \\
\hline
\end{tabular}

Realiseringen af NordGens mål sker i stor udstrækning gennem NordGens arbejdsgrupper og netværk. Arbejdsgrupperne og netværkene er vigtigt komponenter i NordGens arbejde. Den nordiske nytte af disse er stor, da de både er omkostningseffektive, og har stor nytte for alle de nordiske lande. NordGen er organiseret med tre afdelinger: NordGen Planter, NordGen Skov og NordGen Husdyr. 


\section{Levnedsmidler}

\section{$\underline{\text { 5-6810 Projektmidler - levnedsmidler }}$}

Projektmidler
\begin{tabular}{|l|c|c|c|c|c|} 
Valuta & Budget 2016 & Budget 2015 & Budget 2014 & Disp./bud. 14 & Budget disp. af \\
\hline DKK & 5.046 .000 & 5.046 .000 & 4.971 .000 & $95 \%$ & EK-FJLS \\
(Levnedsmidler)
\end{tabular}

Formål Formålet er at understøtte aktiviteter i forhold til konkurrencedygtig produktion, bæredygtig ressourceforvaltning og at opretholde og videreudvikle de nordiske velfærdssamfund, dvs. arbejde for sikre og sunde fødevarer, forbrugerbeskyttelse og et højt niveau indenfor dyresundhed og dyrevelfærd. Dette gøres konkret i regi af levnedsmiddelsektorens arbejdsgrupper. Endvidere bruges midlerne til at understøtte de mere policyrettede aktiviteter i regi af embedsmandskomiteen og gennemførelse af formandskabsprogrammet.

Forvaltnings- Aktiviteter i forhold til EK-FJLS (Levnedsmidler) betjenes af tre halvtids organ arbejdsgruppesekretærer, der er ansat på hvert sit forvaltningsorgan, for henholdsvis arbejdsgruppen for ernæring og toksikologi (Fødevarestyrelsen), arbejdsgruppen for nordisk madforvaltning og forbrugerinformation (Livsmedelverket) og arbejdsgruppen for mikrobiologi, dyresundhed og dyrevelfærd (Mattilsynet).

\begin{tabular}{|c|c|c|}
\hline \multicolumn{3}{|c|}{ Mål og resultatopfølgning - Konkurrencedygtig produktion } \\
\hline 2016 - Mål & 2015 - Mål & 2014 - Opnåede resultater \\
\hline $\begin{array}{l}\text { Kosttilskud } \\
\text { Udvikle og designe en fælles } \\
\text { nordisk platform for } \\
\text { kommunikation og samarbejde } \\
\text { om kosttilskud. Det skal } \\
\text { medvirke til at forbedre kontrol } \\
\text { og beslutningsprocesser omkring } \\
\text { kosttilskud og medvirke til mere } \\
\text { sikre kosttilskud på markedet. } \\
\text { Fødevaresikkerhed } \\
\text { Videreudvikle arbejdet med } \\
\text { fødevaresikkerhed og -tryghed } \\
\text { (Food safety). } \\
\text { Tilsyn } \\
\text { Udvikle metoder for ensretning af } \\
\text { et risikobaseret tilsyn, } \\
\text { eksempelvis med fokus på de } \\
\text { kulturelle aspekter i kontrollen. } \\
\text { Derudover vil der blive afholdt et } \\
\text { tilsynsseminar om dyrevelfærd. } \\
\text { Forbrugerinformation } \\
\text { Videreudvikle arbejdet med } \\
\text { redelig håndtering og omsætning } \\
\text { samt korrekt information til } \\
\text { forbrugerne, som herved kan } \\
\text { træffe oplyste valg. }\end{array}$ & $\begin{array}{l}\text { Dyrevelfcerd } \\
\text { Videreudvikle den nordiske } \\
\text { tradition med fokus på sunde og } \\
\text { raske dyr, som opdrættes på en } \\
\text { etisk forsvarlig måde. } \\
\text { Fødevaresikkerhed } \\
\text { Videreudvikle arbejdet med } \\
\text { fødevaresikkerhed og -tryghed } \\
\text { (Food safety). } \\
\text { Tilsyn } \\
\text { Udvikle metoder for ensretning af } \\
\text { et risikobaseret tilsyn, herunder } \\
\text { fokus på tilsynsmetodik, herunder } \\
\text { koncerntilsyn. } \\
\text { Forbrugerinformation } \\
\text { Videreudvikle arbejdet med } \\
\text { redelig håndtering og omsætning } \\
\text { samt korrekt information til } \\
\text { forbrugerne, som herved kan } \\
\text { træffe oplyste valg. }\end{array}$ & $\begin{array}{l}\text { Dyrevelfærd } \\
\text { Et nordisk tilsynsseminar om } \\
\text { dyrevelfærd i } \\
\text { slagtekyllingsproduktion, og et } \\
\text { om velfærdindikatorer i praktisk } \\
\text { tilsyn fandt sted og der blev } \\
\text { identificeret områder, hvor der } \\
\text { findes grundlag for en fælles } \\
\text { nordisk strategi for påvirkning af } \\
\text { EU’s opfølgning af sin } \\
\text { dyrevelfærdsstrategi. } \\
\text { Tilsyn } \\
\text { Opfølgning på kontrolkampagnen } \\
\text { vedr. forekomst af udeklarerede } \\
\text { allergener, ikke mindst set i } \\
\text { forhold til den nye } \\
\text { informationsforordning fra EU. }\end{array}$ \\
\hline
\end{tabular}




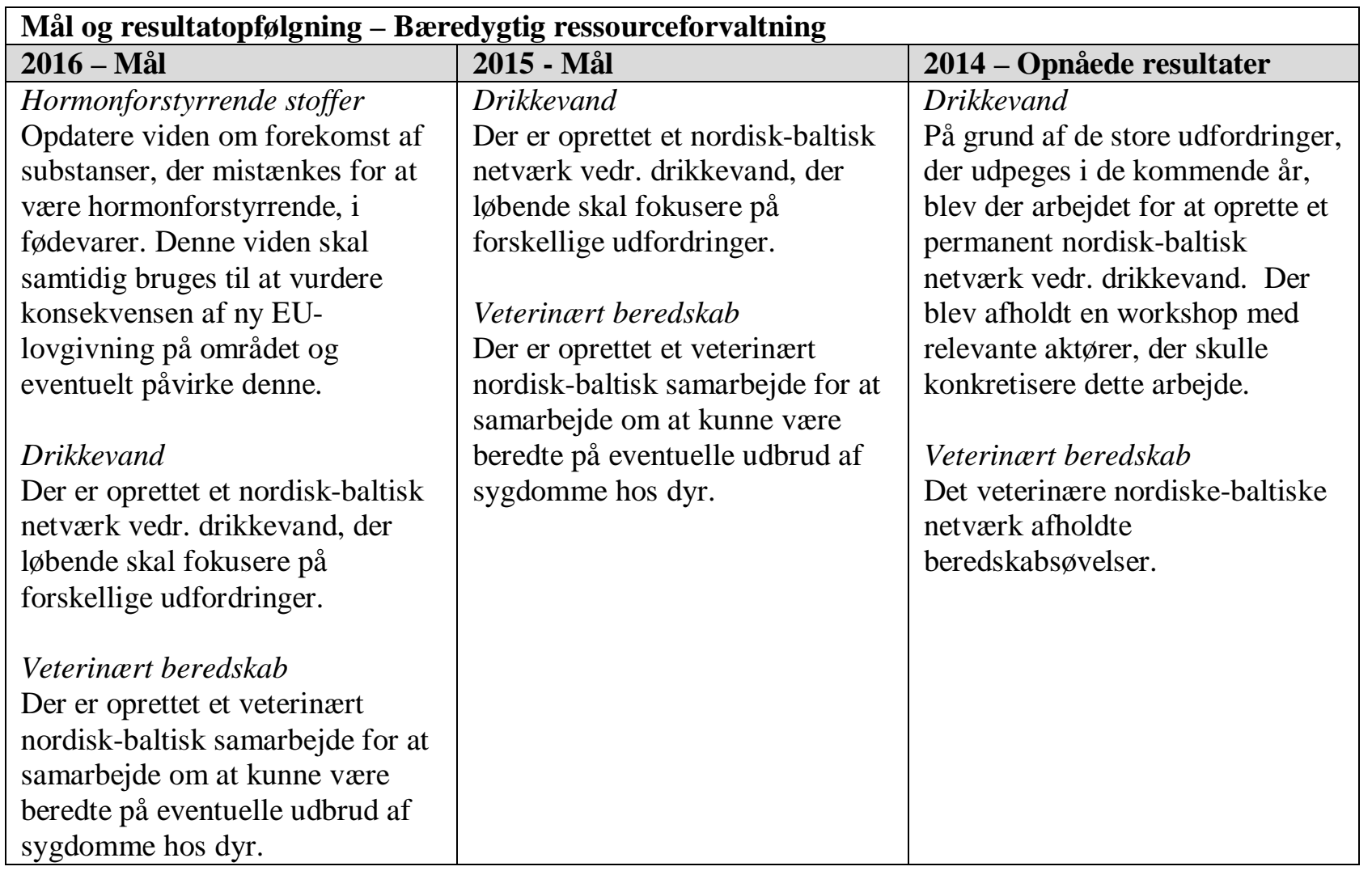

\begin{tabular}{|c|c|c|}
\hline \multicolumn{3}{|c|}{ Mål og resultatopfølgning - Opretholde og videreudvikle de nordiske velfærdssamfud } \\
\hline 2016 - Mål & 2015 - Mål & de resultater \\
\hline $\begin{array}{l}\text { Styrke og videreudvikle } \\
\text { arbejdet med at minimere } \\
\text { risiko for sunhedsskader } \\
\text { (human og dyrehelse) på } \\
\text { levnedsmiddelområdet. } \\
\text { Fokus på risiko-nytte aspektet, } \\
\text { herunder etablering af den } \\
\text { fælles nordisk beskrivelse af } \\
\text { metode/indhold i risiko-nytte } \\
\text { undersøgelser. } \\
\text { Styrke arbejdet med } \\
\text { information om } \\
\text { helsefremmende kosthold og } \\
\text { betydningen af fysisk aktivitet } \\
\text { One Health- } \\
\text { antibiotikaresistens } \\
\text { Følge op på det arbejde, der } \\
\text { blev igangsat vedr. One } \\
\text { Health i } 2014 \text { og } 2015 \text {. }\end{array}$ & $\begin{array}{l}\text { Styrke og videreudvikle arbejdet med } \\
\text { at minimere risiko for sunhedsskader } \\
\text { (human og dyrehelse) på } \\
\text { levnedsmiddelområdet. } \\
\text { Fokus på risiko-nytte aspektet } \\
\text { Styrke arbejdet med information om } \\
\text { helsefremmende kosthold og } \\
\text { betydningen af fysisk aktivitet } \\
\text { Implementere de nordiske } \\
\text { næringsrekommandationer og omsætte } \\
\text { disse til anbefalinger for } \\
\text { sammensætning af kost, samt arbejde } \\
\text { for at lette forbrugernes muligheder for } \\
\text { at træffe sundhedsmæssige gunstige } \\
\text { valg. } \\
\text { One Health - antibiotikaresistens } \\
\text { Udover det årlige møde vedr. } \\
\text { antibiotikaresistens vil der blive } \\
\text { afholdt et policymøde om One Health, } \\
\text { der skal drøfte en deklaration, der skal } \\
\text { fremlægges på møderne i MR-FJLS og } \\
\text { MR-S, for at styrke det nordiske } \\
\text { samarbejde på dette område og påvirke } \\
\text { den internationale debat. }\end{array}$ & $\begin{array}{l}\text { De nordiske næringsstofs } \\
\text { anbefalinger (NNR) } \\
\text { Den endelige udgave af NNR } \\
\text { er udgivet, og der blev igangsat } \\
\text { et arbejde vedr. } \\
\text { kommunikation af NNR. } \\
\text { Herunder anvendtes også det } \\
\text { nordiske ernæringsmærke - } \\
\text { Nøglehulsmærket, som i øvrigt } \\
\text { kan fejre } 5 \text { år som nordisk } \\
\text { mærke i } 2014 \text {. } \\
\text { One Health-- } \\
\text { antibiotikaresistens } \\
\text { Der blev afholdt det årlige } \\
\text { møde vedr. One Health - } \\
\text { antibiotikaresistens, for at } \\
\text { styrke den nordiske indsats. }\end{array}$ \\
\hline
\end{tabular}


5-6830 Nordisk handlingsplan for bedre helse og livskvalitet

\begin{tabular}{|c|c|c|c|c|c|}
\hline $\begin{array}{l}\text { Projektmidler } \\
\text { | Valuta }\end{array}$ & Budget 2016 & Budget 2015 & Budget 2014 & Disp./bud. 14 & Budget disp. af \\
\hline DKK & 547.000 & 547.000 & 539.000 & $87 \%$ & $\begin{array}{c}\text { EK-FJLS } \\
\text { (Levnedsmidler) }\end{array}$ \\
\hline
\end{tabular}

Formål $\quad$ Formålet er at implementere den nordiske handlingsplan for bedre sundhed og livskvalitet gennem kost og fysisk aktivitet som en prioriteret indsats af tværsektoriel karakter.

\begin{tabular}{|c|c|c|}
\hline \multicolumn{3}{|l|}{ Mål og resultatopfølgning } \\
\hline 2016 - Mål & 015 - Mål & 2014 - Opnåede resultater \\
\hline $\begin{array}{l}\text { Den 11. nordiske } \\
\text { ernæringskonference } \\
\text { Konferencen finder sted hvert } 4 . \\
\text { år, denne gang i Gøteborg. På } \\
\text { denne konference sættes der } \\
\text { fokus på status og det videre } \\
\text { arbejde indenfor } \\
\text { ernæringsområdet i Norden. } \\
\text { Salt } \\
\text { Øge forbrugernes viden om salt } \\
\text { og om risici ved et højt saltindtag } \\
\text { ved hjælp af et fælles nordisk } \\
\text { vidensgrundlag om salt og } \\
\text { sundhed. Projektet medtænker } \\
\text { arbejdet med det nordiske } \\
\text { ernæringsmærke, Nøglehullet. }\end{array}$ & $\begin{array}{l}\text { Monitorering af kost og motion i } \\
\text { Norden } \\
\text { Som opfølgning på den første } \\
\text { nordiske monitorering af kost og } \\
\text { fysisk aktivitet, der blev } \\
\text { gennemført i 2011, foreligger } \\
\text { resultaterne fra den anden } \\
\text { monitorering 2014. Denne gang } \\
\text { er der også den første måling af } \\
\text { alkohol og rygning medtaget. } \\
\text { Resultaterne skal give et indblik i } \\
\text { udviklingen i kost og motion - og } \\
\text { på sigt rygning og alkohol, for at } \\
\text { give et redskab til at kunne } \\
\text { påvirke udviklingen i retning af } \\
\text { en bedre velfærd for den nordiske } \\
\text { befolkning. } \\
\text { Markedsføring af usunde føde- og } \\
\text { drikkevarer rettet til børn } \\
\text { Projektet vil udvikle en fælles } \\
\text { nordisk protokol for monitorering } \\
\text { af denne form for markedsføring. }\end{array}$ & $\begin{array}{l}\text { Deltagelse i den 2. internationale } \\
\text { ernæeringskonference } \\
\text { (FAO/WHO) } \\
\text { Der blev gjort opmærksom på de } \\
\text { resultater, der er fremkommet } \\
\text { som opfølgning på det nordiske } \\
\text { samarbejde om ernæring igennem } \\
\text { de seneste år, ikke mindst med } \\
\text { lanceringen af micrositet: } \\
\text { www.nordicnutrition.org. } \\
\text { Monitorering af kost og motion i } \\
\text { Norden } \\
\text { I den nordiske monitorering for } \\
\text { kost og motion måles status } \\
\text { blandt børn 7-12 år, samt voksne } \\
\text { 18-65 år. Der blev afholdt et } \\
\text { seminar med fokus på, hvordan } \\
\text { de unge kan blive bedre til at } \\
\text { deltage i monitoreringen, således } \\
\text { at de også kan deltage i } \\
\text { monitoreringen med succes. }\end{array}$ \\
\hline
\end{tabular}

\section{Skovbrug}

5-6310 Projektmidler - Skovbrug

Projektmidler
\begin{tabular}{|l|c|c|c|c|c|} 
Valuta & Budget 2016 & Budget 2015 & Budget 2014 & Disp./bud. 14 & Budget disp. af \\
\hline DKK & 306.000 & 306.000 & 301.000 & $50 \%$ & $\begin{array}{c}\text { EK-FJLS } \\
\text { (Skovbrug) }\end{array}$
\end{tabular}

Formål Formålet er at understøtte aktiviteter i forhold til konkurrencedygtig produktion, bæredygtig ressourceforvaltning og at opretholde og videreudvikle de nordiske velfærdssamfund. Arbejdet inden for EK-FJLS (Skovbrug) sker i tæt relation til SNS, NordGen og arbejdet omkring bioøkonomi. Komiteen råder over en mindre budgetpost, 
som anvendes til at understøtte de mere policyrettede aktiviteter i regi af embedsmandskomiteen og gennemførelse af formandskabsprogrammet. Budgetposten understøtter det eksisterende samarbejde på nordiske skovbrugspolitiske område karakteristeret ved landenes engagement i netværk inden for området.

\begin{tabular}{|c|c|c|}
\hline \multicolumn{3}{|l|}{ Mål og resultatopfølgning- } \\
\hline 2016 - Mål & 2015 - Mål & 2014 - Opnåede resultater \\
\hline $\begin{array}{l}\text { Fokusområderne for } 2016 \text { vil } \\
\text { være i relation til bæredygtig } \\
\text { vækst og bioøkonomi. }\end{array}$ & $\begin{array}{l}\text { Fortsat arbejde med } \\
\text { strategiarbejdet med fokus på: } \\
\text { Formulering af, godkendelse af } \\
\text { og kommunikation af nye policy } \\
\text { prioriteter i det nordiske } \\
\text { skovpolitiske samarbejde for } \\
\text { perioden 2015-2020. } \\
\text { At styrke det nordiske } \\
\text { skovpolitiske samarbejde inden } \\
\text { for eksisterende samarbejder, } \\
\text { netværk og strukturer. }\end{array}$ & $\begin{array}{l}\text { Under det islandske formandskab } \\
\text { blev der igangsat et strategiarbejde } \\
\text { med det formål } \\
\text { at udvikle policy prioriteringer og } \\
\text { rekommandationer for det nordiske } \\
\text { skovpolitiske samarbejde i perioden } \\
\text { 2015-2020. Arbejdet blev delt op i } \\
\text { følgende afsnit: } \\
\text { Opfølgninger på resultaterne af } \\
\text { arbejdet med skovministrenes Selfoss } \\
\text { deklaration om bæredygtig skovbrug. } \\
\text { Formulering af, godkendelse af og } \\
\text { kommunikation af nye policy } \\
\text { prioriteter i det nordiske } \\
\text { skovpolitiske samarbejde for } \\
\text { perioden 2015-2020. At styrke det } \\
\text { nordiske skovpolitiske samarbejde } \\
\text { inden for eksisterende samarbejder, } \\
\text { netværk og strukturer. } \\
\text { Under året 2014 blev den første del } \\
\text { afsluttet med rapport der findes på: } \\
\text { http://norden.diva- } \\
\text { portal.org/smash/record.jsf?pid=diva2\%3 } \\
\text { A764729\&dswid=7743 }\end{array}$ \\
\hline
\end{tabular}

\section{5-6581 Samnordisk skogsforskning (SNS)}

Programlignende aktiviteter

\begin{tabular}{|l|c|c|c|c|c|} 
Valuta & Budget 2016 & Budget 2015 & Budget 2014 & Disp./bud. 14 & Budget disp. af \\
\hline DKK & 5.561 .000 & 5.561 .000 & 5.479 .000 & $100 \%$ & SNS
\end{tabular}

Formål

SamNordisk Skovforskning (SNS) skal skabe nordisk nytte ved (1) at fremme forskningssamarbejde og netværk for et bæredygtigt skovbrug og anvendelse af skovressourcer, (2) at give pålidelige, relevante og aktuelle forskningsfaglige bidrag til det nordiske skovpolitiske policy-arbejde, (3) at være en betydelig aktør i tværfaglige nordiske udfordringer inden for skovsektoren og (4) styrke Nordens position indenfor skovforskning i europæisk og international sammenhæng.

Forvaltnings- Sveriges Lantbruksuniversitet organ

\begin{tabular}{|c|c|c|}
\hline \multicolumn{3}{|l|}{ Mål og resultatopfølgning } \\
\hline 2016 - Mål & 2015 - Mål & 2014 - Opnåede resultater \\
\hline $\begin{array}{l}\text { Det primære mål er at } \\
\text { færdiggøre strategiarbejdet }\end{array}$ & $\begin{array}{l}\text { Styrke forskning af fælles nordisk } \\
\text { interesse for en bæredygtig }\end{array}$ & $\begin{array}{l}\text { Under } 2014 \text { bidrog SNS med stöd } \\
\text { till } 11 \text { nätverk og der avslutades }\end{array}$ \\
\hline
\end{tabular}




\begin{tabular}{|l|l|l|}
\hline $\begin{array}{l}\text { New Forest Solutions og } \\
\text { aflevere det på MR-FJLS i } \\
2016 .\end{array}$ & skovforvaltning. & ett projekt. Inga nya projekt \\
& Give forskningsbaseret policy- & startade under 2014 med \\
& föregående års beslut om en \\
& fremtining for en bæredygtig & större satsning i utlysningen \\
& Styrke Nordens position indenfor \\
indför 2015, detta på grund av får & få och kvalitetsmässigt \\
& undermåliga ansökningar. \\
& international sammenhæng. & Formidle forskningsresultater og \\
& udvikle kommunikationsaktiviteter & I tillägg till tidigare vanliga \\
& kommunikationsvägar har under \\
& fom øger samspillet mellem & 2014 stort arbete lagts ned på att \\
& forsning, erhverv og politik. & $\begin{array}{l}\text { implementera den tvåsidiga mall } \\
\text { för ”policy briefs”. }\end{array}$ \\
\hline
\end{tabular}




\section{Jämställdhet}

\section{Generel indledning}

Formål og Det nordiska jämställdhetssamarbetet inleddes 1974 och ministerrådet för jämställdhet Fakta (MR-JÄM) etablerades 1980. De nordiska ländernas samarbete kring jämställdhetsfrågor drivs av en gemensam nordisk vision om ett jämställt Norden med lika möjligheter, rättigheter och skyldigheter för alla invånare oberoende av kön.

\section{Strategiske målsætninger 2016}

Ministerrådets resultater i 2014
Samarbetet baserar sig på samarbetsprogram, Tillsammans för jämställdhet - ett starkare Norden. Programmet gäller för 2015-2018 och innehåller två övergripande teman: det offentliga rummet och välfärd och innovation. Dessutom har programmet två tvärgående teman: män och jämställdhet och hållbar utveckling med ett fokus på mångfald. Samarbetsprogrammet konkretiseras genom årliga sektorsprogram och budgeten.

Under 2016 fortsätter MR-JÄM genomföra samarbetsprogrammet Tillsammans för jämställdhet - ett starkare Norden. Sektorn kommer särskilt att fokusera på nolltolerans mot könsrelaterat våld samt jämställdhet och könsperspektiv i media.

Samarbetsprogrammet Jämställdhet skapar ett hållbar samhälle - Nordiskt jämställdhetspolitiskt samarbete 2011-2014. Det isländska ordförandeskapet prioriterade 40-års jubileumet för det nordiska jämställdhetssamarbetet, nolltolerans mot könsrelaterat våld, jämställdhet på arbetsmarknaden och män och jämställdhet. Utöver detta fokuserade sektorn på jämställdhet i Västnorden.

40-års jubileumet fokuserade på jämställdhet och utbildning, män och jämställdhet samt barn och unga och kulminerade i en jubileumskonferens i Reykjavik för att diskutera samarbetets resultat och framtidsmål, med fokus på jämställdhet på arbetsmarknaden, utbildning och mäns och pojkars ökade deltagande i jämställdhetsarbetet samt demokratins status utifrån kvinnors politiska deltagande. I en paneldebatt som ordnades i samarbete med Ungdomens Nordiska Råd om ungdomars framtidssyn i jämställdhetsfrågor betonades att det nordiska samarbetet gett goda resultat under de senaste årtiondena och att samarbetet med Västnorden behöver stärkas och att det måste garanteras att samarbetet har en internationell effekt. Konferensens konklusion var att det är viktigt att öka mäns och ungdomens deltagande i jämställdhetsdebatten och garantera att olika synpunkter i den offentliga debatten.

Könsrelaterat våld är ett folkhälsoproblem som är systematiskt, utbrett och tar sig många former. För att uppnå resultat är det nödvändigt att olika yrken samarbetar, att problem diagnostiseras på ett tidigt stadium och att det måste finnas en handlingsplan. För att förebygga problemet krävs inte minst en ökad kunskap och en satsning på jämställdhetsundervisning i allmänhet. Det är viktigt att öka det nordiska samarbetet inom detta område, vi kan lära oss mycket av varandra och bl.a. göra en gemensam granskning av hur det går att uppfylla Istanbulkonventionen när den antagits. Det var konklusionerna vid ett expertsymposium om metoder som gett bäst resultat i kampen mot könsrelaterat våld med utgångspunkt i Europarådets Istanbulkonvention.

Jämställdhetssektorn visade sitt internationella engagemang genom närvaro vid FN:s kvinnokommission i mars 2014 som överordnat fokuserade på FN:s milleniemål. MRJÄM arrangerade en ministerpaneldebatt om utbildning som en väg till jämställdhet och ett stärkande av kvinnors situation. Ministrarna diskuterade bl.a. hur myndigheters beslut och direkta åtgärder kan uppmuntra flickor och kvinnor att utbilda sig och arbeta 
inom naturvetenskapliga och tekniska yrken och öka antalet kvinnor i ledande positioner. MR-JÄM arrangerade också ett expertsymposium jämställdhetsutmaningar och hinder inom utbildningssystemet och på arbetsmarknaden.

MR-JÄM stödde Nordiskt forum 2014 i Malmö. Nordiskt forum 2014 arrangerades av organisationer ur den nordiska kvinnorörelsen och besöktes av ca 20000 personer. MRJÄM var i en paneldebatt om det nordiska jämställdhetssamarbetets utveckling under 40 år och framtida planer, överens om att det nordiska samarbetet ökat kunskapen om jämställdhetsfrågor och fört länderna närmare målsättningen om nordiska samhällen av välfärd, rättvisa och demokrati. Ministrarna uppmärksammade vikten av att Norden gemensamt deltar aktivt och bär ansvar på den internationella arenan. De nordiska jämställdhetsministrarna deltog även vid avslutningsceremonin där de tog emot slutdokumentet där kvinnorörelsen i Norden påminner myndigheterna om de åtaganden som de antog när de undertecknade handlingsplanen från FN:s 4.e kvinnokonferens i Peking 1995.

MR-JÄM bidrog till en tvådagars konferens om jämställdhet i Arktis där kvinnors och mäns förhållanden i de arktiska områdena i ett större sammanhang granskades och intresse riktades bl.a. mot tillgången och bestämmanderätten över naturtillgångar, könens deltagande i beslutsfattande och politik, demografisk utveckling, och säkerhet och allmän välfärd samt könsideal i de arktiska områdena. Konferensen följs upp med en rapport och uppbyggande av ett samarbetsnät mellan forskare och andra aktörer på de arktiska områdena, t.ex. om ett ökat deltagande av kvinnor i politik och beslutsfattande, hälso- och sjukvårdsfrågor, socialtjänst, distansundervisning, kamp mot våld m.m., inleds.

"Part-Time Work in the Nordic Region II" fokuserar på de bakomliggande orsakerna till varför kvinnor arbetar deltid mer än män. Rapporten är skriven av

Arbeidsforskningsinstittutet i Norge, med bidrag från forskare i alla nordiska länder. En grupp forskare med nordisk bredd har fungerat som stöd för. Rapporten beskriver den forskning som finns kring följande tre huvudförklaringar till varför kvinnor arbetar deltid nämligen hälsorelaterade förklaringar, balansering av familje- och arbetsliv eller inte möjligt att få heltidsarbete. Rapporten diskuterades under en konferens som arrangerades i samma förbindelse som en likalönskonferens.

Utan myndigheters policyutformning och samarbete med arbetsmarknadsparternas organisationer skulle det ta mycket lång tid att upplösa könsarbetsdelningen på arbetsmarknaden och utjämna löneskillnaderna konkluderade deltagarna i en likalönskonferens som diskuterade möjliga framgångsrika vägar för att utjämna kvinnors och mäns ställning på arbetsmarknaden och vilka åtgärder som effektivt minskat könsbundna löneskillnader. Lag - och avtalsbestämmelser behövs men man måste också uppmärksamma indirekt diskriminering som bl. a. visar sig i ett ogenomskinligt och komplicerat överklagandesystem och könsdiskriminering när det gäller antalet som väljer deltidsarbete för att kunna harmoniera familje- och arbetsliv och hur föräldraledigheten tas ut. Könsbunden lönediskriminering är ett mångfacetterat problem som bl. a. bygger på könsbundna utbildnings- och yrkesval konstaterade specialister och representanter för arbetsmarknadsparternas organisationer från hela Norden. En attitydförändring är nödvändig. Arbetsmarknaden måste vara attraktiv för båda könen och glesbygder måste kunna erbjuda välutbildade kvinnor välavlönade arbeten för att stoppa trenden med att unga familjer flyttar iväg. Det upprepades att arbetsmarknadsparternas organisationer bär ansvar och att det är nödvändigt att finansiera forskning om hur avtal sluts på arbetsmarknaden. Konklusionen av diskussionen är att jämställdhet på arbetsmarknaden är mycket aktuellt ämne i Norden och Europa - det nordiska nätverket för likalön är viktig redskap för att förmedla diskussionen och utvecklingen i länderna. 
Nordic Gender and Media Forum, http://www.nordicgenderandmediaforum.se/, var ett projekt som samlade experter och intressenter till diskussioner om jämställdhet i film, reklam, datorspel och journalism. Inom ramen för projektet genomfördes fyra diskussionstillfällen, en konferens i Bergen i samband med mediedagarna där och en boklancering i samarbete med European Institute for Gender Equality (EIGE) i Vilnius. En bokantologi Making Change var ett av projektets slutprodukter. Projektet har lyft fram ojämställdhet och missrepresentation i media genom kunskaps- och erfarenhetsutbyte som även väckt internationellt intresse bland annat i samband med FN:s kvinnokommission CSW (Commission on the Status of Women).

Under 2014 togs även det nya samarbetsprogrammet fram. I processen deltog Nordiska rådet, facksektorerna i Nordiska ministerrådet hördes och såväl organisationer som individer i Norden hade möjlighet att ge inspel via en öppen remissrunda som arrangerades av samarbetsorganet NIKK. Tillsammans för jämställdhet - ett starkare Norden, gäller för perioden 2015-2018.

\begin{tabular}{|c|c|c|c|c|c|}
\hline & \multirow{2}{*}{$\begin{array}{r}\text { Budget } \\
2016\end{array}$} & \multirow{2}{*}{$\begin{array}{r}\text { Budget } \\
2015\end{array}$} & \multicolumn{2}{|c|}{ Difference } \\
\hline & & & & $+/-$ & $\%$ \\
\hline \multicolumn{2}{|c|}{ MR-Jäm (TDKK) } & 8.873 & 8.873 & $\overline{0}$ & $0,0 \%$ \\
\hline & Projektmedel & 8.873 & 8.873 & 0 & $0,0 \%$ \\
\hline $6-4410$ & Projektmedel - Jämställdhet & 3.493 & 3.493 & 0 & $0,0 \%$ \\
\hline $6-4420$ & MR-JÄMs stödordning & 2.842 & 2.842 & 0 & - \\
\hline $6-4480$ & Nordisk information för kunskap om kön (NIKK) & 2.538 & 2.538 & 0 & $0,0 \%$ \\
\hline \multicolumn{2}{|c|}{ Opdelt på kategorier } & 8.873 & 8.873 & $100 \%$ & $100 \%$ \\
\hline & Projektmidler & 6.335 & 6.335 & $71,4 \%$ & $71,4 \%$ \\
\hline & Programlignende aktiviteter & 2.538 & 2.538 & $28,6 \%$ & $28,6 \%$ \\
\hline
\end{tabular}

\section{6-4410 Projektmedel - Jämställdhet}

Projektmidler
\begin{tabular}{|l|c|c|c|c|c|} 
Valuta & Budget 2016 & Budget 2015 & Budget 2014 & Disp./bud. 14 & Budget disp. af \\
\hline DKK & 3.493 .000 & 3.493 .000 & 6.379 .000 & $100 \%$ & MR/Äk-JÄM
\end{tabular}

Formål Jämställdhetssektorns projektmedel syftar till att verkställa Nordiska ministerrådets samarbetsprogram för jämställdhetssamarbetet: Tillsammans för jämställdhet - ett starkare Norden.

Medlen indelas i tre delar:

1. genomförande av det årliga sektorsprogrammet

2. ad hoc-initiativ (politiska prioriteringar)

3. sektorspecifik administration

\begin{tabular}{|c|c|c|}
\hline \multicolumn{3}{|l|}{ Mål og resultatopfølgning } \\
\hline 2016 - Mål & 2015 - Mål & 2014 - Opnåede resultater \\
\hline $\begin{array}{l}\text { Jämställdhetssektorn syftar under } \\
\text { året att arbeta med } \\
\text { samarbetsprogrammets tema }\end{array}$ & $\begin{array}{l}\text { Fokus under år } 2015 \text { är att } \\
\text { igångsätta arbetet med att } \\
\text { verkställa det nya }\end{array}$ & $\begin{array}{l}\text { Budgetpostens medel användes } \\
2014 \text { för att förverkliga } \\
\text { samarbetsprojekt inom temana }\end{array}$ \\
\hline
\end{tabular}




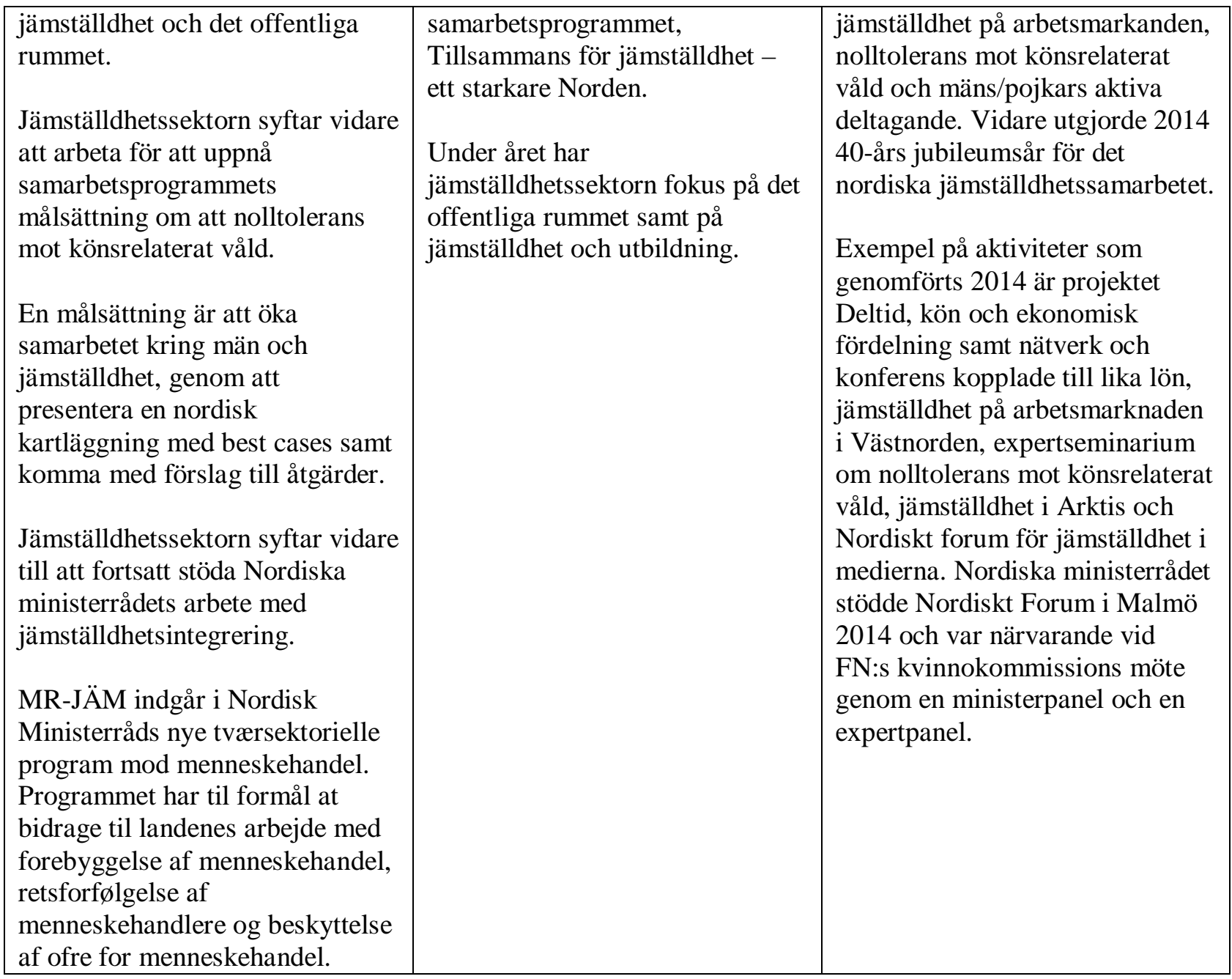

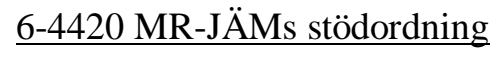

Projektmidler

\begin{tabular}{|l|c|c|c|c|c|} 
Valuta & Budget 2016 & Budget 2015 & Budget 2014 & Disp./bud. 14 & Budget disp. af \\
\hline DKK & 2.842 .000 & 2.842 .000 & 0 & $0 \%$ & MR/Äk-JÄM
\end{tabular}

Formål Stödordningen skall stimulera nordiskt samarbete på jämställdhetsområdet inom ramen för jämställdhetsministrarnas samarbetsprogram och dess prioriteringar. Stödordningen syftar till att stöda projekt som inbegriper såväl nordiskt mervärde som ett jämställdhetspolitiskt mervärde. Stödordningens riktlinjer beslutas av ÄK-JÄM.

\begin{tabular}{|c|c|c|}
\hline \multicolumn{3}{|l|}{ Mål og resultatopfølgning } \\
\hline 2016 - Mål & 2015 - Mål & 2014 - Opnåede resultater \\
\hline $\begin{array}{l}\text { MR-JÄMs stödordning stimulerar } \\
\text { nordiskt samarbete genom } \\
\text { projektstöd för aktiviteter som } \\
\text { inbegriper nordiskt och } \\
\text { jämställdhetspolitiskt mervärde. }\end{array}$ & $\begin{array}{l}\text { MR-JÄMs stödordning ska för } \\
\text { tredje året stimulera nordiskt } \\
\text { samarbete om jämställdhet. MR- } \\
\text { JÄMs samarbetsprogram } \\
\text { Tillsammans för jämställdhet - } \\
\text { ett starkare Norden, är } \\
\text { utgångstpunkten för } \\
\text { stödordningen. }\end{array}$ & $\begin{array}{l}\text { MR-JÄMs stödordning andra } \\
\text { utlysning medverkade till att } \\
\text { förverkliga nordiskt } \\
\text { jämställdhetssamarbete inom } \\
\text { ramen för } \\
\text { jämställdhetsministrarnas } \\
\text { prioriteringar om jämställdhet på } \\
\text { arbetsmarknaden, jämställdhet } \\
\text { och utbildning, könsrelaterat våld }\end{array}$ \\
\hline
\end{tabular}




\begin{tabular}{|l|l|l|}
\hline & $\begin{array}{l}\text { och kön, etnicitet och } \\
\text { jämställdhet. Totalt tretton } \\
\text { projekt beviljades medel av 41 } \\
\text { ansökningar. }\end{array}$ \\
\hline
\end{tabular}

$\underline{\text { 6-4480 Nordisk information för kunskap om kön (NIKK) }}$

Programlignende aktiviteter

\begin{tabular}{|l|c|c|c|c|c|} 
Valuta & Budget 2016 & Budget 2015 & Budget 2014 & Disp./bud. 14 & Budget disp. af \\
\hline DKK & 2.538 .000 & 2.538 .000 & 2.540 .000 & $100 \%$ & MR/Äk-JÄM
\end{tabular}

Formål $\quad$ NIKK, Nordisk information för kunskap om kön, är jämställdhetsministrarnas samarbetsorgan med främsta syfte att förmedla och synliggöra nordisk jämställdhetspolitik.

Forvaltnings- $\quad$ Nationella sekretariatet för genusforskning (slutgiltigt beslut i MR-JÄM hösten 2015) organ

\begin{tabular}{|c|c|c|}
\hline \multicolumn{3}{|l|}{ Mål og resultatopfølgning } \\
\hline 2016 - Mål & 2015 - Mål & 2014 - Opnåede resultater \\
\hline $\begin{array}{l}\text { NIKKs huvudsakliga syften är att } \\
\text { synliggöra och förmedla nordisk } \\
\text { jämställdhetspolitik och praktik, } \\
\text { samt att fungera som } \\
\text { projektsekretariat för MR-JÄM. }\end{array}$ & $\begin{array}{l}2015 \text { är sista verksamhetsår inom } \\
\text { ramen för NIKKs nuvarande } \\
\text { mandat. Under året skall beslut } \\
\text { fattas om NIKK efter } 2015 \text {. }\end{array}$ & $\begin{array}{l}\text { Under } 2014 \text { prioriterade NIKK } \\
\text { att synliggöra } \\
\text { jämställdhetssektorns } \\
\text { arrangemang, att vidareutveckla } \\
\text { webbplatsen och nyhetsbrev och } \\
\text { administration av MR-JÄMs } \\
\text { stödordning. }\end{array}$ \\
\hline
\end{tabular}




\section{Närings-, Energi- och Regionalpolitik}

\section{Generel indledning}

Formål og Ministerrådet för Näring-, energi- och regionalpolitik (MR-NER) arbetar för att säkra Fakta tillväxt och utveckling inom de nordiska länderna genom att utveckla ett innovativt, konkurrenskraftigt och hållbart näringsliv samt att bidra till att säkra en stabil tillgång till hållbara energikällor och en hållbar regional utveckling som främjar en grön tillväxt i Norden. MR-NER skall bidra till att skapa ökad konkurrensförmåga, ökad innovation och avskaffande av gränshinder för människor och företag inom regionen.

\section{Strategiske målsætninger 2016}

Erhvervssektoren i Norden skal udvikles til en foregangsregion inden for innovation, entreprenørskab, finansiering mm. og skabe bæredygtig vækst. Derfor har erhvervssektoren igangsat 5 nye fyrtårnsprojekter under samarbejdsprogrammet for erhvervs- og innovationspolitikken 2014-17: 1) Nordisk partnerskab for entreprenørskab og finansiering, 2) Innovative nordiske digitale løsninger, 3) Nordic Built Cities, 4) Innovative nordiske velfærdsløsninger, og 5) Nordisk partnerskab for ekspansion af kulturelle og kreative virksomheder. Og endelig vil erhvervssektoren gennem Nopef aktivt samarbejde og udveksle information med både nationale og nordiske erhvervsorganisationer. Det er et mål, at Nopef bevilliger finansiering til 60 kvalificerede forstudieprojekter, og at $50 \%$ af disse afsluttede forstudieprojekter medfører eksport.

Energisektoren skal, via sit energipolitiske samarbejdsprogram for 2014-17, bidrage til det grønne vækstsamfund med stabil energiforsyning og bæredygtig energi til gavn for velfærden i de nordiske lande. Det nordiske energisamarbejde skal være et redskab til yderligere harmonisering af det nordiske elmarked og markedsføring af nordiske styrkepositioner på den globale arena. Der skal fortsat arbejdes målrettet med: 1) Velfungerende energimarkeder og klimavenlige energisystemer, 2) Energieffektivisering 3) Brug af vedvarende energikilder 4) Udvikling af mere miljøvenlige energikilder til transport på sø, land, i luft og i fiskerisektoren. Der arbejdes på at igangsætte en strategisk gennemlysning af sektoren i 2016.

Regionalsektorn skall genomföra och driva det nordiska regionalpolitiska samarbetet framåt genom att avsluta satsningar och initiativ inom det nordiska regionalpolitiska samarbetsprogrammet 2013 - 2016. Programmet ska 1) Bidra till en regionalt hållbar välfärdsutveckling, 2) Främja en hållbar regional utveckling i Arktis, samt 3) Stimulera en grön tillväxt i alla regioner. Arbetet genomförs i fyra arbetsgrupper under ÄK-R inom 1) Välfärd/demografi, 2) Arktis, 3) Grön tillväxt - innovation, 4) Grön tillväxt - plansamarbete och hållbara stadsregioner.

Nordregios verksamhet inom bl.a. riktade forskningsinsatser skall medverka till en hållbar tillväxt och ett mer konkurrenskraftigt och innovativt Norden. Regionalsektorns stöd till tolv Gränskommittéer skall bidra till ett välfungerande och fruktbart gränsregionalt samarbete, samt att reducera gränshinder och att utveckla hållbara gränsregioner. Regionalsektorn skall ta fram en västnordisk utvecklingsstrategi som ska bidra till att stärka och utveckla samarbetet inom regionalområdet i den nordatlantiska regionen (Grönland, Island, Färöarna och Kust-Norge). Nordatlantiska samarbetet (NORA) skall utveckla en attraktiv plattform för nordiskt samarbete med grannländerna, särskilt nordens grannar i väst (Kanada, Skottland och Irland).

Regionalsektorn har, som en del av initiativet Nordisk statistik inom prioriteringsbudgeten, för avsikt att utveckla en regionalt profilerad nordisk databas med gränsöverskridande statistik om befolkning och arbetsmarknad i gränsregioner på basen 
Ministerrådets resultater i 2014 av det tidigare StatNord-projektet. Databasen ska innehålla aktuell, anpassad och jämförbar statistik från båda sidor av en nationsgräns som synliggör mobiliteten mellan de nordiska länderna.

Erhvervssektoren har udarbejdet et nyt nordisk samarbejdsprogram for innovation og erhvervspolitikken 2014-2017, der sikrer en fokusering af den erhvervspolitiske indsats på nordiske styrkepositioner. Man har gennemført og afsluttet visse af fyrtårnsprojekterne fra det tidligere samarbejdsprogram 2011-13. Fx er fyrtårnsprojektet Nordic Built på i alt 200 MNOK blevet gennemført. Endvidere har erhvervssektoren med samarbejdsprogrammet for 2014-2017 igangsat fem nye fyrtårnsprojekter: Nordisk partnerskab for entreprenørskab og finansiering, Innovative nordiske digitale løsninger, Nordic Built Cities, Innovative nordiske velfcerdsløsninger, og Nordisk partnerskab for ekspansion af kulturelle og kreative virksomheder.

Energisektoren afsluttede i 2014 projektet om mulighederne for en fælles nordisk indsats til fremme af forbrugerfleksibiliteten. Det viste sig, at det på nuværende tidspunkt giver mere mening at gennemføre nationale initiativer til fremme af forbrugerfleksibilitet fremfor at igangsætte et fælles nordisk initiativ til fremme af forbrugerfleksibiliteten på det fælles nordiske elmarked. Det skyldes, at potentialet for forbrugerfleksibilitet er for forskelligt i de enkelte lande til, at et fælles initiativ kan svare sig. Elmarkedsgruppen videregav projektet til NordReg (Nordic Energy Regulators), som vil arbejde videre med problematikken. . Det islandske formandskab igangsatte Nordbio projektet, hvor energisektoren er involveret i Marina projektet omkring biofuels i fiskerisektoren.

Regionalsektorn har under 2014 fortsatt sitt arbete med att genomföra satsningar och initiativ inom ramen för det regionalpolitiska samarbetsprogrammet 2013 - 2016. De fyra arbetsgrupper som initierats för genomförande av samarbetsprogrammet har fortsatt sitt arbete. En revidering av Vestnordenfondens stadgar har genomförts som resultat av den analys som genomförts av ÄK-R. 


\begin{tabular}{|c|c|c|c|c|c|}
\hline & \multirow{2}{*}{$\begin{array}{r}\text { Budget } \\
2016\end{array}$} & \multirow{2}{*}{$\begin{array}{r}\text { Budget } \\
2015\end{array}$} & \multicolumn{2}{|c|}{ Difference } \\
\hline & & & & $+/-$ & $\%$ \\
\hline \multicolumn{2}{|c|}{ Sum MR-NER (TDKK) } & 132.686 & 132.686 & $\mathbf{0}$ & $0,0 \%$ \\
\hline & Näring & 89.619 & 89.619 & 0 & $0,0 \%$ \\
\hline $7-5140$ & Projektmidler Näring & 1.986 & 1.986 & 0 & $0,0 \%$ \\
\hline \multirow[t]{2}{*}{$7-5280$} & Nopef & 15.162 & 15.162 & 0 & $0,0 \%$ \\
\hline & Institutioner - Näring & 72.471 & 72.471 & 0 & $0,0 \%$ \\
\hline \multirow[t]{2}{*}{$7-5180$} & Nordisk Innovation (NI) & 72.471 & 72.471 & 0 & $0,0 \%$ \\
\hline & Energi & 10.582 & 10.582 & 0 & $0,0 \%$ \\
\hline \multirow[t]{2}{*}{$7-5141$} & Projektmidler Energi & 4.130 & 4.130 & 0 & $0,0 \%$ \\
\hline & Institutioner - Energi & 6.452 & 6.452 & 0 & $0,0 \%$ \\
\hline \multirow[t]{2}{*}{$7-3220$} & Nordisk Energiforskning (NEF) & 6.452 & 6.452 & 0 & $0,0 \%$ \\
\hline & Regional & 32.485 & 32.485 & 0 & $0,0 \%$ \\
\hline $7-5143$ & $\begin{array}{l}\text { Impl. af samarbetsprogram, demografi, arbetsgrupper } \\
\text { och projekmedel - Regional }\end{array}$ & 5.320 & 5.320 & 0 & $0,0 \%$ \\
\hline $7-5151$ & NORA & 6.624 & 6.624 & 0 & $0,0 \%$ \\
\hline \multirow[t]{2}{*}{$7-5160$} & Grenseregionalt samarbeid & 9.287 & 9.287 & 0 & $0,0 \%$ \\
\hline & Institutioner - Regional & 11.254 & 11.254 & 0 & $0,0 \%$ \\
\hline $7-6180$ & Nordregio & 11.254 & 11.254 & 0 & $0,0 \%$ \\
\hline \multicolumn{2}{|c|}{ Opdelt på kategorier } & 132.686 & 132.686 & $100 \%$ & $100 \%$ \\
\hline & Projektmidler & 11.436 & 11.436 & $8,6 \%$ & $8,6 \%$ \\
\hline & Programlignende aktiviteter & 24.449 & 24.449 & $18,4 \%$ & $18,4 \%$ \\
\hline & Institutioner & 90.177 & 90.177 & $68,0 \%$ & $68,0 \%$ \\
\hline & Organisationsbidrag & 6.624 & 6.624 & $5,0 \%$ & $5,0 \%$ \\
\hline
\end{tabular}

\section{Näring}

\section{7-5140 Projektmedel - Näring}

Projektmidler
\begin{tabular}{|l|c|c|c|c|c|} 
Valuta & Budget 2016 & Budget 2015 & Budget 2014 & Disp./bud. 14 & Budget disp. af \\
\hline DKK & 1.986 .000 & 1.986 .000 & 1.957 .000 & $90 \%$ & EK-N
\end{tabular}

Formål Projektmidlerne skal anvendes til at gennemføre projekter, analyser og andre aktiviteter, som bidrager til nordisk nytte og udviklingen af et innovativt, konkurrencedygtigt og bæredygtigt erhvervsliv i Norden, herunder gennem tværsektorielle projekter.

I overensstemmelse med det af MR-NER/EK-N besluttede rammeprogram er følgende mål fastlagt for 2016.

\begin{tabular}{|c|c|c|}
\hline \multicolumn{3}{|l|}{ Mål og resultatopfølgning } \\
\hline 2016 - Mål & 2015 - Mål & 2014 - Opnåede resultater \\
\hline $\begin{array}{l}\text { Øget viden i MR-N om de } \\
\text { nordiske landes udfordringer } \\
\text { inden for innovation og } \\
\text { erhvervspolitk. } \\
\text { Øget innovation, styrket } \\
\text { konkurrenceevne og } \\
\text { bæredygtighed i nordiske }\end{array}$ & $\begin{array}{l}\text { Der gennemføres } 5 \\
\text { fyrtårnsprojekter, der vil } \\
\text { understøtte satsningerne i } \\
\text { samarbejdsprogrammet for } \\
\text { erhvervs- og innovationspolitikken } \\
\text { 2014-17. } \\
\text { Der gennemføres en evaluering af }\end{array}$ & $\begin{array}{l}\text { Forprojekterne til } \\
\text { fyrtårnsprojekter blev gennemført } \\
\text { og pilotprojekterne udmøntet i de } \\
\text { egentlige fyrtårnsprojekter: } \\
\text { Nordisk partnerskab for } \\
\text { entreprenørskab og finansiering, } \\
\text { Innovative nordiske digitale } \\
\text { løsninger, Nordic Built Cities, }\end{array}$ \\
\hline
\end{tabular}




\begin{tabular}{|c|c|c|}
\hline $\begin{array}{l}\text { virksomheder gennem } \\
\text { projekter med tydelig } \\
\text { fællesnordisk merværdi. }\end{array}$ & $\begin{array}{l}\text { KreaNord og en } \\
\text { afslutningskonference. } \\
\text { Der gennemføres danske } \\
\text { formandskabsinitiativer under } \\
\text { temaerne vcekst, velfcerd, værdier } \\
\text { og det blå arktis. } \\
\text { Evalueringer af tidligere initiativer } \\
\text { for at styrke den fremadrettede } \\
\text { indsats og skabe synlige resultater } \\
\text { samt målbare effekter. Dette skal } \\
\text { ses i sammenhæng med } \\
\text { moderniseringsreformen. } \\
\text { Der skal følges op på evalueringen } \\
\text { af NI, hvilket skal sikre } \\
\text { implementeringen af } \\
\text { anbefalingerne i evalueringen. }\end{array}$ & $\begin{array}{l}\text { Innovative nordiske } \\
\text { velfcrdsløsninger, og } \\
\text { Nordisk partnerskab for } \\
\text { ekspansion af kulturelle og } \\
\text { kreative virksomheder. } \\
\text { Rapporten Nordic Exports of } \\
\text { Goods and Exporting Enterprises } \\
\text { blev lanceret og en konference } \\
\text { afholdt på baggrund af rapporten } \\
\text { for at skabe bedre videns grundlag } \\
\text { for policy inden for } \\
\text { eksportområdet. } \\
\text { Et fælles kontor for nordiske } \\
\text { grønne virksomheder blev } \\
\text { etableret i Masdar City for at øge } \\
\text { nordiske eksportmuligheder. } \\
\text { En evaluering af Nordisk } \\
\text { Innovation blev sat i gang. } \\
\text { Der blev iværksat et tættere } \\
\text { samarbejde mellem institutionerne } \\
\text { i Oslo for at sikre synergier og øge } \\
\text { kvaliteten. }\end{array}$ \\
\hline
\end{tabular}

\section{$\underline{7-5180 \text { Nordisk Innovation }}$}

Institution
\begin{tabular}{|l|c|c|c|c|c|} 
Valuta & Budget 2016 & Budget 2015 & Budget 2014 & NMR fin. 14 & Budget disp. af \\
\hline NOK & 80.523 .000 & 80.523 .000 & 80.710 .000 & $69 \%$ & Institutionen \\
\hline Modsv. DKK & 72.471 .000 & 72.471 .000 & 79.096 .000 & &
\end{tabular}

I tillæg til den årlige bevilling gives en tilsagnsfuldmagt på 70 MNOK. Denne fordeles med maksimalt 40 MNOK 2017, 20 MNOK i 2018 og 10 MNOK i 2019.

Nordisk Innovations (NI) styre får dispositionsret til at gennemføre fagmæssige initiativer i NI. Beløbets størrelse fastsættes i en særkilt beslutning af MR-NER / EK-N.

Nordisk Innovation er forvaltningsorgan for en del af budgetpost 1-1012, Norden i Fokus.

Formål Nordisk Innovation (NI) har till syfte att bidra till ett hållbart, entreprenöriellt och innovativt näringsliv i Norden. Institutionen skall arbete för att utveckla och stärka det nordiska näringslivet som ett av de främsta och mest konkurrenskraftiga i världen. Nordisk Innovation skall på en faktabaserad grund skapa nätverk och samarbetsplattformar mellan nordiska offentliga och privata aktörer samt säkerställa nordiskt mervärde och synlighet.

I överensstämmelse med det av MR-NER beslutade samarbetsprogrammet för näringsområdet är följande mål fastlagda för 2016.

Kontraktperiode 2015

og status $\quad$ Nytt kontrakt 1. januari 2016 


\begin{tabular}{|c|c|c|}
\hline \multicolumn{3}{|l|}{ Mål og resultatopfølgning } \\
\hline 2016 - Mål & 2015 - Mål & 2014 - Opnåede resultater \\
\hline $\begin{array}{l}\text { NI skal medvirke til, at Norden } \\
\text { udvikles til en foregangsregion } \\
\text { inden for: innovative digitale } \\
\text { løsninger, innovative } \\
\text { velfcrdsløsninger, grøn vcekst, } \\
\text { kulturelle og kreative industrier, } \\
\text { og entreprenørskab og } \\
\text { finansiering. Det skal bl.a. ske } \\
\text { ved, at fyrtårnsprojekterne i } \\
\text { samarbejdsprogrammet } \\
\text { gennemføres og bliver } \\
\text { betydningsfulde nordiske } \\
\text { satsninger i et bredt forankret } \\
\text { samarbejde med relevante } \\
\text { myndigheder og interessenter. } \\
\text { NI skal forslå et konkret } \\
\text { fællesnordisk indsatsområde, som } \\
\text { MR-N bør fokusere på de næste } \\
\text { år, og som NI skal arbejde med i } \\
\text { årene fremover. } \\
\text { Finske formandskabsinitiativer } \\
\text { inden for erhvervssektoren skal } \\
\text { være igangsat med bistand fra NI. } \\
\text { Øget innovation, styrket } \\
\text { konkurrenceevne og } \\
\text { bæredygtighed i nordiske } \\
\text { virksomheder gennem projekter } \\
\text { med tydelig fællesnordisk } \\
\text { merværdi. } \\
\text { Øget internationalisering af } \\
\text { nordiske innovative } \\
\text { virksomheder gennem } \\
\text { fællesnordiske initiativer. } \\
\text { NI’s virksomhed og arbejde skal, } \\
\text { med udgangspunkt i resultaterne } \\
\text { og anbefalingerne fra } \\
\text { evalueringsrapporten, være mere } \\
\text { strategiske og effektive end } \\
\text { tidligere. }\end{array}$ & $\begin{array}{l}\text { NI kommer til å fortsette arbeidet } \\
\text { med de } 5 \text { prioriterte } \\
\text { fyrtårnprosjektene som ble satt i } \\
\text { gang i 2014, og programmene } \\
\text { blir lansert med de eksisterende } \\
\text { finansieringsverktøyene som NI } \\
\text { har til rådighet. NI skal proaktivt } \\
\text { skape og støtte under nettverk } \\
\text { programmer i samarbeid med } \\
\text { relevante myndigheter. } \\
\text { NI kommer til å finansiere flere } \\
\text { eksterne prosjekter under } 2015 \\
\text { under bl.a.: } \\
\text { Nordic Solved, Marine } \\
\text { Innovation, Bioøkonomi, } \\
\text { Innovative nordiske, } \\
\text { velferdsløsninger, Nordic Mining } \\
\text { og Nordic Built Cities. Disse skal } \\
\text { settes i gang og følges opp i } \\
\text { begynnelsen av 2015. } \\
\text { NI skal også understøtte relevante } \\
\text { danske formandskabinitiativer. } \\
\text { NI vil prioritere at bidrage til et } \\
\text { øget og effektivt administrativt } \\
\text { samarbeide mellom de nordiske } \\
\text { institusjonene i Oslo. }\end{array}$ & $\begin{array}{l}\text { Støtte til igangsættelsen af det } \\
\text { nye Nordiske erhvervs-og } \\
\text { innovationspolitiske } \\
\text { samarbejdsprogram udformning } \\
\text { og videreførelse af arbejdet med } \\
\text { de } 5 \text { fyrtårnsprojekter som er lagt } \\
\text { frem i samarbejdsprogrammet. } \\
\text { Disse fem programmer er: } \\
\text { Nordic Built Cities, Nordisk } \\
\text { partnerskap for entreprenørskap } \\
\text { og finansering, Innovative } \\
\text { nordiske digitale løsninger, } \\
\text { Innovative nordiske } \\
\text { velferdsløsninger, Nordisk } \\
\text { partnerskap for ekspansjon av } \\
\text { kulturelle og kreative næringer. } \\
\text { Endvidere fortsatte NI arbejdet på } \\
\text { andre indsatsområder, bl.a. } \\
\text { Innovation i mineindustrien, } \\
\text { Bioøkonomi og Marine } \\
\text { innovation. } \\
\text { I } 2014 \text { fortsatte NI også Nordic } \\
\text { Solved løsningen, hvilket er en } \\
\text { åben og ikke-sektor specifik } \\
\text { finansieringsmulighed til } \\
\text { nordiske projekter hvor høj } \\
\text { innovationsværdi og nordisk } \\
\text { nytte er i centrum. }\end{array}$ \\
\hline
\end{tabular}




\section{$\underline{7-5280 \text { Nopef }}$}

Programlignende aktiviteter
\begin{tabular}{|l|c|c|c|c|c|} 
Valuta & Budget 2016 & Budget 2015 & Budget 2014 & Disp./bud. 14 & Budget disp. af \\
\hline DKK & 15.162 .000 & 15.162 .000 & 14.938 .000 & $100 \%$ & EK-NER/Energi
\end{tabular}

Formål Nopef har till föremål för sin verksamhet att stärka nordiska små och medelstora företags (SME) internationella konkurrenskraft genom riskavlyft i form av stöd till förstudier och förberedande aktiviteter inför affärsetableringar och investeringar utanför EU/Efta-området. Nopef administreras som Trust Fund av Nordiska Miljöfinansieringsbolaget (NEFCO) och är inriktat på projekt relaterade till miljö, klimat och grön tillväxt.

\section{Forvaltnings- NEFCO organ}

\begin{tabular}{|c|c|c|}
\hline \multicolumn{3}{|l|}{ Mål og resultatopfølgning } \\
\hline 2016 - Mål & 2015 - Mål & 2014 - Opnåede resultater \\
\hline $\begin{array}{l}\text { Nopef ska bidra till positiva } \\
\text { miljöeffekten i projektländerna } \\
\text { genom att stötta aktiviteter inom } \\
\text { miljö, klimat och grön tillväxt. } \\
\text { Nopef ska också bidra till ögat } \\
\text { sysselsetting och ekonomisk } \\
\text { tillväkst i verksamheterna som } \\
\text { stöttas. } \\
\text { Minst } 60 \text { nya SME-företag ska } \\
\text { beviljas stöd för förstudier inför } \\
\text { internationalisering. Som ett } \\
\text { resultat av förstudierna ska } 50 \text { \% } \\
\text { av dessa ha medfört export. } \\
\text { Under } 2016 \text { ska Nopef utvärdera } \\
\text { resultat, nytta och ekonomiska } \\
\text { effekter från etableringar som } \\
\text { realiserats med bidrag från Nopef } \\
\text { under } 2013\end{array}$ & $\begin{array}{l}\text { Inom ramarna för tillgängliga } \\
\text { budgetmedel och återförda } \\
\text { projektmedel är målet att bevilja } \\
\text { finansiering till } 60 \text { kvalificerade } \\
\text { förstudieprojekt och att uppnå en } \\
\text { realiseringsgrad på } 40 \text { \% (d.v.s. } \\
\text { genomförd etablering) för } \\
\text { avslutade projekt. } \\
\text { Verksamheten strävar till ett } \\
\text { aktivt samarbete och } \\
\text { informationsutbyte med både } \\
\text { nationella och nordiska } \\
\text { näringsfrämjande organisationer. } \\
\text { Fonden stöder projekt där } \\
\text { nordiskt intresse föreligger } \\
\text { genom bl.a. ökad sysselsättning } \\
\text { och konkurrenskraft inom SME- } \\
\text { sektorn, främjandet av nordisk }\end{array}$ & $\begin{array}{l}\text { Sammanläggningen av Nopef och } \\
\text { NEFCO trädde i kraft den } \\
\text { 1.1.2014. Genom } \\
\text { sammanläggningen har Nopef } \\
\text { upphört att verka som en } \\
\text { självständig nordisk institution } \\
\text { och versamheten har övergått till } \\
\text { en Trust Fund (Nopef TF) } \\
\text { förvaltad av NEFCO med syftet } \\
\text { att främja internationalisering av } \\
\text { nordiska SME-företag, med en } \\
\text { förnyad inriktning på projekt } \\
\text { relaterade till miljö, klimat och } \\
\text { grön tillväxt. Nopef beviljade } 66 \\
\text { nya villkorslån under } 2014 \text { till ett } \\
\text { värde av totalt 2,1 mn EUR, och } \\
\text { genomförde } 34 \\
\text { utlandsetableringar och } \\
\text { investeringar, fördelat på } 15 \text { olika } \\
\text { projektländer. Realiseringsgraden } \\
\text { för avslutade lån under året steg } \\
\text { därmed till } 57 \text { \%. }\end{array}$ \\
\hline
\end{tabular}




\section{Energi}

\section{7-5141 Projektmedel - Energi}

Projektmidler
\begin{tabular}{|l|c|c|c|c|c|} 
Valuta & Budget 2016 & Budget 2015 & Budget 2014 & Disp./bud. 14 & Budget disp. af \\
\hline DKK & 4.130 .000 & 4.130 .000 & 4.192 .000 & $96 \%$ & EK-E
\end{tabular}

Formål

Projektmidlerne skal blandt andet bidrage til gennemførelsen af de nordiske energiministres handlingsprogram for energisamarbejdet. Dette skal bidrage til stabil forsyningssikkerhed, bæredygtig udvikling og velfærd for borgerne samt fremme af klima- og miljøvenlige løsninger, herunder skabelsen af forudsætninger for grøn vækst. Samarbejdet skal også bidrage til markedsføring af de nordiske styrkepositioner på energiområdet samt til de nordiske landes indflydelse på og implementering af EU-lovgivning.

I overensstemmelse med det af MR-NER besluttede samarbejdsprogram for energisektoren 2014 - 2017 er nedenstående mål fastlagt for 2016. Målene søges realiseret gennem de tre arbejdsgrupper på områderne energieffektivisering, vedvarende energi og elmarkedet, samt gennem projektaktivitet på områderne transport, branding og grøn vækst.

\begin{tabular}{|c|c|c|}
\hline \multicolumn{3}{|l|}{ Mål og resultatopfølgning } \\
\hline 2016 - Mål & 2015 - Mål & 2014 - Opnåede resultater \\
\hline $\begin{array}{l}\text { De overordnede målsætninger for } \\
\text { projektmidlernes anvendelse } \\
\text { knytter sig til mandatet for de tre } \\
\text { arbejdsgrupper, der gælder for } \\
\text { perioden 2016-2017. På baggrund } \\
\text { af beslutning i } 2015 \text { vil der evt. } \\
\text { blive gennemført en strategisk } \\
\text { gennemlysning af sektoren. Der } \\
\text { vil under året blive afholdt en } \\
\text { formandskabskonference, temaet } \\
\text { er endnu ikke fastlagt. }\end{array}$ & $\begin{array}{l}\text { Der skal udarbejdes nye mandater } \\
\text { til sektorens arbejdsgrupper } \\
\text { indenfor vedvarende energi, } \\
\text { energieffektivisering og } \\
\text { elmarkedet til opfyldelse af } \\
\text { sektorens handlingsprogram. } \\
\text { Herudover afholdes en højniveau } \\
\text { konference om det nordiske } \\
\text { elmarked med fokus på } \\
\text { udfordringer og muligheder for } \\
\text { Norden i den europæiske } \\
\text { kontekst, samt en konference om } \\
\text { kommunal og regional } \\
\text { energiplanlægning. Projektet } \\
\text { Nordsyn skal afsluttes og } \\
\text { afrapporteres til MR-NER. } \\
\text { Sektoren arbejder for en } \\
\text { strategisk gennemlysning i } 2016 .\end{array}$ & $\begin{array}{l}\text { Energisektorens projektmidler } \\
\text { har hovedsagligt bidraget til } \\
\text { arbejdet med de prioriterede } \\
\text { områder } \\
\text { som er energieffektivisering, } \\
\text { elmarkedet og vedvarende energi, } \\
\text { der hver især har været dækket af } \\
\text { en arbejdsgruppe. Samarbejdet } \\
\text { har blandt andet opnået resultater } \\
\text { gennem en øget integrering af det } \\
\text { fællesnordiske elmarked, } \\
\text { samarbejde omkring } \\
\text { implementering af EU-direktiver } \\
\text { inden for energieffektivisering } \\
\text { samt indspil til EU's energi- og } \\
\text { klimaramme } 2030\end{array}$ \\
\hline
\end{tabular}




\section{7-3220 Nordisk Energiforskning (NEF)}

Institution
\begin{tabular}{|l|c|c|c|c|c|} 
Valuta & Budget 2016 & Budget 2015 & Budget 2014 & NMR fin. 14 & Budget disp. af \\
\hline NOK & 7.169 .000 & 7.169 .000 & 7.113 .000 & $33 \%$ & Institutionen \\
\hline Modsv. DKK & 6.452 .000 & 6.452 .000 & 6.971 .000 & &
\end{tabular}

Nordisk Energiforskning styre får dispositionsret til at gennemføre fagmæssige initiativer i NEF. Beløbets størrelse fastsættes i en særkilt beslutning af MR-NER / EK-E.

Nordisk Energiforskning er sekretariat for Elmarkedsgruppen og Arbejdsgruppen for fornybar energi under EK-E (budgetpost 7-5141).

Formål Nordisk Energiforskning (NEF) har til formål at finansiere og fremme nordisk samarbejde om energiforskning samt give et forskningsbaseret grundlag for de energipolitiske beslutninger. NEFs opgaver varetages bl.a. ved at koble FoU til relevante energipolitiske processer, og ved at fungere som brobygger mellem industri, forskning og policy aktører. Videre skal NEF være aktør i det internationale energiforskningssamarbejde blandt andet i forhold til det europæiske forskningsrum (ERA) og International Energy Agency (IEA).

Kontraktperiode Ny kontrakt 1. januar 2015 og status

\begin{tabular}{|c|c|c|}
\hline \multicolumn{3}{|l|}{ Mål og resultatopfølgning } \\
\hline 2016 - Mål & 2015 - Mål & 2014 - Opnåede resultater \\
\hline $\begin{array}{l}\text { Opfølgning på gennemførelsen } \\
\text { NEFs nye flagskibsprojekter } \\
\text { lanceret i } 2015 . \\
\text { NEF vil medvirke aktivt til } \\
\text { gennemførelsen af Nordisk } \\
\text { Senters fælles forsknings- og } \\
\text { innovationsprogram Green } \\
\text { Growth. } \\
\text { NEF vil styrke sit bidrag til forsk- } \\
\text { ningsbaseret grundlag for poli- } \\
\text { tikudvikling gennem lansering af } \\
\text { Nordic Energy Technology } \\
\text { Perspectives 2016. } \\
\text { Fortsat styrkelse af NEFs } \\
\text { engagement som sekretariat for } \\
\text { arbejdsgrupperne for el-markedet } \\
\text { og vedvarende energi samt evt. } \\
\text { andre arbejdsgrupper. } \\
\text { Påtage sig støttefunktioner for } \\
\text { den planlagde strategiske } \\
\text { gennemlysning af det nordiske } \\
\text { samarbejde på energiområdet. } \\
\text { Styrkelse af NEFs deltagelse i } \\
\text { internationalt energisamarbejde. }\end{array}$ & $\begin{array}{l}\text { Lancering af NEFs nye strategi- } \\
\text { ske forskningsprogram og finan- } \\
\text { siering af energiforsknings- } \\
\text { prosjekter i Norden med identi- } \\
\text { fikation af flagskibsprosjekter. } \\
\text { Prioritering og bidrag til øget og } \\
\text { effektivt administrativt } \\
\text { samarbejde mellem de nordiske } \\
\text { institutioner i Oslo. } \\
\text { Muligheden for at øge sit bidrag } \\
\text { til forskningsbaseret grundlag for } \\
\text { politikudvikling gennem } \\
\text { lansering af Nordic Energy } \\
\text { Technology Perspectives } 2016 \\
\text { undersøges. } \\
\text { Udarbejdelse af nye vedtægter for } \\
\text { institutionen. }\end{array}$ & $\begin{array}{l}\text { Vedtagelse af ny 4-årig strategi. } \\
\text { Sekretariatsmæssig støtte til } \\
\text { Embedsmandskomiteens } \\
\text { arbejdsgrupper. } \\
\text { Afslutning af NEF's deltagelse i } \\
\text { TFI-programmet samt } \\
\text { planlægning af samarbejdet i det } \\
\text { kommende Green Growth } \\
\text { program i Nordisk Senter. } \\
\text { Arbejde med gennemførelse af } \\
\text { moderniseringsreformen i NEF } \\
\text { og Nordisk Senter som helhed. } \\
\text { NEF har stået for udlysninger af } \\
\text { projekter under ERA-Net Smart } \\
\text { Grids Plus. Dette placerer NEF } \\
\text { centralt i europæisk } \\
\text { forskningssamarbejde, og } \\
\text { bidrager til } \\
\text { kompetenceudbygning inden for } \\
\text { NEF’s kerneopgaver. }\end{array}$ \\
\hline
\end{tabular}




\section{Regional}

$\underline{\text { 7-5143 Implementering av samarbetsprogram, demografi, arbetsgrupper och projektmedel }}$

Projektmidler
\begin{tabular}{|l|c|c|c|c|c|} 
Valuta & Budget 2016 & Budget 2015 & Budget 2014 & Disp./bud. 14 & Budget disp. af \\
\hline DKK & 5.320 .000 & 5.320 .000 & 5.393 .000 & $90 \%$ & EK-R
\end{tabular}

Formål

Att genomföra det nordiska regionalpolitiska samarbetsprogrammet för perioden 2013 2016. Programmet ska 1) Bidra till en regionalt hållbar välfärdsutveckling, 2) Främja en hållbar regional utveckling i Arktis, samt 3) Stimulera en grön tillväxt i alla regioner.

Arbetet genomförs i fyra arbetsgrupper under ÄK-R inom 1) Välfärd/demografi, 2) Arktis, 3) Grön tillväxt - innovation, 4) Grön tillväxt - plansamarbete och hållbara stadsregioner.

I överensstämmelse med det av MR-NER beslutade samarbetsprogrammet för regionalsektorn 2013 - 2016 är följande mål fastlagda för 2016.

\begin{tabular}{|c|c|c|}
\hline \multicolumn{3}{|l|}{ Mål og resul } \\
\hline 2016 - Mål & Mål & \\
\hline $\begin{array}{l}\text { Att slutföra arbetet i de fyra } \\
\text { arbetsgrupperna som en del i } \\
\text { genomförandet av det nordiska } \\
\text { regionalpolitiska } \\
\text { samarbetsprogrammet 2013- } \\
\text { 2016: } \\
\text { Bidra till en regionalt hållbar } \\
\text { välfärds- och } \\
\text { demografiutveckling, } \\
\text { Främja en hållbar regional } \\
\text { utveckling i Arktis, } \\
\text { Stimulera en grön tillväxt i alla } \\
\text { regioner genom hållbart } \\
\text { utnyttjande av naturresurser, } \\
\text { Visa hur fysisk planering kan } \\
\text { bidra till grön tillväxt i Nordens } \\
\text { storstadsregioner. } \\
\text { Att genomföra en omfattande } \\
\text { förmedlingsinsats för att sprida } \\
\text { resultaten av arbetsgruppernas } \\
\text { insats till yrkesfolk på statlig, } \\
\text { regional och kommunal nivå i } \\
\text { hela Norden. }\end{array}$ & $\begin{array}{l}\text { välfärd skall under } 2015 \text { lansera } \\
\text { Nordmap - ett nytt interaktivt } \\
\text { web-baserat kartverktyg, } \\
\text { presentera översikt över vilka } \\
\text { nationella politiker och strategier } \\
\text { som finns inom } \\
\text { demografiområdet, igångsätta ett } \\
\text { nytt projekt om social innovation } \\
\text { samt samla upp på resultaten från } \\
\text { demografiprogrammet. } \\
\text { Arbetsgruppen för hållbar } \\
\text { utveckling i Arktis skall } \\
\text { genomföra andra och tredje } \\
\text { faserna i Foresight-analysen, de } \\
\text { så kallade realiserings- och } \\
\text { genomförandefaserna på regional } \\
\text { och nationell nivå samt } \\
\text { genomföra studier av } \\
\text { näringslivets utveckling och de } \\
\text { politiska och planeringsmässiga } \\
\text { ramarna för utvecklingen i } \\
\text { Arktis. } \\
\text { Arbetsgruppen för grön tillväxt: } \\
\text { innovation och entreprenörskap } \\
\text { skall supplera den nordiska } \\
\text { översikten med regional analys, } \\
\text { genomföra ytterligare två } \\
\text { fördjupningsstudier - varav en } \\
\text { om industriell symbios och en om }\end{array}$ & $\begin{array}{l}\text { välfärd har sjösatt ett nytt } \\
\text { demografiprogram, utarbetat ett } \\
\text { komplement till den så kallade } \\
\text { demografihandboken i form av en } \\
\text { exempelsamling med intressanta } \\
\text { projekt och strategier för att } \\
\text { tackla demografiska utmaningar } \\
\text { på regional och lokal nivå samt } \\
\text { igångsatt initiativ för att utveckla } \\
\text { ett interaktivt web-baserat } \\
\text { kartverktyg. } \\
\text { Arbetsgruppen för hållbar } \\
\text { regional utveckling i Arktis har } \\
\text { genomfört den första fasen av en } \\
\text { Foresight-analys - visionsfasen - } \\
\text { i tolv lokalsamfund i Norge, } \\
\text { Sverige, Finland, Island, } \\
\text { Grönland och Färöarna, utarbetat } \\
\text { ett omfattande bakgrundsmaterial } \\
\text { i form av rapporter om } \\
\text { demografi, ekonomisk utveckling } \\
\text { och näringsliv i Arktis samt } \\
\text { genomfört ett seminarium om } \\
\text { storskala-projekt. } \\
\text { Arbetsgruppen för grön tillväxt: } \\
\text { innovation och entreprenörskap } \\
\text { har utarbetat en översikt över } \\
\text { existerande studier, analyser och } \\
\text { program angående grön tillväxt i } \\
\text { Norden, genomfört en fördjupad }\end{array}$ \\
\hline
\end{tabular}




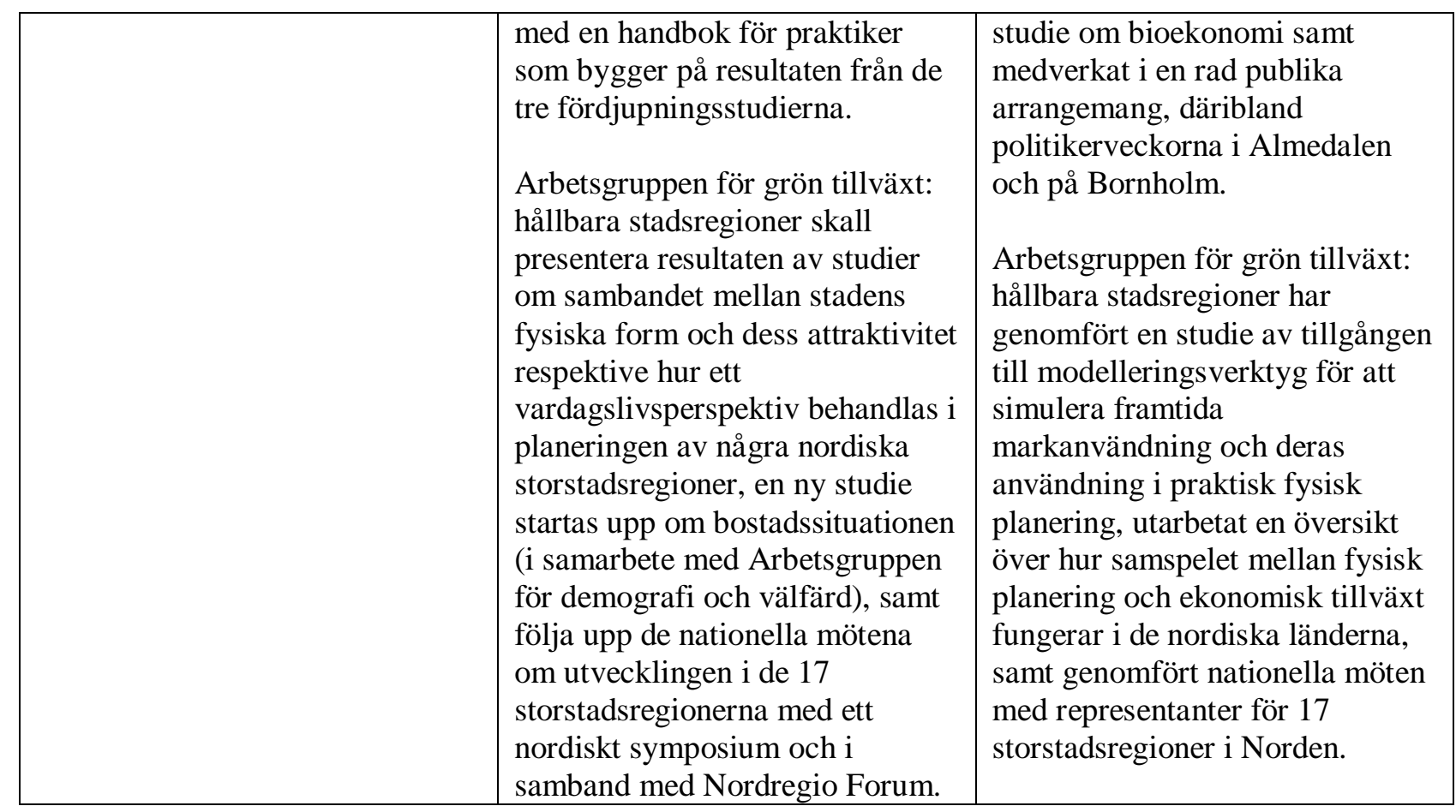

\section{$\underline{7-5151 \text { NORA }}$}

Organisationsbidrag
\begin{tabular}{|l|c|c|c|c|c|} 
Valuta & Budget 2016 & Budget 2015 & Budget 2014 & Disp./bud. 14 & Budget disp. af \\
\hline DKK & 6.624 .000 & 6.624 .000 & 6.640 .000 & $100 \%$ & EK-R
\end{tabular}

Formål NORA skall stärka och utveckla samarbetet i den nordatlantiska regionen (Grönland, Island, Färöarna och Kust-Norge) samt med nordens grannar i väst (Kanada, Skottland och Irland). NORA bidra till att göra nordatlanten till en kraftfull nordisk region med en stark och hållbar ekonomisk utveckling. NORA skall fungera som en strategisk aktör och pådrivare i de nordatlantiska ländernas projektsamarbete.

Forvaltnings- NORA - Nordiskt atlantsamarbete organ

\begin{tabular}{|c|c|c|}
\hline \multicolumn{3}{|l|}{ Mål- och resultatuppföljning } \\
\hline 2016 - Mål & 2015 - Mål & 2014 - Opnåede resultater \\
\hline $\begin{array}{l}\text { Genomföra strategiprogrammet } \\
\text { för perioden } 2012 \text { - } 2016\end{array}$ & $\begin{array}{l}\text { Genomföra strategiprogrammet } \\
\text { för perioden } 2012 \text { - } 2016\end{array}$ & $\begin{array}{l}\text { Nordatlantisk Tankesmie } \\
\text { udarbejdede sin fjerde anbefaling } \\
\text { om CSR i en nordatlantisk }\end{array}$ \\
\hline $\begin{array}{l}\text { Stärka innovation och samarbete } \\
\text { inom fiskeri och marina resurser, }\end{array}$ & $\begin{array}{l}\text { Stärka innovation och samarbete } \\
\text { inom fiskeri och marina resurser, }\end{array}$ & kontekst. \\
\hline $\begin{array}{l}\text { Främja differentieringen av } \\
\text { regionens ekonomier för att skapa } \\
\text { nya möjligheter, }\end{array}$ & $\begin{array}{l}\text { Främja differentieringen av } \\
\text { regionens ekonomier för att skapa } \\
\text { nya möjligheter, }\end{array}$ & $\begin{array}{l}\text { NORA gennemførte sin første } \\
\text { online konference under } \\
\text { overskriften Digital Arctic. }\end{array}$ \\
\hline $\begin{array}{l}\text { Utveckla lösningar på } \\
\text { geografiska utmaningar i } \\
\text { regionen }\end{array}$ & $\begin{array}{l}\text { Utveckla lösningar på } \\
\text { geografiska utmaningar i } \\
\text { regionen }\end{array}$ & $\begin{array}{l}\text { NORA videreudviklede sin } \\
\text { projektportefølje med særligt } \\
\text { fokus på inddragelse af partnere } \\
\text { fra naboerne i vest. }\end{array}$ \\
\hline
\end{tabular}


NORA skall genom konkreta initiativ omsätta handlingsplanen för 2016 med fokus på att:

Utveckla en attraktiv plattform för nordiskt samarbete med grannländerna, särskilt grannarna i väst, Kanada, Skottland och Irland.

Bidra i realiseringen av det regionalpolitiska

samarbetsprogrammets mål om att stärka en hållbar näringslivsutveckling i Arktis.

Bidra i arbetet med att ta fram en utvecklingsstrategi för Västnorden.
I 2015 udmøntes de overordnede målsætninger i en handlingsplan med særligt fokus på følgende hovedpunkter:

Formulering af vestnordisk udviklingsstrategi.

Gennemførelse af NORA REGION CONFERENCE 2015 om internationale nichearrangementer som regionalt turismepotentiale.

Gennemførelse af konkrete samarbejdsprojekter med naboerne i vest.

Opfølgning på konferencen Digital Arctic.
NORA REGION TRENDS blev videreudviklet for at styrke portalens rolle som en væsentlig nyhedskilde om nye erhvervsudviklingsmuligheder $\mathrm{i}$ Nordatlanten og Arktis.

NORA bidrog til opstart af proces, som i 2015-16 skal munde ud i den første, konsoliderede udviklingsstrategi for Vestnorden.

Målen skall i huvudsak realiseras genom att skapa arenor för samarbete där gemensamma strategier och initiativ för nordatlantiska problemställningar kan utvecklas och konkreta projektsamarbeten i regionen kan initieras och förmedlas. NORA skall vara sekretariat för arbete under 2015 - 2016 med att ta fram en västnordisk utvecklingsstrategi.

7-5160 Gränsregionalt samarbete

Programlignende aktiviteter

\begin{tabular}{|l|c|c|c|c|c|} 
Valuta & Budget 2016 & Budget 2015 & Budget 2014 & Disp./bud. 14 & Budget disp. af \\
\hline DKK & 9.287 .000 & 9.287 .000 & 9.550 .000 & $88 \%$ & EK-R
\end{tabular}

Formål Gränskommittéerna skall bidra till att genomföra prioriteringarna för det gränsregionala samarbetet i det nordiska regionalpolitiska samarbetsprogrammet 2013 - 2016, Gränskommittéerna skall bidra till ett välfungerande och fruktbart gränsregionalt samarbete, samt att reducera gränshinder och att utveckla hållbara gränsregioner. Medlen fördelas för åren 2014 -2016 för att skapa bättre framförhållning och planeringsförutsättningar för gränskommittéerna. De nordiska medlen skall framförallt bidra till att upprätthålla den institutionella infrastrukturen i det gränsregionala samarbetet i Norden.

I överensstämmelse med det av MR-NER beslutade samarbetsprogrammet för regionalsektorn 2013 - 2016 är följande mål fastlagda för 2016.

\begin{tabular}{|l|l|l|}
\hline Mål og resultatopfølgning & 2015 - Mål & 2014 - Opnåede resultater \\
\hline 2016 - Mål & Gränskommittéerna skall inom & $\begin{array}{l}\text { En ny finansieringsmodell för } \\
\text { perioden 2014 - 2016 för } \\
\text { gränskommittéerna har tagits } \\
\text { fram. }\end{array}$ \\
\hline $\begin{array}{l}\text { Utvärdera gränskommittéerna för det gränsregionala } \\
\text { och dess finansiering. }\end{array}$ & samarbetet bidra till att: \\
$\begin{array}{l}\text { Ta fram en långsiktig } \\
\text { finansieringsmodell för }\end{array}$ & Samla lokala och regionala & \\
\hline
\end{tabular}




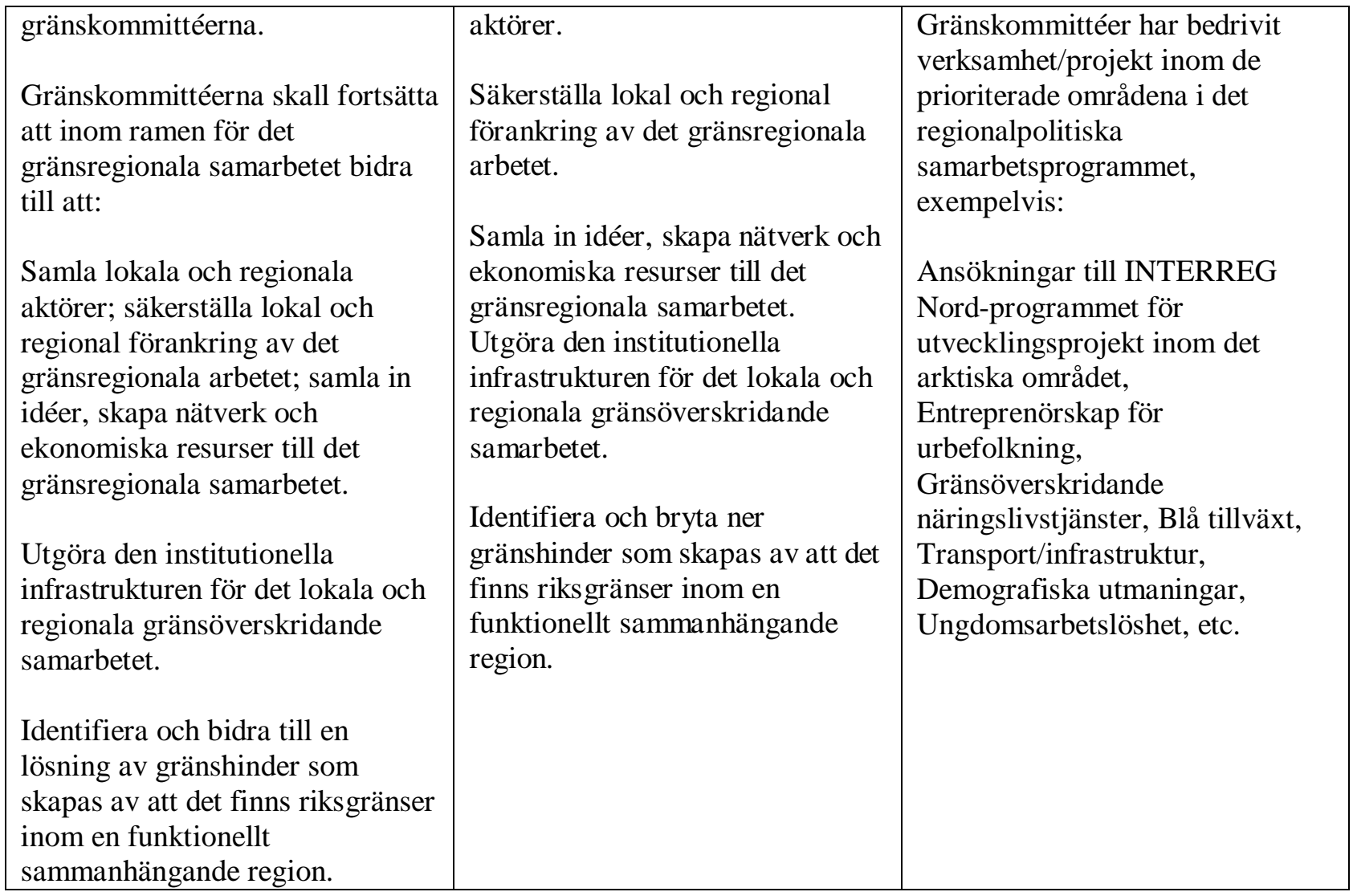

\section{7-6180 Nordregio}

Institution
\begin{tabular}{|l|c|c|c|c|c|} 
Valuta & Budget 2016 & Budget 2015 & Budget 2014 & NMR fin. 14 & Budget disp. af \\
\hline SEK & 13.559 .000 & 13.559 .000 & 13.449 .000 & $58 \%$ & Institutionen \\
\hline Modsv. DKK & 11.254 .000 & 11.254 .000 & 11.701 .000 & &
\end{tabular}

Nordregio er förvaltningsorgan för de fyra arbetsgrupper under ÄK-R (budgetpost 7-5143): Välfärd/demografi, Arktis, Grön tillväxt - innovation och Grön tillväxt - hållbara stadsregioner.

Formål Nordregio är en ledande nordisk forsknings institut inom regional utveckling och genomför strategisk forskning inom det regionalpolitiska området i syfte att ta fram underlag för beslutfattare på internationell, nationell och regional/lokal nivå.

Nordregio skall bidra till att genomföra och driva det nordiska regionalpolitiska samarbetet framåt, med sikte på att utveckla och stärka en hållbar utveckling i de nordiska regionerna. Nordregio skall genom sina riktade forskningsinsatser medverka till en hållbar tillväxt och ett mer konkurrenskraftigt, innovativt regionalt Norden.

I överensstämmelse med det av MR-NER beslutade samarbetsprogrammet för regionalsektorn 2013 - 2016 är följande mål fastlagda för 2016.

Kontraktperiode 2013-2016 og status 


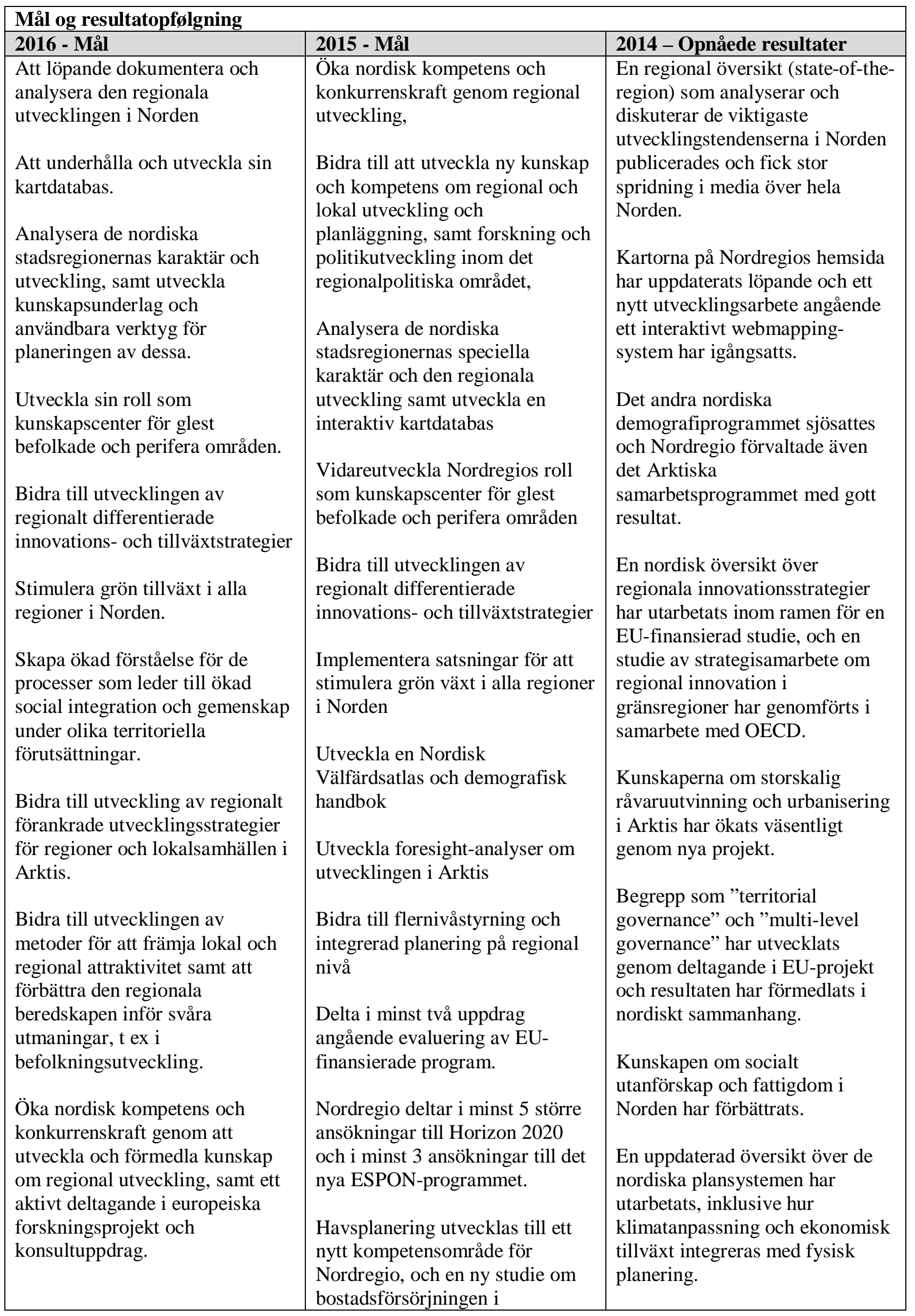




\begin{tabular}{|l|l|l|}
\hline & $\begin{array}{l}\text { storstäderna och glesbygden } \\
\text { inleds. }\end{array}$ & $\begin{array}{l}\text { Nordregio Forum genomfördes } \\
\text { för andra året i rad och blev } \\
\text { såväl program- som } \\
\text { deltagarmässigt en succé. }\end{array}$ \\
\hline
\end{tabular}




\section{Miljö}

\section{Generel indledning}

Formål og Det nordiske miljøsamarbejde skal bidrage til at bevare og forbedre miljøkvalitet og Fakta livskvalitet i Norden og påvirke internationale beslutninger.

De nordiske landes miljøsamarbejde udføres bl.a. gennem virksomheden i arbejdsgrupper og gennem Nordisk miljøudviklingsfonden (NMF) under Nordisk miljøfinanseringsselskab (NEFCO) og miljømærket Svanen. Internationalt prioriteres samarbejdet med EU og internationelle miljøkonventioner fx FN's miljøprogram (UNEP), Klimakonventionen (UNFCCC) og Biodiversitetskonventionen (CBD), samt med regionale organer, fx. Arktiskt Råd, Barentsrådet og Kommissionen for Østersøens miljøbeskyttelse (HELCOM).

Nordisk Ministerråds miljøsektor finansierer Nordisk Råds Miljöpris.

Strategiske målsætninger 2016
Miljøhandlingsprogrammet (MHP) dækker miljøsektorens arbejde for perioden 20132018. Hovedtemaerne i miljøhandlingsprogrammet er grøn samfundsudvikling, klimaforandringer og luftforurening, biologisk mangfoldighed og økosystemer, samt sundheds- og miljøskadelige kemikalier.

Programmet er sektorens vigtigste styringsdokument og udgangspunkt for miljøsamarbejdet. MHP indenholder udover ovenstående hovedtemaer blandt andet temaerne holdbar konsumption og produktion, ressourceeffektivitet og affald, kortlivede klimadrivere, planlægning på havet og havforsuring, friluftsliv, landskab og kulturmiljø.

De overordnede strategiske mål for miljøsektoren i 2016 er, at:

Deltage i og profilere Nordisk Ministerråds miljøsamarbejde regionalt og internationalt blandt andet i forhold til følgende områder: FN's klimaforhandlinger, EU's affaldspakke, FN's biodiversitetsarbejde i regi af CBD, cirkulær økonomi både i EU, OECD og FN og EU's kemikalielovgivning, samt relevante processer angående Arktis og Barentsregionen.

Undersøge og udvikle muligheder for nordisk bidrag til processer angående EU's luftpakke, de internationale kviksølv forhandlinger, FN's biodiversitetsforhandlinger (CBD) og HELCOM.

Arbejde for at styrke monitorering og beskyttelse af økosystemer og biodiversitet på land og i havet, ikke mindst i Arktis og Barentsregionen.

Fremme ressourceeffektivitet og cirkulær økonomi, arbejde for at sikre bæredygtig tekstil- og modebranche og affaldshåndtering i de nordlige og tyndt bebyggede områder.

I miljøsektoren er der ydermere planlagt en større strategisk tværgående satsning under prioriteringsbudgettet med henblik på en ambitiøs opfølgning på klimaforhandlingernes COP21 (Confe rence of Parties) i Paris december 2015. Det konkrete indhold afklares nærmere primo 2016 på baggrund af resultaterne fra COP21.

Forbedre tilstanden i havområderne, herunder i Østersøen, Nordøstatlanten og Arktis, bl.a. igennem arbejdet med økosystembaseret havmiljøforvaltning og indsatser mod marint affald og havforsurning. 
Arbejde for giftfri kredsløb i de nordiske lande med særlig fokus på hormonforstyrrende stoffer og kombinationseffekter (cocktaileffekter).

Ved behov følge op på den midtvejsevaluering af MHP, som er foretaget i løbet af 2015.

Ministerrådets resultater i 2014
Ministerrådets resultater fremkommer som et resultat af samspillet mellem politiske organer, finansiering af dagsaktuelle projekter fra dispositionsmidlerne, samt det konkrete projektarbejde i miljøsektorens otte arbejdsgrupper. De væsentligste resultater for sektoren i 2014 var:

Bæredygtig forbrug og produktion: Sektoren har bidraget med at videreudvikle et nordisk indspil til EU's ecodesigndirektiv bl.a. ved deltagelse i EU's Green Week. Derudover har man foretaget baggrundsstudier angående BAT (best available technique) om levnedsmidler og træbeskyttelse, som er indleveret til EU. Indenfor produktionssiden har man undersøgt forudsætningerne for at fremme en bæredygtig produktion af tekstiler i Tirupur, Indien, hvilket har spillet ind i det danske formandskabsprojekt om en fælles nordisk handlingsplan for bæredygtig mode og tekstil. På konsumentsiden er der udviklet skolematerialer om affaldsforebyggelse.

Affald: Sektoren har i årets løb arbejdet for, at miljøpåvirkninger fra håndtering af materialer i samfundet minimeres set fra et livscyklusperspektiv, og at forbruget af ressourcer frakobles økonomisk vækst gennem øget ressourceeffektivitet, forebyggelse og genanvendelse af affald. Sektoren har haft hovedansvaret for statsministernes Grøn vækst initiativer om affald. Her har fokus været på genbrug og genanvendelse af tekstil og plast med seks projekter og yderligere to nordiske workshops. Derudover har sektoren arbejdet yderligere med tekstil bl.a. med Life-Cycle Assessment.

Miljøøkonomi: Sektoren har i 2014 samlet viden om anvendelsen af økonomiske styremidler i miljøpolitikken med særlig fokus på miljøskadelige subsidier, værdisætning af miljø og økosystemtjenester og omkostningseffektiv udnyttelse og beskyttelse af naturressourcer.

Klima og luft: Sektoren har i 2014 udviklet nordisk input til klimaforhandlingerne, luftkonventionen (CLRTAP), EU, Arktisk Råd og Climate and Clean Air Coalition (CCAC) to reduce short-lived climate pollutants, startet arbejdet med NPI (Nordic Partnership Initiative on Up-Scaled Mitigation Action) med et pilotprojekt i Peru indenfor affald og et pilotprojekt i Vietnam indenfor cementsektoren, samt arbejdet med effekten af SLCP (shortlived climate pollutants) i Arktis. Bidragene har været i form af sammenfatning af vidensgrundlag, netværksdannelse, facilitering af processer og medfinansiering af projekter. Særlig fokus i 2014 indenfor det nordiske klimasamarbejde har været kommunikation af dels IPCC's 5. synteserapport gennem komik og interaktiv web om samme rettet mod unge i Norden, samt en massiv tilstedeværelse ved samtlige klimaforhandlingsmøder i løbet af året gennem en nordisk stand og uddeling af diverse baggrundsrapporter.

Biodiversitet og økosystemer: I løbet af 2014 har sektorens arbejde med biodiversitet haft fokus på metoder og værktøjer til beskyttelse af raske økosystemer og biodiversitet. Indspil til konventionen om biologisk mangfoldighed og EU's biodiversitetsstrategi er blevet udviklet og spillet ind, herunder indspil om restaurering af ødelagte økosystemer og initiativer om bekæmpelse af invasive arter. Derudover har sektoren arbejdet med økosystemtjenester i landskabet i form af oplevelser og koblingen mellem verdensarv og bæredygtig turisme.

Hav: Sektoren har i 2014 bl.a. arbejdet med opbygning af videnskabeligt baggrundsmateriale for fælles tiltag mod forurening af nordiske hav- og kystmiljøer. Og 
derudover har sektoren arbejdet særligt med marint affald, havforsuring og økosystembaseret forvaltning og kommet med konkret input om dette til samarbejdsorganer indenfor EU og de regionale havkonventioner, beskyttelse af det marine miljø i Nordøstatlanten (OSPAR) og Helsingforskonventionen om beskyttelse af Østersøen (HELCOM).

Kemikalier: Sektoren har i 2014 arbejdet målrettet mod at påvirke internationale processer bl.a. EU lovgivning og OECD forhandlinger. Det er gjort igennem udarbejdelsen af nordiske input i form af baggrundsmateriale til diskussionerne. Mere konkret har sektoren bidraget til EU's arbejde med testmetoder, bidraget til OECD's arbejde med nanomaterialer og indpil til Montreal-protokollen. Derudover har sektoren arbejdet med omkostningerne for de nordiske samfund ved hormonforstyrrende stoffer i rapporten "The Cost of Inaction".

\begin{tabular}{llrrrr} 
& & Budget & Budget & \multicolumn{2}{c}{ Difference } \\
& & $\mathbf{2 0 1 6}$ & $\mathbf{2 0 1 5}$ & \multicolumn{1}{c}{+ - } & $\mathbf{~ \% ~}$ \\
\hline MR-Miljø (TDKK) & $\mathbf{4 4 . 1 5 7}$ & $\mathbf{4 4 . 1 5 7}$ & $\mathbf{0}$ & $\mathbf{0 , 0 \%}$ \\
& & & & \\
$8-3310$ & Dispositionsmidler - Miljø & 4.241 & 5.732 & -1.491 & $-26,0 \%$ \\
$8-3311$ & Miljøsektorens arbejdsgrupper & 24.101 & 22.601 & 1.500 & $6,6 \%$ \\
$8-3312$ & Nordisk Råds miljøpris & 600 & 609 & -9 & - \\
$8-3320$ & NEFCOS Miljøudviklingsfond & 11.016 & 11.016 & 0 & $0,0 \%$ \\
$8-6720$ & SVANEN - Nordisk miljömärkning & 4.199 & 4.199 & 0 & $0,0 \%$ \\
& & & & & \\
\hline Opdelt på kategorier & $\mathbf{4 4 . 1 5 7}$ & $\mathbf{4 4 . 1 5 7}$ & $\mathbf{1 0 0 \%}$ & $\mathbf{1 0 0 \%}$ \\
\hline \multicolumn{2}{l}{ Projektmidler } & 4.241 & 5.732 & $9,6 \%$ & $13,0 \%$ \\
& Programlignende aktiviteter & 35.717 & 34.226 & $80,9 \%$ & $77,5 \%$ \\
$\quad$ Organisationsbidrag & 4.199 & 4.199 & $9,5 \%$ & $9,5 \%$
\end{tabular}

\section{$\underline{\text { 8-3310 Dispositionsmedel - Miljö }}$}

Projektmidler
\begin{tabular}{|l|c|c|c|c|c|} 
Valuta & Budget 2016 & Budget 2015 & Budget 2014 & Disp./bud. 14 & Budget disp. af \\
\hline DKK & 4.241 .000 & 5.732 .000 & 6.247 .000 & $97 \%$ & EK-M/MR-M
\end{tabular}

Formål Miljøsektorens prioriteringskonto anvendes løbende under budgetåret til politisk prioriterede og aktuelle projekter og initiativer. For ansøgninger fra arbejdsgrupperne gælder det derudover, at projekterne enten skal være politisk prioriterede, tværgående satsninger, som miljøsektoren ønsker at være en aktiv del af og/eller behandle en ny miljøfaglig udfordring, som ligger udover miljøhandlingsprogrammet.

\begin{tabular}{|c|c|c|}
\hline \multicolumn{3}{|l|}{ Mål og resultatopfølgning } \\
\hline 2016 - Mål & 2015 - Mål & 2014 - Opnåede resultater \\
\hline $\begin{array}{l}\text { At støtte aktuelle, politisk priori- } \\
\text { terede projekter indenfor Miljø- } \\
\text { handlingsprogrammet 2013-2018 } \\
\text { og særlige indsatsområder for } \\
\text { miliøsektorens virksomhed. }\end{array}$ & $\begin{array}{l}\text { At støtte aktuelle, politisk priori- } \\
\text { terede projekter indenfor Miljø- } \\
\text { handlingsprogrammet 2013-18 og } \\
\text { særlige indsatsområder for miljø- } \\
\text { sektorens virksomhed. }\end{array}$ & $\begin{array}{l}\text { I } 2014 \text { tildelte miljøsektoren } \\
\text { midler til } 23 \text { projekter fra } \\
\text { dispositionsmidler. Projekterne } \\
\text { omhandlede aktuelle } \\
\text { miliøpolitiske problemstillinger. }\end{array}$ \\
\hline
\end{tabular}


Særlig politiskt prioriterede temaer under år 2016 er bl.a. at støtte opfølgningen af COP21 i Paris, udvikling og styrket anvendelse af miljømærket Svanen, opfølgningen på midtvejsevalueringen af MHP, opfølgning på NEFCOs nye strategi, at arbejde for en giftfri hverdag, at fortsat samarbejde om bekæmpelse af invasive arter, implementering af Arctic Biodiversity Assessment, at arbejde videre med beskyttelse af vådområder, bl.a. som opfølgning på Ramsar konventionens arbejde med dette, opfølgning af

Aichimålene, samt løfte resultaterne fra det nordiske miljøsamarbejde særligt indenfor grøn vækst og luftforurening i regi af Economic Commission for Europe (UNECE).
Særlig politiskt prioriterade temaer under år 2015 er bl.a. støtte til EU's arbejde omkring affald og luftforurening, klimaforhandlingernes COP 21 (Conference of Parties) i Paris, relevante processer omkring CBD, herunder opfølgning af Aichimålene, havplanlægning, marint affald, havforsuring, beskyttelse af naturen i de arktiske områder og giftfri kredsløb.

\section{Udvalgte initiativer:}

Diverse projekter og initiativer indenfor udvikling af bæredygtig tekstil og mode. Input til EU's affaldskatalog og andre affaldsreducerende initiativer. Videre arbejde med udvikling af værktøjer og metoder til planlægning på havet (Marine Spatial Planning).

Udredningsarbejde til støtte for drivhusgasreducerende tiltag (mitigation). Støtte til regionale indsatser for beskyttelse af skove med særlig høj biodiversitet. Input til Intergovernmental Platform on Biodiversity and Ecosystem Services (IPBES) ved et nordisk studie. Et studie om cirkulær økonomi. Udredning af omkostningerne for de nordiske samfund ved hormonforstyrrende stoffer (The Cost of Inaction).

\section{8-3311 Miljøsektorens arbejdsgrupper}

\section{Programlignende aktiviteter}

\begin{tabular}{|l|c|c|c|c|c|} 
Valuta & Budget 2016 & Budget 2015 & Budget 2014 & Disp./bud. 14 & Budget disp. af \\
\hline DKK & 24.101 .000 & 22.601 .000 & 22.711 .000 & $98 \%$ & EK-M/MR-M
\end{tabular}

Formål Implementeringen af Miljøhandlingsprogrammet sker gennem sektorens otte arbejdsgrupper i form af såvel konkrete projekter som andre former for aktiviteter, herunder konferencer, analyser, videnskabelige og populære artikler, workshops og lignende. Både forberedelse, gennemførsel og opfølgning sker med deltagelse fra nordiske eksperter på det pågældende område.

Arbejdsgruppernes antal og tema er defineret ud fra MHP's opbygning. Det indebærer, at der under hovedtemaet "Grøn samfundsudvikling" er tre arbejdsgrupper: Affaldsgruppen (NAG), Holdbar konsumtion og produktion (HKP) og Miljø- og økonomigruppen (MEG); Under temaet "Klimaændringer og luftforurening” er to arbejdsgrupper: Klima og luftgruppen (KOL) og Den Nordiske arbejdsgruppe for globale klimaforhandlinger (NOAK); Under temaet "Biologisk mangfoldighed og økosystemer” er to arbejdsgrupper: Arbejdsgruppen for terrestriske økosystemer (TEG) og Marine økosystemer (HAV); Under temaet "Sundheds- og miljøskadelige kemikalier” er en arbejdsgruppe: Kemikaliegruppen (NKG).

Forvaltnings- $\quad$ Hver arbejdsgruppe har en fast koordinator, som er ansat i de nordiske landes miljøorgan myndigheder, som derved fungerer som forvaltningsorgan for den pågældende arbejdsgruppe.

\begin{tabular}{|l|l|l|}
\hline \multicolumn{2}{|l|}{ Mål og resultatopfølgning - Grøn samfundsudvikling } & \\
\hline 2016 - Mål & 2015 - Mål & 2014 - Opnåede resultater \\
\hline At arbejde mod øget & At arbejde mod øget resurseffek- & At give indspil til EU's \\
\hline
\end{tabular}




\begin{tabular}{|c|c|c|}
\hline $\begin{array}{l}\text { resurseffektivitet, bæredygtig } \\
\text { tekstil- og modebranche og } \\
\text { forebyggelse af affald. } \\
\text { At arbejde mod videre udvikling } \\
\text { og konkretisering af cirkulær } \\
\text { økonomi. } \\
\text { At arbejde med afklaring af } \\
\text { hvordan miljøsektoren bedst } \\
\text { muligt kan arbejde med } \\
\text { konsumentspørgsmålet. }\end{array}$ & $\begin{array}{l}\text { tivitet och forebyggelse af affald } \\
\text { især angå ende tekstilområdet og } \\
\text { udvikling af Svanemærket } \\
\text { At bidrage til bæredygtig affalds- } \\
\text { håndtering, især i nordlige og } \\
\text { tyndt bebyggede områder samt på } \\
\text { tekstil og plastområder (statsmi- } \\
\text { nisterinitiativet). }\end{array}$ & $\begin{array}{l}\text { ecodesigndirektiv bl.a. ved } \\
\text { deltagelse i EU's Green Week. } \\
\text { At udvikle baggrundsstudier } \\
\text { angående BAT (best available } \\
\text { technique) om levnedsmidler og } \\
\text { træbeskyttelse og indlevere dem } \\
\text { til EU. } \\
\text { At udvikle analyser, policy briefs, } \\
\text { videnskabelig viden og } \\
\text { baggrundsmaterialer om } \\
\text { genanvendelsen og genbrug af } \\
\text { tekstil og plastaffald. } \\
\text { At udarbejde viden om } \\
\text { anvendelsen af økonomiske } \\
\text { styremidler i miljøpolitikken } \\
\text { med særlig fokus på } \\
\text { miljøskadelige subsidier, } \\
\text { værdisætning af miljø og } \\
\text { økosystemtjenester og } \\
\text { omkostningseffektiv udnyttelse } \\
\text { og beskyttelse af naturressourcer. }\end{array}$ \\
\hline
\end{tabular}

\begin{tabular}{|c|c|c|}
\hline \multicolumn{3}{|c|}{ Mål og resultatopfølgning - Klimaændringer og luftforureninger } \\
\hline 2016 - Mål & 2015 - Mål & 2014 - Opnåede resultater \\
\hline $\begin{array}{l}\text { At støtte opfølgningen og } \\
\text { implementeringen af resultatet af } \\
\text { COP21, samt øvrige relevante } \\
\text { internationale processer, herunder } \\
\text { den videre udvikling og } \\
\text { implementering af EU’s luftpak- } \\
\text { ke, og løfte resultaterne fra det } \\
\text { nordiske miljøsamarbejde særligt } \\
\text { indenfor grøn vækst og } \\
\text { luftforurening på Eighth } \\
\text { Environment for Europe } \\
\text { Ministerial Conference. }\end{array}$ & $\begin{array}{l}\text { At støtte relevante internationale } \\
\text { processer, herunder udvikling og } \\
\text { implementering af EU’s luftpak- } \\
\text { ke, forhandlinger om kortlivede } \\
\text { klimadrivere (SLCP) og ikke } \\
\text { mindst klima-forhandlingerne } \\
\text { under FN, UNFCCC. Der vil især } \\
\text { være fokus på klimaforhandlin- } \\
\text { gerne idet en ny global klimaafta- } \\
\text { le skal besluttes på COP } 21 \text { i } \\
\text { Paris 2015. Indsatsen hér drejer } \\
\text { sig om formidling og kommuni- } \\
\text { kation af FN's klimapanels } \\
\text { (IPCC) rapporter, såvel som kon- } \\
\text { kret facilitering af forhandlings- } \\
\text { processer og brobygning mellem } \\
\text { de forskellige regionale fora i } \\
\text { form af afholdelse af tematiske } \\
\text { workshops og seminarer før og } \\
\text { under årets klimamøder. } \\
\text { Desuden vil sektoren i 2015, } \\
\text { såvel som i } 2014 \text { arbejde for at } \\
\text { fremme udslipsreduktioner og } \\
\text { dertil hørende rapporterings- } \\
\text { systemer, fremme forståelsen om } \\
\text { retfærdighed mellem landene i } \\
\text { klimaforhandlingerne og støtte en } \\
\text { effektiv implementering af klima- } \\
\text { finansiering og markedsme- } \\
\text { kansimer. }\end{array}$ & $\begin{array}{l}\text { At intensivere og nuancere } \\
\text { kommunikationsindsatsen af } \\
\text { klimaviden, herunder formidling } \\
\text { af IPCC's 5. synteserapport } \\
\text { gennem komik og interaktivt } \\
\text { rettet mod unge i Norden, samt } \\
\text { en massiv tilstedeværelse ved } \\
\text { samtlige klimaforhandlingsmøder } \\
\text { i løbet af året gennem en nordisk } \\
\text { stand og uddeling af diverse } \\
\text { baggrundsrapporter. } \\
\text { At udvikle nordisk input til } \\
\text { klimaforhandlingerne, } \\
\text { luftkonventionen (CLRTAP), } \\
\text { EU, Arktisk Råd og Climate and } \\
\text { Clean Air Coalition (CCAC) to } \\
\text { reduce short-lived climate } \\
\text { pollutants. } \\
\text { At have fået startet arbejdet med } \\
\text { NPI (Nordic Partnership } \\
\text { Initiative on Up-Scaled } \\
\text { Mitigation Action) med et } \\
\text { pilotprojekt i Peru indenfor affald } \\
\text { og et pilotprojekt i Vietnam } \\
\text { indenfor cementsektoren. }\end{array}$ \\
\hline
\end{tabular}




\begin{tabular}{|c|c|c|}
\hline \multicolumn{3}{|c|}{ Mål og resultatopfølgning - Biologisk mangfoldighed } \\
\hline 2016 - Mål & 2015 - Mål & 2014 - Opnåede resultater \\
\hline $\begin{array}{l}\text { At støtte internationale processer } \\
\text { indenfor biodiversitets- } \\
\text { konventionen med fokus på op- } \\
\text { følgelse af Aichi-målene om re- } \\
\text { staurering af natur, arbejde videre } \\
\text { med beskyttelse af vådområder, } \\
\text { bl.a. som opfølgning på Ramsar } \\
\text { konventionens arbejde med dette, } \\
\text { biodiversitetsevaluering og } \\
\text { monitorering, havkonventionerne } \\
\text { HELCOM og OSPAR om } \\
\text { økosystembaseret } \\
\text { havmiljøforvaltning, marint } \\
\text { affald, samt arbejdet med } \\
\text { naturbeskyttelse i Arktis, } \\
\text { herunder opfølgningen af ABA } \\
\text { rapporten og blandt andet } \\
\text { gennem støtte til Arktisk Råd og } \\
\text { Barentsrådets forskellige } \\
\text { initiativer. }\end{array}$ & $\begin{array}{l}\text { At støtte internationale processer } \\
\text { indenfor biodiversitets- } \\
\text { konventionen med fokus på op- } \\
\text { følgelse af Aichi-målene om re- } \\
\text { staurering af natur, biodiversi- } \\
\text { tetsevaluering og monitorering, } \\
\text { havkonventionerne HELCOM og } \\
\text { OSPAR om økosystembaseret } \\
\text { havmiljø-forvaltning, marint } \\
\text { affald inkl. plastik og farlige ke- } \\
\text { mikalier, havforsuring, samt ar- } \\
\text { bejdet med naturbeskyttelse i } \\
\text { Arktis blandt andet gennem støtte } \\
\text { til Arktisk Råd og Barentsrådets } \\
\text { forskellige initiativer. }\end{array}$ & $\begin{array}{l}\text { At videreudvikle metoder og } \\
\text { værktøjer til beskyttelse af sunde } \\
\text { økosystemer og biodiversitet } \\
\text { gennem indspil til konventionen } \\
\text { om biologisk mangfoldighed og } \\
\text { EU's biodiversitetsstrategi om } \\
\text { restaurering af ødelagte } \\
\text { økosystemer, initiativer om } \\
\text { bekæmpelse af invasive arter, } \\
\text { økosystemtjenester i landskabet } \\
\text { og koblingen mellem verdensarv } \\
\text { og bæredygtig turisme. } \\
\text { At have opbygget videnskabeligt } \\
\text { baggrundsmateriale for fælles } \\
\text { tiltag mod forurening af nordiske } \\
\text { hav- og kystmiljøer, og } \\
\text { derudover have arbejdet med } \\
\text { marint affald, havforsuring og } \\
\text { økosystembaseret forvaltning } \\
\text { rettet særligt mod } \\
\text { havkonventionerne om } \\
\text { beskyttelse af det marine miljø i } \\
\text { Nordøstatlanten (OSPAR) og } \\
\text { Helsingforskonventionen om } \\
\text { beskyttelse af Østersøen } \\
\text { (HELCOM). }\end{array}$ \\
\hline
\end{tabular}

\begin{tabular}{|l|l|l|}
\hline \multicolumn{2}{|l|}{ Mål og resultatopfølgning - Helse og miljøfarlige kemikalier } \\
\hline 2016 - Mål & 2015 - Mål & 2014 - Opnåede resultater \\
\hline $\begin{array}{l}\text { At fremme giftfrit kredsløb via } \\
\text { arbejde med kemikalieregulering, } \\
\text { kviksølv og hormonforstyrrende } \\
\text { emner, samt kemikalier i produk- } \\
\text { ter. }\end{array}$ & $\begin{array}{l}\text { At fremme giftfri kredsløb via } \\
\text { arbejde med kemikalieregulering, } \\
\text { kviksølv og hormonforstyrrende } \\
\text { emner, samt kemikalier i produk- } \\
\text { ter. }\end{array}$ & $\begin{array}{l}\text { At bidrage til EU's arbejde med } \\
\text { testmetoder og OECDs Test } \\
\text { Guideline. } \\
\text { At bidrage til OECDs arbejde } \\
\text { med nanomaterialer. } \\
\text { At give indpil til } \\
\text { Montrealprotokollen om ozon. } \\
\text { At skabe baggrundsmaterialer, } \\
\text { undersøgelser og viden om }\end{array}$ \\
& & $\begin{array}{l}\text { ovenstående. } \\
\text { At udvikle viden om } \\
\text { omkostningerne for de nordiske } \\
\text { samfund ved hormonforstyrrende } \\
\text { stoffer i rapporten ”The Cost of } \\
\text { Inaction”. }\end{array}$ \\
\hline
\end{tabular}




\section{8-3312 Nordisk Råds miljøpris}

Programlignende aktiviteter
\begin{tabular}{|l|c|c|c|c|c|} 
Valuta & Budget 2016 & Budget 2015 & Budget 2014 & Disp./bud. 14 & Budget disp. af \\
\hline DKK & 600.000 & 609.000 & 0 & $0 \%$ & MR-M/EK-M
\end{tabular}

Formål $\quad$ Formålet med Miljøprisen er å øke interessen for det nordiske miljøsamarbeidet, samt å annerkjenne enestående miljømessige innsatser. Prisen skal bidra til å markere det formelle nordiske miljøsamarbeidet.

En evaluering av Nordisk Råds natur- og miljøpris forventes avsluttet høsten 2015. De endringer som MR-M/EK-M beslutter som følge av denne evaluering skal inkorporeres i anvendelsen av de bevilgede midlene, dvs. administrasjon og utdeling av Nordisk råds natur- og miljøpris, samt til synliggjøring og profilering av prisen.

Forvaltnings- Stortinget, Internasjonal Avdeling, Norge organ

\begin{tabular}{|c|c|c|}
\hline \multicolumn{3}{|l|}{ Mål og resultatopfølgning } \\
\hline 2016 - Mål & 2015 - Mål & 2014 - Opnåede resultater \\
\hline $\begin{array}{l}\text { Målet er å fremme den viktige } \\
\text { satsningen som Nordisk råds } \\
\text { natur- og miljøpris representerer } \\
\text { innenfor miljøsamarbeidet, skape } \\
\text { synlighet av prisen i samarbeid } \\
\text { med de andre Nordisk råds priser } \\
\text { samt synliggjøre og profilere } \\
\text { prisen som en del av de nordiske } \\
\text { miljøministrenes samarbeid. }\end{array}$ & $\begin{array}{l}\text { Godkjennelse av nye vedtekter av } \\
\text { ministrene under Sesjonen 2015, } \\
\text { samt utdelelse av miljøprisen } \\
2015 \text {. }\end{array}$ & $\begin{array}{l}\text { Konkretisering av nye vedtekter, } \\
\text { samt utdeling av miljøprisen } \\
2014 .\end{array}$ \\
\hline
\end{tabular}

\section{8-3320 NEFCOS Miljøudviklingsfond}

Programlignende aktiviteter
\begin{tabular}{|l|c|c|c|c|c|} 
Valuta & Budget 2016 & Budget 2015 & Budget 2014 & Disp./bud. 14 & Budget disp. af \\
\hline DKK & 11.016 .000 & 11.016 .000 & 11.297 .000 & $100 \%$ & NEFCO
\end{tabular}

Formål Nordisk miljøudviklingsfond (NMF) startede i 1996. NMF administreres af det Nordiske miljøfinansieringsselskab, NEFCO, hvis primære formål er at fremme investeringer af nordisk miljøinteresse i Central- og Østeuropa ved at finansiere virksomheder i disse lande. Nordisk Ministerråd bidrager direkte med midler til NMF og indirekte via miljøudviklingsfonden som bl.a. anvendes til NMF Krediter og Barents Hot Spots Facility (BHSF).

Miljøudviklingsfonden er rettet mod at opnå positive miljøeffekter gennem at styrke lønsomheden for aktuelle miljøprojekter, muliggøre større risikotagning ved finansiering, fremskynde projekters gennemførelse eller udvikle nye miljøinvesteringer.

NMF's virksomhed bidrager til miljøforbedrende foranstaltninger indenfor renere produktion, energieffektivisering og landbrug, samt gennemførelse af projekter for at reducere udslippet af miljøgifter i Østersøen. 
Forvaltnings- $\quad$ NEFCO, Nordic Environment Finance Corporation organ

\begin{tabular}{|c|c|c|}
\hline \multicolumn{3}{|l|}{ Mål og resultatopfølgning } \\
\hline 2016 - Mål & 2015 - Mål & 2014 - Opnåede resultater \\
\hline $\begin{array}{l}\text { På grund af den politiske } \\
\text { situationen i Ukraine og Rusland } \\
\text { vil fokus på projekter om } \\
\text { energieffektivisering øges. } \\
\text { Forsat prioriteres finansiering af } \\
\text { projekter indenfor renere } \\
\text { produktion i den private sektor, } \\
\text { energibesparelser i den offentlige } \\
\text { sektor, at styrke arbejdet omkring } \\
\text { renere miljø i Barents regionen } \\
\text { (Barents Hot spot), reduktion af } \\
\text { miljøgifte i Arktis og reduktion af } \\
\text { udslip fra landbruget til havet } \\
\text { gennem blandt andet håndtering } \\
\text { af gødning. } \\
\text { Opfølgning af NEFCOs strategi. } \\
\text { Den økonomiske målsætning for } \\
\text { år } 2016 \text { er at godkende projekter } \\
\text { for } 23 \text { millioner DKK. }\end{array}$ & $\begin{array}{l}\text { At fortsat arbejde med miljøpro- } \\
\text { jekter indenfor den arktiske regi- } \\
\text { on med særlig fokus på miljøgifte } \\
\text { og finansiering af renere produk- } \\
\text { tionsprojekt i den private sektor, } \\
\text { finansiering af energibesparings- } \\
\text { projekter i den offentlige sektor } \\
\text { og eliminering af Barents Hot } \\
\text { Spots. Derudover vil projekter } \\
\text { indenfor finansiering af projekter } \\
\text { for at reducere udslip fra land- } \\
\text { bruget være i fokus. } \\
\text { Den økonomiske målsætning er } \\
\text { at godkende projekter for } 23 \text { mil- } \\
\text { joner DKK. }\end{array}$ & $\begin{array}{l}\text { Under } 2014 \text { godkendte NMF og } \\
\text { NMF Krediter } 23 \text { nye projekter. } \\
\text { Af disse lå } 11 \text { indenfor rammen } \\
\text { af låneprogrammet for } \\
\text { energibesparelseprojekter og } 5 \\
\text { projekter under programmet for } \\
\text { renere produktion. Antallet } \\
\text { gennemførte, aftalte og } \\
\text { godkendte projekter er i alt } 272 . \\
\text { Dertil kommer } 70 \text { projekter som } \\
\text { er godkendt under Barents Hot } \\
\text { Spots Falicity (BHSF), som } \\
\text { finansieres delvis med midler fra } \\
\text { NMF. } \\
\text { Tilsammen er } 177 \text { projekt under } \\
\text { fonden blevet gennemført, mens } \\
9 \text { er blevet stoppet. Projekter } \\
\text { under fonden bidrager direkte og } \\
\text { indirekte til reduktioner af bl. a. } \\
\text { kuldioxid, nitrogen/kvælstof, } \\
\text { nitrogenmonooxid, fosfor og } \\
\text { svovldioxid. }\end{array}$ \\
\hline
\end{tabular}

8-6720 SVANEN - Nordisk Miljömärkning

Organisationsbidrag
\begin{tabular}{|l|c|c|c|c|c|} 
Valuta & Budget 2016 & Budget 2015 & Budget 2014 & Disp./bud. 14 & Budget disp. af \\
\hline DKK & 4.199 .000 & 4.199 .000 & 4.137 .000 & $100 \%$ & $\begin{array}{c}\text { Nordiska } \\
\text { miljömärkningsnäm } \\
\text { nden }\end{array}$
\end{tabular}

Formål

Det nordiska miljömärket Svanen är de nordiska ländernas officiella miljömärkning av varor och tjänster. En frivillig gemensam nordisk miljömärkning möjliggör medvetna och miljövänliga konsumentval och medverkar till att minska den belastning som den dagliga konsumtionen orsakar för miljön.

Alla centrala beslut om det nordiska miljömärket Svanen, såsom principer och regler för verksamheten och fastställandet av kriterier, ska göras på nordisk nivå. Vidare är det viktigt att verksamheten i samtliga nordiska länder utförs enligt samma principer. Konsumenter och producenter ska kunna känna igen Svanen som ett gemensamt nordiskt miljömärke.

Det nordiska miljömärket Svanen regleras av Nordiska ministerrådet genom Mål och principer för det nordiska miljömärket Svanen och Nordiska miljömärkningsnämndens verksamhet och uppgifter definieras närmare i Arbetsordningen för Nordiska miljömärkningsnämnden. Nordiska miljömärkningsnämnden antar Regler för Nordisk miljö - 
märkning samt fleråriga strategier för Svanens verksa mhet.

Forvaltnings- Föreningen Nordisk Miljömärkning organ

\begin{tabular}{|c|c|c|}
\hline \multicolumn{3}{|l|}{ Mål og resultatopfølgning } \\
\hline 2016 - Mål & 2015 - Mål & 2014 - Opnåede resultater \\
\hline $\begin{array}{l}\text { Svanen digitaliseras ytterligare, } \\
\text { för ökad användarvänlighet och } \\
\text { effektivitet för såväl } \\
\text { verksamheter som konsumenter } \\
\text { på ett samnordiskt plan. } \\
\text { Svanen utnyttjar sin potential } \\
\text { genom att nya produktområden } \\
\text { fås med i programmet; kriterier } \\
\text { inom två nya } \\
\text { branscher/områden beslutas } \\
\text { under året. } \\
\text { Ett tvärsgående dokument } \\
\text { utvecklas och publiceras för att } \\
\text { uppvisa Svanens överordnade } \\
\text { miljöstrategi. } \\
\text { Marknadsarbetet i Norden } \\
\text { samordnas för att Svanen som } \\
\text { instrument för producenter ska } \\
\text { uppfattas som enhetligt. } \\
\text { Insatser och utvecklingsarbete } \\
\text { ska göras för att klargöra } \\
\text { Svanens roll inom offentlig } \\
\text { upphandling och underlätta för } \\
\text { nordiska upphandlare och } \\
\text { leverantörer att använda } \\
\text { märkningen, både vid } \\
\text { kravställande och vid } \\
\text { verifikation. } \\
\text { Licensiering inom Svanen ska } \\
\text { utvecklas och koordineras } \\
\text { nordiskt för bästa effektivitet } \\
\text { och för att säkra likabehandling } \\
\text { av sökande verksamheter. } \\
\text { Svanen kommuniceras på den } \\
\text { internationella arenan som ett } \\
\text { globalt föredöme och som ett } \\
\text { exempel på nordiskt samarbete, } \\
\text { miljöengagemang och } \\
\text { miljötekniskt kunnande. }\end{array}$ & $\begin{array}{l}\text { Planer fastställs för uppföljning } \\
\text { av beslut i MR-M om resultatet } \\
\text { av visionsarbetet Svanen } 2015 . \\
\text { Strategin för 2016-2020 besluts av } \\
\text { Nordiska Miljömärknings- } \\
\text { nämnden (NMN). } \\
\text { Föreningen "Nordisk Miljömärk- } \\
\text { ning" framstår som den centrala } \\
\text { samarbetspunkten mellan länder- } \\
\text { nas verksamheter och samordnare } \\
\text { av verksamheten i sin helhet. } \\
\text { En gemensam nordisk digitali- } \\
\text { serad samling av all information } \\
\text { om produkter, kunder och kon- } \\
\text { takter har etablerats. } \\
\text { Nya produktområden fås med i } \\
\text { programmet. Två nya kriterier } \\
\text { läggs fram. } \\
\text { Efter att samordningen nordiskt } \\
\text { har genomförts för kriteriearbetet } \\
\text { och licensieringsprocessen eta- } \\
\text { bleras nu mer samordnat mark- } \\
\text { nadsarbete. } \\
\text { Erfarenheterna av Svanen förs ut } \\
\text { på den internationella arenan som } \\
\text { profilering av nordiskt samarbete. }\end{array}$ & $\begin{array}{l}\text { Samtliga kriterier och } \\
\text { ansökningshjälp finns nu samlat } \\
\text { på den engelska hemsidan } \\
\text { www.nordic-ecolabel.org. } \\
\text { Vägledare för energi- och } \\
\text { klimatkrav i kriteriearbetet var } \\
\text { färdig våren. } \\
\text { Svanen har under } \\
\text { kriterieutvecklingen haft stort } \\
\text { fokus på energikrav och därmed } \\
\text { på klimataspekterna av } \\
\text { produktion och konsumtion. } \\
\text { Detta i kombination med att } \\
\text { Svanen under året marknadsförts } \\
\text { som ett helhetsmärke, } \\
\text { inkluderande klimatfrågan, har } \\
\text { bidragit till att ingen separat } \\
\text { klimatmärkning har etablerats i } \\
\text { de nordiska länderna, vilken } \\
\text { NMN såg som viktigt strategiskt } \\
\text { mål. I Norden anser nu } 55 \text { \% att } \\
\text { Svanen är ett märke för ett ”bra } \\
\text { klimatval”. } \\
\text { Svanen har reviderat sin } \\
\text { miljögiftspolicy som fokuserar } \\
\text { på hälsa- och miljöfarliga } \\
\text { kemikalier. } \\
\text { Alla } \\
\text { miljömärkningsorganisationer har } \\
\text { nu ett gemensam IT-plattform } \\
\text { och befinner sig på samma server } \\
\text { på Island. En gemensam nordisk } \\
\text { licensdatabas och CRM } \\
\text { (kundhanteringssystem) har } \\
\text { lanserats och implementerats. } \\
\text { Alla } \\
\text { miljömärkningsorganisationer har } \\
\text { nu startat upp ett nätverk för } \\
\text { privata inköpare och offentliga } \\
\text { upphandlare i syfte att öka } \\
\text { efterfrågan på svanenmärkta } \\
\text { produkter. }\end{array}$ \\
\hline
\end{tabular}




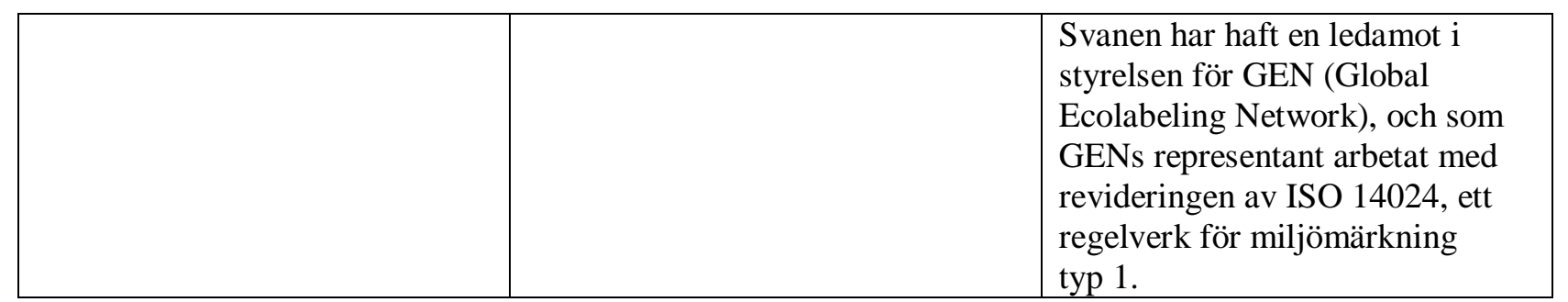




\section{Arbetslivspolitik}

\section{Generel indledning}

Formål og Det nordiska arbetslivssamarbetet är inriktat på att analysera centrala frågeställningar, Fakta samordna och utbyta erfarenheter kring ländernas arbetslivspolitik. Aktiviteterna ska bidra till att säkra och vidareutveckla en välfungerande nordisk arbetsmarknad och ett gott arbetsliv i ett konkurrenskraftigt Norden. MR-A har ställt upp ett antal gemensamma mål för arbetsmarknads-, arbetsmiljö- och arbetsrättsområdet samt ett antal tvärgående prioriteringar. Tillsammans skapar det ramarna för det nordiska samarbetet på arbetslivsområdet.

Samarbetet organiseras av Ämbetsmannakommittén för arbetsliv (ÄK-A), som ger riktlinjerna och fördelar MR-A:s budget mellan kommitténs tre utskott samt till Nordjobb, NIVA och budgetposten "Kommunikation om arbetsliv".

Strategiske målsætninger 2016
De strategiska målsättningarna följer det samarbetsprogram som utarbetats för åren 2013-2016. Under perioden har fokus lagts vid de långsiktiga utmaningar som följer av globaliseringen och den demografiska utvecklingen. Arbetet kommer att utgå från det finska ordförandeskapsprioriteringarna.

Den strategiska genomlysningen som inletts i A-sektorn väntas resultera i ett antal rekommendationer som berör innehållet och inriktningen på det fortsatta arbetslivssamarbetet i Norden. Under året väntas länderna förhålla sig till dessa rekommendationer och besluta hur arbetet ska drivas vidare.

Samarbetet på sysselsättnings- och arbetsmarknadsområdet ska understödja den gemensamma strävan att öka arbetskraftsutbudet, stärka sysselsättningen och reducera den strukturella arbetslösheten för både kvinnor och män. Ländernas mål är att mobilisera inhemska arbetskraftsresurser, stärka matchningen av utbud och efterfrågan på arbetskraft, främja livslångt lärande efter arbetsmarknadens behov, främja attraktionskraften hos arbetskraft i länder utanför EU/EES i förhållande till efterfrågan, främja koordineringen mellan relevanta myndigheter samt att bekämpa arbetslöshet bland utsatta grupper särskilt långtidsarbetslösa och unga.

På arbetsmiljöområdet är samarbetet inriktat på att understödja ländernas politik för säkerhet, hälsa och välfärd i arbetslivet för både kvinnor och män. Syftet är att skapa en arbetsmiljö som är attraktiv, motiverande och inkluderande, och som förebygger arbetsrelaterade fysiska och psykiska hälsoproblem. Samtidigt ska den vara utformad med hänsyn till internationella avtal och EU:s regelverk. Målet är att stärka en god arbetsmiljö på arbetsplatserna, vidareutveckla arbetsmiljöstrategier och -tillsyn, motverka oacceptabla arbetsförhållanden, ”social dumpning” och diskriminering på arbetsmarknaden. Målet är också att synliggöra betydelsen av gott ledarskap, aktivt medarbetarinflytande samt att tillvarata enskilda arbetstagares resurser.

Inom arbetsrättsområdet prioriteras arbetet med att följa upp villkoren för den nordiska modellen, dess utmaningar och anpassningsbehov samt belysa hur den kan upprätthållas och utvecklas i ett alltmer globaliserat arbets- och näringsliv. Utgångspunkter för det nordiska samarbetet är att säkra en rimlig balans mellan löntagarskydd och flexibilitet, främja jämställdhet och likabehandling på arbetsmarknaden samt att stärka det nordiska samarbetet i förhållande till internationella regler, i synnerhet i EU.

Ett tvärgående prioriteringsområde är att främja geografisk mobilitet och anpassningsförmåga genom att förebygga och undanröja gränshinder på den nordiska 
arbetsmarknaden.

Ytterligare teman som följer upp mera aktuella politiska och fackliga utmaningar kommer under perioden läggas fast närmare respektive ordförandeskaps sektorsprogram samt i utskottens verksamhetsplaner och temaupplägg.

Ministerrådets resultater i 2014
I maj avhölls en särskild jubileumskonferens i Reykjavik som uppmärksammade att det gått 60 år sedan den öppna nordiska arbetsmarknaden skapades. Under året fattade arbetsmarknadsministrarna beslut om att genomföra en strategisk genomlysning av arbetslivssektorn som ett led i det moderniseringsarbete som NMR genomför.

\section{Arbetsmiljöutskottet}

Utskottet fokuserade på tre teman under året; arbetsmiljöstrategier och tillsyn i de nordiska länderna; samband mellan ledarskap och arbetsmiljö samt säker arbetsmiljö under hela yrkeslivet. Under dessa teman igångsattes tre nya projekt som löper vidare under 2015. En uppskattad konferens om god arbetsmiljö genom hela arbetslivet med fokus på bl. a. samspelet mellan arbetsmiljö och ålder hölls i oktober. Fem projekt avslutades under 2014. Särskilt intressant var ett ambitiöst och unikt projekt som analyserade kopplingen mellan arbetsmiljö och produktivitet i de nordiska länderna. Studien visar att det finns ett robust positivt samband mellan god fysisk arbetsmiljö och hög produktivitet i alla länder.

\section{Arbetsmarknadsutskottet}

Utskottet fokuserade särskilt på gränshindersfrågor och arbetskraftsmobilitet i Norden, samt informationsutväxling mellan länderna kring arbetsmarknadspolitik och bekämpning av ungdomsarbetslöshet. Utskottet finansierade och igångsatte ett projekt om arbetsmarknadsutbildning i Norden i syfte att ge en helhetsbild hur länderna organiserar utbildningsinsatser för arbetslösa samt deltog i tre tvärsektoriella projekt.

\section{Arbetsrättsutskottet}

Utskottet fokuserade 2014 på ”Employment relations” och minimilöner. Projektet ”Europa och den nordiska aftalsmodelen” påbörjades också under 2014.

\section{Nordjobb}

Nordjobb uppnådde sitt primära mål när det gäller förmedlade arbetsplatser under året. Vid sidan av att förmedla ett förutbestämt antal jobb kunde Nordjobb bredda målgruppen dels till nyutexaminerade samt ungdomar som står utanför arbetsmarknaden och skola. Samtidigt har arbetet fortsatt för att öka differentieringen av Nordjobbs finansiering.

\section{NIVA}

NIVA fortsatte den löpande kursverksamheten under året och uppfyllde de uppsatta målen vad beträffat deltagande och kvalitet. Kursen "Occupational Skin Diseases” fick särskilt goda vitsord från deltagarna. Ett nytt ettårigt kontrakt upprättades i avvaktan på att den nya strategin kommer på plats under 2015.

\section{Kommunikation om arbetsliv}

Utgivningen av nyhetsbreven "Arbejdsliv i Norden” och "EU \& Arbetsrätt” samt andra publikationer och pressmeddelanden främjade kunskap om arbetslivsfrågor och det nordiska arbetslivssamarbetet hos relevanta hos relevanta målgrupper såväl i Norden som internationellt. Antalet läsare av den webbaserade tidskriften "Arbejdsliv i Norden” ökade med 37 procent under hösten 2014. 


\begin{tabular}{|c|c|c|c|c|c|}
\hline & \multirow{2}{*}{$\begin{array}{r}\text { Budget } \\
2016\end{array}$} & \multirow{2}{*}{$\begin{array}{r}\text { Budget } \\
2015\end{array}$} & \multicolumn{2}{|c|}{ Difference } \\
\hline & & & & $+/-$ & $\%$ \\
\hline \multicolumn{2}{|c|}{ MR-A (TDKK) } & 13.632 & 13.632 & $\mathbf{0}$ & $0,0 \%$ \\
\hline & Projektmedel & 10.262 & 10.262 & 0 & $0,0 \%$ \\
\hline $9-4110$ & Projektmidler i øvrigt - Arbejdsliv & 907 & 907 & 0 & $0,0 \%$ \\
\hline 9-4111 & Arbejdsliv faste udvalg & 4.583 & 4.583 & 0 & $0,0 \%$ \\
\hline $9-4120$ & Nordjobb & 3.160 & 3.160 & 0 & $0,0 \%$ \\
\hline \multirow[t]{2}{*}{$9-4130$} & Kommunikation om arbejdsliv & 1.612 & 1.612 & 0 & $0,0 \%$ \\
\hline & Institutioner & 3.370 & 3.370 & 0 & $0,0 \%$ \\
\hline $9-4180$ & Institut för vidareutb.inom arbetsmiljö (NIVA) & 3.370 & 3.370 & 0 & $0,0 \%$ \\
\hline \multicolumn{2}{|c|}{ Opdelt på kategorier } & 13.632 & 13.632 & $100 \%$ & $100 \%$ \\
\hline & Projektmidler & 2.519 & 2.519 & $18,5 \%$ & $18,5 \%$ \\
\hline & Programlignende aktiviteter & 7.743 & 7.743 & $56,8 \%$ & $56,8 \%$ \\
\hline & Institutioner & 3.370 & 3.370 & $24,7 \%$ & $24,7 \%$ \\
\hline
\end{tabular}

\section{$\underline{\text { 9-4110 Projektmedel i övrigt - Arbetsliv }}$}

Projektmidler
\begin{tabular}{|l|c|c|c|c|c|} 
Valuta & Budget 2016 & Budget 2015 & Budget 2014 & Disp./bud. 14 & Budget disp. af \\
\hline DKK & 907.000 & 907.000 & 694.000 & $100 \%$ & EK-A
\end{tabular}

Formål Projektmedel i övrigt används bland annat till att genomföra ordförandeskapet prioriteringar i arbetslivssektorn och ÄK-A:s driftsbudget.

\begin{tabular}{|c|c|c|}
\hline \multicolumn{3}{|l|}{ Mål og resultatopfølgning } \\
\hline 2016 - Mål & 2015 - Mål & 2014 - Opnåede resultater \\
\hline $\begin{array}{l}\text { Ett framgångsrikt } \\
\text { genomförande av det finska } \\
\text { ordförandeskapet i A-sektorn. } \\
\text { Fortsatt genomförande av } \\
\text { samarbetsprogrammet och } \\
\text { dess prioriteringar. } \\
\text { Genomlysningen av A-sektorn } \\
\text { slutförs under året. Eventuellt } \\
\text { påbörjas implementering av } \\
\text { genomlysningens förslag. }\end{array}$ & $\begin{array}{l}\text { Tre större } \\
\text { ordförandeskapsaktiviteter } \\
\text { kommer att genomföras: } \\
\text { Konferens i mars om att } \\
\text { bekämpa ungdomsarbetslöshet, } \\
\text { trepartsexpertseminarium i april } \\
\text { om att motverka social dumping, } \\
\text { konferensen "Baredygtigt } \\
\text { arbejdsmarked i Nordens } \\
\text { udkantsmråder" hålls i augusti. }\end{array}$ & $\begin{array}{l}\text { Ett MR-A möte avhölls i Köpenhamn } \\
\text { i november } 2014 . \\
\text { Under det isländska ordförandeskapet } \\
\text { genomfördes flera konkreta } \\
\text { aktiviteter i form av temakonferenser } \\
\text { kring jämställdhet, arbetsmiljö genom } \\
\text { hela arbetslivet och lärande för livet. } \\
\text { Konferenserna var generellt lyckade } \\
\text { med högt deltagande. Särskilt } \\
\text { uppmärksammad blev } \\
\text { jubileumskonferensen i anledning av } \\
\text { den gemensamma nordiska } \\
\text { arbetsmarknadens 60-årsjubileum. } \\
\text { Speciellt värdefulla var } \\
\text { diskussionerna kring de framtida } \\
\text { utmaningar som den gemensamma } \\
\text { arbetsmarknaden står inför. } \\
\text { Ministerbeslut och förberedande } \\
\text { arbete med att genomföra en } \\
\text { strategisk genomlysning av A- } \\
\text { sektorn. }\end{array}$ \\
\hline
\end{tabular}


$\underline{9-4111 \text { Arbetslivs fasta utskott }}$

Programlignende aktiviteter

\begin{tabular}{|l|c|c|c|c|c|} 
Valuta & Budget 2016 & Budget 2015 & Budget 2014 & Disp./bud. 14 & Budget disp. af \\
\hline DKK & 4.583 .000 & 4.583 .000 & 4.989 .000 & $85 \%$ & EK-A
\end{tabular}

Formål $\quad$ ÄK-A delegerar ansvaret för fördelning och användning av sektorns projektmedel till arbetsmarknads-, arbetsmiljö- respektive arbetsrättsutskotten i enlighet med samarbetsprogrammet och utskottens verksamhetsplaner. De externa sekreterarna i de tre utskotten finanseras också under budgetposten.

\begin{tabular}{|c|c|c|}
\hline \multicolumn{3}{|l|}{ Mål og resultatopfølgning } \\
\hline 2016 - Mål & 2015 - Mål & 2014 - Opnåede resultater \\
\hline $\begin{array}{l}\text { Inom arbetsmiljösamarbetet är } \\
\text { målet att fortsätta stödja de } \\
\text { nordiska ländernas politik för att } \\
\text { skapa en arbetsmiljö som är } \\
\text { attraktiv, motiverande och } \\
\text { inkluderande samt att förebygga } \\
\text { arbetsrelaterade hälsoproblem. } \\
\text { Arbetsmarknadsutskottets mål är } \\
\text { att främja kunskap för } \\
\text { vidareutveckling och } \\
\text { modernisering av } \\
\text { arbetsmarknadspolitiken i } \\
\text { Norden. Ett specifikt projekt som } \\
\text { genomförs under året behandlar } \\
\text { arbetsförmedlingstjänster. } \\
\text { Arbetsrättsutskottet kommer följa } \\
\text { upp villkoren för den nordiska } \\
\text { modellen, dess utmaningar och } \\
\text { anpassningsbehov samt belysa } \\
\text { hur den kan upprätthållas och } \\
\text { utvecklas i ett alltmer globaliserat } \\
\text { arbets- och näringsliv. }\end{array}$ & $\begin{array}{l}\text { Målen i arbetsmiljöarbetet har } \\
\text { fokuserat på att främja } \\
\text { vidareutveckling av } \\
\text { arbetsmiljöstrategier och relevant } \\
\text { kunskap för ländernas } \\
\text { tillsynverksamhet samt att } \\
\text { tydliggöra arbetsmiljöns } \\
\text { betydelse för äldre arbetstagares } \\
\text { förmåga att kvarstå i arbetslivet. } \\
\text { Arbetsmarknadsutskottet ska } \\
\text { bidra till en fortsatt } \\
\text { modernisering av } \\
\text { arbetsmarknadspolitiken i } \\
\text { Norden. Under året kommer } \\
\text { exempelvis slutrapporter } \\
\text { presenteras om } \\
\text { arbetsmarknadsutbildningar i } \\
\text { Norden samt en större studie om } \\
\text { ungdomsarbetslöshet i de } \\
\text { nordiska länderna. } \\
\text { Under } 2015 \text { förväntas } \\
\text { arbetsrättsutskottet särskilt se } \\
\text { närmare på implementering av } \\
\text { tillämpningsdirektivet, } \\
\text { kartläggning av utstationerad } \\
\text { arbetskraft i de nordiska länderna } \\
\text { samt dryfta aktuella teman i de } \\
\text { nordiska länderna. } \\
\text { Under året kommer utskotten } \\
\text { beröras av genomlysningen. }\end{array}$ & $\begin{array}{l}\text { Under året fokuserade } \\
\text { arbetsmiljöutskottet på att } \\
\text { vidareutveckla } \\
\text { arbetsmiljöstrategier och tillsyn, } \\
\text { sambandet ledarskap - } \\
\text { arbetsmiljö samt god arbetsmiljö } \\
\text { genom hela livet. Tre projekt } \\
\text { finansierades under dessa } \\
\text { prioriteringar. Ett särskilt } \\
\text { intressant projekt som avslutades } \\
\text { visade på ett positivt samband } \\
\text { mellan god fysisk arbetsmiljö och } \\
\text { hög produktivitet i de nordiska } \\
\text { länderna. } \\
\text { Arbetsmarknadsutskottet har } \\
\text { medverkat till förbättrad } \\
\text { förståelse av mobiliseringen av } \\
\text { arbetskraften i Norden, med } \\
\text { särskilt fokus på } \\
\text { ungdomsarbetslöshet, bland annat } \\
\text { genom ett större projekt om } \\
\text { ungdomsarbetslöshet. Man har } \\
\text { även fortsatt stötta The } \\
\text { Programme for the International } \\
\text { Assessment of Adult } \\
\text { Competencies (PIAAC) projektet } \\
\text { angående data att beskriva och } \\
\text { jämföra grundläggande } \\
\text { kunskaper och färdigheter hos } \\
\text { vuxna med koppling till } \\
\text { arbetslivet. } \\
\text { Arbetsrättsutskottet har under } \\
\text { året diskuterat ”Employment } \\
\text { relations” samt minimilöner. Man } \\
\text { har även påbörjat projektet om } \\
\text { ”Europa och den nordiska } \\
\text { avtalsmodellen”. }\end{array}$ \\
\hline
\end{tabular}




\section{$\underline{9-4120 \text { Nordjobb }}$}

Programlignende aktiviteter
\begin{tabular}{|l|c|c|c|c|c|} 
Valuta & Budget 2016 & Budget 2015 & Budget 2014 & Disp./bud. 14 & Budget disp. af \\
\hline DKK & 3.160 .000 & 3.160 .000 & 3.113 .000 & $97 \%$ & FNF
\end{tabular}

Formål Nordjobb arbetar för att öka mobiliteten för unga på den nordiska arbetsmarknaden och för att försöka förbättra språkkunskaper och kunskapen om kultur i Norden. Nordjobb förmedlar i första hand sommarjobb, bostad samt kultur- och fritidsprogram för ungdomar mellan 18-28 år.

Forvaltnings- $\quad$ Föreningen Nordens Förbund (sekretariatsfunktion) organ

\begin{tabular}{|c|c|c|}
\hline \multicolumn{3}{|l|}{ Mål og resultatopfølgning } \\
\hline 2016 - Mål & 2015 - Mål & 2014 - Opnåede resultater \\
\hline $\begin{array}{l}\text { Under } 2016 \text { kommer Nordjobb } \\
\text { att arbeta för att uppnå sitt } \\
\text { primära mål när det gäller } \\
\text { förmedlade arbetsplatser. En } \\
\text { tydlig inriktning är att nå ut till en } \\
\text { målgrupp som är så bred som } \\
\text { möjligt och att arbeta för en mer } \\
\text { differentierad finansiering. } \\
\text { Ett nytt kontrakt ska tas fram } \\
\text { efter att Nordjobb har } \\
\text { utvärderats. }\end{array}$ & $\begin{array}{l}\text { Under } 2015 \text { kommer Nordjobb } \\
\text { att arbeta för att uppnå sitt } \\
\text { primära mål när det gäller } \\
\text { förmedlade arbetsplatser. En } \\
\text { tydlig inriktning är att nå ut till en } \\
\text { målgrupp som är så bred som } \\
\text { möjligt och att arbeta för en mer } \\
\text { differentierad finansiering. }\end{array}$ & $\begin{array}{l}\text { Nordjobb uppnådde sitt primära } \\
\text { mål när det gäller förmedlade } \\
\text { arbetsplatser under året. En tydlig } \\
\text { inriktning var att uppnå resultatet } \\
\text { samtidigt som man nådde ut till } \\
\text { en så bred målgrupp som möjligt. } \\
\text { Där kan bl.a. nämnas projektet } \\
\text { Nordisk Jobstart som har arbetat } \\
\text { med gruppen dimententer } \\
\text { (nyutexaminerade personer från } \\
\text { eftergymnasiala utbildningar) och } \\
\text { projektet Entreprenörskap över } \\
\text { gränser som har arbetat med } \\
\text { Neets-gruppen, (Not in } \\
\text { Employment, Education or } \\
\text { Training). } \\
\text { Nordjobb informerade vid möten } \\
\text { med kommuner och nordiska } \\
\text { arbetsgivare om ”Jobbresan” som } \\
\text { modell för att hjälpa unga att hitta } \\
\text { sysselsättning. }\end{array}$ \\
\hline
\end{tabular}

\section{$\underline{\text { 9-4130 Kommunikation om arbetsliv }}$}

Projektmidler

\begin{tabular}{|l|c|c|c|c|c|} 
Valuta & Budget 2016 & Budget 2015 & Budget 2014 & Disp./bud. 14 & Budget disp. af \\
\hline DKK & 1.612 .000 & 1.612 .000 & 1.588 .000 & $96 \%$ & EK-A
\end{tabular}

Formål Syftet är att öka kunskapen om det nordiska arbetslivet inom och utanför Norden.

\begin{tabular}{|l|l|l|}
\hline \multicolumn{2}{|l|}{ Mål og resultatopfølgning } & 2014 - Opnåede resultater \\
\hline 2016 - Mål & 2015 - Mål & Webmagasinet Arbejdsliv $i$ \\
\hline $\begin{array}{l}\text { Målet är att bidra till att genom- } \\
\text { föra Informations- och kommu- }\end{array}$ & $\begin{array}{l}\text { Målet är att bidra till att } \\
\text { genomföra arbetslivssektorns }\end{array}$ & Norden har under 2014 ökat \\
\hline
\end{tabular}


nikationsstrategin för 2013-16 som har fokus på tre målsättningararbetslivssektorns kommunikationsinsatser som syftar till: 1 . Stärka synligheten och relevansen av det nordiska samarbetet 2. Öka tillgängligheten av relevant information 3. Bidra till att stärka debatten om utvecklingen på arbetslivsområdet. kommunikationsinsatser som syftar till: 1 . Stärka synligheten och relevansen av det nordiska samarbetet 2. Öka tillgängligheten av relevant information 3. Bidra till att stärka debatten om utvecklingen på arbetslivsområdet.

Modernisering av hemsidan för Arbejdsliv i Norden påbörjas. kunskapen om det nordiska arbetslivet genom bland annat höjt läsartal på både den skandinaviska som engelska utgåvan.

Nyhetsbrevet EU \& Arbetsrätt har i 2014 ökat kunskapen om arbetsrätt i ett europeiskt perspektiv. Nyhetsbrevet har i ljuset av sitt specifika fokus många prenumeranter av både den elektroniska upplagan som den tryckta versionen.

\section{9-4180 Nordiska Institututionen för Vidareutbildning inom Arbetsmiljöområdet (NIVA)}

Institution
\begin{tabular}{|l|c|c|c|c|c|} 
Valuta & Budget 2016 & Budget 2015 & Budget 2014 & NMR fin. 14 & Budget disp. af \\
\hline EUR & 451.800 & 451.800 & 444.200 & $74 \%$ & Institutionen \\
\hline Modsv. DKK & 3.370 .000 & 3.370 .000 & 3.314 .000 & &
\end{tabular}

Formål

NIVA:s främsta uppgift är att vara ett forum för kunskapsspridning inom området arbetshälsa och arbetsmiljö. NIVA skapar nordiskt mervärde genom att organisera kurser, symposier, workshops och seminarier på avancerad nivå till hög kvalitet speciellt på områden där det saknas tillräcklig kritisk massa i ett enskilt land.

Kontraktperiode Nuvarande kontraktsperiod löper ut i slutet av 2015 och ska därefter förnyas. og status

\begin{tabular}{|c|c|c|}
\hline \multicolumn{3}{|l|}{ Mål og resultatopfølgning } \\
\hline 2016 - Mål & 2015 - Mål & 2014 - Opnåede resultater \\
\hline $\begin{array}{l}\text { NIVA ska fortsätta att utveckla } \\
\text { kursverksamheten inom området } \\
\text { arbetsmiljö och -hälsa för att } \\
\text { stärka det nordiska mervärdet i } \\
\text { enlighet med strategins } \\
\text { prioriteringar. Specifikt ska } \\
\text { kursutbudet diversifieras vad } \\
\text { gäller innehåll, längd och } \\
\text { målgrupper. NIVA:s ska ta sig } \\
\text { av nya utmaningar såsom behovet } \\
\text { att förlänga arbetskarriärer och } \\
\text { förebygga att individer lämnar } \\
\text { arbetslivet i förtid. Ett mål är } \\
\text { också att successivt bygga upp } \\
\text { nätverk via utökade } \\
\text { kommunikationsinsatser i syfte } \\
\text { att stärka NIVA:s relevans i det } \\
\text { nordiska arbetsmiljöarbetet. }\end{array}$ & $\begin{array}{l}\text { Mellan } 8 \text { - } 15 \text { kursaktiviteter med } \\
\text { sammantaget minst } 300 \text { deltagare } \\
\text { ska genomföras. Kursverksamheten } \\
\text { ska upprätthållas på avancerad nivå } \\
\text { och till hög kvalitet. NIVA ska } \\
\text { arbeta närmare med de nationella } \\
\text { arbetsmiljöinstituten och } \\
\text { motsvarande samt stärka nätverken } \\
\text { såväl i Norden som internationellt. } \\
\text { NIVA ska fortsätta sina } \\
\text { kontaktskapande aktiviteter och } \\
\text { antalet kurser inriktade på nordiska } \\
\text { och internationella deltagare. } \\
\text { NIVA ska vidare påbörja } \\
\text { implementering av sin nya strategi. } \\
\text { Ett nytt kontrakt ska också } \\
\text { utformas. }\end{array}$ & $\begin{array}{l}\text { NIVA genomförde } 13 \\
\text { kursaktiviteter på } \\
\text { arbetsmiljöområdet inklusive } \\
\text { en konferens i samarbete med } \\
\text { ordförandeskapet. Kurserna } \\
\text { fick generellt goda vitsord av } \\
\text { deltagarna och bidrog därmed } \\
\text { till att stärka det nordiska } \\
\text { arbetsmiljöarbetet. }\end{array}$ \\
\hline
\end{tabular}




\section{Ekonomi- og Finanspolitik}

\section{Generel indledning}

Formål og Det nordiska samarbetet på det ekonomiska och finansiella området ska bidra till att Fakta skapa förutsättningar för att de grundläggande ekonomisk-politiska målen om stabil ekonomisk utveckling med hög sysselsättning, sunda statsfinanser och uthållig tillväxt kan uppnås.

De konkreta målsättningarna syftar bland annat till att utveckla den nordiska välfärdsmodellen, att främja den ekonomiska integrationen i Norden, med Östersjöregionen och Europan i övrigt samt främja gemensamma nordiska ekonomiska och finansiella intressen internationellt. EU-frågor är högt prioriteradei det nordisk samarbetet.

Sektorns arbete understöds av ett antal samarbetsgrupper som den nordiska miljö- och ekonomigruppen, den nordiska konjunkturgruppen och den nordiska skattegruppen.

\section{Strategiske målsætninger 2016}

Ministerrådets resultater i 2014

\section{Ordförandeskapet}

Finland innehar ordförandeskapet 2016 med betoning på bl.a. att stärka informationsutväxlingen mellan de nordiska länderna och öka insikten bland de nordiska länderna kring centrala ekonomisk-politiska frågor.

Utgivning av nordisk ekonomisk-politisk forskningstidskrift Utgivningen av tidskriften NEPR, Nordic Economic Policy Review syftar till att presentera relevant forskning som belyser en eller flera aktuella ekonomisk-politiska frågeställningar som är relevant för beslutsfattare. Utgåvan 2016 väntas eventuellt bygga på finska ordförandeskapets prioriteringar.

\section{Gränshindersarbetet}

När det gäller gränshinder i Norden på det ekonomiska området fokuseras arbetet kring gränsöverskridande skattefrågor. Det finns ett kontinuerligt samarbete, dels genom den nordiska skatteportalen, dels genom bilaterala skatteprojekt. Ytterligare insatser väntas bli aktuella via samarbetet med Gränshinderrådet.

Miljömärkning av aktiefonder

Ett projekt inriktat på att analysera förutsättningarna för att miljömärka aktiefonder genom Svanensamarbetet kan bli aktuellt under 2015 och 2016. Preliminärt betraktar såväl marknadsaktörer och beslutsfattare projektet som välkommet. Projektet väntas utföras i nära samarbete mellan Finans- och Miljösektorerna. Det praktiska genomförandet av miljömärkningen kommer därefter att hanteras av av Nordiska miljömärkningsnämnden.

\section{Samarbete mot skatteflykt}

De gemensamma nordiska förhandlingarna om informationsutbytesavtal på skatteområdet avslutades framgångsrikt under 2014. De nordiska länderna har genom projektet upprättat nära nog ett heltäckande nät av skatteinformationsavtal. Under året tecknade de nordiska länderna avtal med Hongkong och de tekniska förhandlingarna med Förenade arabemiraten kunde slutföras. Det preleiminära resultatet för projektet som helhet innebär att betydande belopp i form av beskattningsbara kunnat återföras samt att skatteinstäkterna från tidigare oredovisat kapital har ökat.

Ekonomiska instrument i miljöpolitiken och genomförande av statsministrarnas uppdrag om grön tillväxt

Miljö- och ekonomigruppen, med gemensamt deltagande från Miljö- och 
Finanssektorerna har som huvudmål att bidra till en ekonomisk utveckling som bygger på hållbara produktions- och konsumtionsmönster och att miljöbelastning och ekonomisk tillväxt inte kopplas samman.

Underr 2014 fokuserade MEG på policyutvecklingen inom tre områden: ekonomiska styrmedel i miljöpolitiken, arbetet kring grön ekonomi samt ekosystemtjänster. MEG:s arbete resulterade i ett antal studier och rapporter som utgjorde värdefulla underlag för att belysa ekonomiska faktorer och styrmedel samt deras betydelse för miljön. Under 2014 publicerades bland annat en omfattande studie, The Use of Economic Instruments in Nordic Environmental Policy 2010-2013, samt Ecosystem Services In Nordic Freshwater Management med fokus på ekosystemtjänster.

Den förstnämnda rapporten ingick som en del i Finanssektorns arbete med att fullfölja statsministrarnas uppdrag att främja gröna investeringar. Den slutliga avrapporteringen kommer att ske under 2015.

Konkurrens som instrument för effektivisering av offentlig sektor Finansministrarna utbytte erfarenheter kring konkurrens som intrument föreffektivisering på basis av det underlag som ÄK-Finans tagit fram.

10-5210 Ekonomi- och Finanspolitik

Projektmidler
\begin{tabular}{|l|c|c|c|c|c|} 
Valuta & Budget 2016 & Budget 2015 & Budget 2014 & Disp./bud. 14 & Budget disp. af \\
\hline DKK & 1.810 .000 & 1.810 .000 & 1.819 .000 & $96 \%$ & EK-MR-Finans
\end{tabular}

Formål Stödja aktiviteter och intrument som underlättar för de nordiska länderna att uppnå de ekonomisk-politiska målen. 


\section{Lagstiftning}

\section{Generel indledning}

Formål og Formålet for justitssamarbejdet er at arbejde mod en ensartet retlig udvikling i Norden i Fakta overensstemmelse med Helsingforsaftales målsætninger og opfyldelse af Justitssektorens samarbejdsprogram.

Det konkrete samarbejde inden for justitssektoren omfatter bl.a. aktuelle politiske spørgsmål og opfølgning af fælles nordiske politiske prioriteter og beslutninger samt erfaringsudveksling og initiativer generelt inden for justitsministeriernes resort. Herudover indgår samarbejde med justitsministerierne og de retshåndhævende myndigheder i de baltiske stater i justitssektorens arbejde.

Udover det formaliserede nordiske samarbejde indenfor Justitssektoren findes et løbende praktisk samarbejde, idet der på embedsmandsniveau og i myndighedsregi afholdes kontaktmøder, seminarer, drøftelser m.v. om aktuelle retlige problemstillinger mellem de nordiske lande.

\section{Strategiske målsætninger 2016}

Ministerrådets resultater i 2014
Det retlige samarbejde skal i 2016 fortsat fokusere på udveksling af erfaringer for at arbejde for en fælles retlig udvikling i Norden, når dette er formålstjenligt. Herudover lægges der vægt på nedbrydning af grænsehindringer og på at forhindre at nye opstår.

Målsætningen omfatter også samarbejde om spørgsmål som angår udvikling af juridisk rådgivning og offentlig retshjælp, anvendelse af elektronisk overvågning som retsfølge samt forekomst og former for korruption, herunder bestikkelse (mutor) i de nordiske lande.

Det er endvidere en målsætning at bidrage aktivt til fællesnordisk initiativ om demokrati, inkludering og sikkerhed.

Ministerrådet har i 2014 vedtaget et nyt Samarbejdsprogram for Justitssektoren.

Ministerrådet har besluttet at være en aktiv deltager i en fælles nordisk indsats om bekæmpelse af menneskehandel og har til det formål afsat 800.000 DKK til delfinansiering af et tværgående program om bekæmpelse af menneskehandel. Beløbet er det hidtil største som Justitssektoren har afsat til en indsats.

Ministerrådet har drøftet politiske problemstillinger om strafferetligt ansvar for juridiske personer, revision af domstolssystemer, mulighederne for overførelse af dømte til afsoning $i$ et andet land end hjemlandet, voldsofres retsstilling samt ungdomskriminalitet.

De nordiske og de baltiske justitsministre har drøftet politiske problemstillinger om emner af fælles interessem, og bedt. Nordic Baltic Contact Group gennemføre aktiviteter om bl.a. judicial examination of child victims and witnesses og reforms in the judiciary.

Embedsmandskomiteen for lovsamarbejde har ydet økonomisk støtte til bl.a. et projekt om "Restatement of Nordic Contract Law”. Formålet med projektet er at give udenlandske virksomheder og beslutningstagere bedre muligheder for at få et klart indtryk af, hvilke kontraktlige regler der gælder i de nordiske lande, og at bidrage til, at den nordiske retstradition kan påvirke den igangværende internationalisering af kontraktretten. 
11-7110 Projektmedel - Lagstiftning

Projektmidler

\begin{tabular}{|l|c|c|c|c|c|} 
Valuta & Budget 2016 & Budget 2015 & Budget 2014 & Disp./bud. 14 & Budget disp. af \\
\hline DKK & 1.382 .000 & 1.382 .000 & 1.390 .000 & $85 \%$ & MR-LAG/NÄL
\end{tabular}

Formål

Formålet med budgetposten er at understøtte Justitssektorens realisering af fastsatte formål og strategiområder. Budgetposten kan anvendes dels til iværksættelse og gennemførelse af initiativer direkte af Ministerrådet, dels til økonomiske tilskud til modtagne projektansøgninger. 


\section{Nordisk Ministerråds budget for virksomhedsåret 2016}

\section{Budgettets indtægter og landenes indbetalinger}

Nordisk Ministerråds budget finansieres i første række af direkte bidrag fra landene. Som udgangspunkt indbetaler landene et beløb svarende til aktivitetsrammen fratrukket afgift på løn, nettorenteindtægter og øvrige indtægter, som det er vist i nedenstående tabel. Landenes indbetalinger sker i henhold til en særskilt fordelingsnøgle, som er beregnet på basis af det respektive lands andel af den samlede bruttonationalindtægt i faktorpriser i Norden for de to seneste kendte år, som i budgettet for 2016 er 2012 og 2013.

\begin{tabular}{|c|c|c|c|c|c|c|c|c|}
\hline $\begin{array}{l}\text { INDT } \not \text { ETER } \\
\text { TDKK (løbende priser) }\end{array}$ & $\begin{array}{r}\text { Budget } \\
2013\end{array}$ & $\begin{array}{r}\text { Ford. } \\
\text { nøgle } \\
2013\end{array}$ & $\begin{array}{r}\text { Budget } \\
2014\end{array}$ & $\begin{array}{r}\text { Ford. } \\
\text { nøgle } \\
2014\end{array}$ & $\begin{array}{r}\text { Budget } \\
2015\end{array}$ & $\begin{array}{r}\text { Ford. } \\
\text { nøgle } \\
2015\end{array}$ & $\begin{array}{r}\text { Budget } \\
2016\end{array}$ & $\begin{array}{r}\text { Ford. } \\
\text { nøgle } \\
2016\end{array}$ \\
\hline Afgift på løn & 11.000 & & 12.000 & & 13.000 & & 12.500 & \\
\hline Øvrige indtægter (f.eks. renter) & 1.200 & & 1.100 & & 600 & & 400 & \\
\hline Landenes bidrag & 974.526 & & 942.115 & & 922.510 & & 909.564 & \\
\hline - Danmark & 217.319 & $22,3 \%$ & 197.844 & $21,0 \%$ & 184.502 & $20,0 \%$ & 176.455 & $19,4 \%$ \\
\hline - Finland & 169.568 & $17,4 \%$ & 153.565 & $16,3 \%$ & 142.989 & $15,5 \%$ & 142.802 & $15,7 \%$ \\
\hline - Island & 6.822 & $0,7 \%$ & 6.595 & $0,7 \%$ & 6.458 & $0,7 \%$ & 7.277 & $0,8 \%$ \\
\hline - Norge & 285.536 & $29,3 \%$ & 288.287 & $30,6 \%$ & 290.591 & $31,5 \%$ & 293.789 & $32,3 \%$ \\
\hline - Sverige & 295.281 & $30,3 \%$ & 295.824 & $31,4 \%$ & 297.971 & $32,3 \%$ & 289.241 & $31,8 \%$ \\
\hline Sum : & 986.726 & $100 \%$ & 955.215 & $100 \%$ & 936.110 & $100 \%$ & 922.464 & $100 \%$ \\
\hline
\end{tabular}

\section{Betalingsordningen for højere uddannelser}

Det er besluttet i Overenskomsten om adgang til videregående uddannelse, at konsekvenserne af betalingsordningen for de nordiske lande skal reguleres over Ministerrådets budget, og påvirker derved landenes bidrag til det nordiske budget. Betalingsordningen gælder Danmark, Finland, Norge og Sverige. Island, Grønland, Færøerne og Åland står udenfor betalingsordningen. Der tages hensyn til landenes gensidige betalinger i landenes bidrag og aftalen påvirker alene den interne fordeling af bidragene mellem landene (Danmark, Finland, Norge og Sverige). Det er i 2012 besluttet at forlænge overenskomsten til udgangen af 2015. Processen at forlænge overenskomsten fra og med 2016 er i gang.

Af overenskomsten fremgår det, at der skal ske betaling for 75 \% af det antal studerende, som modtager studiestøtte fra det land hvor den studerende er bosat efter gældende regler i det land, og som er indskrevet på en højere uddannelse i et andet land, som falder ind under Artikel $1 \mathrm{i}$ overenskomsten.

Forskningsuddannelser samt studerende på uspecificeret højere uddannelse medregnes ikke i beregningsgrundlaget. Den årlige erstatning pr. studerende er 30.280 DKK i 2016.

Ministerrådet modtager statistik fra de nordiske studiestøttemyndigheder, som ligger til grund for beregningen af antal studerende mellem de nordiske lande, der indgår i ordningen. 
Betalingsordning, højere uddannelse TDKK

\begin{tabular}{lrrrr}
\hline & Budget & Budget & Budget & Budget \\
& $\mathbf{2 0 1 3}$ & $\mathbf{2 0 1 4}$ & $\mathbf{2 0 1 5}$ & $\mathbf{2 0 1 6}$ \\
\hline Danmark & -76.830 & -89.078 & -85.457 & -83.278 \\
Finland & 17.335 & 19.777 & 24.387 & 29.137 \\
Island & 0 & 0 & 0 & 0 \\
Norge & 46.917 & 58.343 & 59.456 & 57.479 \\
Sverige & 12.578 & 10.958 & 1.614 & -3.338 \\
\hline Sum: & 0 & 0 & 0 & 0 \\
\hline
\end{tabular}

\section{Indbetalinger fra landene}

Landenes indbetalinger til Nordisk Ministerråd er følgende efter korrektion for betalingsordningen for højere uddannelse:

Indbetalinger efter betalingsordning og reduktion i grundkapital, løbende priser TDKK

\begin{tabular}{lrrrr}
\hline & Budget 2013 & Budget 2014 & Budget 2015 & $\begin{array}{r}\text { Budget } \\
\text { 2016 }\end{array}$ \\
\hline Danmark & 140.489 & 108.766 & 99.045 & 93.178 \\
Finland & 186.903 & 173.342 & 167.376 & 171.938 \\
Island & 6.822 & 6.595 & 6.458 & 7.277 \\
Norge & 332.453 & 346.630 & 350.047 & 351.268 \\
Sverige & 307.859 & 306.782 & 299.585 & 285.903 \\
\hline Sum: & 974.526 & 942.115 & 922.510 & 909.564 \\
\hline
\end{tabular}

\section{Landenes prognosticerede indbetalinger i national valuta}

Som et resultat af budgetmoderniseringsarbejdet besluttede MR-SAM i februar 2007, at der i budgetforslaget skal præsenteres en prognose for landenes indbetalinger til Nordisk Ministerråd i budgetårets priser (2016-priser). Beregningen foregår i to tempi:

1) Ud fra fordelingen på budgetpostkategorier kan den pris- og valutaregulerede udgiftsramme i 2016 beregnes. Denne beregning er foretaget i nedenstående tabel. Prisfaktorerne der er benyttet, er de nationale finansministeriers forventninger til udviklingen i forbrugerprisindekset i $2016 \mathrm{og}$ valutakurserne er de officielle månedsgennemsnitskurser fra den danske nationalbank og for den islanske krones vedkommende den islandske nationalbank i perioden oktober 2014 til og med maj 2015.

Prisopregning fordelt på kategorier og den totale udgiftsrammer i 2016 priser

\begin{tabular}{lrrrr}
\hline & $\begin{array}{r}\text { Bevilling } \\
\text { 2014 priser }\end{array}$ & Valutakurser & Prisfaktorer & $\begin{array}{r}\text { Udgiftsramme, } \\
\text { TDKK }\end{array}$ \\
\hline Projektmidler & 542.438 & - & $1,6 \%$ & 551.117 \\
Institutioner i: & & & & \\
Danmark & 112.137 & 100 & $1,5 \%$ & 113.819 \\
Finland & 2.344 & 745 & $1,4 \%$ & 17.708 \\
Island & 181.367 & 5 & $3,0 \%$ & 9.154 \\
Norge & 214.837 & 87 & $2,25 \%$ & 191.113 \\
Sverige & 68.288 & 80 & $0,94 \%$ & 55.144 \\
\hline Sum: & & & & 938.055 \\
\hline
\end{tabular}


2) Når den totale aktivitetsramme i 2016 er kendt kan landenes indbetalinger beregnes ved at fordele finansieringsbyrden efter fordelingsnøglen og korrigere for betalingsordningen for højere uddannelse.

Landenes indbetalinger til Nordisk Ministerråd 2016, pris- og valutaomregnede

\begin{tabular}{|c|c|c|c|c|}
\hline TDKK & $\begin{array}{l}\text { Fordelings- } \\
\text { nøgle }\end{array}$ & Indtægter & Betalingsordning & Indbetaling \\
\hline Afgift på løn & & 12.500 & & \\
\hline Renteindtægter & & 400 & & \\
\hline Landenes bidrag & & 925.155 & & \\
\hline Danmark & $19,4 \%$ & 179.480 & -83.278 & 96.203 \\
\hline Finland & $15,7 \%$ & 145.249 & 29.137 & 174.386 \\
\hline Island & $0,8 \%$ & 7.401 & 0 & 7.401 \\
\hline Norge & $32,3 \%$ & 298.825 & 57.479 & 356.304 \\
\hline Sverige & $31,8 \%$ & 294.199 & -3.338 & 290.861 \\
\hline Sum: & $100,0 \%$ & 938.055 & 0 & 925.155 \\
\hline
\end{tabular}

Nedenfor vises med udgangspunkt i den prognosticerede ramme i 2016-prisniveau og de viste valutakurser landenes prognosticerede indbetalinger til Nordisk Ministerråd i tusinder af det enkelte lands valuta (beløb incl. betalingsordningen).

\begin{tabular}{lrl}
\hline Budget 2016 - Landenes prognosticerede bidrag i national valuta \\
\hline Danmark & 96.203 & DKK \\
Finland & 23.408 & EUR \\
Island & 151.046 & ISK \\
Norge & 409.545 & NOK \\
Sverige & 363.576 & SEK \\
\hline
\end{tabular}




\section{Historisk udvikling i Nordisk Ministerråds budget og likviditet}

\section{Besparelse i det nordiske budget 2014 - 2016}

Budgetrammen for Nordisk Ministerråds budget er beskåret i år ligesom de sidste par år, i overensstemmelse med samarbejdsministrenes beslutning derom. Budgetrammen i 2016 er $1 \%$ lavere i forhold til rammen i 2015 som svarer til en nedskæring på 9 MDKK. I 2014 var der en 5 \% besparelse i forhold til budget 2013 men det svarede til 49 MDKK nedskæring i rammen og i 2015 var der $2 \%$ nedskæring, som svarer til 19 MDKK.

\section{Fordeling af besparelserne på sektorer*:}

\begin{tabular}{|c|c|c|c|c|c|c|}
\hline Besparelser i TDKK & \begin{tabular}{|l}
2014 i henhold \\
til budget 2013 \\
\end{tabular} & $\begin{array}{r}\% \text { af sekt. } \\
\text { størrelse }\end{array}$ & $\begin{array}{l}2015 \text { i henhold } \\
\text { til budget } 2014 \\
\end{array}$ & $\begin{array}{r}\% \text { af sekt. } \\
\text { størrelse }\end{array}$ & $\begin{array}{l}2016 \text { i henhold } \\
\text { til budget } 2014\end{array}$ & $\begin{array}{r}\% \text { af sekt. } \\
\text { størrelse }\end{array}$ \\
\hline Samarbejdsministrene & -20.734 & $-7 \%$ & -5.138 & $-2 \%$ & -6.523 & $-3 \%$ \\
\hline Uddannelse og forskning & -9.201 & $-4 \%$ & -4.768 & $-2 \%$ & -2.795 & $-1 \%$ \\
\hline Social- og Helsepolitik & -1.772 & $-4 \%$ & -806 & $-2 \%$ & 0 & $0 \%$ \\
\hline Kulturpolitik & -8.203 & $-5 \%$ & -3.358 & $-2 \%$ & 0 & $0 \%$ \\
\hline Fiskeri og havbrug, Jordbrug, Levnedsmidler og Skovbrug & -1.715 & $-4 \%$ & -822 & $-2 \%$ & 0 & $0 \%$ \\
\hline Ligestilling & -339 & $-4 \%$ & -178 & $-2 \%$ & 0 & $0 \%$ \\
\hline Närings-, Energi- og Regionalpolitik & -5.026 & $-4 \%$ & -2.809 & $-2 \%$ & 0 & $0 \%$ \\
\hline Miljø & -1.696 & $-4 \%$ & -888 & $-2 \%$ & 0 & $0 \%$ \\
\hline Arbejdsmarkedspolitik & -535 & $-4 \%$ & -274 & $-2 \%$ & 0 & $0 \%$ \\
\hline Ekonomi og Finanspolitik & -65 & $-4 \%$ & -36 & $-2 \%$ & 0 & $0 \%$ \\
\hline \multirow[t]{2}{*}{ Lagstiftning } & -50 & $-4 \%$ & -28 & $-2 \%$ & 0 & $0 \%$ \\
\hline & -49.336 & $-5 \%$ & -19.105 & $-2 \%$ & -9.318 & $-1 \%$ \\
\hline
\end{tabular}

*Besparelser pr. budgetår er sammenlignet med budgettet året inden, i dets års prisniveau.

\section{Udviklingen i udisponerede midler 2012 - 2014}

Udisponerede midler er defineret som midler, hvor der ikke er foretaget en beslutning om anvendelse til et bestemt formål. Udisponerede midler kan alene forekomme under budgetposter med projektmidler og programlignende aktiviteter, idet ministerrådet på institutioner og organisationsbidrag udbetaler alle midler til eksterne parter, som har dispositionsretten over midlerne, og derfor er disse midler i Ministerrådets budget altid pr. definition 100 \% disponeret. Projektmidler og programlignende aktiviteter udgjorde totalt ca. 55 \% af ministerrådets budget i 2014.

I forbindelse med en tidligere modernisering af budgettet og vedtagelse af Generalsekretærens forslagskatalog i 2007, besluttede MR-SAM at indføre en 20 pct. regel, kombineret med et minimumsbeløb på 200.000 DKK, som betød, at højst $20 \%$ af årets budget på en budgetpost kunne videreføres til næste år; dog kunne man altid videreføre 200.000 DKK. Denne regel er med moderniseringen af budgettet i 2014 ændret til en 15 \% regel, med et minimumsbeløb på 150.000 DKK. ${ }^{1}$

Samarbejdsministrene besluttede i maj måned 2009, at fra og med virksomhedsår 2009 skal midler, som falder for 15 pct. reglen, tilbageføres til landene. Beslutningen er taget på baggrund af, at budgetrammen i 2008 blev udvidet med et engangsløft på 35 MDKK til finansiering af globaliseringsinitiativerne.

På budgetpostniveau under hvert ministerråd viser rubrikken ”Disp./Bud 14”, hvor meget der er disponeret i budgetåret 2014 ud af 14-budgettet i procent. I bilag 2 vises en oversigt over status på regnskabstal på alle budgetposter pr. 27. maj 2015.

\footnotetext{
${ }^{1}$ Minimumsgrænsen er indført af hensyn til de små projektbudgetposter, som en procentordning alene vil ramme uforholdsmæssigt hårdt.
} 
Følgende er grafisk vist de udisponerede midler i 2012 - 2014 samt en oversigt over fordelingen af de udisponerede midler på ministerråd i TDKK og i procent af sektorens samlede ramme.

Som det ses af grafen og den efterfølgende tabel, minskede de udisponerede midler fra 2013 til 2014 med 15,6 MDKK.

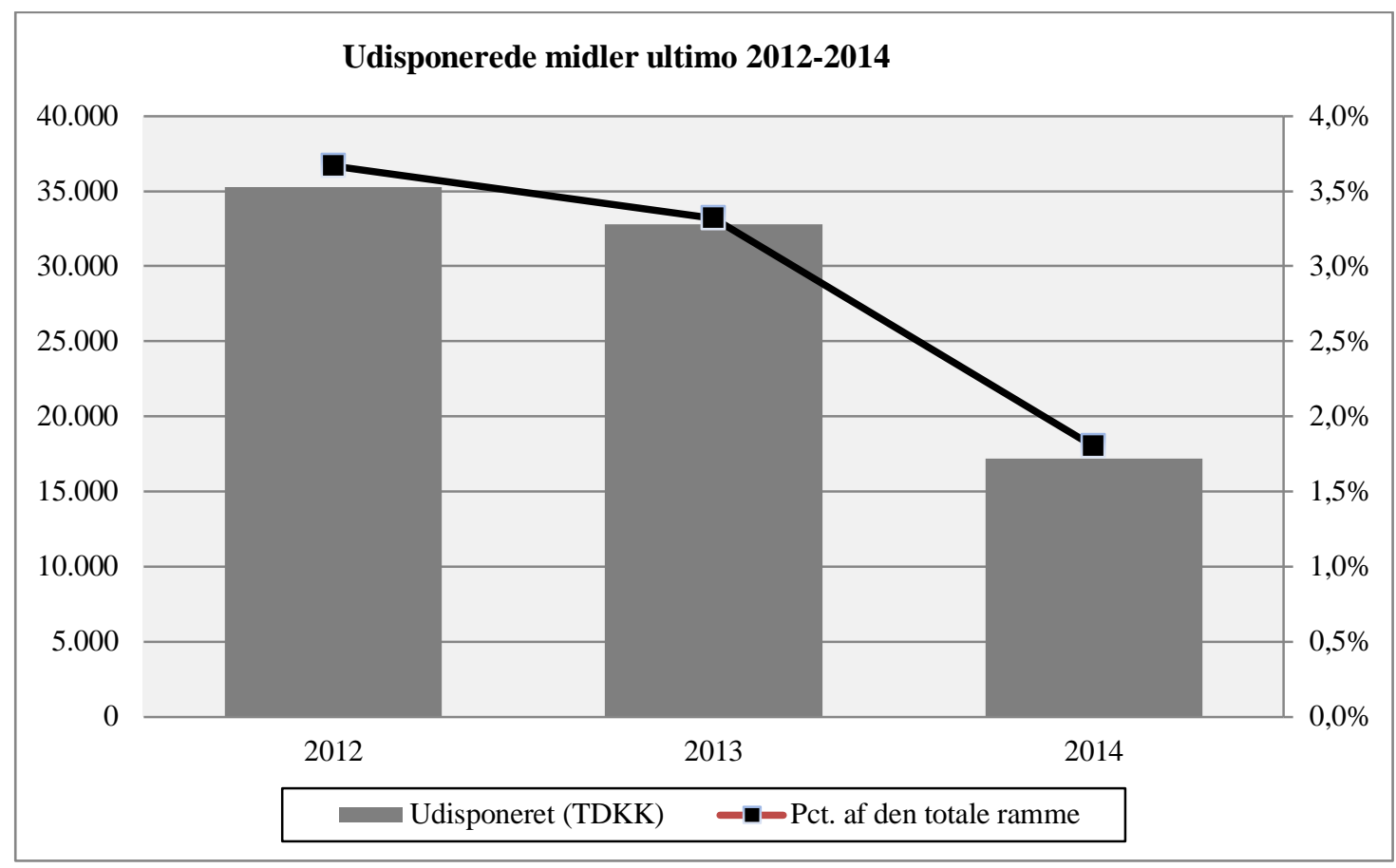

Udisponerede midler ultimo 2012-2014

\begin{tabular}{|c|c|c|c|c|c|c|c|}
\hline S ektor (TDKK) & 2012 & $\begin{array}{r}\% \text { af sekt. } \\
\text { størrelse }\end{array}$ & 2013 & $\begin{array}{c}\% \text { af sekt. } \\
\text { størrelse }\end{array}$ & 2014 & $\begin{array}{r}\% \text { af sekt. } \\
\text { størrelse }\end{array}$ & $\begin{array}{r}\text { Beskåret jf. } \\
15 \text { \% regl. }\end{array}$ \\
\hline Prioriteringsbudgettet & - & & 3.242 & $4 \%$ & 3.939 & $5 \%$ & 2.318 \\
\hline Internationalt samarbejde & 6.969 & $7 \%$ & 8.474 & $9 \%$ & 2.618 & $3 \%$ & 105 \\
\hline Uddannelse og forskning & 10.612 & $5 \%$ & 11.064 & $5 \%$ & 1.970 & $1 \%$ & 256 \\
\hline Social- og Helsep olitik & 361 & $1 \%$ & 897 & $2 \%$ & 865 & $2 \%$ & 37 \\
\hline MR-FJLS & 623 & $2 \%$ & 856 & $2 \%$ & 1.714 & $4 \%$ & 103 \\
\hline Kulturpolitik & 1.548 & $1 \%$ & 788 & $0 \%$ & 593 & $0 \%$ & 1 \\
\hline Ligestilling & 465 & $5 \%$ & 1.045 & $11 \%$ & 28 & $0 \%$ & 0 \\
\hline MR-NER & 1.450 & $1 \%$ & 781 & $1 \%$ & 2.347 & $2 \%$ & 0 \\
\hline Miljø & 672 & $2 \%$ & 716 & $2 \%$ & 629 & $1 \%$ & 0 \\
\hline Arbejdslivspolitik & 1.028 & $8 \%$ & 1.103 & $8 \%$ & 883 & $6 \%$ & 84 \\
\hline Ekonomi og Finanspolitik & 165 & $9 \%$ & 54 & $3 \%$ & 67 & $4 \%$ & 0 \\
\hline Lagstiftning & 223 & $16 \%$ & 188 & $13 \%$ & 209 & $15 \%$ & 45 \\
\hline Øvrig virksomhet & 11.128 & $6 \%$ & 3.564 & $3 \%$ & 1.342 & $1 \%$ & 1.580 \\
\hline SUM & 35.244 & $3,7 \%$ & 32.772 & $3,3 \%$ & 17.204 & $1,8 \%$ & 4.529 \\
\hline
\end{tabular}




\section{Nordisk Ministerråds institutioner ikke-forbrugte midler}

Midler til Nordisk Ministerråds institutioner i Ministerrådets budget er altid pr. definition 100 \% disponerede. De eksterne parter (institutionerne) har dispositionsretten over midlerne. De midler som institutionerne ikke har foretaget en beslutning om anvendelse til, bliver ved årets udgang den enkelte institutions egenkapital. Institutionens egenkapital skal sikre, at institutionen er solvent og tillige har den nødvendige likviditet til at dække løbende udgifter i institutionen.

Nedenstående graf viser størrelsen af egenkapitalen som andel af institutionernes samlede indtægter åren 2013 og 2014. Tabelen viser nøgletal for institutionernes økonomi i 2014 - med forbehold for regnskabernes endelige godkendelse.

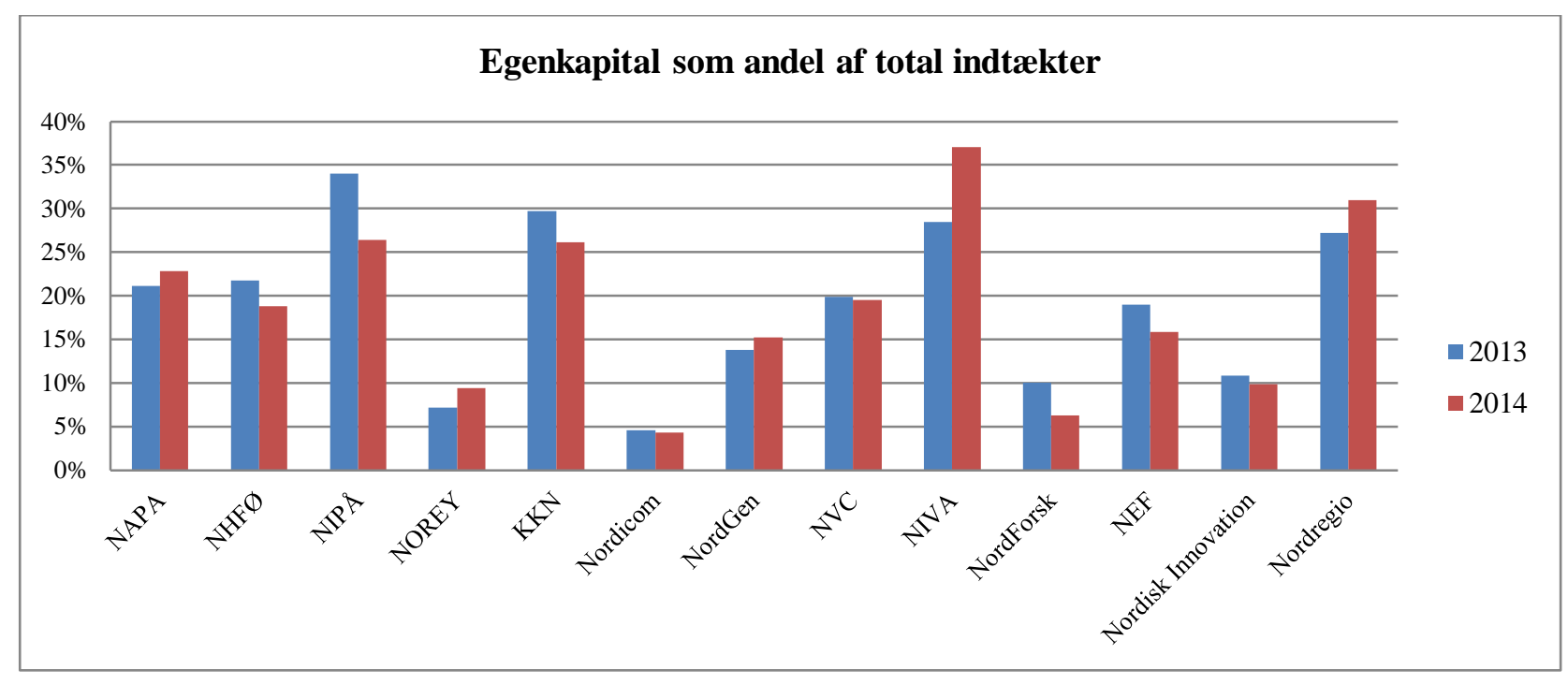

Nordiske institutioner - Regnskab 2014 (Omregnet 1.000 DKK)

\begin{tabular}{|c|c|c|c|c|c|c|c|c|c|c|}
\hline \multirow[b]{2}{*}{ Institution } & \multicolumn{4}{|c|}{ Indtægter } & \multicolumn{3}{|c|}{ Udgifter } & \multirow[b]{2}{*}{$\begin{array}{r}\text { Årets } \\
\text { resultat }\end{array}$} & \multirow[b]{2}{*}{$\begin{array}{r}\text { Likvide } \\
\text { beholdning }\end{array}$} & \multirow{2}{*}{$\begin{array}{r}\text { Overførte } \\
\text { midler / } \\
\text { Egen- } \\
\text { kapital }\end{array}$} \\
\hline & I alt & $\begin{array}{r}\text { Fra NMR } \\
\text { (basis- } \\
\text { bevilling) }\end{array}$ & $\begin{array}{r}\text { Fra NMR } \\
\text { (projekt- } \\
\text { bevilling) }\end{array}$ & NMR \% & I alt & $\begin{array}{l}\text { Admini- } \\
\text { stration }\end{array}$ & $\%$ adm. & & & \\
\hline NAPA & 6.988 & 6.247 & - & $89 \%$ & 7.007 & 1.477 & $21,1 \%$ & -18 & 2.781 & 1.593 \\
\hline NHFØ & 20.761 & 13.330 & 743 & $68 \%$ & 21.022 & 2.810 & $13,4 \%$ & -261 & 5.007 & 3.899 \\
\hline NIPÅ & 3.783 & 2.895 & - & $77 \%$ & 4.502 & 1.077 & $23,9 \%$ & -720 & 973 & 997 \\
\hline NOREY & 12.868 & 8.412 & 3.006 & $89 \%$ & 12.812 & 2.432 & $19,0 \%$ & 55 & 696 & 1.205 \\
\hline KKN & 13.233 & 10.883 & 1.440 & $93 \%$ & 13.771 & 1.119 & $8,1 \%$ & -539 & 3.447 & 3.454 \\
\hline Nordicom & 12.967 & 3.144 & 592 & $29 \%$ & 12.909 & 1.324 & $10,3 \%$ & 58 & 913 & 557 \\
\hline NordGen & 29.839 & 20.810 & 1.565 & $75 \%$ & 29.626 & 4.888 & $16,5 \%$ & 213 & 19.395 & 4.548 \\
\hline NVC & 33.124 & 21.142 & 7.218 & $86 \%$ & 33.720 & 5.394 & $16,0 \%$ & -597 & 11.641 & 6.466 \\
\hline NHV & 44.122 & - & 14 & $0 \%$ & 41.298 & 5.588 & $13,5 \%$ & 2.824 & 30.139 & 7.587 \\
\hline NIVA & 4.593 & 3.314 & 71 & $74 \%$ & 4.073 & 515 & $12,6 \%$ & 520 & 2.066 & 1.701 \\
\hline NordForsk & 260.666 & 121.382 & 2.397 & $47 \%$ & 265.847 & 5.065 & $1,9 \%$ & -5.180 & 542.030 & 16.261 \\
\hline NEF & 53.619 & 6.971 & 10.922 & $33 \%$ & 54.820 & 5.519 & $10,1 \%$ & -1.202 & 62.407 & 8.505 \\
\hline $\begin{array}{l}\text { Nordisk } \\
\text { Innovation }\end{array}$ & 128.327 & 79.096 & 9.916 & $69 \%$ & 130.138 & 5.765 & $4,4 \%$ & -1.811 & 128.721 & 12.622 \\
\hline Nordregio & 30.052 & 11.701 & 5.837 & $58 \%$ & 28.279 & 4.907 & $17,4 \%$ & 1.773 & 17.781 & 9.318 \\
\hline I alt & 654.943 & 309.326 & 43.719 & & 659.826 & 47.880 & & -4.883 & 827.996 & 78.713 \\
\hline
\end{tabular}


Budgettets udvikling i perioden 2005 - 2016

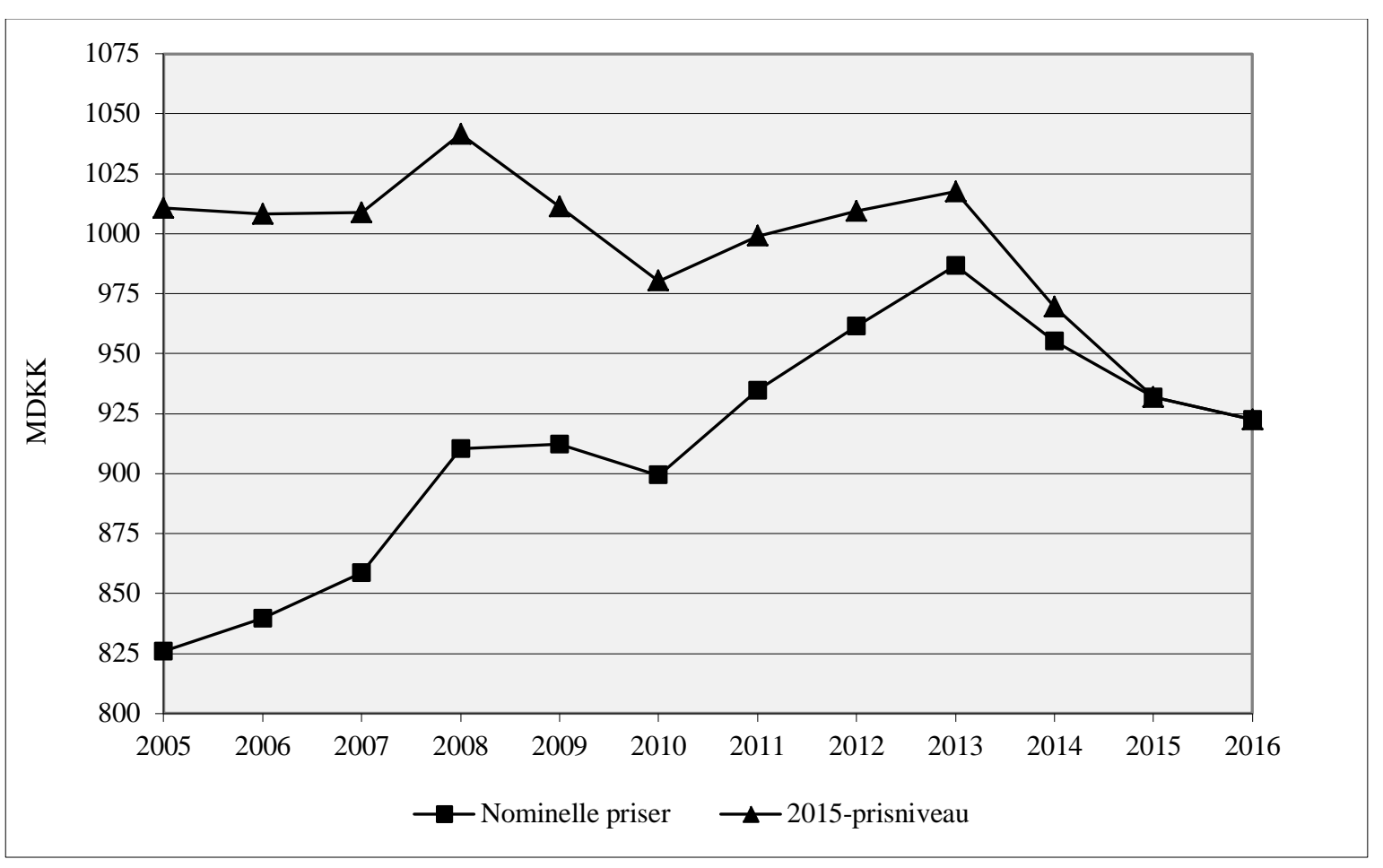

MR-SAM har for 2016 vedtaget en ramme der indeholder $1 \%$ nedskæring (- 9 MDKK) i budgetrammen i forhold til rammen 2015. I 2015 var der $2 \%$ nedskæring (-19 MDKK) i budgetrammen i forhold til 2014 og i 2014 var der 5 \% besparelse forhold til 2013 (-49 MDKK).

Niveauskiftet i 2008 skal ses på baggrund af beslutningen i forbindelse med budget 2008 om at finansiere en del af globaliseringssatsninger på 60 MDKK i 2008, som statsministrene lancerede i Punkaharju i Finland i juni 2007, med en forøgelse af aktivitetsrammen på 35 MDKK.

Når budgettet i faste priser i 2010 falder i forhold til 2009, og fortsat i 2011 ligger under niveauet for 2009, skyldes det, de udsving der har været i valutakurserne. I dette tilfælde skyldes det konkret det store fald i norske og svenske kroners værdi fra sidste halvdel af 2008 til midten af 2009 i forhold til danske kroner. Stigningen fra 2011 til 2012 og forsat til 2013 skyldes på samme måde stigningen i norske og svenske kroner i forhold til danske kroner. Den relativt store fald i faste priser i 2015 i forhold til 2014 skyldes, foruden en 2 \% nedskæring i budgettet, fald i norske og svenske kroners værdi i forhold til danske kroner. 


\section{Likviditetens udvikling}

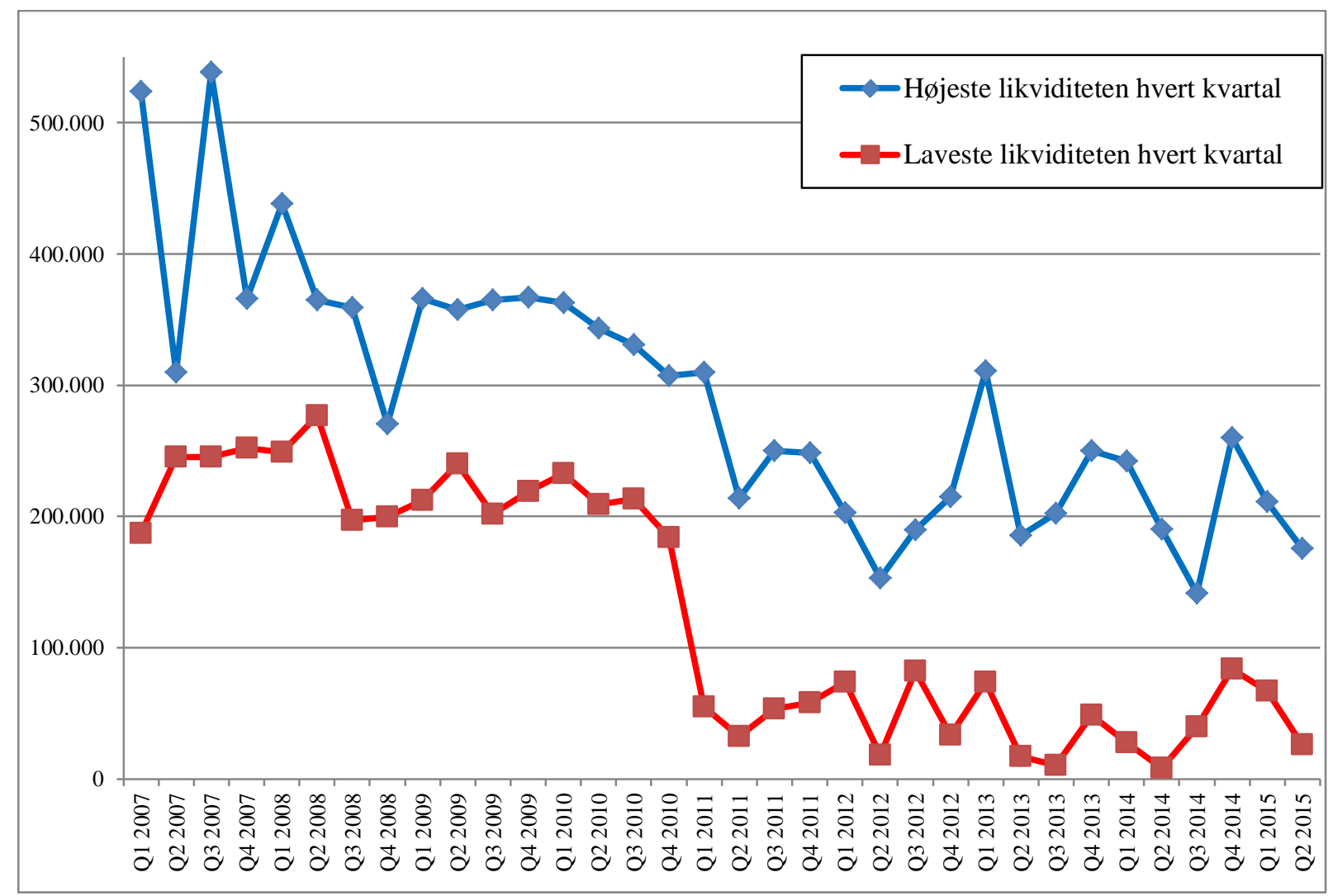

Denne graf viser to serier, den ene viser den samlede likviditets højeste punkt hvert kvartal og den anden den laveste. Likviditetsbeholdingen indeholder Ministerrådets totale likviditet hvor likviditeten i anden valute end dansk er beregnet til danske kroner.

Fra og med budgetåret 2008 er landene begyndt at indbetale 4 gange årligt mod tidligere 2 gange, som betyder et ændret mønster i Ministerrådets likviditetsbeholdning. Fra og med midten af året 2014 er landene begyndt at indbetale 8 gange om året, hvor 4 indbetalinger er i DKK og 4 er i landenes valuta.

MR-SAM besluttede i november 2010 at forskyde landenes indbetalinger med to måneder. Effekten heraf er, som ses af figuren, at ministerrådets samlede likviditet er reduceret betydeligt allerede i 2011 og på visse tidspunkter derefter er tæt på 0 .

Ministerrådets likviditetbeholding i danske kroner har været særskilt alvorlig i indeværende år, hvor den i nogle perioder har været negativ og NMRS har bl.a. måtte udskyde udbetalinger. Denne situation kan bedre ses på følgende graf, der viser likviditeten udelukkende i danske kroner i 2015. Landene indbetaler en del af sin bevilling til ministerrådet i egen valuta. Den del af indbetalingerne er udelukkende brugt til dækkning af Ministerrådets udbetalinger af basisbevillinger til institutionerne i de respektive lande. Derfor er likviditeten i danske kroner vigtig, eftersom den skal bruges til at finansiere alle projekter, programmer og organisationgsbidrag i Ministerrådets regi, samt finansiere sekretariatet. 


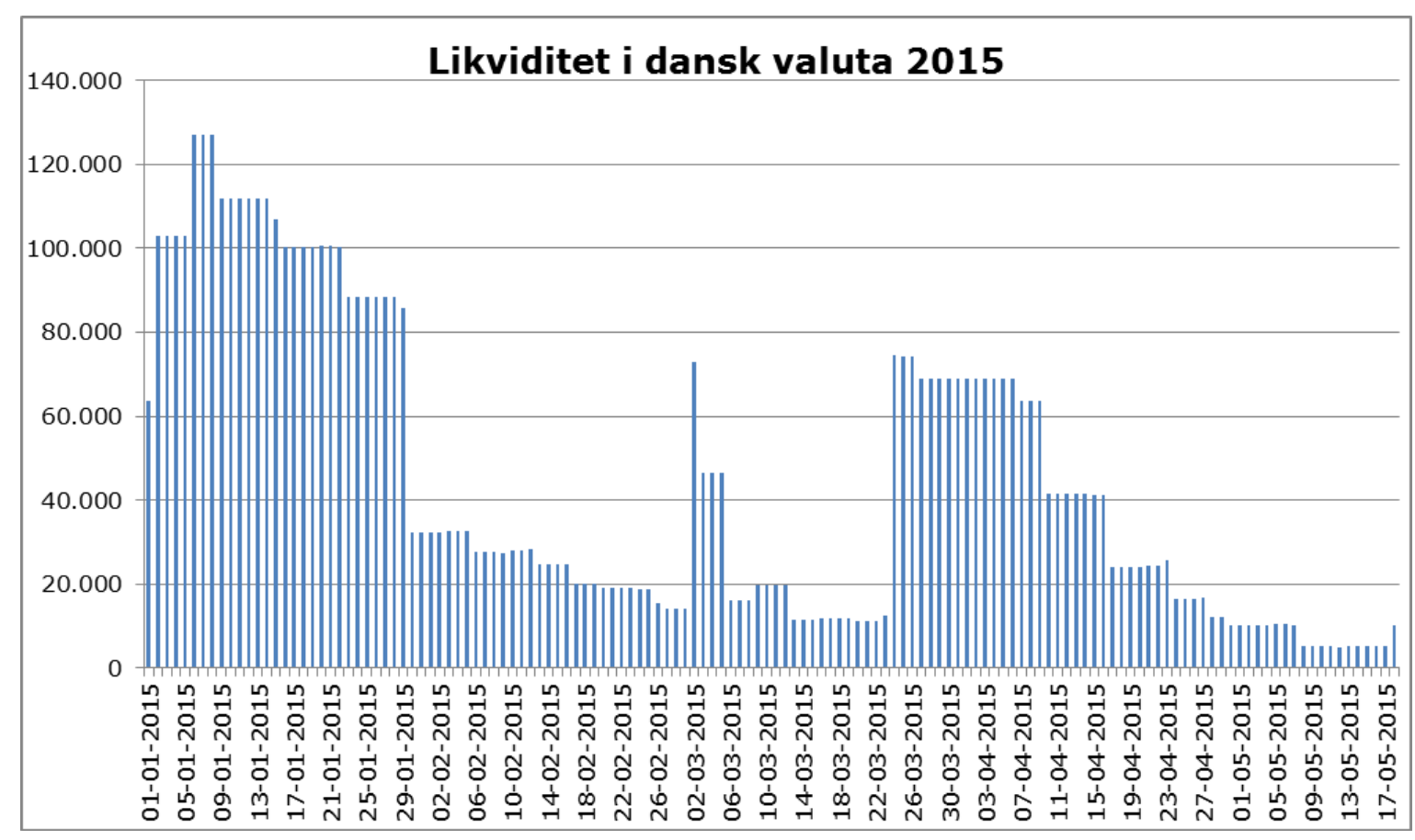




\section{Bilag 1 - Budgettet konverteret til EURO}

\begin{tabular}{|c|c|c|c|c|c|}
\hline & Samarbejdsministrene & Budget & Budget & Diffe & ence \\
\hline & & 2016 & 2015 & $+/-$ & $\%$ \\
\hline Sum Pr & oriteringsbudgettet (TDKK) & 9.970 & 9.970 & $\mathbf{0}$ & $0,0 \%$ \\
\hline & Formandskapspuljen, Finland & 2.011 & & & \\
\hline & Formandskapspuljen, Danmark & 2.011 & 2.041 & -30 & $-4,4 \%$ \\
\hline $1-8008$ & Vækst & 536 & 544 & -8 & $-1,5 \%$ \\
\hline $1-8009$ & Velfærd & 536 & 544 & -8 & $-1,5 \%$ \\
\hline $1-8010$ & Værdier & 603 & 612 & -9 & $-1,5 \%$ \\
\hline $1-8011$ & Det blå Arktis & 335 & 340 & -5 & $-1,5 \%$ \\
\hline & Formandskapspuljen, Island & 2.011 & 2.041 & -30 & $-4,4 \%$ \\
\hline $1-8005$ & Den nordiska spellistan & 268 & 272 & -4 & $-1,5 \%$ \\
\hline $1-8006$ & Välfärdsvakten & 402 & 408 & -6 & $-1,5 \%$ \\
\hline $1-8007$ & Bioekonomi-initativet & 1.340 & 1.361 & -20 & $-1,5 \%$ \\
\hline & Formandskapspuljen, Sverige & 0 & 2.041 & -2.041 & $-100,0 \%$ \\
\hline $1-8001$ & NordMin & $\overline{0}$ & 1.361 & -1.361 & $-100,0 \%$ \\
\hline $1-8003$ & $\begin{array}{l}\text { Förbättrade emissionsinventeringar av kortlivade } \\
\text { klimatpåvekande luftföreningar }\end{array}$ & 0 & 272 & -272 & $-100,0 \%$ \\
\hline 1-8004 & Lärande på arbetsplats & 0 & 408 & -408 & $-100,0 \%$ \\
\hline & Prioriteringspuljen & 3.938 & 3.847 & 91 & $2,4 \%$ \\
\hline $1-8111$ & Uddannelse og forskning inden for grøn vækst & $\overline{0}$ & 544 & -544 & $-100,0 \%$ \\
\hline $1-8112$ & Elmarknaden & 0 & 136 & -136 & $-100,0 \%$ \\
\hline $1-8113$ & $\begin{array}{l}\text { Grønne tekniske normer og standarder - Norden } \\
\text { som standardmaker }\end{array}$ & 0 & 354 & -354 & $-100,0 \%$ \\
\hline $1-8115$ & Utveckla tekniker och metoder för avfallshantering & 0 & 612 & -612 & $-100,0 \%$ \\
\hline $1-8116$ & $\begin{array}{l}\text { Främja integrationen av miljö och klima i } \\
\text { utvecklingssamarbetet }\end{array}$ & 0 & 68 & -68 & $-100,0 \%$ \\
\hline $1-8118$ & Särskilda prioriteringer Grön tillväxt & 0 & 54 & -54 & $-100,0 \%$ \\
\hline $1-8210$ & Hållbar nordisk välfärd & 0 & 1.497 & -1.497 & $-100,0 \%$ \\
\hline $1-8212$ & Välfärd och kost & 0 & 105 & -105 & $-100,0 \%$ \\
\hline $1-8410$ & Politiska prioriteringar & 804 & 476 & 328 & - \\
\hline $1-8411$ & Politiske initiativer i nærområderne & 452 & 0 & 452 & - \\
\hline $1-8420$ & Profilering og positionering & 1.340 & 0 & 1.340 & - \\
\hline $1-8510$ & Nye tværgående initiativer & 1.340 & 0 & 1.340 & - \\
\hline Opdelt & å kategorier & 9.970 & 9.970 & $100 \%$ & $100 \%$ \\
\hline & Projektmidler & 2.597 & 735 & $26,0 \%$ & $7,4 \%$ \\
\hline & Programlignende aktiviteter & 5.362 & 9.235 & $53,8 \%$ & $92,6 \%$ \\
\hline & Formandskap FI, ikke endnu opdelt på kategorier & 2.011 & & $20,2 \%$ & \\
\hline
\end{tabular}

\section{Samarbejdsministrene}

\begin{tabular}{rrrr} 
Budget & Budget & \multicolumn{2}{c}{ Difference } \\
$\mathbf{2 0 1 6}$ & $\mathbf{2 0 1 5}$ & \multicolumn{1}{c}{+ /- } & \multicolumn{1}{c}{$\%$} \\
\hline $\mathbf{9 . 0 8 8}$ & $\mathbf{9 . 9 6 2}$ & $\mathbf{- 8 7 4}$ & $\mathbf{- 8 , 8 \%}$ \\
& 0 & & \\
\hline 3.633 & 3.703 & -70 & $-1,9 \%$ \\
332 & 332 & 0 & $0,0 \%$ \\
848 & 848 & 0 & $0,0 \%$ \\
0 & 1.273 & -1.273 & $-100,0 \%$ \\
2.055 & 1.586 & 469 & $29,5 \%$ \\
& & & \\
235 & 235 & 0 & $0,0 \%$
\end{tabular}


1-0870 Arktisk samarbeidsprogram

1-0950 Hvideruslandsaktiviteter

$\begin{array}{rrrr}1.168 & 1.168 & 0 & 0,0 \% \\ 603 & 603 & 0 & 0,0 \% \\ 215 & 215 & 0 & 0,0 \%\end{array}$

\begin{tabular}{ccccc}
\hline Opdelt på kategorier & $\mathbf{9 . 0 8 8}$ & $\mathbf{9 . 9 6 2}$ & $\mathbf{1 0 0 \%}$ & $\mathbf{1 0 0 \%}$ \\
\hline Projektmidler & 2.798 & 2.798 & $30,8 \%$ & $28,1 \%$ \\
Programlignende aktiviteter & 4.236 & 4.306 & $46,6 \%$ & $43,2 \%$ \\
Institutioner & 2.055 & 2.859 & $22,6 \%$ & $28,7 \%$
\end{tabular}

\section{Samarbejdsministrene}

Budget Budget Difference

Fællesaktiviteter og sekretariatet

Nordisk Ministerråds feellesaktiviteter

1-0410 Föreningarna Nordens Förbund

1-0425 Bidrag til Grönland

1-0435 Generalsekreterarens disponeringsreserv

1-0460 Holdbart Norden

1-1011 Informationsaktiviteter

1-1012 Norden i Fokus

1-1030 Hallo Norden

1-1036 Grænsehindringsråd

1-1050 Tjänstemannautbyte

Ministerrådets sekretariat (NMRS)

1-0180 Ministerrådets sekretariat (NMRS)

\begin{tabular}{rrrr}
$\mathbf{2 0 1 6}$ & \multicolumn{1}{c}{$\mathbf{2 0 1 5}$} & \multicolumn{1}{c}{+ - } & \multicolumn{1}{l}{$\mathbf{\%}$} \\
\hline $\mathbf{1 4 . 2 8 5}$ & $\mathbf{1 4 . 2 8 5}$ & $\mathbf{0}$ & $\mathbf{0 , 0} \%$ \\
& 0 & & \\
3.964 & 3.888 & 76 & $1,9 \%$ \\
433 & 433 & 0 & $0,0 \%$ \\
97 & 97 & 0 & $0,0 \%$ \\
55 & 55 & 0 & $0,0 \%$ \\
406 & 406 & 0 & $0,0 \%$ \\
692 & 692 & 0 & $0,0 \%$ \\
575 & 575 & 0 & $0,0 \%$ \\
896 & 820 & 76 & $9,2 \%$ \\
655 & 655 & 0 & $0,0 \%$ \\
155 & 155 & 0 & $0,0 \%$ \\
10.321 & 10.397 & -76 & $-0,7 \%$ \\
10.321 & 10.397 & -76 & $-0,7 \%$ \\
& & & \\
$\mathbf{1 4 . 2 8 5}$ & $\mathbf{1 4 . 2 8 5}$ & $\mathbf{1 0 0} \%$ & $\mathbf{1 0 0 \%}$ \\
1.728 & 1.728 & $12,1 \%$ & $12,1 \%$ \\
1.706 & 1.630 & $11,9 \%$ & $11,4 \%$ \\
10.321 & 10.397 & $72,3 \%$ & $72,8 \%$ \\
530 & 530 & $3,7 \%$ & $3,7 \%$
\end{tabular}

\begin{tabular}{crrrr}
\hline Opdelt på kategorier & $\mathbf{1 4 . 2 8 5}$ & $\mathbf{1 4 . 2 8 5}$ & $\mathbf{1 0 0 \%}$ & $\mathbf{1 0 0 \%}$ \\
\hline Projektmidler & 1.728 & 1.728 & $12,1 \%$ & $12,1 \%$ \\
Programlignende aktiviteter & 1.706 & 1.630 & $11,9 \%$ & $11,4 \%$ \\
Institutioner & 10.321 & 10.397 & $72,3 \%$ & $72,8 \%$ \\
Organisationsbidrag & 530 & 530 & $3,7 \%$ & $3,7 \%$
\end{tabular}

MR-U

Budget Budget Difference

\begin{tabular}{|c|c|c|c|c|c|}
\hline \multirow{2}{*}{\multicolumn{2}{|c|}{ MR-U }} & \multirow{2}{*}{$\begin{array}{r}\text { Budget } \\
2016\end{array}$} & \multirow{2}{*}{$\begin{array}{r}\text { Budget } \\
2015\end{array}$} & \multicolumn{2}{|c|}{ Difference } \\
\hline & & & & $+/-$ & $\%$ \\
\hline \multirow[t]{3}{*}{ MR-U } & & 30.204 & 30.579 & -375 & $-1,2 \%$ \\
\hline & & & $\mathbf{0}$ & & \\
\hline & Generelle utdannings- og forskningsinnsatser & 440 & 493 & -54 & $-10,9 \%$ \\
\hline \multirow[t]{2}{*}{$2-2505$} & Dispositionsmedel-Utbildning och forskning & 440 & 493 & -54 & $-10,9 \%$ \\
\hline & Politikudvikling m.v. & 2.047 & 2.075 & -28 & $-1,4 \%$ \\
\hline $2-2544$ & Det nordiske sprogsamarbejde & 928 & 940 & -13 & $-1,4 \%$ \\
\hline $2-2553$ & $\begin{array}{l}\text { Politikudvikling, Videnssamfund og IT- } \\
\text { infrastruktur }\end{array}$ & 75 & 76 & -1 & $-1,4 \%$ \\
\hline \multirow[t]{2}{*}{$2-3127$} & Politikudvikling voksnes læring & 1.044 & 1.059 & -14 & $-1,4 \%$ \\
\hline & Mobilitets og netvcerksprogrammer & 10.303 & 10.152 & 151 & $1,5 \%$ \\
\hline $2-2513$ & Nordplus & 9.821 & 10.152 & -332 & $-3,3 \%$ \\
\hline \multirow[t]{2}{*}{$2-2515$} & Nordic Master Programme & 483 & 0 & 483 & \\
\hline & NordForsk & 14.475 & 14.919 & -444 & $-3,0 \%$ \\
\hline \multirow[t]{2}{*}{$2-3100$} & NordForsk & 14.475 & 14.919 & -444 & $-3,0 \%$ \\
\hline & Forskning i øvrigt & 2.939 & 2.939 & 0 & $0,0 \%$ \\
\hline $2-3180$ & Nordisk Institut for Teoretisk Fysik (NORDITA) & 1.207 & 1.207 & 0 & $0,0 \%$ \\
\hline 2-3181 & Nordiska Institutet for Sjörett (NIfS) & 360 & 360 & 0 & $0,0 \%$ \\
\hline 2-3182 & Nordisk Institutt for Asiastudier (NIAS) & 570 & 570 & 0 & $0,0 \%$ \\
\hline 2-3184 & Nordisk vulkanologisk institut (NORDVULK) & 582 & 582 & 0 & $0,0 \%$ \\
\hline 2-3185 & Nordisk Samisk Institutt (NSI) & 220 & 220 & 0 & $0,0 \%$ \\
\hline \multicolumn{2}{|c|}{ Opdelt på kategorier } & 30.204 & 30.579 & $100 \%$ & $100 \%$ \\
\hline
\end{tabular}


Projektmidler

Programlignende aktiviteter

Institutioner
1.442

14.286

14.475
1.510

14.150

14.919
$4,8 \%$

$47,3 \%$

$47,9 \%$
$4,9 \%$

$46,3 \%$

$48,8 \%$

MR-S

Budget Budget Difference

\begin{tabular}{|c|c|c|c|c|c|}
\hline & \multirow{2}{*}{2016} & \multirow{2}{*}{2015} & \\
\hline & & & & $+/-$ & $\%$ \\
\hline \multirow[t]{3}{*}{ MR-S } & & 5.222 & 5.222 & $\mathbf{0}$ & $0,0 \%$ \\
\hline & & & 0 & & \\
\hline & Projektmedel & 2.496 & 2.496 & 0 & $0,0 \%$ \\
\hline $3-4310$ & 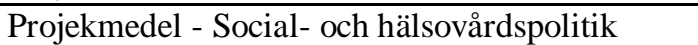 & 612 & 612 & 0 & $0,0 \%$ \\
\hline 3-4311 & $\begin{array}{l}\text { Nordisk helsesamarbejde - opfølgning af Bo } \\
\text { Könbergs rapport }\end{array}$ & 167 & 167 & 0 & $0,0 \%$ \\
\hline $3-4320$ & Rådet för nordiskt samarbete om funktionshinder & 151 & 151 & 0 & $0,0 \%$ \\
\hline $3-4340$ & Nomesko og Nososko & 254 & 254 & 0 & $0,0 \%$ \\
\hline \multirow[t]{2}{*}{ 3-4382 } & NIOM AS - Nordisk institutt for Odontologiske & 1.313 & 1.313 & 0 & $0,0 \%$ \\
\hline & Institutioner & 2.726 & 2.726 & 0 & $0,0 \%$ \\
\hline $3-4380$ & Nordens Välfärdcenter & 2.726 & 2.726 & 0 & $0,0 \%$ \\
\hline \multicolumn{2}{|c|}{ Opdelt på kategorier } & 5.222 & 5.222 & $100 \%$ & $100 \%$ \\
\hline & $\begin{array}{l}\text { Projektmidler } \\
\end{array}$ & 1.183 & 1.183 & $22,7 \%$ & $22,7 \%$ \\
\hline & Programlignende aktiviteter & 1.313 & 1.313 & $25,1 \%$ & $25,1 \%$ \\
\hline & Institutioner & 2.726 & 2.726 & $52,2 \%$ & $52,2 \%$ \\
\hline
\end{tabular}

MR-Kultur

Budget Budget Difference

\begin{tabular}{|c|c|c|c|c|c|}
\hline & & 2016 & 2015 & $+/-$ & $\%$ \\
\hline Sum M & $\overline{\mathrm{R}-\mathrm{K}}$ & 22.405 & 22.405 & $\overline{0}$ & $0,0 \%$ \\
\hline & Generelle kulturinnsatser & 6.733 & 6.204 & 529 & $8,5 \%$ \\
\hline $4-2203$ & Dispositionsmidler Kultur & 126 & 126 & 0 & $0,0 \%$ \\
\hline $4-2205$ & Nordisk kulturfond & 4.603 & 4.603 & 0 & $0,0 \%$ \\
\hline $4-2206$ & Nordisk Råds priser & 515 & 480 & 34 & $7,2 \%$ \\
\hline $4-2208$ & Strategiska satsningar & 1.489 & 994 & 495 & $49,7 \%$ \\
\hline & Barn och unga & 809 & 809 & 0 & $0,0 \%$ \\
\hline $4-2212$ & $\begin{array}{l}\text { Nordisk Børne- og Ungdomskomité } \\
\text { (NORDBUK) }\end{array}$ & 809 & 809 & 0 & $0,0 \%$ \\
\hline & Film och media & 4.141 & 4.700 & -559 & $-11,9 \%$ \\
\hline $4-2221$ & Nordisk computerspilprogram & 0 & 559 & -559 & $-100,0 \%$ \\
\hline $4-2222$ & Nordisk Film- och TV-fond & 3.735 & 3.735 & 0 & $0,0 \%$ \\
\hline & Institutioner & 405 & 405 & 0 & $0,0 \%$ \\
\hline $4-2228$ & NORDICOM & 405 & 405 & 0 & $0,0 \%$ \\
\hline & Konstområdet & 9.856 & 10.188 & -332 & $-3,3 \%$ \\
\hline $4-2251$ & Kultur- og kunstprogrammet & 2.177 & 2.384 & -207 & $-8,7 \%$ \\
\hline $4-2253$ & Nordisk oversættelsesstøtte & 411 & 411 & 0 & $0,0 \%$ \\
\hline $4-2254$ & Nordiskt-baltiskt mobilitetsprogram för Kultur & 1.532 & 1.656 & -124 & $-7,5 \%$ \\
\hline & Nordiska kulturhus (institutioner) & 5.736 & 5.736 & 0 & $0,0 \%$ \\
\hline $4-2270$ & Nordens hus i Reykjavik & 1.191 & 1.191 & 0 & $0,0 \%$ \\
\hline $4-2272$ & Nordens hus på Färöarna & 1.808 & 1.808 & 0 & $0,0 \%$ \\
\hline $4-2274$ & Nordens institut på Åland & 395 & 395 & 0 & $0,0 \%$ \\
\hline $4-2277$ & Nordens institut på Grönland (NAPA) & 847 & 847 & 0 & $0,0 \%$ \\
\hline $4-2548$ & Kulturkontakt Nord & 1.495 & 1.495 & 0 & $0,0 \%$ \\
\hline & Andra kultursatsningar & 866 & 504 & 362 & $71,8 \%$ \\
\hline & Projektmedel och generella stödordningar & 866 & 504 & 362 & $71,8 \%$ \\
\hline $4-2232$ & Prioriterede verksamheter & 362 & 0 & 362 & \\
\hline $4-2234$ & Samisk samarbeid & 504 & 504 & 0 & $0,0 \%$ \\
\hline
\end{tabular}




\begin{tabular}{crrrr}
\hline Opdelt på kategorier & $\mathbf{2 2 . 4 0 5}$ & $\mathbf{2 2 . 4 0 5}$ & $\mathbf{1 0 0 \%}$ & $\mathbf{1 0 0 \%}$ \\
\hline Projektmidler & 1.615 & 1.930 & $7,2 \%$ & $8,6 \%$ \\
Programlignende aktiviteter & 13.783 & 13.830 & $61,5 \%$ & $61,7 \%$ \\
Institutioner & 6.142 & 6.142 & $27,4 \%$ & $27,4 \%$ \\
Organisationsbidrag & 866 & 504 & $3,9 \%$ & $2,2 \%$
\end{tabular}

\begin{tabular}{|c|c|c|c|c|c|}
\hline & MR-FJLS & Budget & Budget & Diffe & \\
\hline & & 2016 & 2015 & $+/-$ & $\%$ \\
\hline$\overline{\text { Sum MI }}$ & R-FJLS & 5.331 & 5.331 & $\mathbf{0}$ & $\mathbf{0 , 0 \%}$ \\
\hline & & & 0 & & \\
\hline & Projektmidler & 122 & 122 & 0 & $0,0 \%$ \\
\hline $5-6420$ & Ny nordisk mad & 122 & 122 & 0 & $0,0 \%$ \\
\hline & Fiskeri & 831 & 831 & 0 & $0,0 \%$ \\
\hline $5-6610$ & Projektmedel - Fiskeri & 831 & 831 & 0 & $0,0 \%$ \\
\hline & Jord- och skovbrug & 3.629 & 3.629 & 0 & $0,0 \%$ \\
\hline & Projektmidler - jordbrug & 159 & 159 & 0 & $0,0 \%$ \\
\hline $5-6510$ & Projektmidler Jordbrug & 49 & 49 & 0 & $0,0 \%$ \\
\hline $5-6520$ & $\begin{array}{l}\text { Nordiskt kontaktorgan för jordbruksforskning } \\
\text { (NKJ) }\end{array}$ & 110 & 110 & 0 & $0,0 \%$ \\
\hline & Institutioner - jordbrug & 2.683 & 2.683 & 0 & $0,0 \%$ \\
\hline $5-6585$ & Nordisk Genressource Center (NordGen) & 2.683 & 2.683 & 0 & $0,0 \%$ \\
\hline & Projektmidler - skovbrug & 786 & 786 & 0 & $0,0 \%$ \\
\hline $5-6310$ & Projektmidler Skovbrug & 41 & 41 & 0 & $0,0 \%$ \\
\hline $5-6581$ & Samnordisk skogsforskning (SNS) & 745 & 745 & 0 & $0,0 \%$ \\
\hline & Levnedsmidler & 750 & 750 & 0 & $0,0 \%$ \\
\hline $5-6810$ & Projektmedel - Levnedsmidler & 676 & 676 & 0 & $0,0 \%$ \\
\hline $5-6830$ & $\begin{array}{l}\text { Nordisk handlingsplan for bedre helse og } \\
\text { livskvalitet }\end{array}$ & 73 & 73 & 0 & $0,0 \%$ \\
\hline Opdelt $_{1}$ & å kategorier & 5.331 & 5.331 & $100 \%$ & $100 \%$ \\
\hline & Projektmidler & 1.671 & 1.671 & $31,3 \%$ & $31,3 \%$ \\
\hline & Programlignende aktiviteter & 977 & 977 & $18,3 \%$ & $18,3 \%$ \\
\hline & Institutioner & 2.683 & 2.683 & $50,3 \%$ & $50,3 \%$ \\
\hline
\end{tabular}

MR-JÄM

Budget Budget Difference

\begin{tabular}{llrrrr} 
& $\mathbf{2 0 1 6}$ & $\mathbf{2 0 1 5}$ & + +- & \multicolumn{1}{c}{$\mathbf{\%}$} \\
\hline MR-Jäm & $\mathbf{1 . 1 8 9}$ & $\mathbf{1 . 1 8 9}$ & $\mathbf{0}$ & $\mathbf{0 , 0 \%}$ \\
& & 1.189 & 1.189 & 0 & $0,0 \%$ \\
\hline 6-4410 & Projektmedel - Jämställdhet & 468 & 468 & 0 & $0,0 \%$ \\
6-4420 & MR-JÄMs stödordning & 381 & 381 & 0 & - \\
6-4480 & Nordisk information för kunskap om kön & 340 & 340 & 0 & $0,0 \%$
\end{tabular}
(NIKK)

\begin{tabular}{crrrr}
\hline Opdelt på kategorier & $\mathbf{1 . 1 8 9}$ & $\mathbf{1 . 1 8 9}$ & $\mathbf{1 0 0 \%}$ & $\mathbf{1 0 0 \%}$ \\
\hline Projektmidler & 849 & 849 & $71,4 \%$ & $71,4 \%$ \\
Programlignende aktiviteter & 340 & 340 & $28,6 \%$ & $28,6 \%$
\end{tabular}

\begin{tabular}{crrrc} 
MR-NER & Budget & Budget & \multicolumn{2}{c}{ Difference } \\
& $\mathbf{2 0 1 6}$ & $\mathbf{2 0 1 5}$ & \multicolumn{1}{c}{+ /- } & \multicolumn{1}{c}{$\mathbf{\%}$} \\
\hline Sum MR-NER & $\mathbf{1 7 . 7 8 6}$ & $\mathbf{1 7 . 7 8 6}$ & $\mathbf{0}$ & $\mathbf{0 , 0 \%}$ \\
Näring & & $\mathbf{0}$ & & \\
Projektmidler - Näring & 12.013 & 12.013 & 0 & $0,0 \%$ \\
\hline
\end{tabular}




\begin{tabular}{llrrrr}
$7-5140$ & Projektmidler Näring & 266 & 266 & 0 & $0,0 \%$ \\
& Institutioner - Näring & 11.747 & 11.747 & 0 & $0,0 \%$ \\
$7-5180$ & Nordisk Innovation (NI) & 9.715 & 9.715 & 0 & $0,0 \%$ \\
$7-5280$ & Nopef & 2.032 & 2.032 & 0 & $0,0 \%$ \\
& Energi & 1.418 & 1.418 & 0 & $0,0 \%$ \\
\hline $7-5141$ & Projektmidler Energi & 554 & 554 & 0 & $0,0 \%$ \\
& Institutioner - Energi & 865 & 865 & 0 & $0,0 \%$ \\
$7-3220$ & Nordisk Energiforskning (NEF) & 865 & 865 & 0 & $0,0 \%$ \\
& Regional & 4.355 & 4.355 & 0 & $0,0 \%$ \\
\hline $7-5143$ & Impl. af samarbetsprogram, demografi, & 713 & 713 & 0 & $0,0 \%$ \\
& arbetsgrupper och projekmedel - Regional & & & & \\
$7-5151$ & NORA & 888 & 888 & 0 & $0,0 \%$ \\
$7-5160$ & Grenseregionalt samarbeid & 1.245 & 1.245 & 0 & $0,0 \%$ \\
& Institutioner - Regional & 1.509 & 1.509 & 0 & $0,0 \%$ \\
$7-6180$ & Nordregio & 1.509 & 1.509 & 0 & $0,0 \%$ \\
\hline Opdelt på kategorier & $\mathbf{1 7 . 7 8 6}$ & $\mathbf{1 7 . 7 8 6}$ & $\mathbf{1 0 0 \%}$ & $\mathbf{1 0 0 \%}$ \\
\hline & Projektmidler & 1.533 & 1.533 & $8,6 \%$ & $8,6 \%$ \\
& Programlignende aktiviteter & 1.245 & 1.245 & $7,0 \%$ & $7,0 \%$ \\
& Institutioner & 14.121 & 14.121 & $79,4 \%$ & $79,4 \%$ \\
& Organisationsbidrag & 888 & 888 & $5,0 \%$ & $5,0 \%$
\end{tabular}

\begin{tabular}{llrrrr} 
MR-Miljø & Budget & Budget & \multicolumn{2}{c}{ Difference } \\
& $\mathbf{2 0 1 6}$ & $\mathbf{2 0 1 5}$ & \multicolumn{1}{c}{+ - } & \multicolumn{1}{c}{$\mathbf{0}$} \\
\hline MR-Miljø & $\mathbf{5 . 9 1 9}$ & $\mathbf{5 . 9 1 9}$ & $\mathbf{0}$ & $\mathbf{0 , 0} \%$ \\
& & $\mathbf{0}$ & & \\
$8-3310$ & Dispositionsmidler - Miljø & 568 & 768 & -200 & $-26,0 \%$ \\
$8-3311$ Miljøsektorens arbejdsgrupper & 3.231 & 3.030 & 201 & $6,6 \%$ \\
$8-3312$ Nordisk Råds miljøpris & 80 & 82 & -1 & - \\
$8-3320$ & NEFCOS Miljøudviklingsfond & 1.477 & 1.477 & 0 & $0,0 \%$ \\
8-6720 & SVANEN - Nordisk miljömärkning & 563 & 563 & 0 & $0,0 \%$ \\
\hline Opdelt på kategorier & & & & \\
\hline$\quad$ Projektmidler & $\mathbf{5 . 9 1 9}$ & $\mathbf{5 . 8 3 8}$ & $\mathbf{1 0 0 \%}$ & $\mathbf{1 0 0 \%}$ \\
$\quad$ Programlignende aktiviteter & 568 & 768 & $9,6 \%$ & $13,2 \%$ \\
& Organisationsbidrag & 4.788 & 4.506 & $80,9 \%$ & $77,2 \%$ \\
\end{tabular}

\begin{tabular}{llrrrr} 
& MR-Arbetsliv & Budget & Budget & \multicolumn{2}{c}{ Difference } \\
& $\mathbf{2 0 1 6}$ & $\mathbf{2 0 1 5}$ & \multicolumn{1}{c}{+ - } & \multicolumn{1}{c}{$\mathbf{0}$} \\
\hline MR-A & & $\mathbf{1 . 8 2 7}$ & $\mathbf{1 . 8 2 7}$ & $\mathbf{0}$ & $\mathbf{0 , 0} \%$ \\
& & 0 & & \\
& Projektmedel & 1.376 & 1.376 & 0 & $0,0 \%$ \\
\hline $9-4110$ & Projektmidler i øvrigt - Arbejdsliv & 122 & 122 & 0 & $0,0 \%$ \\
$9-4111$ & Arbejdsliv faste udvalg & 614 & 614 & 0 & $0,0 \%$ \\
$9-4120$ & Nordjobb & 424 & 424 & 0 & $0,0 \%$ \\
$9-4130$ & Kommunikation om arbejdsliv & 216 & 216 & 0 & $0,0 \%$ \\
& Institutioner & 452 & 452 & 0 & $0,0 \%$ \\
\hline 9-4180 & Institut för vidareutb.inom arbetsmiljö (NIVA) & 452 & 452 & 0 & $0,0 \%$ \\
& & & & \\
\hline Opdelt på kategorier & $\mathbf{1 . 8 2 7}$ & $\mathbf{1 . 8 2 7}$ & $\mathbf{1 0 0 \%}$ & $\mathbf{1 0 0 \%}$ \\
\hline & 338 & 338 & $18,5 \%$ & $18,5 \%$ \\
& Projektmidler & 1.038 & 1.038 & $56,8 \%$ & $56,8 \%$ \\
& Programlignende aktiviteter & 452 & 452 & $24,7 \%$ & $24,7 \%$
\end{tabular}




\begin{tabular}{|c|c|c|c|c|c|}
\hline & MR-Finans & Budget & Budget & Diffe & ice \\
\hline & & 2016 & 2015 & $+/-$ & $\%$ \\
\hline MR-Fina & & 243 & 243 & $\mathbf{0}$ & $0,0 \%$ \\
\hline $10-5210$ & Projektmedel- Ekonomi och finanspolitik & 243 & 243 & 0 & $0,0 \%$ \\
\hline Opdelt p & i kategorier & 243 & 243 & $100 \%$ & $100 \%$ \\
\hline & Projektmidler & 243 & 243 & $100 \%$ & $100 \%$ \\
\hline & MR-Lag & Budget & Budget & Diffe & ice \\
\hline & & 2016 & 2015 & $+/-$ & $\%$ \\
\hline$\overline{\text { MR-Lag }}$ & & 185 & 185 & $\mathbf{0}$ & $0,0 \%$ \\
\hline $11-7110$ & Projektmedel - Lagstiftning & 185 & 185 & 0 & $0,0 \%$ \\
\hline & Opdelt på katgorier & 185 & 185 & $100 \%$ & $100 \%$ \\
\hline & Projektmidler & 185 & 185 & $100 \%$ & $100 \%$ \\
\hline
\end{tabular}


SAMMENSTILLING AF BUDGET 2016 OG 2015 (løbende priser, TEUR)

\begin{tabular}{|c|c|c|c|c|c|}
\hline & \multirow{2}{*}{$\begin{array}{r}\text { Budget } \\
2016\end{array}$} & \multirow{2}{*}{$\begin{array}{r}\text { Budget } \\
2015\end{array}$} & \multicolumn{2}{|c|}{ Difference } \\
\hline & & & & $+/-$ & $\%$ \\
\hline \multirow[t]{6}{*}{1.} & MR Samarbejdsministrene & 33.343 & 34.217 & -874 & $-2,6 \%$ \\
\hline & $\begin{array}{ll}\text { a. } & \text { Prioriteringsbudgettet }\end{array}$ & 9.970 & 9.970 & 0 & $0,0 \%$ \\
\hline & $\begin{array}{l}\text { b. Internationalt } \\
\text { samarbejde }\end{array}$ & 9.088 & 9.962 & -874 & $-8,8 \%$ \\
\hline & i. Heraf kontorerne* & 2.055 & 2.859 & -804 & $-28,1 \%$ \\
\hline & c. Nordisk Ministerråds fællesaktiviteter og sekretariatet & 14.285 & 14.285 & 0 & $0,0 \%$ \\
\hline & i. Heraf sekretariatet (NMRS) & 10.321 & 10.397 & -76 & $-0,7 \%$ \\
\hline \multirow[t]{6}{*}{2.} & MR Uddannelse og forskning & 30.204 & 30.579 & -375 & $-1,2 \%$ \\
\hline & $\begin{array}{ll}\text { a. } & \text { Generelle forsknings- og uddannelsesinitiativer }\end{array}$ & 440 & 493 & -54 & $-10,9 \%$ \\
\hline & b. Politikudvikling mv. & 2.047 & 2.075 & -28 & $-1,4 \%$ \\
\hline & c. Mobilitets- og netværksprogrammer & 10.303 & 10.152 & 151 & $1,5 \%$ \\
\hline & d. NordForsk (institution) & 14.475 & 14.919 & -444 & $-3,0 \%$ \\
\hline & e. Forskning i øvrigt & 2.939 & 2.939 & 0 & $0,0 \%$ \\
\hline \multirow[t]{2}{*}{3.} & MR Social- og Helsepolitik & 5.222 & 5.222 & $\mathbf{0}$ & $\mathbf{0 , 0 \%}$ \\
\hline & i. Heraf Nordens Välfärdcenter (institution) & 2.726 & 2.726 & 0 & $0,0 \%$ \\
\hline \multirow[t]{8}{*}{4.} & MR Kulturpolitik & 22.405 & 22.405 & $\mathbf{0}$ & $\mathbf{0 , 0 \%}$ \\
\hline & a. $\quad$ Generelle kultursatsninger & 6.733 & 6.204 & 529 & $8,5 \%$ \\
\hline & b. Børn og Unge & 809 & 809 & 0 & $0,0 \%$ \\
\hline & c. Film og Media & 4.141 & 4.700 & -559 & $-11,9 \%$ \\
\hline & i. Heraf NORDICOM (institution) & 405 & 405 & 0 & $0,0 \%$ \\
\hline & d. Kunstområdet & 9.856 & 10.188 & -332 & $-3,3 \%$ \\
\hline & i. Heraf Nordiske Kulturhuse (institutioner) & 5.736 & 5.736 & 0 & $0,0 \%$ \\
\hline & e. Andre kultursatsninger & 866 & 504 & 362 & $71,8 \%$ \\
\hline \multirow[t]{6}{*}{5.} & MR Fiskeri og havbrug, Jordbrug, Levnedsmidler og Skovbrug & 5.331 & 5.331 & $\mathbf{0}$ & $\mathbf{0 , 0 \%}$ \\
\hline & a. $\quad$ Fiskeri & 831 & 831 & 0 & $0,0 \%$ \\
\hline & b. Jordbrug & 2.842 & 2.842 & 0 & $0,0 \%$ \\
\hline & i. Heraf NordGen (institution) & 2.683 & 2.683 & 0 & $0,0 \%$ \\
\hline & c. Levnedsmidler & 871 & 871 & 0 & $0,0 \%$ \\
\hline & d. Skovbrug & 5.867 & 5.867 & 0 & $0,0 \%$ \\
\hline 6. & MR Ligestilling & 1.189 & 1.189 & $\mathbf{0}$ & $\mathbf{0 , 0 \%}$ \\
\hline \multirow[t]{7}{*}{7.} & MR Närings-, Energi- og Regionalpolitik & $\mathbf{1 7 . 7 8 6}$ & 17.786 & $\mathbf{0}$ & $\mathbf{0 , 0 \%}$ \\
\hline & a. $\quad$ Näring & 12.013 & 12.013 & 0 & $0,0 \%$ \\
\hline & i. Heraf Nordisk Innovation (institution) & 9.715 & 9.715 & 0 & $0,0 \%$ \\
\hline & b. Energi & 1.418 & 1.418 & 0 & $0,0 \%$ \\
\hline & i. Heraf Nordisk Energiforskning (institution) & 865 & 865 & 0 & $0,0 \%$ \\
\hline & c. Regional & 4.355 & 4.355 & 0 & $0,0 \%$ \\
\hline & i. Heraf Nordregion (institution) & 1.509 & 1.509 & 0 & $0,0 \%$ \\
\hline 8. & MR Miljø & 5.919 & 5.919 & $\mathbf{0}$ & $0,0 \%$ \\
\hline & MR Arbejdsmarkedspolitik & 1.827 & 1.827 & $\mathbf{0}$ & $\mathbf{0 , 0 \%}$ \\
\hline & i. Heraf NIVA (institution) & 452 & 452 & 0 & $0,0 \%$ \\
\hline 10. & $\begin{array}{l}\text { MR Ekonomi og } \\
\text { Finanspolitik }\end{array}$ & 243 & 243 & $\mathbf{0}$ & $0,0 \%$ \\
\hline & MR Lagstiftning & 185 & 185 & $\mathbf{0}$ & $0,0 \%$ \\
\hline Tote & alt nordisk budget & 123.655 & 124.904 & -1.249 & $-1,0 \%$ \\
\hline
\end{tabular}

*Ministerrådets kontorer i Estland, Letland, Litauen og Nordvestrusland 
Bilag 2 - Status 27.052015 på budgetpostniveau

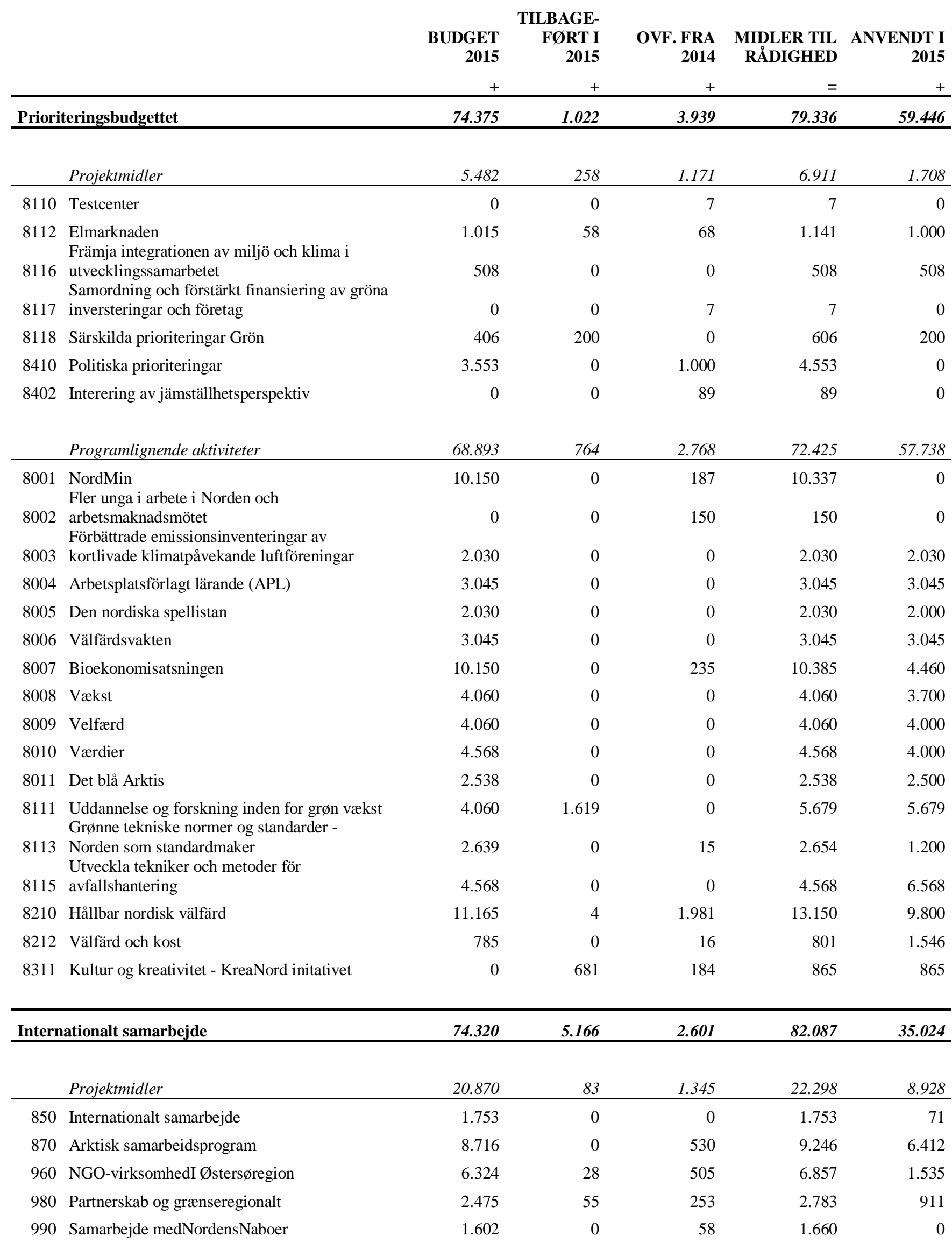




\begin{tabular}{|c|c|c|c|c|c|c|}
\hline & Programlignende aktiviteter & 32.120 & 5.083 & 1.099 & 38.302 & 5.150 \\
\hline 820 & Kunskapsuppbyggning och Nätver & 27.622 & 4.945 & 1.017 & 33.584 & 5.133 \\
\hline 950 & EHU/Hviderusland & 4.498 & 138 & 82 & 4.718 & 16 \\
\hline & Institutioner & 21.330 & 0 & 156 & 21.486 & 20.946 \\
\hline 810 & Ministerrådets kontorerI Baltikum & 11.834 & 0 & 0 & 11.834 & 11.800 \\
\hline 970 & Ministerrådets kontorerINordvest Rusland & 9.496 & 0 & 156 & 9.652 & 9.146 \\
\hline
\end{tabular}

\begin{tabular}{|c|c|c|c|c|c|c|}
\hline \multicolumn{2}{|c|}{ Samarbejdsministrene } & \multirow{2}{*}{$\begin{array}{l}29.003 \\
12.889\end{array}$} & \multirow{2}{*}{$\begin{array}{l}999 \\
298 \\
\end{array}$} & \multirow{2}{*}{$\begin{array}{r}1.030 \\
500 \\
\end{array}$} & \multirow{2}{*}{$\begin{array}{l}31.032 \\
13.687\end{array}$} & \multirow{2}{*}{$\begin{array}{r}24.738 \\
8.057 \\
\end{array}$} \\
\hline & Projektmidler & & & & & \\
\hline 435 & Generalsekreterarens disponeringsreserv & 412 & 0 & 56 & 468 & 123 \\
\hline 460 & Holdbart Norden & 3.026 & 298 & 336 & 3.660 & 684 \\
\hline 1011 & Informationsaktiviteter & 5.162 & 0 & -48 & 5.114 & 2.961 \\
\hline 1012 & Norden i Fokus & 4.289 & 0 & 156 & 4.445 & 4.289 \\
\hline & Programlignende aktiviteter & 12.162 & 701 & 530 & 13.393 & 12.729 \\
\hline 1030 & Hallo Norden & 6.120 & 54 & 0 & 6.174 & 6.174 \\
\hline 1036 & Grænsehindringsråd & 4.889 & 329 & 331 & 5.549 & 4.888 \\
\hline 1050 & Tjänstemannautbyte & 1.153 & 318 & 198 & 1.669 & 1.667 \\
\hline & Organisationsbidrag & 3.952 & 0 & 0 & 3.952 & 3.952 \\
\hline 410 & Föreningarna Nordens Förbund & 3.227 & 0 & 0 & 3.227 & 3.227 \\
\hline 425 & Bidrag til Västnorden & 725 & 0 & 0 & 725 & 725 \\
\hline
\end{tabular}

\section{Aktiviteter med selvstændigt regnskab}

\begin{tabular}{clllll} 
I alt & 77.560 & 0 & 0 & 77.560 & 35.988 \\
\hline \multirow{2}{*}{180 Ministerrådets sekretariat (NMRS) } & 77.560 & 0 & 0 & 77.560
\end{tabular}

\begin{tabular}{|c|c|c|c|c|c|c|}
\hline MR-U & & 228.116 & 14 & 1.575 & 229.704 & 266.419 \\
\hline & Projektmidler & 11.263 & 14 & 1.039 & 12.316 & 15.348 \\
\hline 2505 & Dispositionsmedel-Utbildning och forskning & 3.680 & 14 & 70 & 3.763 & 929 \\
\hline 2544 & Det nordiske Sprogsamarbejde & 7.015 & 0 & 580 & 7.595 & 7.015 \\
\hline 2553 & Politikudvikling, Videnssamfund & 568 & 0 & 0 & 568 & 0 \\
\hline 2560 & Ad hoc arbejdsrupper på prioriterede områder & 0 & 0 & 389 & 389 & 389 \\
\hline & Programlignende aktiviteter & 105.557 & 0 & 536 & 106.093 & 105.406 \\
\hline 2513 & Nordplus rammeprogram & 75.735 & 0 & 194 & 75.929 & 75.584 \\
\hline 2545 & Nordenundervisning i utlandet & 0 & 0 & 74 & 74 & 0 \\
\hline 3127 & Politikudvikling voksnes læring & 7.898 & 0 & 0 & 7.898 & 7.898 \\
\hline 3140 & Nordisk komitè for Bioetikk & 0 & 0 & 27 & 27 & 0 \\
\hline 3180 & NordiskInstitut for Teoretisk & 9.002 & 0 & 0 & 9.002 & 9.002 \\
\hline
\end{tabular}


3181 Nordiska Institutet for Sjöre

3182 NordiskInstitutt for Asiastud

3184 Nordisk vulkanologiskInstitut

3185 Nordisk SamiskInstitutt (NSI)

$\begin{array}{ll}2.683 & 0 \\ 4.253 & 0 \\ 4.344 & 0 \\ 1.642 & 0\end{array}$

\section{7}

91

93

0
2.740

4.344

4.437

1.642

111.296

111.296
2.683

4.253

4.344

1.642

\begin{tabular}{rlllll} 
Institutioner & 111.296 & 0 & 0 & 111.296 & 145.664 \\
\hline \multirow{2}{*}{3100 NordForsk } & 111.296 & 0 & 0 & 111.296 & 111.296
\end{tabular}

\begin{tabular}{|c|c|c|c|c|c|c|}
\hline \multicolumn{2}{|l|}{ MR-S } & \multirow{2}{*}{$\begin{array}{r}38.956 \\
8.826 \\
\end{array}$} & \multirow{2}{*}{$\begin{array}{l}1.000 \\
1.000 \\
\end{array}$} & \multirow{2}{*}{$\begin{array}{r}864 \\
859 \\
\end{array}$} & \multirow{2}{*}{$\begin{array}{r}40.820 \\
10.685 \\
\end{array}$} & \multirow{2}{*}{$\begin{array}{r}36.708 \\
6.578 \\
\end{array}$} \\
\hline & Projektmidler & & & & & \\
\hline 4310 & Projekmedel - Social- och hälse & 4.568 & 1.000 & 859 & 6.427 & 4.686 \\
\hline 4320 & Nordiska Handikappolitiska Råd & 1.123 & 0 & 0 & 1.123 & 0 \\
\hline 4340 & $\begin{array}{l}\text { Nomesko ogNososko } \\
\text { Nordisk helsesamarbejde - opfølgning af Bo }\end{array}$ & 1.892 & 0 & 0 & 1.892 & 1.892 \\
\hline 4311 & Könbergs rapport & 1.243 & 0 & 0 & 1.243 & 0 \\
\hline & Programlignende aktiviteter & 9.795 & 0 & 6 & 9.801 & 9.795 \\
\hline 4382 & NordiskInstitutt for Odontolo & 9.795 & 0 & 6 & 9.801 & 9.795 \\
\hline & Institutioner & 20.335 & 0 & 0 & 20.335 & 20.335 \\
\hline 4380 & Nordisk Velfærdscenter & 20.335 & 0 & 0 & 20.335 & 20.335 \\
\hline
\end{tabular}

\begin{tabular}{|c|c|c|c|c|c|}
\hline MR-Kultur & 167.143 & 1.306 & 1.689 & 170.139 & 152.712 \\
\hline
\end{tabular}

\begin{tabular}{llrrrrr} 
& Projektmidler & 8.359 & 956 & 1.181 & 10.496 & 7.432 \\
\hline 2203 & Dispostionsmidler Kultur & 941 & 7 & 81 & 1.029 & 358 \\
2208 & Strategiska satsningar & 7.418 & 949 & 1.100 & 9.467 & 7.074
\end{tabular}

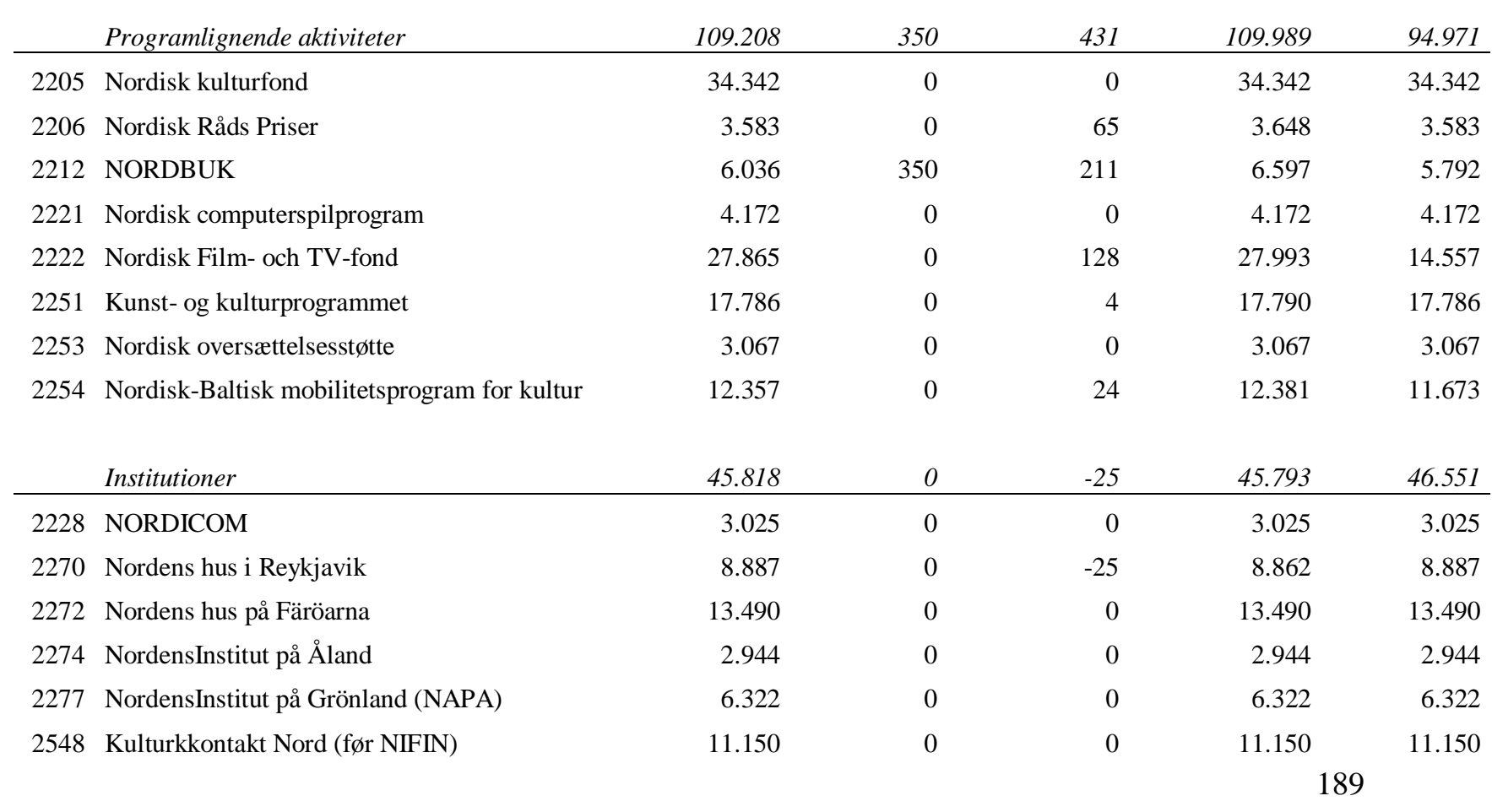




\begin{tabular}{rllllll} 
Organisationsbidrag & 3.758 & 0 & 102 & 3.860 & 3.758 \\
\hline 2234 & Samisk samarbeid & 3.758 & 0 & 102 & 3.860
\end{tabular}

\begin{tabular}{|c|c|c|c|c|c|c|}
\hline \multicolumn{2}{|c|}{ MR-FJSL } & \multirow{2}{*}{$\begin{array}{l}39.769 \\
12.466 \\
\end{array}$} & \multirow{2}{*}{$\begin{array}{l}0 \\
0 \\
0\end{array}$} & \multirow{2}{*}{$\begin{array}{l}593 \\
593 \\
\end{array}$} & \multirow{2}{*}{$\begin{array}{l}40.362 \\
13.059 \\
\end{array}$} & \multirow{2}{*}{$\begin{array}{r}38.654 \\
11.351 \\
\end{array}$} \\
\hline & Projektmidler & & & & & \\
\hline 6310 & Projektmidler Skovbrug & 306 & 0 & 150 & 456 & 240 \\
\hline 6510 & Projektmidler Jordbrug & 369 & 0 & 81 & 450 & 4 \\
\hline 6610 & Projektmedel - Fiskeri & 6.198 & 0 & 28 & 6.226 & 6.036 \\
\hline 6810 & $\begin{array}{l}\text { Projektmedel - Levnedsmidler } \\
\text { Nordisk handlignsplan for bedre helse og }\end{array}$ & 5.046 & 0 & 265 & 5.311 & 4.523 \\
\hline \multirow[t]{2}{*}{6830} & livskvalitet & 547 & 0 & 70 & 617 & 547 \\
\hline & Programlignende aktiviteter & 7.287 & 0 & 0 & 7.287 & 7.287 \\
\hline 6420 & $\begin{array}{l}\text { Ny nordisk Mad } \\
\text { Nordiskt kontaktorgan för jordbruksforskning }\end{array}$ & 907 & 0 & 0 & 907 & 907 \\
\hline 6520 & $(\mathrm{NKJ})$ & 819 & 0 & 0 & 819 & 819 \\
\hline \multirow[t]{2}{*}{6581} & Samnordisk skogsforskning (SNS9 & 5.561 & 0 & 0 & 5.561 & 5.561 \\
\hline & Institutioner & 20.016 & 0 & 0 & 20.016 & 20.016 \\
\hline 6585 & Nordisk Genressource Center (NORDGEN) & 20.016 & 0 & 0 & 20.016 & 20.016 \\
\hline \multicolumn{2}{|c|}{ MR-Ligestilling } & 8.873 & 503 & 6 & 9.382 & 8.825 \\
\hline & Projektmidler & 6.335 & 503 & 6 & 6.844 & 6.287 \\
\hline 4410 & Projektmedel - Jämställdhet & 3.493 & 503 & 6 & 4.002 & 3.445 \\
\hline \multirow[t]{2}{*}{4420} & MR-JÄMs stödordning & 2.842 & 0 & 0 & 2.842 & 2.842 \\
\hline & Programlignende aktiviteter & 2.538 & 0 & 0 & 2.538 & 2.538 \\
\hline 4480 & NordisktInstitutt for kvinde for kjønn (NIKK) & 2.538 & 0 & 0 & 2.538 & 2.538 \\
\hline MR-N & ER & 132.686 & 830 & 2.346 & 135.862 & 127.906 \\
\hline
\end{tabular}

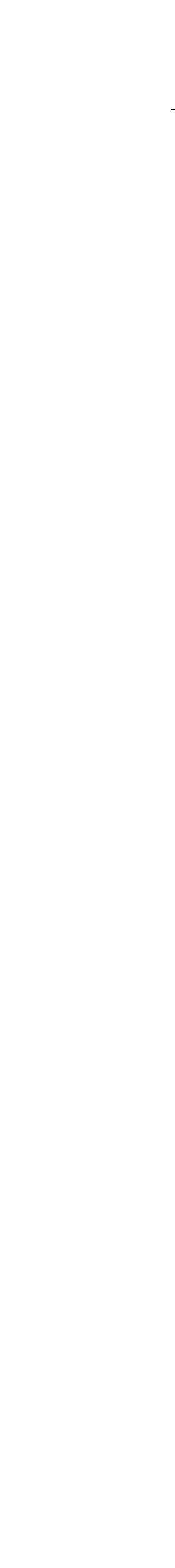

\begin{tabular}{|c|c|c|c|c|c|c|}
\hline & Projektmidler & 11.436 & 830 & 873 & 13.139 & 6.851 \\
\hline 5140 & Projektmidler Næring & 1.986 & 762 & 190 & 2.938 & 857 \\
\hline 5141 & Projektmidler Energi & 4.130 & 68 & 151 & 4.349 & 878 \\
\hline 5143 & Projektmidler Regional & 5.320 & 0 & 532 & 5.852 & 5.117 \\
\hline & Programlignende aktiviteter & 24.449 & 0 & 1.143 & 25.592 & 24.254 \\
\hline 5160 & Grænsekomiteer & 9.287 & 0 & 1.143 & 10.430 & 9.092 \\
\hline 5280 & Nordiska Projektexportfonden & 15.162 & 0 & 0 & 15.162 & 15.162 \\
\hline & Institutioner & 90.177 & 0 & 330 & 90.507 & 90.177 \\
\hline 3220 & Nordisk Energiforskning (NEF) & 6.452 & 0 & 0 & 6.452 & 6.452 \\
\hline 5180 & NordiskInnovationsCenter (NIC & 72.471 & 0 & 0 & 72.471 & 72.471 \\
\hline 6180 & Nordregio & 11.254 & 0 & 330 & 11.584 & 11.254 \\
\hline
\end{tabular}




\begin{tabular}{|c|c|c|c|c|c|c|}
\hline & Organisationsbidrag & 6.624 & 0 & 0 & 6.624 & 6.624 \\
\hline 5151 & NORA & 6.624 & 0 & 0 & 6.624 & 6.624 \\
\hline \multicolumn{2}{|c|}{ MR-Miljø } & 44.157 & 23 & 629 & 44.809 & 40.879 \\
\hline & Projektmidler & 5.732 & 23 & 194 & 5.949 & 2.797 \\
\hline \multirow[t]{2}{*}{3310} & Projektmedel - Miljö & 5.732 & 23 & 194 & 5.949 & 2.797 \\
\hline & Programlignende aktiviteter & 34.226 & 0 & 435 & 34.661 & 33.883 \\
\hline 3311 & Miljøsektorens arbejdsgrupper & 22.601 & 0 & 414 & 23.015 & 22.267 \\
\hline 3320 & NEFCOS Miljøudviklingsfond & 11.016 & 0 & 21 & 11.037 & 11.016 \\
\hline \multirow[t]{2}{*}{3312} & Nordisk Råds miljøpris & 609 & 0 & 0 & 609 & 600 \\
\hline & Organisationsbidrag & 4.199 & 0 & 0 & 4.199 & 4.199 \\
\hline 6720 & SVANEN -Nordisk miljömärkning & 4.199 & 0 & 0 & 4.199 & 4.199 \\
\hline \multicolumn{2}{|l|}{ MR-A } & 13.632 & 25 & 883 & 14.540 & 10.277 \\
\hline & Projektmidler & 2.519 & 3 & 57 & 2.579 & 590 \\
\hline 4110 & Prosjektmedel - Arbejdsliv & 907 & 3 & 0 & 910 & 590 \\
\hline \multirow[t]{2}{*}{4130} & Informationsprojektet & 1.612 & 0 & 57 & 1.669 & 0 \\
\hline & Programlignende aktiviteter & 7.743 & 22 & 826 & 8.591 & 6.317 \\
\hline 4120 & Nordjobb & 3.160 & 0 & 78 & 3.238 & 3.238 \\
\hline \multirow[t]{2}{*}{4111} & Arbejdeliv - faste udvalg & 4.583 & 22 & 748 & 5.353 & 3.079 \\
\hline & Institutioner & 3.370 & 0 & 0 & 3.370 & 3.370 \\
\hline 4180 & Institut för vidareutb.inom arbetsliv & 3.370 & 0 & 0 & 3.370 & 3.370 \\
\hline \multicolumn{2}{|c|}{ MR-Finans } & 1.810 & 30 & 67 & 1.907 & 1.050 \\
\hline & Projektmidler & 1.810 & 30 & 67 & 1.907 & 1.050 \\
\hline 5210 & Projektmedel- Ekonomi och fina & 1.810 .000 & 30.000 & 66.747 & 1.906 .747 & 1.050 .000 \\
\hline \multicolumn{2}{|c|}{ MR-Lov } & 1.382 & 498 & 209 & 2.089 & 585 \\
\hline & Projektmidler & 1.382 & 498 & 209 & 2.089 & 585 \\
\hline 7110 & Projektmedel - Lagstiftning & 1.382 & 498 & 209 & 2.089 & 585 \\
\hline Total & & 931.782 & 12.956 & 16.431 & 883.610 & 757.806 \\
\hline
\end{tabular}




\section{Bilag 3 - Økonomiske delegeringsregler i Nordisk Ministerråd}

På samarbejdsministrenes møde den 26. februar 2007 vedtog man en tilføjelse til Nordisk Ministerråds økonomireglement, hvorefter hvert enkelt ministerråd skal fastsætte egne retningslinjer for den økonomiske dispositionsret. Nedenstående tabel viser delegeringsreglerne for de forskellige ministerråd.

\begin{tabular}{|c|c|c|}
\hline $\begin{array}{l}\text { Beslutningsorgan } \\
\text { MR/EK }\end{array}$ & Beløbsgrcense & $\begin{array}{l}\text { Andre disponenter end } \\
\text { EK/MR og eventuel } \\
\text { beløbsgrcense }\end{array}$ \\
\hline MR-Kultur ${ }^{1)}$ & $>=1 \mathrm{MDKK}$ & \\
\hline EK-Kultur & $<1 \mathrm{MDKK}$ & \\
\hline MR-Jäm ${ }^{2)}$ & $>=1 \mathrm{MDKK}$ & \\
\hline EK-Jäm & $<1$ MDKK & \\
\hline MR-Lag $^{3)}$ & $>=1 \mathrm{MDKK}$ & \\
\hline EK-Lag & $<1 \mathrm{MDKK}$ & \\
\hline \multicolumn{3}{|l|}{ MR-U ${ }^{3)}$} \\
\hline EK-U & Alle beslutninger uanset beløb & \\
\hline \multicolumn{3}{|l|}{ MR-A } \\
\hline EK-A & Alle beslutninger uanset beløb & \\
\hline \multicolumn{3}{|l|}{ MR-NER $^{4)}$} \\
\hline EK-N, EK-E og EK-R & Alle beslutninger uanset beløb & \\
\hline \multicolumn{3}{|l|}{ MR-S ${ }^{5)}$} \\
\hline EK-S & Alle beslutninger uanset beløb & \\
\hline \multicolumn{3}{|l|}{ MR-Finans } \\
\hline EK-Finans & Alle beslutninger uanset beløb & \\
\hline \multicolumn{3}{|l|}{ MR-M $^{5)}$} \\
\hline EK-M & Alle beslutninger uanset beløb & \\
\hline \multicolumn{3}{|l|}{ MR-FJLS ${ }^{3)}$} \\
\hline EK-FJLS & Alle beslutninger uanset beløb. & \\
\hline MR-SAM $^{6)}$ & $>1 \mathrm{MDKK}$ & \\
\hline NSK & $=<1 \mathrm{MDKK}$ & \\
\hline
\end{tabular}

1) Beslutningen indeholder endvidere en bestemmelse om at Generelsekretæren kan bevilge indtil 500 TDKK fra sektorens dispositionsmidler.

2) Beslutningen indeholder endvidere en bestemmelse om at Generalsekretæren kan bevilge indtil 300 TDKK af sektorens midler

3) Beslutningen indeholder endvidere en bestemmelse om at Generalsekretæren kan bevilge indtil 750 TDKK af sektorens midler.

4) Beslutningen indeholder endvidere en bestemmelse om at Generalsekretæren kan bevilge indtil 50 TDKK per gang fra sektorens midler og bevilge totalt 100 TDKK på hvert af områderne næring, energi og regional.

5) Beslutningen indeholder endvidere en bestemmelse om at Generalsekretæren kan bevilge indtil 250 TDKK fra sektorens dispositionsmidler. 6) Gælder for beslutninger under Holdbart Norden 1-0460. På Holdbart Norden er der endvidere taget beslutning om at Generalsekretæren kan disponere indtil 300 TDKK (NSK beslutning 10/10). På området Internationalt samarbejde varierer beløbsgrænserne på budgetposter. Der henvises til MR-SAM beslutninger 42/08 og 39/09. 


\section{Bilag 4 - Förteckning över förkortningar}

\begin{tabular}{|c|c|}
\hline AAG & Association of American Geographics \\
\hline $\mathrm{ABA}$ & Active biodiversity assessment \\
\hline ACAP & Arctic Contaminants Action Programme \\
\hline ADI & Asian Dynamics Initiative - Köpenhamns Universitets Asiensatsning \\
\hline AMAP & Arctic monitoring and assessment programme \\
\hline BAT & Best available techniques \\
\hline BDF & Baltic Development Forum \\
\hline BEAC & Barents Euro-.Arctic Council \\
\hline BHSF & Barents Hot Spot Facility \\
\hline BSAP & Baltic Sea Action Plan (HELCOM) \\
\hline CAR & Climate Action Reserve \\
\hline CBD & Convention of Biological Diversity \\
\hline CBSS & Council of the Baltic Sea States \\
\hline CCAC & Climate and Clean Air Coalition \\
\hline CEN & European Committee for Standardization \\
\hline CFP & The Common Fisheries Policy (EU) \\
\hline CLRTAP & Convention on Long-Range Transboundary Air Pollution \\
\hline CNARC & China Nordic Arctic Research Center \\
\hline CSD & Commission on Sustainable Development \\
\hline CSR & Corporate Social Responsibility \\
\hline CSW & Commission of the Status of Women \\
\hline EES & European Evaluation Society \\
\hline EFINORD & North European Office of the European Forest Institute \\
\hline EFTA & European Free Trade Association \\
\hline EHU & European Humanities University \\
\hline EMG & Elmarknadsgruppen \\
\hline ENIC & European Network of Information Centres in the European Region \\
\hline ERA & European Research Area \\
\hline ERC & European Research Council \\
\hline ESPON & European Observation Network for Territorial Development and Cohesion \\
\hline EU & Europeiska Unionen \\
\hline EØS & Europeisk Østersøsamarbejde \\
\hline FAO DADIS & Food and Agriculture Organization \\
\hline FN & Förenta Nationerna \\
\hline FNF & Föreningarna Nordens Förbund \\
\hline GREECO & Territorial Potential for a greener Economy \\
\hline HELCOM & Helsingfors Kommissionen \\
\hline ICES & International Council for Exploration of the Sea \\
\hline ICT & Information and Communication Technology \\
\hline IEA & International Energy Agency \\
\hline IED & Industrial Emission Directive (Miljö) \\
\hline INC & Intergovernmental Negotiating Committée (ang. kvicksilverkonvention) \\
\hline IUFRO & International Union on Forest Research Organizations \\
\hline
\end{tabular}




\begin{tabular}{|c|c|}
\hline KAW & Knut och Alice Wallenbergs stiftelse för forskning med hög vetenskaplig potential \\
\hline KKN & KulturKontaktNord \\
\hline KU & Köpenhamns Universitet \\
\hline LPA & Lärande på arbetsplatsen \\
\hline LTU & Luleå tekniska universitet \\
\hline MR-A & Ministerrådet för Arbetsliv \\
\hline MR-Finans & Ministerrådet för Ekonomi- och Finanspolitik \\
\hline MR-FJLS & Ministerrådet för Fiskeri, Havsbruk, Jordbruk, Livsmedel och Skogsbruk \\
\hline MR-Jäm & Ministerrådet för Jämställdhet \\
\hline MR-K & Ministerrådet för Kultur \\
\hline MR-Lag & Ministerrådet för Lagstiftning \\
\hline MR-M & Ministerrådet för Miljö \\
\hline MR-NER & Ministerrådet för Näring, Energi och Regionalpolitik \\
\hline MR-S & Ministerrådet för Social och Hälsopolitik \\
\hline MR-SAM & Samarbetsministrarna \\
\hline MR-U & Ministerrådet för Utbildning \\
\hline NAPA & Nordens Institut på Grönland \\
\hline NEF & Nordisk Energiforskning \\
\hline NEFCO & Nordic Environment Finance Corporation \\
\hline NEPR & Nordic Economic Policy Review \\
\hline NETP & Nordic Energy Technology Perspectives \\
\hline NI & Nordisk Innovation \\
\hline NGI & Nordic Game Institute \\
\hline NGO & Non Government Organisation \\
\hline NHV & Nordiska Hälsovårdshögskolan \\
\hline NIAS & Nordens Institut för Asienstudier \\
\hline NIF & Norden i Fokus \\
\hline NIFIN & Nordens Institut i Finland \\
\hline NIfS & Nordiskt Institut för Sjörätt \\
\hline NIKK & Nordisk Institutt for kunnskap om kjønn \\
\hline NIOM & Nordisk Institutt for Odontologiske Materialer \\
\hline NIPÅ & Nordens Institut på Åland \\
\hline NIVA & Nordiska Institutionen för vidareutveckling inom arbetsmiljöområdet \\
\hline NJC & Nordiskt Journalist Center \\
\hline NKG & Nordiska kemikaliegruppen \\
\hline NKJ & Nordiskt Kontaktorgan för jordbruksforskning \\
\hline NLH & Nordens Hus på Färöarna \\
\hline NLP & Nordic Play List \\
\hline NMF & Nordisk arbetsgrupp för Livsmedelsförvaltning och Konsumentinformation \\
\hline NMR & Nordiska Ministerrådet \\
\hline NMRS & Nordiska Ministerrådets Sekretariat \\
\hline NMN & Nordiska Miljömärkningsnämnden \\
\hline NNC & Nordic Nias Council \\
\hline NNM & Ny Nordisk Mat \\
\hline NNR & Nordic Nutrition Recommandation \\
\hline NOMESKO & Nordisk Medicinalstatistisk Kommitté \\
\hline NOMEX & Nordic Music Export Program \\
\hline
\end{tabular}




\begin{tabular}{|c|c|}
\hline NOPEF & Nordiska Projektexport Fonden \\
\hline NOPUS & Nordiskt Utbildningsprogram for Social Service \\
\hline NORA & Nordiskt Atlantsamarbete \\
\hline NOREY & Nordens Hus i Reykjavik \\
\hline NORDBUK & Nordisk Barn och Ungdomskommitté \\
\hline NordGen & Nordisk Genresurs Center \\
\hline NORDICOM & Nordiskt Informationscenter för Medie- och Kommunikationsforskning \\
\hline NORDITA & Nordiskt Institut for Teoretisk Fysik \\
\hline Nordregio & Nordisk Center för Regional Utveckling \\
\hline NORDVULK & Nordiskt Vulkanologiskt Institut \\
\hline NOSOSKO & Nordisk Social-Statistisk Kommitté \\
\hline NPI & Nordic Partnership Initiative \\
\hline NSI & Nordiskt Samiskt Institut \\
\hline NSK & Nordisk Samarbetskommitté \\
\hline NSU & Nordiskt Sommaruniversitet \\
\hline NVC & Nordens Välfärdscenter \\
\hline NVL & Nätverk för vuxnas lärande \\
\hline OECD & Organisation for Economic Cooperation and Development \\
\hline OMNIS & Företag specialiserat inom webhosting, domainregistrering och webservices \\
\hline ONN & $\begin{array}{l}\text { Nätverk för nordiska organisationer } \\
\text { The convention for the Protection of the Marine Environment in the North East }\end{array}$ \\
\hline OSPAR & Atlantic (OSlo and PARis commission) \\
\hline $\mathrm{PhD}$ & Doctor of Philosophy \\
\hline PIIAC & Program for the International Assessment of Adult Competencies \\
\hline PIRLS & Progress in International Reading Literacy Study \\
\hline PISA & Programme for International Student Assessment \\
\hline POP & Persistant Organic Pollutants ( marine miljö) \\
\hline SLCP & Short lived Climate Pollutants \\
\hline SNS & Samnordisk Skogsforskning \\
\hline SME-bolag & Små och mellanstora företag \\
\hline SVANEN & Nordiskt miljömärke \\
\hline SVL & Nordiskt samarbete om vuxnas lärande \\
\hline TAC & Total allowable catches (Fiskeri) \\
\hline TALIS & Teaching and Learning International Study \\
\hline TBO & Nordisk arbetsgrupp för glesbefolkade områden \\
\hline TFBCM & Task force on Black Carbon and Methane \\
\hline TFEIP & Task force on Emissions, Inventories and Projections \\
\hline TIMSS & Trends in International Mathematics and Science Study \\
\hline UNEP & United Nations Environment Programme \\
\hline UNECE & United Nations Economic Commission for Europe \\
\hline UNFCCC & United Nations Framework Convention on Climate Change \\
\hline WEEE & Waste electrical and electronic Equipment \\
\hline WHO & World Health Organization \\
\hline ÄK/EK-xxx & Ämbetsmannakommitté /Embedsmandskommitté \\
\hline
\end{tabular}

